\title{
Climate Change in the Hudson Bay Complex: Opportunities and Vulnerabilities for the Port of Churchill's Marine Operations
}

\author{
J. Andrews, D. Babb, M. McKernan, B. Horton and D. Barber \\ Centre for Earth Observation Science \\ University of Manitoba
}

\section{A part of Transport Canada's}

Network of EXpertise on Transportation in Arctic Waters (NEXTAW) 


\section{Climate Change in the Hudson Bay Complex:}

\section{Opportunities and Vulnerabilities for the Port of Churchill's Marine Operations}

A product of Transport Canada's

Network of EXpertise on Transportation in Arctic Waters (NEXTAW)

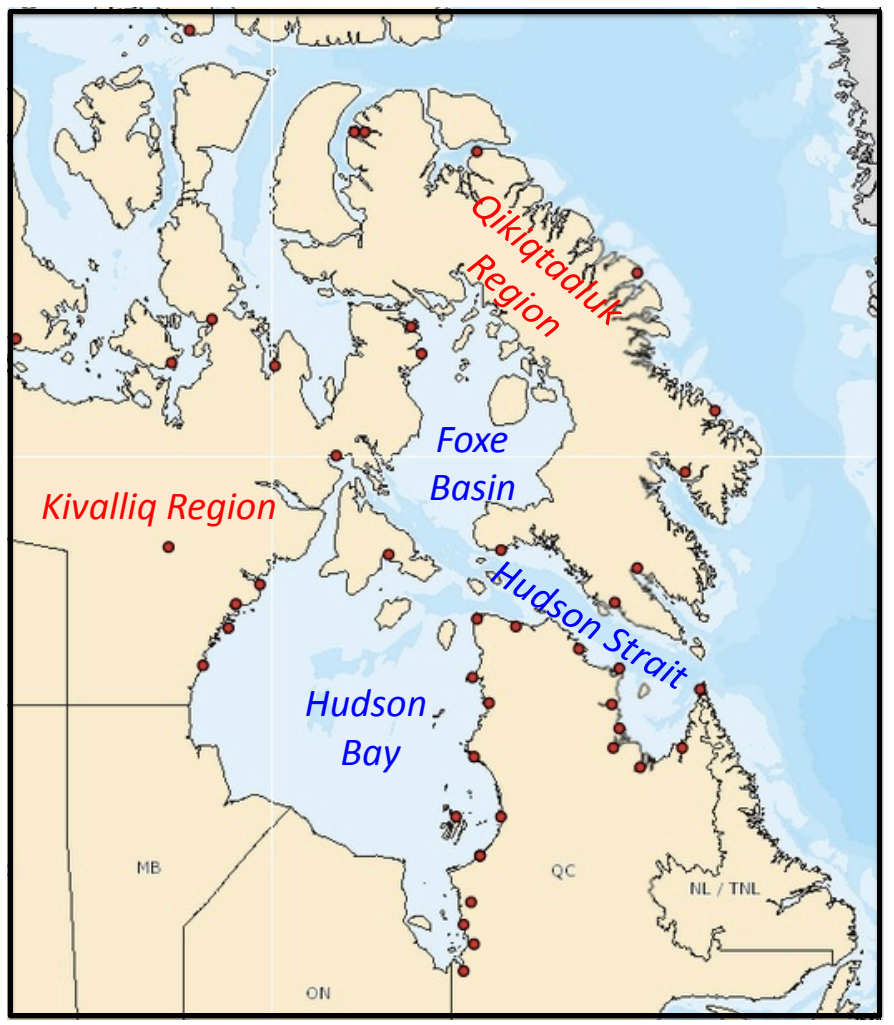

The Hudson Bay Complex: Hudson Bay, Hudson Strait, and Foxe Basin.

Map modified from Arctic Voyage Planning Guide (2013).

Authors:

Jonathan Andrews, David Babb, Mike McKernan, Brian Horton, and Dr. David Barber

The Centre for Earth Observation Science

University of Manitoba

Winnipeg, MB.

Corresponding author: Jonathan Andrews, Jonathan.Andrews@umanitoba.ca 


\section{About this Assessment}

\section{Context and Goals}

This climate-impact assessment was completed by researchers at the University of Manitoba's Centre for Earth Observation Science (CEOS) with financial support from Transport Canada. This work is one component of a broader CEOS-Transport Canada partnership running from 2014-2016, which is a product of Transport Canada's Network of EXpertise on Transportation in Arctic Waters (NEXTAW) program. NEXTAW is part of Transport Canada's Northern Transportation Adaptation Initiative.

The motivation for this project at CEOS and Transport Canada stems from an awareness of the significant environmental changes occurring in the Canadian Arctic and a shared desire to better understand these changes and the impact they may have on marine transportation in the area.

This assessment examines the impact of climate change in Hudson Bay, Hudson Strait, and Foxe Basin, and considers the resultant vulnerabilities and opportunities for the Port of Churchill's marine operations extending to 2030 and 2050. Changes in sea ice and their consequences for shipping routes are of particular interest. The Port of Churchill's land-based infrastructure and operations are not examined in this assessment.

This document's primary audience is those parties with a vested interested in marine transportation in the Hudson Bay Complex. This includes the Port of Churchill's central stakeholders, such as OmniTRAX Canada, Manitoba Infrastructure and Transportation, and Transport Canada, as well as community and industry members from around the Complex. More generally, it is our intention that this document will be useful to all those interested in the intersection between Climate Change and marine transportation in the Canadian Arctic.

\section{Methods}

The content in this document was largely produced by an extensive review of the relevant scientific literature, by examining the ongoing and recently published research at CEOS, and by interviews with representatives of the Port of Churchill's central stakeholders. Some content was also produced by novel analysis of climate data; the authors conducted data analysis to examine trends in air temperature, precipitation, and wind strengths in the Hudson Bay Complex.

Copies of this publication are available on the CEOS website at http://umanitoba.ca/faculties/environment/departments/ceos/research/NEXTAW.html 


\section{About the Authors and Contributors}

\section{Authors:}

Jonathan Andrews, B.Sc.: A Masters student at the University of Manitoba's Centre for Earth Observation Science (CEOS) studying the implications of climate change for northern marine transportation.

David Babb, M.Sc.: A Research Associate at CEOS studying sea ice dynamics and thermodynamics throughout the Arctic and the implications of a changing ice pack on northern marine transportation.

Mike McKernan, M.Sc., MES, P.Biol: A Research Associate at CEOS and Principal of MLi3 Inc., an environmental consultancy specializing in regulatory process compliance; environmental planning, impact assessment and licensing/permitting; and corporate environmental due diligence.

Brian Horton, M.Sc.: Formerly a Research Associate with CEOS. Currently a Research Project Coordinator with the Northern Climate Exchange, Yukon Research Centre in Whitehorse, YK.

Dr. David Barber: A Distinguished Professor and Associate Dean (Research) in the Clayton H. Riddell Faculty of Earth, Environment and Resources at the University of Manitoba. Dr. Barber holds a Canada Research Chair (Tier 1) within Arctic System Science.

\section{Contributors:}

We are grateful for the excellent guidance and support kindly provided by the contributors listed below:

- Jeff McEachern, Vice President of Operations for the Hudson Bay Port Company (formerly Executive Director of the Churchill Gateway Development Corporation)

- Erica Vido, Director of Transportation Systems Planning and Development, Manitoba Infrastructure and Transportation.

- Dr. Adolf Ng, Professor of Maritime Transport \& Logistics Management at the University of Manitoba and Associate Director of the University of Manitoba Transport Institute.

- François Gaudreau, Management Assistant of Sales and Operations, Nunavut Sealink \& Supply Inc.

- $\quad$ Cory Young, Chief Officer of the Town of Churchill.

- Sinclair Harrison, President of the Hudson Bay Route Association.

- Jan Andersen, Port Captain for Norden Tankers and Bulkers USA.

- Pauline Gerrard, Institutional Development Coordinator, International Institute for Sustainable Development.

- Claire Hornby, Research Associate with CEOS

- Kerri Warner, Formerly a Research Associate with CEOS, Currently a Physical Scientist, Research, with the Meteorological Service of Canada

- $\quad$ Dr. Jennifer Lukovich, Research Associate with CEOS 


\section{Table of Contents:}

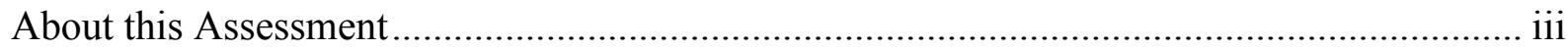

About the Authors and Contributors .....................................................................................

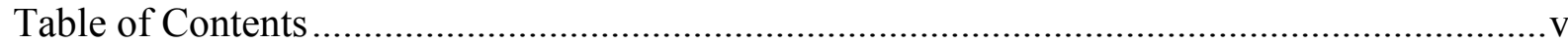

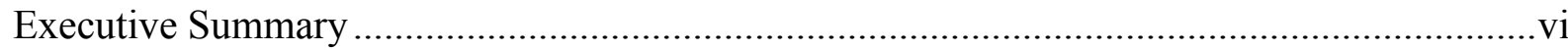

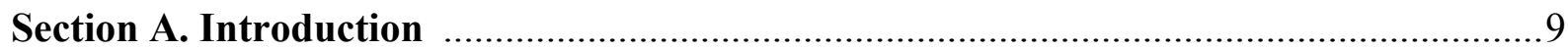

1. In Brief: The Port of Churchill and Key Stakeholders................................................

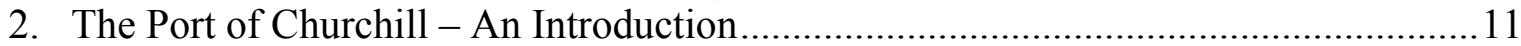

3. The Port of Churchill - Shipping Infrastructure and Operations ................................. 16

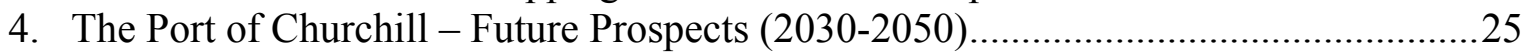

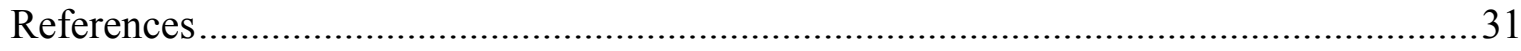

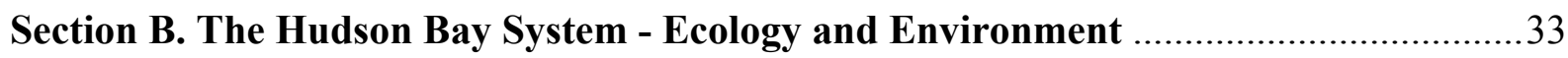

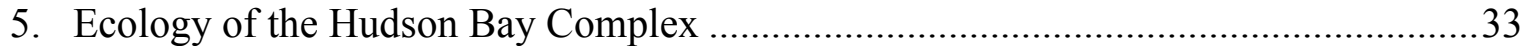

6. Environment of the Hudson Bay Complex: Climate-related trends, variability, and

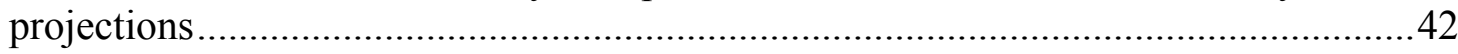

Section C. Climate-related Vulnerabilities and Opportunities..................................... 102

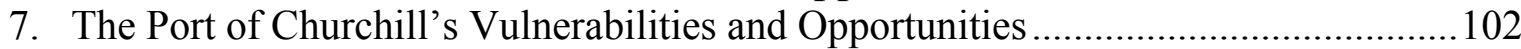

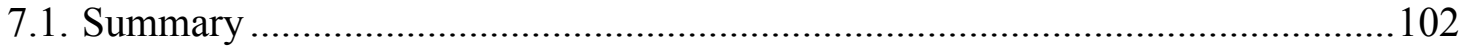

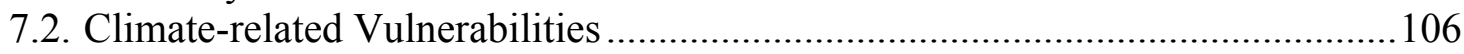

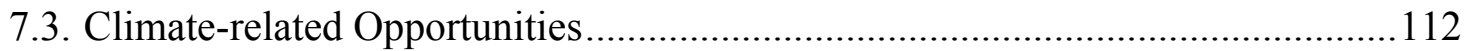

7.4. The Hudson Bay Complex's Ecological Vulnerabilities to Shipping Activity ...119

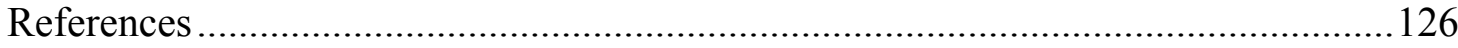

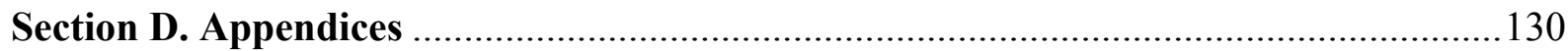

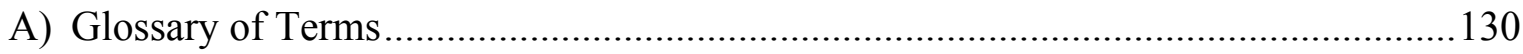




\section{Executive Summary}

This climate-impact assessment examines the impact of climate change in Hudson Bay, Hudson Strait, and Foxe Basin, and considers the resultant vulnerabilities and opportunities for the Port of Churchill's marine operations extending to 2030 and 2050. Changes in sea ice and their consequences for shipping routes are of particular interest.

\section{The Port of Churchill}

The Port of Churchill is an international port located on the southwest coast of Hudson Bay in Churchill, Manitoba. The Port's primary freight is Canadian grain, and between 1997 and 2014 roughly 500,000 tonnes of grain were exported to international destinations each year. For context, this export volume represents roughly two percent of the grain exported from Canada each year. In addition to grain, the Port of Churchill handles roughly 10,000 tonnes of marine resupply freight per year, destined for the Nunavut region of Kivalliq.

Shipping vessels travelling to the Port of Churchill pass through Hudson Strait and Hudson Bay, and occasionally Foxe Basin; these three water bodies are collectively referred to as the Hudson Bay Complex. The waters of the Hudson Bay Complex undergo a complete freeze and thaw cycle each year. As a result, the Port of Churchill is only accessible to shipping traffic during an open water season that currently runs from roughly mid-July to early November. The length of the Port's actual shipping season has typically run from early August to late October in recent years.

Essentially all grain-carrying vessels visiting the Port of Churchill are non ice-strengthened bulk carriers and it unlikely that ice-strengthened vessels or icebreakers will be used in the near future to enable shipping in heavier ice conditions. The vessels carrying re-supply freight from the Port are ice-strengthened. Canadian regulations governing shipping in Arctic waters restrict non icestrengthened vessels travelling to the Port of Churchill to a shipping season of July $20^{\text {th }}$ to October $31^{\text {st }}$. Shipping with non ice-strengthened vessels is possible outside of these dates, but only if ice conditions are relatively mild and extra ice-related requirements are met by vessel operators. These requirements often make shipping outside of the July $20^{\text {th }}$ to October $31^{\text {st }}$ season more challenging and expensive, as do the premiums added to the already relatively expensive marine insurance required for shipping in Arctic waters.

The Port and Town of Churchill are accessible by ship, plane, and rail, but not by road. Manitoba's highway system only extends as far as Thompson, which is roughly four-hundred kilometres south of Churchill; however, Churchill is connected to the towns of Thompson and Le Pas, and the rest of the North American rail and highway system, by the Hudson Bay Railway. Both the Hudson Bay Railway and the Port of Churchill are owned and operated by OmniTRAX Canada, which is an affiliate of OmniTRAX, Inc., a Broe Group company from the United States. The privately-owned Port is an important contributor to the economy of the Town of Churchill, which has a population of roughly 900 people and counts the Port as one of its four economic pillars, alongside tourism, healthcare, and research and education. 
The Port of Churchill and the Hudson Bay Railway were listed for sale by OmniTRAX Inc., in December 2015. Even without a change in ownership, change may be coming to the Port of Churchill in the near future. The Port is striving to increase its annual grain shipments and may begin to ship potash or oil on a large scale within the time frame of the analysis in this assessment (i.e. by 2030 or 2050). Marine re-supply activity through the Port could also increase in response to the growth of communities and industry in the Hudson Bay Complex. Moreover, these potential changes at the Port are occurring alongside dramatic changes in the climate and environment of the Hudson Bay Complex.

\section{The ecology of the Hudson Bay Complex}

The Port of Churchill's marine operations interact with a host of ecologically, biologically, and culturally significant ecosystems and species. The Complex contains a wide range of unique and sensitive marine ecosystems, including thirteen areas that have been labelled as Ecologically and Biologically Significant Areas (EBSAs) by the Government of Canada's Department of Fisheries and Oceans. The Port of Churchill is situated within the Southwestern Hudson Bay Estuaries EBSA, which is characterized by the world's largest Beluga aggregations, Polar Bear denning sites, and highly productive and diverse coastal waters. The main shipping route through the Complex to the Port traverses two EBSAs in Hudson Strait. The Strait is an important migratory corridor for wildlife and is also home to colonies and aggregations of an assortment of marine mammals and seabirds, many of which are of cultural importance to the local indigenous people. The ecological influences of the Port's shipping operations will be directly felt in the areas that are home to shipping traffic and may extend into other, more distant parts of the Complex.

\section{Climate and sea ice in the Hudson Bay Complex: trends and projections}

The Complex is a highly dynamic environment undergoing rapid change. Surface air temperatures in the Complex typically range from seasonal averages of -30 to $-10^{\circ} \mathrm{C}$ in the winter and 0 to $12^{\circ} \mathrm{C}$ in the summer. These temperatures are warming rapidly in all areas of the Complex, particularly in the fall. This warming is expected to continue into the future, with projections calling for an increase of nearly $1{ }^{\circ} \mathrm{C}$ per decade in the annual average temperature of the Complex between 2012 and 2061.

At present the Hudson Bay Complex is largely free of sea ice during August, September, and October, with the longest open water season occurring in Hudson Strait, followed by Hudson Bay, and Foxe Basin. The open water season has grown significantly in all three regions of the Complex since 1980, with break-up occurring earlier and freeze-up moving later into the fall. Climate projections predict that these changes will continue at pace or more rapidly in the future.

Long term sea level in the Complex declined significantly due to isostatic rebound until as recently as 1985 , but the influence of sea level rise produced by climate change appears to have balanced out this decline in some areas and slowed it in others. Short-term, seasonal sea level at Churchill appears to vary in response to river discharge and hydroelectric regulation and both these factors may change in the future, although the direction and magnitude of their effect on seasonal sea level variation is as yet unclear. 
Storms are most frequent, intense, and lengthy in the Complex during the "storm season" of August to December. This "storm season" appears to be extending into the winter in response to longer open water conditions. Although there is little evidence of change in monthly average precipitation at Churchill since 1970, there was an observable shift towards increasing daily precipitation earlier in the shipping season and lower daily precipitation later in the season. Freezing precipitation, meanwhile, is responding in highly variable fashion to changes in climate while the frequencies of fog and blowing snow are largely declining in the Complex. Finally, average winds are strongest in the fall in the Hudson Bay Complex and many areas of the Complex, including Churchill, have seen an increase in wind speeds since 1970.

\section{The Port of Churchill's climate-related vulnerabilities}

The Port of Churchill's shipping operations are vulnerable to adverse weather in the Hudson Bay Complex and these operations may be rendered more vulnerable by a lack of hydrographic data for the Complex and by the Coast Guard's apparently limited Search and Rescue capability in the area.

Adverse weather that could impact the Port's operations includes high winds, precipitation, and storms. Wind may currently interfere with Port operations during roughly half of the days in the shipping season and projections for the future suggest that wind disruption could become more common. As for precipitation, roughly half the days of the shipping season pass without measurable precipitation and there is a general tendency towards an increasing risk of precipitation disruption in the early months of the season and a declining risk of precipitation disruption in the later part of the season. Finally, the current storm regime may disrupt shipping related operations at the Port and within the Complex for 10 to 18 days of the shipping season and there do not appear to be projections for significant change to this regime.

\section{The Port of Churchill's climate-related opportunities}

The Port of Churchill's shipping season averaged roughly 11 weeks between 1997 and 2014. The open water period along the direct shipping route to the Port of Churchill averaged 16.3 weeks in length from 1980-2010. The open water period along the shipping route grew by an average of 4.2 weeks for 1996-2010 versus 1980-1995 and is projected to extend beyond a minimum of 18.4 weeks by 2030 and 20.4 weeks by 2050 . In fact, model projections are calling for an open water season of closer to 30 weeks by 2050. Climate-driven changes to sea ice in the Complex appear to present an opportunity for a significantly longer shipping season for the Port of Churchill by 2030 and 2050. Meanwhile, current and projected environmental and economic conditions in the Hudson Bay Complex are highly favourable for an expansion of the Port of Churchill's re-supply activity.

\section{The Hudson Bay Complex's ecological vulnerabilities to Port of Churchill operations}

The ecosystems of the Hudson Bay Complex are vulnerable to a variety of stressors produced by Port and shipping operations. The most pressing vulnerabilities include pollution, disturbance of marine mammals, and the introduction of invasive species. With regard to pollution, the Hudson Bay Complex appears to be particularly vulnerable to a potential oil spill. 


\section{Section A. Introduction}

\section{In Brief: The Port of Churchill and Key Stakeholders}

The following section briefly introduces the Port of Churchill and some of the Port's key stakeholders (indicated in bold). More information about the Port and stakeholders is provided throughout the text but brief introductions have been placed here to provide background information and context.

The Port of Churchill is an international port located on the southwest coast of Hudson Bay in Churchill, Manitoba. The Port's primary freight is Canadian grain, and between 1997 and 2014 an average of 500,000 tonnes of grain were exported to international destinations each year over the course of the shipping season. The shipping season is typically 11 weeks long and is constrained by sea ice (J. McEachern, personal communication, November $\left.18^{\text {th }}, 2014\right)$. In addition to grain, the Port of Churchill also handles roughly 10,000 tonnes of re-supply freight each year. This freight is destined for communities in Nunavut and may consist of a broad range of cargo, including non-perishable food items, building material, housing supplies, mining equipment, automobiles, and fuel oil (F. Gaudreau, personal communication, March 20, 2015).

The Town of Churchill has a permanent resident population of roughly 860 people but this population grows substantially during the warmer months and the town has infrastructure for 2000-3000 people. The economy of the Town of Churchill is currently based on three main economic pillars: the Port of Churchill, healthcare, and tourism. Moreover, efforts are underway to strengthen and develop the Town's fourth economic pillar: research and education (C. Young, personal communication, February $\left.26^{\text {th }}, 2015\right)$.

The Port and Town of Churchill are accessible by ship, plane, or rail. Manitoba's provincial highway system only extends to the north as far as the towns of Thompson and The Pas, well south of Churchill. Churchill is connected to Thompson, The Pas, and the rest of the North American rail and highway system by the Hudson Bay Railway. Both the Port of Churchill and the Hudson Bay Railway are owned and operated by OmniTRAX Canada, which is an affiliate of OmniTRAX, Inc., a Broe Group company from the United States (J. McEachern, personal communication, February 18, 2015). However, OmniTRAX Inc. listed both the Port of Churchill and the Hudson Bay Railway for sale in December of 2015 (Winnipeg Free Press, 2015).

OmniTRAX Inc.'s current holdings and operations along the Hudson Bay Railway and at the Port of Churchill have been subdivided into several companies: The Hudson Bay Port Company, The Hudson Bay Railway Company, Churchill Marine Tank Farm, which owns and operates the fuel-storage facility at the Port, OmniTRAX Canada Freight Services, which conducts loading and unloading of freight cargo in Thompson and Churchill, and finally Nunavut Connections, which provides the stevedoring services at the Port of Churchill $(J$. McEachern, personal communication, February 18, 2015).

Other important stakeholders in the Port of Churchill include the Churchill Gateway Development Corporation, Churchill Arctic Port Canada, the Hudson Bay Route Association, 
Nunavut Sealink and Supply Inc., and the provincial, territorial, and federal governments of Manitoba, Nunavut, and Canada, respectively. Several of these stakeholders are discussed in more detail below:

The Churchill Gateway Development Corporation (CGDC) was a public-private partnership created by the provincial and federal governments in partnership with OmniTRAX in 2003 to market the Port of Churchill. The CGDC's operations appear to have ended: federal funding for the corporation ended in 2014 and the Government of Manitoba introduced legislation in November 2013 to create a new marketing corporation called Churchill Arctic Port Canada that appears designed to replace the CGDC. However, there has been no public disclosure of any further development of Churchill Arctic Port Canada beyond the initial legislation, despite the fact that the CGDC closed operations on March $31^{\text {st }}$ of 2015 (Cash, 2015).

The Hudson Bay Route Association (HBRA) is an organization that advocates for the use, maintenance, and further development of the Port of Churchill and the Hudson Bay Railway on behalf of the individuals and municipalities involved in producing the grain and other freight that moves through the Port (S. Harrison, personal communication, March 12, 2015).

Nunavut Sealink and Supply Inc. (NSSI) is the shipping company that conducts Arctic community re-supply from the Port of Churchill. The Government of Nunavut (GN) coordinates the re-supply of dry cargo for government departments, communities, and residents in Nunavut (Transport Canada, 2010b). In 2012, the GN awarded NSSI a 5-year contract to provide the resupply shipping services to nearly all communities of Nunavut; this contract includes an option for extension. Most of NSSI's vessels sail from Montreal, but the company currently loads freight at the Port of Churchill at least 3 times each year to re-supply the Nunavut region of Kivalliq. NSSI loads an average of roughly 10,000 tonnes of re-supply freight at the Port each year (F. Gaudreau, personal communication, March 20, 2015).

Prior to 1997 the Port of Churchill was owned by the Government of Canada. The Port has been owned by OmniTRAX, Inc. since then but both the federal government and the Government of Manitoba are highly invested in the Port's current operations. Together, these two governments have committed to a cumulative investment of roughly \$133 million in the Port and the Hudson Bay Railway between 1997 and 2017 (Meredith and Norquay, 2013). 


\section{The Port of Churchill - An Introduction}

The Port of Churchill, located in northern Manitoba on the western side of Hudson Bay, is Canada's only deepwater Arctic port. The Port has been owned and operated by the Hudson Bay Port Company, a subsidiary of OmniTRAX, Inc., since 1997. Prior to 1997 the Port was owned by the Government of Canada (Meredith and Norquay, 2013). Despite the federal government's divestment in 1997, the governments of both Manitoba and Canada continue to provide financial support for the ongoing operations and development at the Port. In recent years there has been talk amongst the Port of Churchill's stakeholders about developing the Port into a central player in the trade industries of the Arctic and central Canada (Meredith and Norquay, 2013). However, the Port's future course is highly uncertain at present; in December 2015 the Port of Churchill and the Hudson Bay Railway were listed for sale (Winnipeg Free Press, 2015).

The Port of Churchill is located at $58^{\circ} \mathrm{N}$ on the Churchill River estuary, on a point that extends to the northwest from the town of Churchill with the estuary on one side and Hudson Bay on the other. Hudson Bay is often grouped with Foxe Basin and Hudson Strait for scientific analysis and discussion and in this assessment the three ocean regions are collectively referred to as the Hudson Bay Complex. The entirety of the Hudson Bay Complex undergoes a complete freeze and thaw cycle each year.

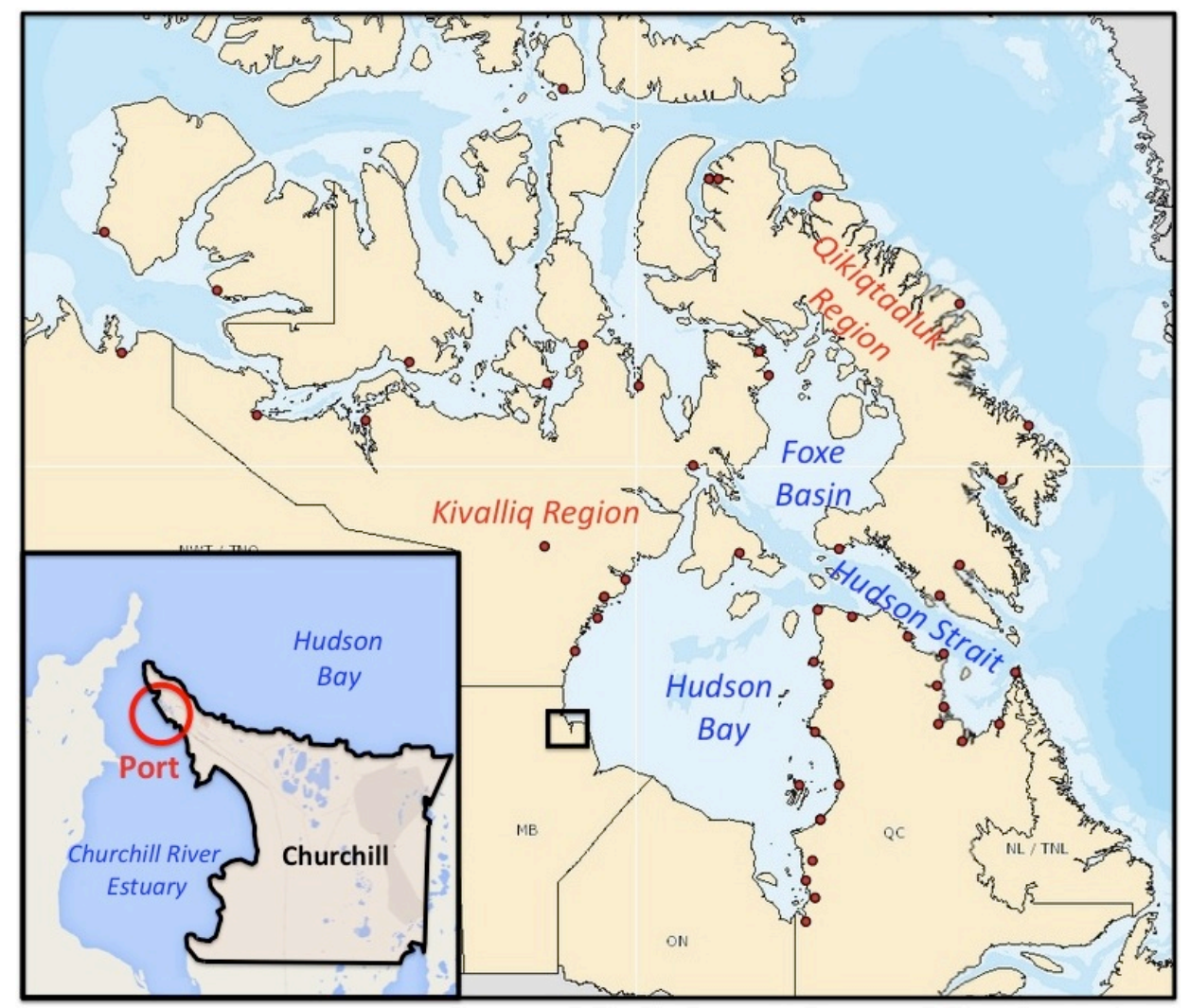

Figure 2.1: The Port of Churchill and the Hudson Bay Complex. Kivalliq and Qikiqtaaluk are regions of Nunavut. The Hudson Bay Complex is composed of Hudson Bay, Foxe Basin, and Hudson Strait. Red dots on the map indicate communities. Map from Arctic Voyage Planning Guide (2013). 
The regions and towns of the Hudson Bay Complex are home to relatively few people and possess little marine infrastructure. A 2011 census recorded a population of roughly 32,000 in Nunavut, with 9,000 living in Kivalliq, and 17,000 in Qikiqtaaluk (Statistics Canada, 2014). According to the same 2011 census, the Quebec coastline in the Hudson Bay Complex is home to roughly 12,000 people, with roughly 5000 on the coast of Hudson Bay and 7,000 on the coast of Hudson Strait (Statistics Canada, 2014). With the exception of the Port of Churchill, the marine infrastructure in the Complex is either extremely basic or nonexistent. Very few of the towns in the area are equipped with any port infrastructure and re-supply freight is unloaded on the beach in nearly all locations (F. Gaudreau, personal communication, March 20, 2015).

\section{Key characteristics of the Port's marine operations}

The Port has 4 loading berths, including one tanker berth. The berths are capable of accommodating "Panamax" class vessels (vessels with approximately 70,000 tonne capacity). The Port is equipped to handle a variety of cargo, including grain, food items, construction supplies, fuel, and hazardous goods (Port of Churchill, n.d.). It is important to note that the shipping vessels moving freight from the Port of Churchill are all owned by third parties, not by OmniTRAX, Inc., or any of its subsidiaries (J. McEachern, personal communication, February 18, 2014). More information on the Port's shipping infrastructure is provided in Section 3.

In addition to the supply chain logistics that affect the shipping season of all Canadian ports, the Port of Churchill's shipping season is also influenced by the formation and breakup of sea ice. Put very briefly, open water historically occurs in the Hudson Bay Complex from July to early November (Hochheim and Barber, 2014). Between 2009 and 2014 the Port of Churchill operated a shipping season of roughly 11 weeks, typically running from early August to late October ( $J$. McEachern, personal communication, November 18, 2014).

Since OmniTRAX took ownership of the Port in 1997, grain has represented $90 \%$ or more of the Port's export traffic and wheat has typically made up $90 \%$ of this grain volume (Meredith and Norquay, 2013). In recent years, grain has been shipped from the Port of Churchill to destinations in Central and South America, Europe, and Africa (J. McEachern, personal communication, November 18, 2014). In addition to exporting grain, the Port processes re-supply freight destined for the Kivalliq region of Nunavut; this freight includes essentially all items required by northern communities except for perishable goods, with cargo ranging from heavy machinery and vehicles to food items (F. Gaudreau, personal communication, March 20, 2015). The Port does not currently receive import vessels (J. McEachern, personal communication, November 18, 2014). 
Table 2.1: Key characteristics of the Port of Churchill's shipping operations (J. McEachern, personal communication, November 18th, 2014).

\begin{tabular}{|c|c|}
\hline Service & Description \\
\hline Shipping season & Roughly 11 weeks. Typically from early August to late October. \\
\hline $\begin{array}{l}\text { Average grain export } \\
1997-2014\end{array}$ & 500,000 metric tonnes per year, in non ice-strengthened bulk carriers \\
\hline Typical re-supply freight export & $7,500-10,000$ metric tonnes, in ice-strengthened vessels \\
\hline $\begin{array}{l}\text { Typical number of outgoing } \\
\text { trade vessels }\end{array}$ & $\begin{array}{l}\text { 19-20. An average of } 16 \text { grain vessels per year (1997-2014) and 3-4 re- } \\
\text { supply vessels carrying freight. }\end{array}$ \\
\hline
\end{tabular}

\section{The Port's grain exports, in context}

The volume of Arctic trade is very small relative to the trade moving through Canada's Atlantic, Asia-pacific, and central Ontario-Quebec regions. These three regions have been recognized as major trade and transportation gateways in a national policy framework by the Government of Canada; the Arctic region was not included in this framework (Meredith and Norquay, 2013). For comparison, the Port of Thunder Bay averaged a total tonnage of 7.9 million tonnes per year between 2012 and 2014, including an average export of 6.7 million tonnes of grain (Port of Thunder Bay, 2015). Over on the west coast, Port Metro Vancouver averaged a total tonnage of 132.8 million tonnes per year between 2012 and 2014 and an average export of 17.2 million tonnes of grain (Port Metro Vancouver, 2014).

It has been reported that with its current infrastructure and shipping season, the Port of Churchill can operate efficiently at 500,000 to 700,000 tonnes of grain per year. While there is a push from some of the Port's stakeholders to export 1 million tonnes per year, it has been suggested that this may require further infrastructure (J. McEachern, personal communication, February 18, 2014). At present, the focus for the Port is to ensure an annual export as close to 700,000 tonnes as possible in order to maximize profitability (J. McEachern, personal communication, February 18, 2014). To reach this target, the Port of Churchill must compete with the larger Canadian ports to attract grain shipments.

\section{Competing for grain shipments}

There are several marine operations-related disadvantages for the Port of Churchill in its competition for grain shipments. These competitive disadvantages have to do with the Port's relatively short shipping season, the Port's lack of third-party investment, and the added expense of Arctic shipping:

First, the Port of Churchill's shipping season does not overlap well with the timing of peak grain production in Canada. Constrained by sea ice and other logistical challenges, the Port typically only operates between July and October while peak time for grain shipping runs from September to December. Unless a grain company stores its late fall product until the following year they must look to other ports (E. Vido, personal communication, February 24, 2015). 
Second, it has been suggested that the relatively short shipping season makes grain companies less likely to invest in the Port of Churchill. Grain companies typically build their supply chains based on year-round demands and operations (E. Vido, personal communication, February 24, 2015). As a result, these companies do not make the Port of Churchill a central component of their supply chain. Grain companies own storage facilities at other Canadian grain ports but thus far there has been no such third party investment in the Port of Churchill. This may make shipping through Churchill less attractive, as grain companies can be influenced by the desire maximize use of their own assets when choosing a port (E. Vido, personal communication, February 24, 2015).

Third, marine insurance for Arctic waters is more expensive than for non-Arctic waters; this added cost raises the price of shipping through Churchill (E. Vido, personal communication, February 24, 2015).

The Port of Churchill also has several advantages when it comes to attracting grain shipments. For example:

Shipping through the Port of Churchill offers a cost advantage of $\$ 10$ to $\$ 25$ per tonne relative to competing ports on the St. Lawrence Seaway for grain producers in some areas of central Canada seeking to export grain to Atlantic destinations. This is due to the reduced transportation distances at each step between the grain field, the port, and various European destinations (Meredith and Norquay, 2013). The cost advantage helps the Port attract business.

The Port receives external assistance in attracting grain shipments. Between 1997 and 2012 the Canadian Wheat Board made a concerted effort to direct grain through the Port of Churchill. When the Government of Canada struck down the CWB's monopoly in 2012, it established a subsidy of roughly $\$ 9$ per tonne to promote continued shipping through the Port (Meredith and Norquay, 2013). This subsidy, called the Churchill Port Utilization Program, is scheduled to end in 2017 (Meredith and Norquay, 2013).

\section{Government support}

The Churchill Port Utilization Program is not the only government money that has been spent to support the Port of Churchill since its privatization. The Port is not currently considered to be a profitable enterprise and government support has been provided throughout the period of OmniTRAX's ownership in order to ensure continued operation and development (E. Vido, personal communication, February 24, 2015). The Hudson Bay Railway is reported to be a nearconstant source of costs. The Port itself has also required maintenance and upgrades in recent years (E. Vido, personal communication, February 24, 2015). All together, the governments of Canada and Manitoba have committed to a cumulative investment of $\$ 133$ million in direct support of the Port's operations between 1997 and 2017 (Meredith and Norquay, 2013). The federal and provincial government continue to direct money towards the Port because of the important role that the Port and the Hudson Bay Railway currently play in sustaining the town of Churchill and in connecting the northern communities of Manitoba and Kivalliq to the south (E. 
Vido, personal communication, February 24, 2015). Moreover, these governments are hopeful that the Port could grow into a profitable venture and a key link in the developing trade networks of the Arctic and central Canada (Meredith and Norquay, 2013).

\section{The Port's place in a changing Arctic}

These are dynamic times for the Port of Churchill and the Hudson Bay Complex, in both a natural and an economic context. Climate change is catalyzing significant and rapid changes in the Arctic environment: the temperatures of the ocean and the atmosphere are warming; sea ice regimes are shifting; the timing of the annual freeze and thaw cycle is changing, as are the movement patterns, location, volume, and thickness of the ice; new weather trends are emerging; and polar animals are changing their ecological cycles (Stewart and Lockhart, 2005). As these environmental changes are occurring, relatively intensive resource exploration and development is taking place throughout the Arctic. For example, 61 different mineral exploration projects are underway in the Kivalliq and Qikiqtaaluk regions of Nunavut (Meredith and Norquay, 2013). The Hudson Bay area is attracting investments in mineral exploration worth hundreds of millions of dollars. There is also potential for increased ecotourism and environmental research in the area (Meredith and Norquay, 2013).

The challenge for the Port of Churchill will be to capitalize on the Arctic opening that is underway while safely and sustainably navigating the many changes to the Arctic environment brought about by climate change and increasing development. In order to be successful in this venture the Port will likely need support from the scientific community. In this spirit, this project utilizes current scientific knowledge to analyze the climate-related vulnerabilities and opportunities for the Port of Churchill's marine operations from 2015 to 2050. Note: this project is focused exclusively on the Port's marine operations and will not directly address climaterelated issues relating to surface or air transportation to and from Churchill. 


\section{The Port of Churchill - Shipping Infrastructure and Operations}

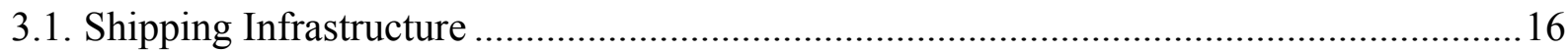

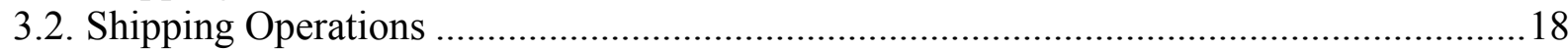

3.2.1. In Brief: Sea ice in the Hudson Bay Complex ……….......................................... 18

3.2.2. Shipping routes to the Port ................................................................................. 19

3.2.3. Navigation in the Hudson Bay Complex..................................................................20

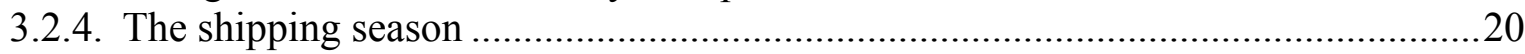

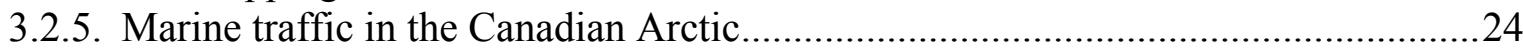

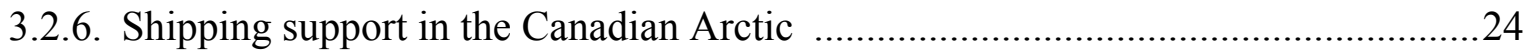

It is important to have a clear understanding of the Port's marine infrastructure and operations in order to understand and assess their climate-related vulnerabilities and opportunities.

\subsection{Shipping Infrastructure}

The Port's 4 berths, as numbered in Figure 3.1:

1. Berth 1: Tanker berth, $166 \mathrm{~m}$ long, $9.9 \mathrm{~m}$ draft

2. Berth 2: Grain berth, $232 \mathrm{~m}$ long, $11.5 \mathrm{~m}$ draft

3. Berth 3: Grain berth, $262 \mathrm{~m}$ long, $9.0 \mathrm{~m}$ draft

4. Berth 4: Lay-by berth, $255 \mathrm{~m}$ long, $10.0 \mathrm{~m}$ draft

The maximum draft given for each berth is for low tide (Port of Churchill, n.d.). The Port typically loads grain vessels one at a time, but is sometimes capable of loading two at once $(J$. Andersen, personal communication, March 13, 2015).

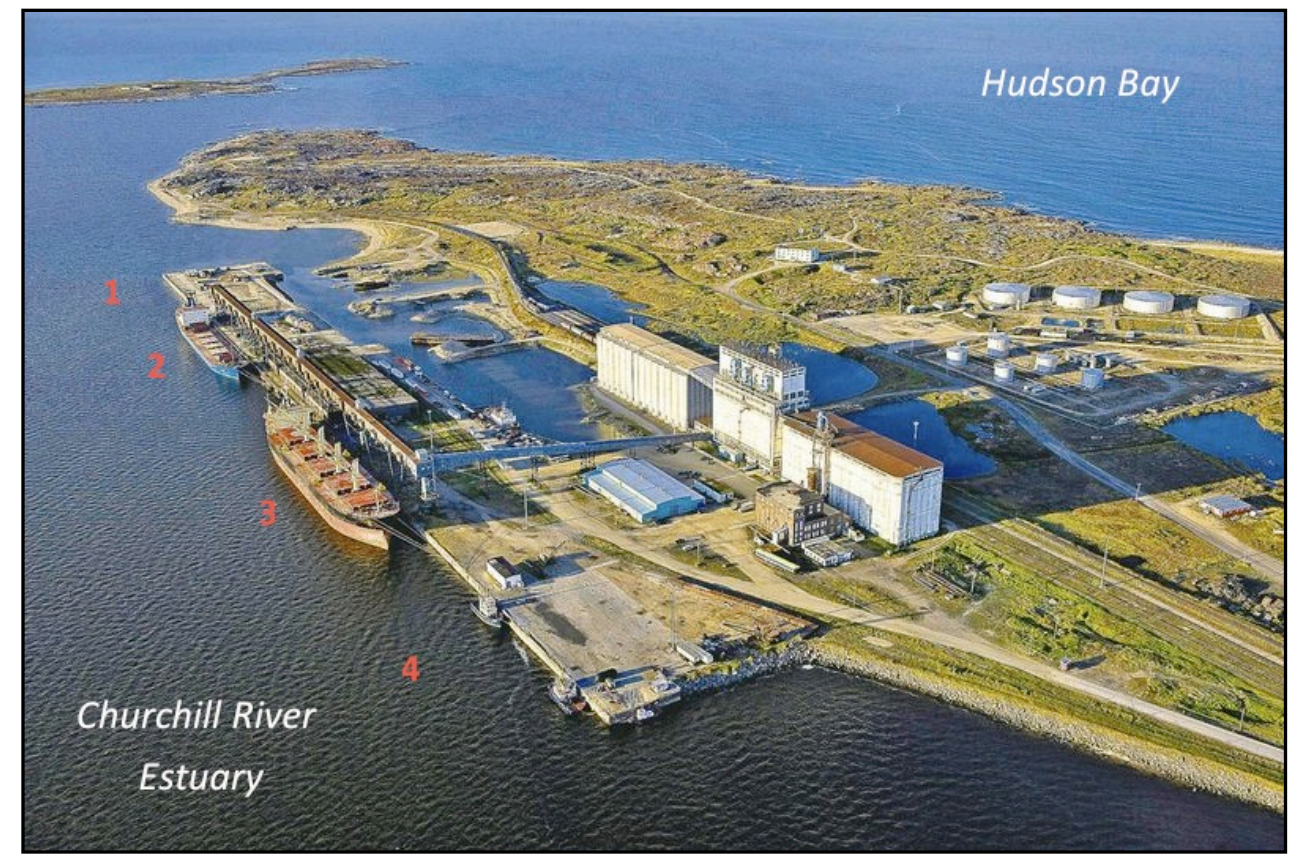

Figure 3.1: The Port of Churchill's wharf and shipping berths (Port of Churchill, n.d.). Photo modified from Winnipeg Free Press (2013). 
There are two tugboats that operate at the Port of Churchill and these boats play an integral role in the Port's operations (the tugs are visible in berth 4 of Figure 3.1). Tugs are responsible for turning grain ships around for docking and departing; they are also used to fight fires, deal with contaminant spills, and break any ice forming overnight in the port area during the fall, up to an ice thickness of roughly $20 \mathrm{~cm}$ ( $J$. Andersen, personal communication, March 13, 2015). Tugboats would also be used for any rescue operation near the port. It has been suggested that the two tugboats at the Port of Churchill are not sufficient for the Port's needs and that their shortcomings expose the Port to vulnerabilities and lost productivity ( $J$. Andersen, personal communication, March 13, 2015). It has also been suggested that adding a large and relatively modern tugboat to the fleet would largely address these issues ( $J$. Andersen, personal communication, March 13, 2015).

As mentioned in the introduction, the shipping vessels moving freight from the Port of Churchill are not owned by OmniTRAX, Inc., or any of its subsidiaries. The vessels used for carrying grain are owned by a variety of third parties and these vessels are typically not ice-strengthened ( $J$. McEachern, personal communication, February 18, 2014). Nunavut Sealink \& Supply Inc. (NSSI) uses a fleet of company owned, ice-strengthened vessels for its re-supply operations out of Churchill and throughout the Canadian Arctic ( F. Gaudreau, personal communication, March 20, 2015).

\section{Key point:}

Thus far, grain-shipping vessels carrying exports from the Port of Churchill have nearly all been non ice-strengthened bulk carriers. Ice-strengthened bulk carriers have been used only in very rare instances in the past to transport grain from the Port during November (J. McEachern, personal communication, February 18, 2015). Conversations with the Port's stakeholders indicate that there is little appetite amongst grain companies using the Port to hire icestrengthened vessels; stakeholders' suggestions of the likely deterrents for grain companies included the probability of added expenses, the thin profit margins of grain shipping, and the uncertainty of using unfamiliar shipping methods. 


\subsection{Shipping Operations}

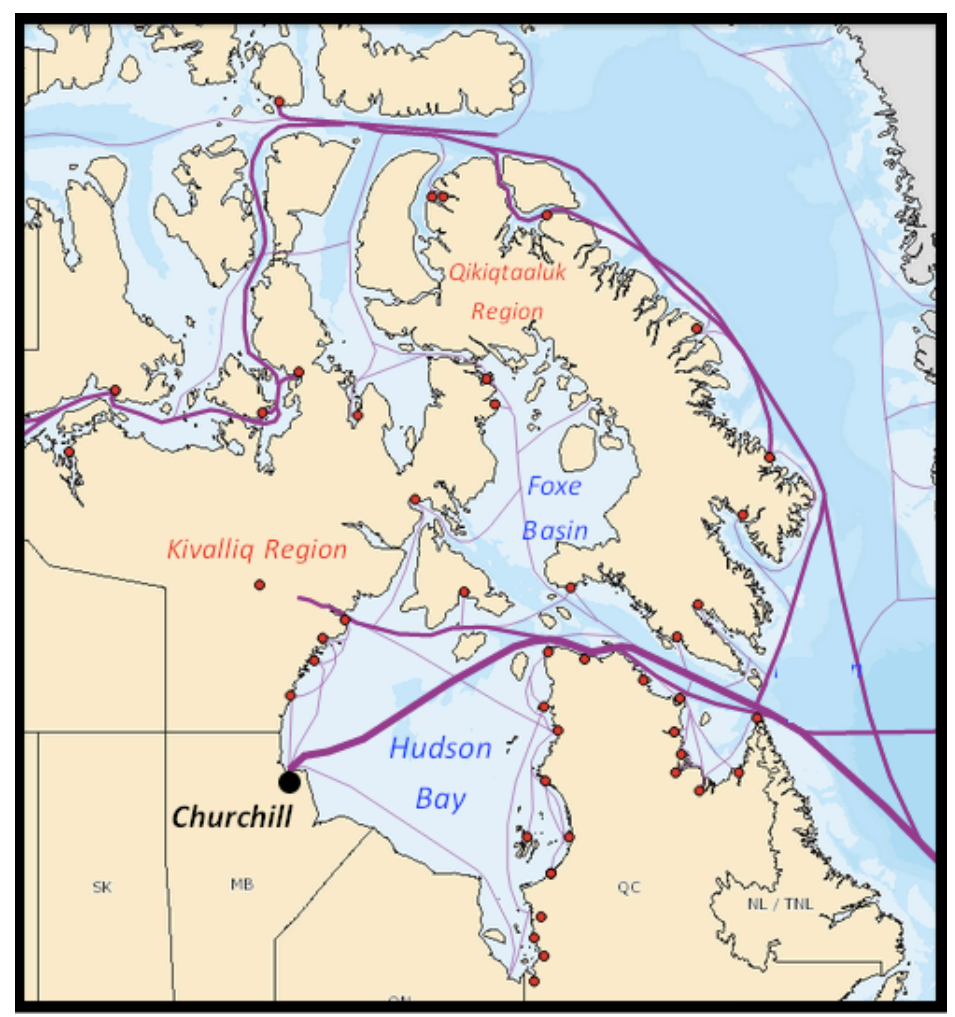

Figure 3.2: Shipping routes through the Hudson Bay Complex. Routes reflect 2010 vessel traffic, where the width of the lines on the map corresponds to the amount of vessel traffic, with thicker lines indicating more traffic (Modified from Arctic Voyage Planning Guide, 2013).

\subsubsection{In brief: Sea ice in the Hudson Bay Complex}

The timing and extent of sea ice in the Hudson Bay Complex is discussed at length in other sections of this document (e.g. pages 56 and 89). However, a brief outline of the historical timing of sea ice in the region has been included in this section to provide necessary context for this discussion of the Port's shipping operations.

Hudson Bay is typically ice free from late July or early August until early November. Hudson Strait is typically ice free from July to mid-November. Foxe Basin is typically ice free from midSeptember to mid-October (Hochheim and Barber, 2014).

Presenting the "typical" freeze-up and breakup times for sea ice in the Hudson Bay Complex is challenging and risks causing a misunderstanding. This is because freeze-up and breakup times are changing, both from year to year (termed inter-annual variability) and in long-term trends. Therefore it is important to remember that the "typical" timing of sea ice in the Hudson Bay Complex in reality reflects only a snapshot of what was normal in recent history. 


\subsubsection{Shipping routes to the Port}

\section{Grain Vessels}

Vessels traveling directly to the Port of Churchill (e.g. grain vessels) enter the Hudson Bay Complex via Hudson Strait. After travelling through the Strait and beyond Mansel Island, which lies just west of the north-western corner of mainland Quebec, the vessels travel a direct route across Hudson Bay to Churchill (Figure 3.2). Loaded vessels follow the same route after departing the Port (J. Andersen, personal communication, March 13, 2015). Grain vessels take roughly two and a half days to travel from the Port to the mouth of Hudson Strait $(J$. Andersen, personal communication, March 13, 2015).

Before a shipping vessel can enter or depart the port, permission must be granted by the Port Warden (J. Andersen, personal communication, March 13, 2015). While inside the Port of Churchill harbour, all vessels must be guided by a port pilot. The harbour boundary is defined by a buoy which lies roughly $5 \mathrm{~km}$ out from the mouth of the Churchill estuary (Port of Churchill, n.d). One of the Port's two tugboats is used to move pilots between the port and incoming or outgoing vessels that have reached the edge of the harbour ( $J$. Andersen, personal communication, March 13, 2015). A tugboat is also used to turn grain vessels before or after unloading and to assist with docking and departing. These tugboat operations can be very challenging in heavy weather and at times operations must be put on hold to wait for calmer conditions (J. Andersen, personal communication, March 13, 2015).

\section{Marine re-supply}

The re-supply vessels that use the Port of Churchill are operated by the Montreal based Nunavut Sealink \& Supply Inc. (NSSI). NSSI provides marine re-supply for communities and private industry projects throughout Northern Quebec (Nunavik), Kivalliq, Kitikmeot, and Qikiqtaaluk; however, all re-supply freight exported from the Port of Churchill is currently destined exclusively for Kivalliq (F. Gaudreau, personal communication, March 20, 2015). In 2014, NSSI conducted 19 re-supply voyages into the eastern Canadian Arctic, 4 of which travelled to the Port of Churchill (Nunavut Sealink \& Supply Inc., 2014).

At present, all NSSI re-supply voyages begin in southern Quebec and access the Hudson Bay Complex from the eastern end of Hudson Strait. Re-supply vessels on voyages that include the Port of Churchill travel variable routes through the Complex. The vessels typically make several stops in Hudson Strait before either heading north into Foxe Basin or south along the eastern coast of Hudson Bay (Nunavut Sealink \& Supply Inc., 2014). The vessels then head to the Port of Churchill where they reload with re-supply freight that is destined for the Kivalliq region $(F$. Gaudreau, personal communication, March 20, 2015). Finally, after stopping in Kivalliq the vessels travel home to Montreal, with a few stops along the way in Qikiqtaaluk and northern Quebec (Nunavut Sealink \& Supply Inc., 2014).

Very few of the towns visited by NSSI vessels for re-supply are equipped with any port infrastructure. As a result, freight must be placed on barges and unloaded on the beach at nearly 
every destination. This adds significant logistical challenges and risk to the re-supply operations (F. Gaudreau, personal communication, March 20, 2015).

\subsubsection{Navigation in the Hudson Bay Complex}

A 2014 audit of marine navigation in the Canadian Arctic completed by the Office of the Auditor General of Canada found that there are inadequate hydrographic data for nearly all of the Hudson Bay Complex, including many of the areas used by vessels traveling to and from the Port of Churchill (Office of the Auditor General of Canada, 2014). The audit concluded that many of the charts available to mariners for the Canadian Arctic may not be current or reliable (Office of the Auditor General of Canada, 2014). However, it has been reported that the shipping route used by vessels travelling directly to and from the Port is quite well established and that although the surveys can be old and imprecise, there is sufficient open water for relatively safe travel when weather and ice conditions are appropriate for shipping (J. Andersen, personal communication, March 13, 2015). With regards to re-supply operations, François Gaudreau of NSSI did not mention a lack of hydrographic data as a major concern during a conversation about the challenges for NSSI's operations in the Hudson Bay Complex (F. Gaudreau, personal communication, March 20, 2015).

\subsubsection{The shipping season}

\section{Shipping dates in recent years}

The Port of Churchill's website advertises a shipping season of 14 weeks, from July $15^{\text {th }}$ to October $31^{\text {st }}$ (Port of Churchill, n.d.). In fact, between 2009 and 2014 the grain-shipping season typically ran from early August to late October and averaged 11.2 weeks in length. The earliest grain shipment during this time departed the Port of Churchill on July $28^{\text {th }}, 2010$, while the latest grain shipment left the Port of Churchill on November $2^{\text {nd }}, 2014$ (Table 3.1). Re-supply shipments occur during the same time period, though NSSI's re-supply vessels sometimes reach the Port one or two weeks before the grain vessels first arrive (J. McEachern, personal communication, November 18, 2014). In 2014, four Sealink re-supply vessels reached Churchill, with the first arriving on July $18^{\text {th }}$ and the last departing on October $19^{\text {th }}$ (Nunavut Sealink \& Supply Inc., 2014).

Table 3.1: Grain vessel sailings and the length of the grain-shipping season for the Port of Churchill between 2009 and 2014 (J. McEachern, personal communication, November 18, 2014).

\begin{tabular}{|c|c|c|c|c|}
\hline Year & $\begin{array}{c}\text { Number of } \\
\text { Grain Sailings }\end{array}$ & Start Date & End Date & $\begin{array}{c}\text { Season Length } \\
\text { (Weeks) }\end{array}$ \\
\hline $\mathbf{2 0 1 4}$ & 16 & 08-Aug & 02-Nov & 12.3 \\
\hline $\mathbf{2 0 1 3}$ & 17 & 12-Aug & 31-Oct & 11.4 \\
\hline $\mathbf{2 0 1 2}$ & 15 & 10-Aug & 30-Oct & 11.6 \\
\hline $\mathbf{2 0 1 1}$ & 17 & 03-Aug & 17-Oct & 10.7 \\
\hline $\mathbf{2 0 1 0}$ & 22 & 28-Jul & 18-Oct & 11.7 \\
\hline $\mathbf{2 0 0 9}$ & 18 & 12-Aug & 17-Oct & 9.4 \\
\hline Average & 17.5 & 07-Aug & 24-Oct & 11.2 \\
\hline
\end{tabular}




\section{Regulations}

The shipping season in the Hudson Bay Complex is regulated by Transport Canada. Regulations vary between the northern (north of $60^{\circ} \mathrm{N}$ ) and southern (south of $60^{\circ} \mathrm{N}$ ) regions of the Complex. Shipping in the northern region of the Hudson Bay Complex is regulated under the Arctic Waters Pollution Prevention (AWPP) Act. Shipping vessels travelling to and from the Port of Churchill must ship under the AWPP Act's "Zone/Date System" or the Arctic Ice Regime Shipping System (AIRSS):

The Zone/Date System regulates the dates during which shipping vessels may enter any one of 16 "Shipping Control Zones" in the Canadian Arctic (Figure 3.3, below). The Zone/Date System was developed around the seasonality of sea ice in each zone and varies according to the size and type of vessel (Transport Canada, 2010a). As described in section 3.1, the re-supply vessels used by NSSI are ice-strengthened while the grain-carrying vessels leaving the Port of Churchill typically are not (J. Andersen, personal communication, March 13, 2015). Under the Zone/Date System, non ice-strengthened ships may enter northern Hudson Bay on July $20^{\text {th }}$ and must depart by October $31^{\text {st }}$ (Figure 3.3) (Minister of Justice, 1985). The Zone/Date System is fixed and is inflexible to long term trends or inter-annual variability in sea ice conditions (Transport Canada, 2010a).

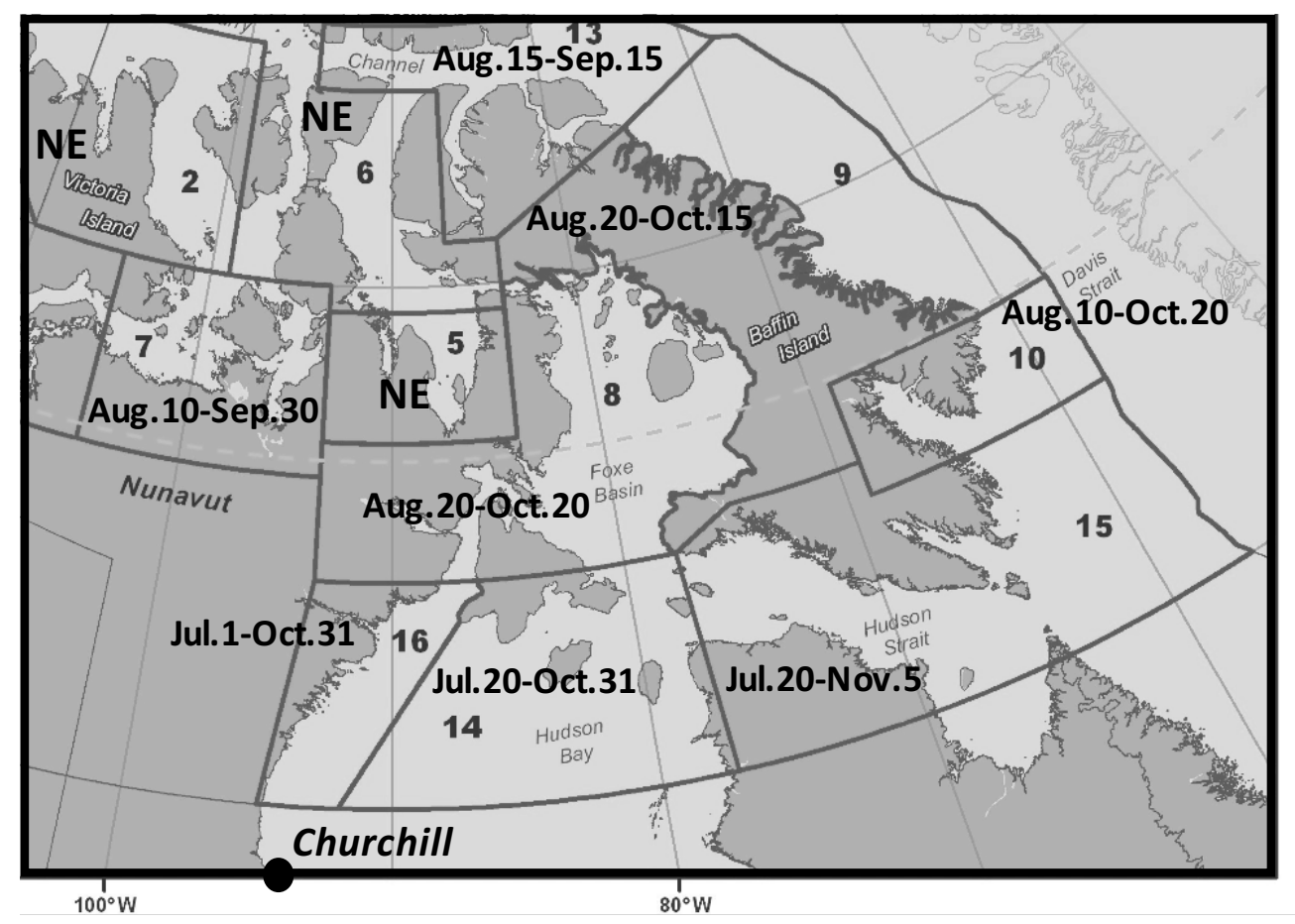

Figure 3.3: The Shipping Control Zones of the eastern Canadian Arctic, and the access dates for non icestrengthened ships set down in the Zone/Date System (NE signifies No Entry). Modified from Minister of Justice, 1985.

The Arctic Ice Regime Shipping System (AIRSS) was created as a response to the inflexibility of the Zone/Date System. The AIRSS permits and regulates the operation of shipping vessels in the 
Canadian Arctic outside of the dates established in the Zone/Date System (Transport Canada, 2010a). Instead of applying rigid dates, the AIRSS determines whether a given vessel may enter an Arctic area using a calculation that considers the present ice-regime of the area and the icecapacity of the vessel (Transport Canada, 2010a). Under the AIRSS, it is possible for non icestrengthened vessels to travel to the Port of Churchill before July $20^{\text {th }}$ or after October $31^{\text {st }}$, so long as ice-conditions are appropriate (Transport Canada, 2010a; J Andersen, personal communication, March 13, 2015).

Nearly all grain shipping to and from the Port of Churchill has been conducted within the dates of the Zone/Date System and the AIRSS has very rarely been used (J. McEachern, personal communication, November 18, 2014; E. Vido, personal communication, February 24, 2015; J Andersen, personal communication, March 13, 2015). It is not entirely clear why this is. A number of possible explanations arose during conversations with Port stakeholders. For example, it could be that ice conditions are typically too severe for non ice-strengthened vessels outside of the July $20^{\text {th }}$ to October $31^{\text {st }}$ window of the Zone/Date System, and thus the vessels typically used for grain shipping are unable to access the Port. It is also possible that the cost of marine insurance for sailing outside of the dates of the Zone/Date System are prohibitive, or that insurance is not available during those dates (more information on marine insurance is provided below). Finally, it is possible that the AIRSS is not well understood by shippers.

Shipping in the southern region (south of $60^{\circ} \mathrm{N}$ ) of the Hudson Bay Complex is not covered by the AWPP Act but does fall within the Northern Canada Vessel Traffic Services Zone (NORDREG). The NORDREG jurisdiction spans Canada's northern waterways and the regulations require that shipping vessels report plans to the Canadian Coast Guard prior to entering an area, position reports while in the area, and a final report after exiting Canada's northern waters (Canadian Coast Guard, 2013).

\section{Marine insurance}

In addition to the limitations and requirements established by the Canadian shipping regulations, vessels using the Port of Churchill are also influenced by the requirements of marine insurance. Ship owners are responsible for purchasing insurance for their vessel. When traveling along traditional (non-Arctic) trade routes, vessels pay insurance premiums based on their assignation in a complex classification system, which is based on the vessels engineering attributes $(J$ Andersen, personal communication, March 13, 2015). Marine insurers often add a surcharge of roughly $15 \%$ for travel along the route to Churchill through the Hudson Bay Complex between August $15^{\text {th }}$ and October $15^{\text {th }}$. Outside of these dates, surcharges typically rise to $25 \%$ (E. Vido, personal communication, March 12, 2015). The parameters of marine insurance can have a strong influence on Arctic shipping. For example, some insurers will not allow non icestrengthened vessels to remain in the Hudson Bay Complex as October $31^{\text {st }}$ approaches $(J$. Andersen, personal communication, March 13, 2015). When this happens, the result could be an effective shortening of the shipping season created by the legal regulations. 


\section{Looking ahead}

Shipping through the Port of Churchill is the net result of a complex mixture of supply and demand, marine regulations, insurance requirements, and environmental factors. At present, the grain-shipping season begins in late July or early August and is typically over by late October, which is within the confines of the Zone/Date system (J. McEachern, personal communication, November 18, 2015).

Sea ice conditions in the Hudson Bay Complex sometimes remain favourable for shipping after October $31^{\text {st }}$ (J. McEachern, personal communication, February 18, 2015) and current scientific research indicates a trend towards later freeze-up in the Hudson Bay Complex (Hocheim and Barber, 2014). While the changing ice conditions may extend the open water season in the Complex and there is interest amongst the Port of Churchill's stakeholders in an extension of the shipping season, further evidence and discussion will likely be required to convince grain companies, shippers, insurers and regulators that the shipping season can safely be extended into November. It should be mentioned that discussions of a season extension are focussed on shipping later into the fall and not earlier in summer ( $S$. Harrison, personal communication, March 12, 2015). The potential for an extension of the Port of Churchill's shipping season is further discussed in sections 4.3 and 7.3.

The re-supply vessels run by Nunavut Sealink \& Supply Inc. enter the Hudson Bay Complex as soon as the sea ice will permit and attempt to fit as much shipping as possible into the open water season (F. Gaudreau, personal communication, March 20, 2015). In 2014, NSSI vessels entered the Hudson Bay Complex and reached the east coast of Quebec in early July. Their first arrival in the area of Churchill and Kivalliq was in mid-July and their latest departure from the area was in late-October (Nunavut Sealink \& Supply Inc., 2014).

NSSI now typically loads vessels in southern Quebec two weeks earlier than it did 15 years ago, although this change is a product of both newer and more capable vessels and changes in icebreakup dates within the Hudson Bay Complex ( $F$. Gaudreau, personal communication, March 20, 2015). There has not been a similar extension into the fall during this same time frame. Interestingly, the end of the shipping season is not only driven by sea ice formation, but may also be caused by strong winds that make operations impossible (F. Gaudreau, personal communication, March 20, 2015). Recall that NSSI operators must contend with the challenges of unloading freight onto beaches in most re-supply destinations, as very few towns in the Complex have any marine infrastructure to speak of ( $F$. Gaudreau, personal communication, March 20, 2015). 


\subsubsection{Marine traffic in the Canadian Arctic}

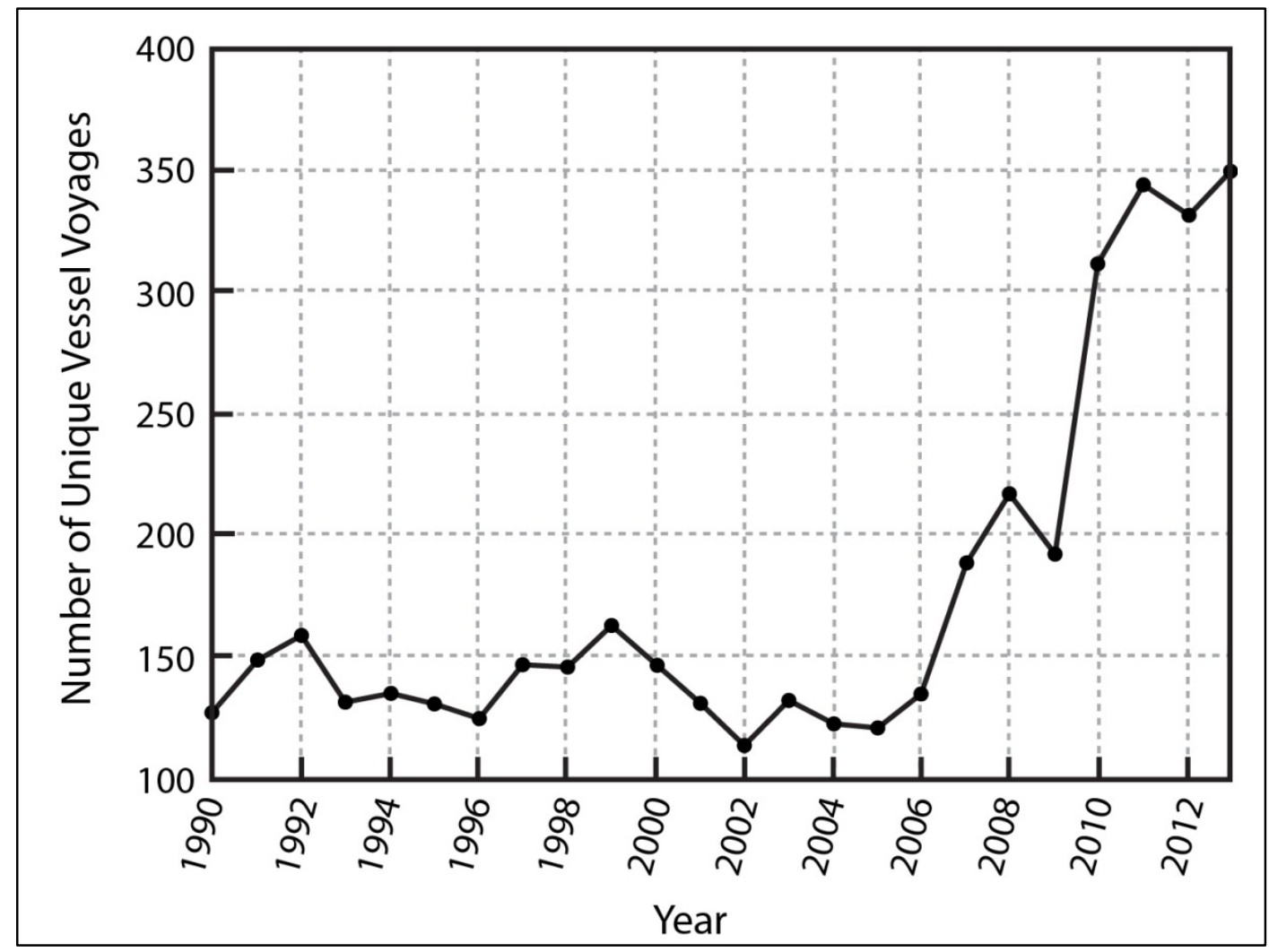

Figure 3.4: Number of unique vessel voyages within the Canadian Arctic each year. "Unique" signifies that vessels were counted only once for each trip into the Arctic. Adapted from J. Dawson, University of Ottawa. Compiled from Canadian Coast Guard datasets.

The number of vessels within the Canadian Arctic has increased during recent years (Figure 3.4). This increase has been enabled in part by reductions in Arctic ice cover, and reflects trends in cruise ships, resource-exploration vessels, and grain vessels. Shipping traffic in Hudson Strait more than doubled between 1990 and 2008 and the area now has nearly double the traffic of any other zone in the Canadian Arctic (Judson, 2010).

Despite the increase in Arctic traffic in recent decades, both the rate of shipping accidents per voyage and the number of accidents per year have trended downwards. However, Hudson Strait is one of the three areas where traffic accidents tend to be concentrated and the Strait has been labelled a relatively "high-casualty" area (Judson, 2010).

\subsubsection{Shipping support in the Canadian Arctic}

There is some concern that Canada is not equipped to handle the increased traffic volume in Arctic waters. Specific attention has been focused on the Canadian Coast Guard's fleet of icebreakers and whether they are capable of meeting current and future user needs in the Arctic (Office of the Auditor General of Canada, 2014). Icebreakers play a variety of roles in the Canadian Arctic, ranging from route assistance and harbour breakouts to simply ensuring a 
Canadian presence for the sake of affirming sovereignty (Canadian Coast Guard, 2009). The Canadian Coast Guard currently operates six icebreakers in the Arctic during the summer and early fall (Canadian Coast Guard, 2014). Icebreakers are typically present in Hudson Bay and Hudson Strait between July $3^{\text {rd }}$ and October $24^{\text {th }}$, and in Foxe Basin between August $20^{\text {th }}$ and September $15^{\text {th }}$ (Canadian Coast Guard, 2009). During the winter months, the nearest icebreaker to the Hudson Bay Complex is positioned off the coast of Newfoundland (Canadian Coast Guard, 2009).

A 2014 audit of marine navigation in the Canadian Arctic found that Environment Canada's marine weather and ice-information services were improving but face new challenges and require further work (Office of the Auditor General of Canada, 2014). The audit also found that Transport Canada's system for supporting the enforcement of marine safety and pollution laws could use further development in some aspects of surveillance and monitoring (Office of the Auditor General of Canada, 2014). The audit concluded, at the time of its completion in the fall of 2014, that "there is no long-term national vision or coordinated departmental strategies to support safe marine transportation in the Arctic" (Office of the Auditor General of Canada, 2014). The audit did not examine Arctic maritime search and rescue operations, a service provided by the Canadian Coast Guard. However, research out of the University of Ottawa in 2014 found that Canada's search and rescue system is increasingly challenged to provide adequate service for the Arctic region and will be incapable of meeting the growing demands of the Arctic without making significant adjustments (Goegebeur, 2014).

\section{The Port of Churchill - Future Prospects (2030-2050)}

4.1. Freight movement through the Port of Churchill: cargo and volume .............................26

4.2. The Port of Churchill's freight supply chains .........................................................28

4.3. The Port of Churchill's shipping operations: potential changes ..................................28

4.4. The Port of Churchill's infrastructure: planned climate change adaptation .....................29

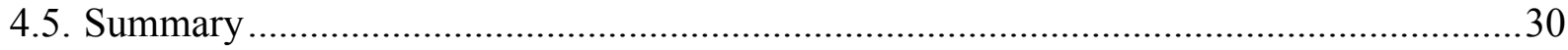

This project assesses the climate-related vulnerabilities and opportunities for the Port of Churchill's marine operations, extending to 2030 and 2050. The Port's current marine infrastructure and operations have been detailed in the sections above. The following section presents some information on how the infrastructure and operations may change and develop in the future. This information is the product of interviews with several of the Port of Churchill's central stakeholders. A federal-provincial taskforce on the future of Churchill also provided valuable insight (see Meredith and Norquay, 2013).

As detailed in previous sections, the Port of Churchill currently deals primarily in grain; exporting roughly 500,000 tonnes per year in 16-17 bulk-carrier shipments over the course of a season that typically runs from early August to late October (see Table 3.1). The Port also handles a wide variety of re-supply freight, averaging 7,500-10,000 tonnes per year carried in 3 
or 4 shipments with ice-strengthened vessels. The potential changes in the Port of Churchill's marine infrastructure and operations are outlined below. The organization of information is derived from a format used by $\mathrm{Ng}$ et al. (2013) in an examination of Australian ports in a climate-change context.

\subsection{Freight movement through the Port of Churchill: cargo and volume}

\section{Grain:}

The highest priority at OmniTRAX for the Port of Churchill is achieving a grain export of 700,000 tonnes each year within the currently available shipping season. A target of 1 million tonnes is the long-term objective for the Port (J. McEachern, personal communication, February 18, 2015).

The Port's grain exports depend on grain prices, and these are difficult to predict. The fluctuation in grain prices over the years will affect the profit margin for shipping through Churchill and therefore will influence the quantity of grain leaving the Port (J. McEachern, personal communication, February 18, 2015). Moreover, the subsidy provided by the Churchill Port Utilization Program is scheduled to end in 2017; however, it is possible that this subsidy will be extended (E. Vido, personal communication, February 24, 2015).

There are several infrastructural and operational changes that could be made at the Port of Churchill in the near future that have the potential to increase grain exports. First, early season efficiency could be improved by filling the Port's storage in the fall and using this grain to load the first shipments of the season in July (J. McEachern, personal communication, February 18, 2015). Second, the Port owners could invest in infrastructure that enables the handling of a wider variety of grain (Meredith and Norquay, 2013). Third, the Port could improve on a number of operational inefficiencies which cause lost time and productivity during the shipping season $(J$. Andersen, personal communication, March 13, 2015).

Two long-term developments that could influence the Port's grain exports involve the shipping season and the Hudson Bay Railway:

First, there is a distinct possibility of an extension to the shipping season by 2030 or 2050 . This could extend the Port's operation window into Canada's peak grain-shipping months (November and December) and could result in a major increase in grain exports (E. Vido, personal communication, February 24, 2015). The many dimensions of a season extension are further discussed in the Vulnerabilities and Opportunities Section (page 102).

Second, the Hudson Bay Railway may be sufficiently improved to allow for more dependable, more expedient, and larger deliveries of grain to the Port (E. Vido, personal communication, February 24, 2015). The railway is currently a link in the supply chain that significantly hinders grain exports (J. Andersen, personal communication, March 13 2015). 


\section{Re-supply freight}

There is growth in the population and industry of the Kivalliq region of Nunavut. The Port provides re-supply freight to this region and the quantity of freight will likely grow, especially in the areas of housing supplies and municipal and industrial infrastructure (E. Vido, personal communication, February 24, 2015; J. McEachern, personal communication, February 18, 2015). Mining companies in Nunavut typically link their operations with services operating out of southern Quebec. However, the Port of Churchill could be called upon to support some companies with re-supply during the exploratory phases of mining projects, before companies establish their own supply-chain systems (J. McEachern, personal communication, February 18, 2015).

Nunavut re-supply is one focus of the Winnipeg-based CentrePort Canada, a growing transportation hub for national and international trade (E. Vido, personal communication, February 24, 2015). The Nunavut re-supply industry could grow and change significantly by 2030 or 2050. Currently most re-supply from Manitoba is completed over land and air, and these operations will grow as new roads begin to extend farther north. Nevertheless, it is likely that shipping re-supply through the Port of Churchill will also grow beyond the current level of 3 to 4 shipments per year (E. Vido, personal communication, February 24, 2015). Note that most communities in the Hudson Bay Complex must rely on airplane-carried freight for all re-supply not brought in by ship, a significantly more expensive alternative ( $A$. Ng, personal communication, February 13, 2015).

\section{Potash}

It has been reported that potash is most likely the next commodity to begin moving through the Port of Churchill and that this is likely to happen before 2030 or 2050 (J. McEachern, personal communication, February 18, 2015). Several new potash companies are developing within the catchment areas of the Port of Churchill and the Port's stakeholders are hopeful that these companies will use the Port to reach their customers in the Atlantic basin (J. McEachern, personal communication, February 18,2015$)$. Potash is a more valuable commodity than grain, with a higher profit margin; it is possible that this increased margin could motivate more shipping in November, despite the increased expense of shipping in that month (J. McEachern, personal communication, February 18, 2015).

\section{Oil}

The movement of oil through the Port of Churchill is a somewhat contentious issue in Manitoba. In August of 2014 OmniTRAX Canada announced the suspension of its plan to ship crude oil through the Port in the face of opposition from environmental groups, aboriginal groups, and some members of the Manitoba Government. Merv Tweed, CEO of OmniTRAX Canada, cited strong grain and re-supply exports as the reasoning for the 2014 decision not to ship oil and did not rule out the possibility of shipping oil in the future (McNeill, 2014).

According to Jeff McEachern, vice president of operations at the Hudson Bay Port Company, the business case for shipping oil through the Port has been proven but at present this plan has 
been put on hold due to a lack of political support. Nonetheless, Mr. McEachern believes that the shipment of oil from the Port of Churchill may take place at some point in the future $(J$. McEachern, personal communication, February 18, 2015).

\section{Other cargo types}

Briefly, it is possible that coal and wood pellets will be moved through the Port of Churchill before 2050 (J. McEachern, personal communication, February 18, 2015). The FederalProvincial Taskforce on the Future of Churchill also listed the shipment of Liquefied Natural Gas (LNG) to northern communities and mining projects as an opportunity for the Port of Churchill within the next 10 to 15 years (Meredith and Norquay, 2013).

\subsection{The Port of Churchill's freight supply chains}

The governments of Manitoba and Canada spent roughly $\$ 48$ million on rail-line rehabilitation and port upgrades for the Hudson Bay Railway and Port of Churchill between 2007 and 2013 (Meredith and Norquay, 2013). Nevertheless, the rail line is still a cause of significant delays and inefficiencies and will require further work (E. Vido, personal communication, February 24, 2015). Depending on financial investment and different environmental factors the rail line will certainly change between the present, 2030, and 2050, but it is not entirely clear what this change will look like.

The government of Manitoba has supported the idea of building an all-weather road to Churchill and Rankin Inlet. This road will quite likely be built by 2050 and will be preceded by a winter road. With respect to the Port of Churchill, a year-round road could stabilize the supply chain to the Port and in turn increase the volume of re-supply freight leaving the Port (E. Vido, personal communication, February 24, 2015).

\subsection{The Port of Churchill's Shipping Operations: Potential Changes}

\section{Alternate shipping routes}

Large bulk carriers travelling between the Port of Churchill and the Atlantic Ocean are not likely to deviate from their current route (A. Ng, personal communication, February 13, 2015). Resupply vessels will also continue to travel current routes to and from Churchill. There are two possibilities for change in re-supply shipping: a back-and-forth service between Churchill and Kivalliq during the open water season could begin, or the Port could begin to service areas beyond Kivalliq. However, it has been reported that there is presently not enough economic motivation to bring these changes about and it is not clear whether or not there will be in the near future (F. Gaudreau, personal communication, March 20, 2015).

Two further shipping routes are sometimes discussed in connection with the Port of Churchill: the Northwest Passage and the "Arctic Bridge".

With regards to the Northwest Passage, Adolf Ng, Associate Professor of Maritime Transport and Logistics Management at the University of Manitoba, is of the opinion that there is little economic sense or motivation behind shipping through this route (A. $\mathrm{Ng}$, personal 
communication, February 13, 2015). The Port's central stakeholders appear to agree, as the Churchill Gateway Development Corporation was not conducting any investigation into the possibilities of shipping through the Northwest Passage prior to the CGDC's closure in March 2015 (J. McEachern, personal communication, February 18, 2015).

The "Arctic Bridge" is a proposed route between the Port of Churchill and the Russian Arctic port of Murmansk. This route follows the traditional shipping course through Hudson Strait into the Labrador Sea before changing course for Murmansk in Northern Russia (CentrePort Canada, 2012). The Port of Churchill has exported grain to Russia in the past and the Premier of Manitoba signed a letter of intent to further develop the Arctic Bridge in 2002 (Manitoba Government, 2002). Since then, the Churchill-Murmansk connection has only been completed 3 times, and it has not been used since 2008 (Hudson Bay Route Association, n.d.).

\section{Two-way shipping}

Stakeholders in the Port of Churchill are hopeful that the Port will be engaged in two-way shipping by 2030 or 2050 (J. McEachern, personal communication, February 18, 2015). This two-way shipping is most likely to be realized through a future potash export supply chain and would likely involve the import of nitrogen or urea for fertilizer (J. McEachern, personal communication, February 18, 2015). The Port will require increased infrastructure to handle imports, and the imports may only arrive at occasional intervals, relying on short-term contracts and opportunism (J. McEachern, personal communication, February 18, 2015).

\section{Season extension}

There is a desire for an extension of the Port of Churchill's shipping season amongst all of the Port's central stakeholders. Shipping later into the fall is most frequently discussed, but earlier shipping in the spring could be of interest as well if conditions become more favourable earlier in the year. The Port of Churchill's current shipping season length is a product of a complex mix of factors, including environmental conditions, the market demand for the Port's export products, marine insurance requirements, and arctic shipping regulations. The argument for an extension to the shipping season is thoroughly discussed in the Vulnerabilities and Opportunities section (page 102).

\subsection{The Port of Churchill's infrastructure: planned climate change adaptations}

There are currently no adaptations planned for the Port of Churchill's marine infrastructure in response to climate change. The Port's wharf receives regular maintenance to keep up with ice damage caused by the motion of ice and the strong tides within the Churchill estuary, but this maintenance is not a response to new or abnormal behavior of the climate or environment $(J$. McEachern, personal communication, February 18, 2015). 


\subsection{Summary}

The following is a rough outline of the anticipated changes in the Port of Churchill's marine operations extending to 2030 and 2050; the outline is based on interviews with representatives of several of the Port of Churchill's central stakeholders (e.g. The Churchill Gateway Development Corporation, Manitoba Infrastructure and Transportation, Nunavut Sealink \& Supply, The Hudson Bay Route Association, etc...).

- Grain shipment volumes are difficult to predict but it appears likely that grain shipping may become more common in the later part of the shipping season.

- Re-supply shipping will likely increase somewhat.

- The Port may diversify commodities. Potash is the most likely cargo to be added but oil and other fuel products are also possible.

- Imports may begin to arrive at the Port on an occasional basis.

- There may be a strong push amongst stakeholders for a slackening of the constraints against shipping farther into the fall. Shipping outside of the dates prescribed in the Zone/Date System will likely become more common. 


\section{References}

Arctic Voyage Planning Guide [Map]. (2013). Retrieved from Fisheries and Oceans Canada website: http://geoportal.gc.ca/eng/Gallery/MapProfile/5

Canadian Coast Guard. (2014, December). Icebreaking Program [website]. Retrieved from http://www.ccg-gcc.gc.ca/eng/CCG/Ice_Who_We_Are

Canadian Coast Guard. (2013, June 24). Vessel Traffic Reporting Arctic Canada Traffic Zone (NORDREG) [website]. Retrieved from http://www.ccggcc.gc.ca/eng/MCTS/Vtr_Arctic_Canada

Canadian Coast Guard. (2009, December). Icebreaking Operations Directive 1: Provision of Icebreaking Services. Retrieved from Government of Canada, Canadian Coast Guard website: http://www.ccg-gcc.gc.ca/eng/CCG/Ice_Home/Ice_Publications/Directive1Icebreaking-Services

Cash, M. (2015, January 31). Axworthy quits in frustration. Winnipeg Free Press. Retrieved from http://www.winnipegfreepress.com/local/axworthy-quits-in-frustration290414151.html

CentrePort Canada. (2012). CentrePort Canada- Gateways [website]. Retrieved from http://www.centreportcanada.ca/gateways

Goegebeur, B. (2014, November). Canadian Arctic Search and Rescue: An Assessment. University of Ottawa: Research papers from the Faculty of Social Sciences. Retrieved from: https://www.ruor.uottawa.ca/handle/10393/31976

Hochheim, K. P., \& Barber, D. G. (2014). An update on the ice climatology of the hudson Bay system. Arctic, Antarctic, and Alpine Research, 46(1), 66-83. doi:10.1657/1938-424646.1.66

Hudson Bay Route Association. (n.d.). Churchill Facts [webpage]. Retrieved from http://www.hbra.ca/CHfacts.php

Judson, B. (2010, January). Trends in Canadian Arctic Shipping Traffic-Myths and Rumours. In The Twentieth International Offshore and Polar Engineering Conference. International Society of Offshore and Polar Engineers.

Meredith, D., \& Norquay, D. (2013, January). Federal-Provincial Task Force on the Future of Churchill, Retrieved from the Government of Manitoba, Manitoba Infrastructure and Transportation website: https://www.gov.mb.ca/mit/pdf/churchill.pdf

McNeill, M. (2014, August 14). OmniTrax suspends plan to ship crude oil through Port of Churchill. Winnipeg Free Press. Retrieved from http://www.winnipegfreepress.com/business/OmniTrax-suspends-plan-to-ship-crude-oilthrough-Port-of-Churchill--271319961.html

Manitoba Government. (2002, February 12). News Release-Premier Signs Letter of Intent to Further Develop Arctic Bridge [online]. Retrieved from http://www.gov.mb.ca/chc/press/top/2002/02/2002-02-15-05.html

Minister of Justice. (1985). Arctic Waters Pollution Prevention Act-Shipping Safety Control Zones Order. Retrieved from Department of Justice, Justice Laws website: http://lawslois.justice.gc.ca/eng/acts/A-12/ 
Ng, A. K., Chen, S. L., Cahoon, S., Brooks, B., \& Yang, Z. (2013). Climate change and the adaptation strategies of ports: The Australian experiences. Research in Transportation Business \& Management, 8, 186-194.

Nunavut Sealink \& Supply Inc. (2014). Arctic Re-supply Service Schedule. Retrieved from http://www.arcticsealift.com/en/medias/2015_CALENDAR_list_of_municipalities.pdf

Office of the Auditor General of Canada. (2014, Fall). Report of the Commissioner of the Environment and Sustainable Development - Chapter 3: Marine Navigation in the Canadian Arctic. Retrieved from http://www.oagbvg.gc.ca/internet/English/parl_cesd_201410_03_e_39850.html

Port Metro Vancouver. (2014). Statistics Overview. Retrieved from http://www.portmetrovancouver.com/docs/default-source/about-facts-stats/2014statistics-overview.pdf?sfvrsn $=0$

Port of Churchill. (n.d.). Port of Churchill [webpage]. Retrieved from http://www.portofchurchill.ca

Port of Thunder Bay. (2015). Port of Thunder Bay Cargo Statistics [webpage]. Retrieved from http://www.portofthunderbay.com/article/port-of-thunder-bay-cargo-statistics-267.asp

Statistics Canada. (2014, January 13). Population and dwelling counts, for Canada, provinces and territories, census divisions, and census subdivisions (municipalities), 2011 and 2006 censuses [data set]. Retrieved from http://www12.statcan.gc.ca/censusrecensement/2011/dp-pd/hlt-fst/pd-pl/TableTableau.cfm?LANG=Eng\&T=304\&PR=62\&S=51\&O=A\&RPP=10\#FootCSDType

Stewart, D.B., \& Lockhart, W.L. (2005). An Overview of the Hudson Bay Marine Ecosystem. Retrieved from Government of Canada, Department of Fisheries and Oceans website: http://www.dfo-mpo.gc.ca/libraries-bibliotheques/toc-tdm/314704-eng.htm

Transport Canada. (2010a, January 20). Arctic Shipping Pollution Prevention Regulations [webpage]. Retrieved from https://www.tc.gc.ca/eng/marinesafety/debs-arctic-actsregulations-asppr-421.htm

Transport Canada. (2010b, June 18). Northern Community Re-supply [webpage]. Retrieved from https://www.tc.gc.ca/eng/marinesafety/debs-arctic-resupply-190.htm

Winnipeg Free Press. (2013, November 22). Port of Churchill [photograph]. Retrieved from http://www.winnipegfreepress.com/business/omnitrax-excluded-from-port-promotion232965391.html

Winnipeg Free Press. (2015, December 1). OmniTrax looking to sell Port of Churchill, Hudson Bay Rail. Retrieved from http://www.winnipegfreepress.com/business/Omnitrax-putsPort-of-Churchill-up-for-sale-359786241.html 


\section{Section B. The Hudson Bay Complex - Ecology and Environment}

\section{Ecology of the Hudson Bay Complex}

5.1. Ecological protection in the Hudson Bay Complex.............................................................. 33

5.2. Ecologically and biologically significant areas in the Hudson Bay Complex.....................34

5.3. Marine Mammals of the Hudson Bay Complex ……….....................................................

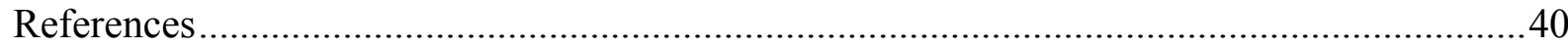

The Government of Canada's Department of Fisheries and Oceans (DFO) has produced five documents which, when added together, present a fairly comprehensive description of the ecology of the Hudson Bay Complex (Stewart and Lockhart, 2005; Stephenson and Hartwig, 2010; Cobb, 2011; Canadian Science Advisory Secretariat (CSAS), 2011; CSAS, 2014a). The ecological information presented in this document will focus on the elements most relevant to the Port of Churchill's marine infrastructure and operations. The DFO documents can be referred to for more information where desired.

\subsection{Ecological protection in the Hudson Bay Complex}

The DFO oversees the management of Canada's coasts and oceans. With the legislation of the Oceans Act in 1997, the Canadian federal government “...made a legal commitment to conserve, protect and develop the oceans in a sustainable manner" (Fisheries and Oceans Canada, 2014a). The Oceans Act also authorized the DFO to "...provide enhanced management to areas of the oceans and coasts which are ecologically and biologically significant" (CSAS, 2011).

Under the Oceans Act, the DFO management policy has been set out in the "Integrated Oceans Management Approach" (Fisheries and Oceans Canada, 2014a). In an effort to identify priority ocean areas and to address conservation issues within them, the DFO has established five Large Ocean Management Areas and is currently "...learning how to apply the integrated management planning approach within these areas" (Fisheries and Oceans Canada, 2014b). The Hudson Bay Complex does not fall within a Large Ocean Management Area (Fisheries and Oceans Canada, 2014c). The DFO has also been creating Marine Protected Areas to protect habitats and species of particular ecological significance. The Hudson Bay Complex does not contain a Marine Protected Area (Fisheries and Oceans Canada, 2014d). However, several Ecologically and Biologically Significant Areas (EBSAs) have been identified in the region (Figure 5.1) (CSAS, 2011), and the identification of EBSAs is a necessary precursor to the creation of Marine Protected Areas (Stephenson and Hartwig, 2010).

The identification of EBSAs does not place any special protection on an area, rather designation is "... a tool to call attention to areas that have particularly high ecological or biological significance to allow appropriate management" (CSAS, 2011). Thus at present, no marine area in the Hudson Bay Complex is receiving special ecological protection through the DFO. However, several migratory bird sanctuaries located in the Hudson Bay Complex (Figure 5.1) receive 
special federal protection through Environment Canada (Environment Canada, 2014). Moreover, Ukkusiksalik National Park, which borders Repulse Bay, and Wapusk National Park, which extends to the coastline just southeast of Churchill, are protected by Parks Canada (Parks Canada, 2008).

\subsection{Ecologically and Biologically Significant Areas in the Hudson Bay Complex}

Ecologically and Biologically Significant Areas were identified as priority areas for enhanced risk-averse management $(C S A S, 2011)$. While EBSAs are created to guide the future development of ocean-related policy and management practices, they can also be used for guidance in assessing the ecological consequences of human activity in an area. As of 2011, 61 EBSAs had been identified in the Canadian Arctic. 13 of these EBSAs can be found in the Hudson Bay Complex. The EBSAs identified in the Hudson Bay Complex provide useful context and information for considering the environmental consequences of the Port of Churchill's present and future shipping operations. It should be noted that EBSA's have also been identified in other Arctic waterways surrounding the Hudson Bay Complex, specifically the Canadian Arctic Archipelago, the Northwest Passage, and western Baffin Bay (CSAS, 2011).

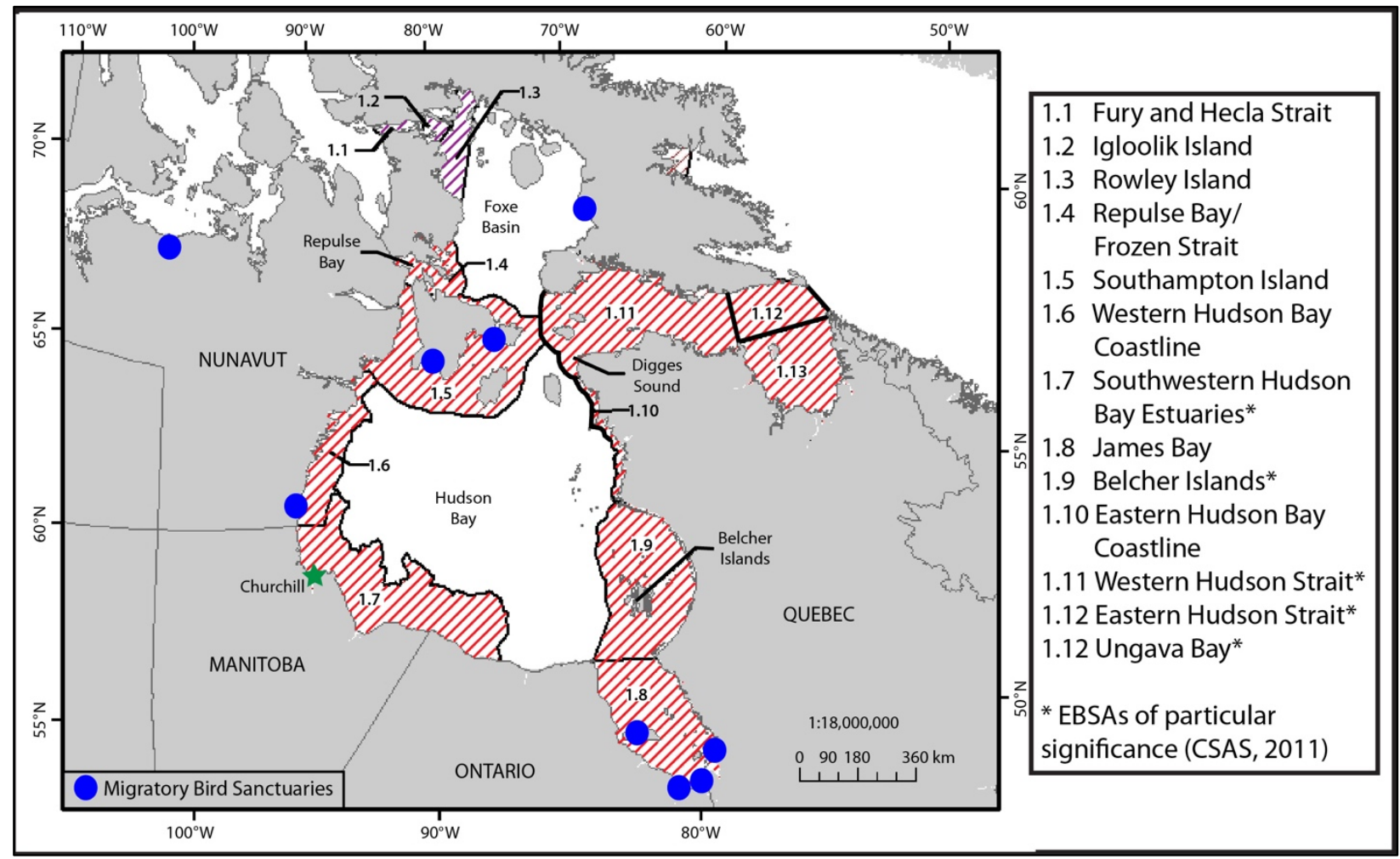

Figure 5.1: Ecologically and Biologically Significant Areas (EBSAs) in the Hudson Bay Complex. EBSAs 1.1 to 1.3 in Northern Foxe Basin were identified in 2010. EBSAs 1.4 to 1.13 were identified in 2011 (CSAS, 2011). Migratory Bird Sanctuaries are also presented (Environment Canada, 2014). 
EBSAs are described based on the particular characteristics that make an area worthy of special designation. These characteristics include "physical feature", "uniqueness", "aggregation", "fitness consequences", and the presence of "rare or endangered species", amongst others. "Physical feature" describes the defining physical characteristic(s) of the area, if any exist. "Uniqueness" outlines the ecological and biological activities occurring in an area that are relatively unique within the greater region. "Aggregations" list any gathering of a particular biological species that is relatively large compared to that species' occurrence in other areas. "Fitness consequences" describes which significant ecological services could be compromised if the ecological viability of an area were lost (CSAS, 2011). The defining characteristics of the EBSAs in the Hudson Bay Complex are listed in Table 5.1 below.

The Port of Churchill is situated within the Southwestern Hudson Bay Estuaries Ecologically and Biologically Significant Area (EBSA) (Section 5.1, Figure 5.1). Grain-carrying vessels using the Port of Churchill travel in and out of this EBSA and pass through the Western Hudson Strait and Eastern Hudson Strait EBSAs. All three of these areas have been identified as EBSAs of particular significance (Canadian Science Advisory Secretariat (CSAS), 2011). The re-supply shipping leaving the Port of Churchill carries cargo along the west coast of Hudson Bay into Kivalliq, passing through the Southwestern Hudson Bay Estuaries EBSA and into the Western Hudson Bay Coastline EBSA. Re-supply vessels stop in several other EBSAs before reaching Churchill and after departing the Kivalliq area.

Some defining characteristics of the three EBSAs traversed by the Port of Churchill's main shipping route (Figure 3.2) are outlined below (CSAS, 2011):

\section{* 1.7. Southwestern Hudson Bay Estuaries}

The stretch of coastline enclosed in this EBSA includes the Seal, Nelson, and Churchill River estuaries. This coastline is an area of high diversity and productivity that provides important habitat to the Western Hudson Bay Polar Bear (listed as "Threatened" in Manitoba) and hosts the world's largest summer aggregations of Beluga whales.

\section{* 1.11. and 1.12. Western and Eastern Hudson Strait}

Hudson Strait is an important migratory corridor for an array of marine mammals. The Strait is a conduit for Arctic waters and experiences periodic intrusions of Atlantic water. Strong currents are common in the Strait, productivity is relatively high, and corals and sponge beds can be found in several places. Both the Western and Eastern Strait are home to colonies of breeding and foraging seabirds in the summer and Bowhead and Beluga whales in the winter. Walrus can be found throughout the Strait at various times of the year, either feeding or at haul out sites.

It should be noted that the ecological influence of shipping activities can extend well beyond the direct line of shipping travel (CSAS, 2014b), and thus EBSAs outside of the Port of Churchill's shipping lines may nonetheless be affected by the shipping activity. 
Table 5.1: Some defining characteristics of the Ecologically and Biologically Significant Areas (EBSAs) in the Hudson Bay Complex. Modified from CSAS (2011).

\begin{tabular}{|c|c|c|c|c|c|}
\hline EBSA & Physical Feature & Uniqueness & Aggregation & $\begin{array}{c}\text { Fitness } \\
\text { Consequences }\end{array}$ & $\begin{array}{c}\text { Rare or Endangered } \\
\text { Species }\end{array}$ \\
\hline $\begin{array}{l}\text { 1.1. Fury and } \\
\text { Hecla Strait }\end{array}$ & - Strong currents & - Migration corridor & - Migration corridor for marine mammals & $\begin{array}{l}\text { - Polar Bear denning } \\
\text { - Bowhead nursery }\end{array}$ & $\begin{array}{c}\text { • Eastern Canada- West } \\
\text { Greenland (ECWG) Bowhead } \\
\text { Whale }\end{array}$ \\
\hline 1.2.Igloolik Island & - Polynya & & $\begin{array}{l}\text { - Migration corridor for marine mammals } \\
\qquad \text { Walrus haul-out sites } \\
\text { - Migration corridor for arctic char }\end{array}$ & $\begin{array}{l}\text { - Walrus feeding } \\
\text { - Bowhead nursery } \\
\text { - Arctic Char feeding }\end{array}$ & - ECWG Bowhead \\
\hline 1.3.Rowley Island & - Sea-ice edge and islands & - Preferred Walrus habitat & $\begin{array}{l}\text { - Migration pathway } \\
\text { - Walrus haul-out sites }\end{array}$ & - Walrus feeding & - ECWG Bowhead \\
\hline $\begin{array}{c}\text { 1.4. Repulse } \\
\text { Bay/Frozen Strait }\end{array}$ & $\begin{array}{c}\text { - Strong currents } \\
\text { - Polynya }\end{array}$ & - Marine mammal summering area & $\begin{array}{c}\text { - Summer marine mammal and seabird } \\
\text { feeding } \\
\text { • Iceland Gull }\end{array}$ & $\begin{array}{l}\text { - Marine mammal and } \\
\text { seabird feeding }\end{array}$ & $\begin{array}{c}\text { • ECWG Bowhead } \\
\text { - Northern Hudson Bay } \\
\text { Narwhal } \\
\text { - Northern Hudson Bay-Davis } \\
\text { Strait Atlantic Walrus }\end{array}$ \\
\hline $\begin{array}{l}\text { 1.5. Southampton } \\
\text { Island }\end{array}$ & - Islands & $\begin{array}{l}\text { - Largest single colony of } \\
\text { Common Eiders in Nunavut }\end{array}$ & $\begin{array}{c}\text { - Migration corridor for marine mammals } \\
\text { - Polar Bear denning area and summer } \\
\text { refugia } \\
\text { - Walrus haul-out sites } \\
\text { Seabird colonies }\end{array}$ & $\begin{array}{l}\text { - Polar Bear denning and } \\
\text { feeding } \\
\text { - Walrus feeding } \\
\text { Seabird nesting and } \\
\text { foraging }\end{array}$ & - ECWG Bowhead \\
\hline $\begin{array}{l}\text { 1.6. Western } \\
\text { Hudson Bay } \\
\text { Coastline }\end{array}$ & $\begin{array}{l}\text { - Consistent frontal zone } \\
\text { - Winter shore lead }\end{array}$ & - Macrophytes (e.g. kelp beds) & $\begin{array}{l}\text { - Arctic Char migration corridor } \\
\bullet \text { Beluga aggregation } \\
\text { - Fall migration areas for Polar Bears }\end{array}$ & - Arctic Char feeding & \\
\hline $\begin{array}{l}\text { 1.7. Southwestern } \\
\text { Hudson Bay } \\
\text { Estuaries* }\end{array}$ & $\begin{array}{l}\text { - Three estuaries } \\
\text { (Churchill, Nelson, and } \\
\text { Seal Rivers) }\end{array}$ & $\begin{array}{c}\text { - World's largest summering } \\
\text { Beluga aggregation } \\
\text { • Harbour seals }\end{array}$ & $\begin{array}{l}\text { - Beluga aggregation } \\
\text { - Polar Bear denning, feeding, and rearing } \\
\text { - High benthic diversity and production }\end{array}$ & $\begin{array}{l}\text { - Polar Bear denning and } \\
\text { feeding } \\
\text { - Beluga aggregation } \\
\text { - High food supply for } \\
\text { benthos }\end{array}$ & $\begin{array}{l}\text { - Western Hudson Bay Beluga } \\
\text { • Ross's Gull } \\
\text { - Western Hudson Bay Polar } \\
\text { Bear (Threatened under } \\
\text { Province of Manitoba) }\end{array}$ \\
\hline
\end{tabular}




\begin{tabular}{|c|c|c|c|c|c|}
\hline $\begin{array}{c}1.8 . \\
\text { James Bay }\end{array}$ & $\begin{array}{l}\text { - Shallow waters } \\
\text { - Lower salinities } \\
\text { - Large estuary }\end{array}$ & $\begin{array}{l}\text { - Supports a variety of warm water } \\
\text { species that are rare or absent in } \\
\text { other eastern Arctic waters } \\
\text { - Summer and wintering Beluga } \\
\text { - Most southerly location used by } \\
\text { Polar Bears in the world } \\
\text { - Eelgrass beds } \\
\text { - International importance for } \\
\text { Hudsonian Godwit and Red Knot }\end{array}$ & $\begin{array}{c}\text { • Walrus haul-out sites and feeding } \\
\bullet \text { Polar Bear denning } \\
\bullet \text { Beluga aggregation } \\
\text { - Cisco and Broad Whitefish migration and } \\
\text { feeding } \\
\text { - Shorebird and waterfowl staging and } \\
\text { feeding } \\
\text { - Seaduck feeding and moulting }\end{array}$ & \begin{tabular}{|} 
- Polar Bear denning and \\
feeding \\
- Walrus haul-out sites \\
and feeding \\
- Shorebird, seaduck, and \\
waterfowl staging and \\
foraging area \\
- Seaduck moulting \\
- Cisco and Broad \\
Whitefish feeding
\end{tabular} & $\begin{array}{c}\text { - Northern Hudson Bay-Davis } \\
\text { Strait Atlantic Walrus } \\
\text { - Eastern Hudson Bay Beluga } \\
\text { - Red Knot subspecies }\end{array}$ \\
\hline $\begin{array}{l}\text { 1.9.Belcher } \\
\text { Islands* }\end{array}$ & $\begin{array}{l}\text { - Polynyas } \\
\text { - Several small estuaries } \\
\text { - Landfast ice around the } \\
\text { islands } \\
\text { - Currents around islands } \\
\text { - Cooler water temperatures } \\
\text { than surrounding Hudson } \\
\text { Bay }\end{array}$ & $\begin{array}{l}\text { - Possible overwintering Beluga } \\
\text { • Eelgrass } \\
\text { - World population of resident } \\
\text { Hudson Bay Common Eider } \\
\text { subspecies }\end{array}$ & $\begin{array}{c}\text { • Walrus haul-out sites } \\
\text { - Summer Beluga aggregation at estuaries } \\
\text { - High benthic diversity and productivity } \\
\bullet \text { Bearded Seals } \\
\text { - Entire world population of resident Hudson } \\
\text { Bay Common Eider subspecies summer and } \\
\text { winter } \\
\text { • Polar Bear feeding }\end{array}$ & $\begin{array}{l}\text { - Polar Bear feeding } \\
\text { - Walrus feeding } \\
\text { - High food supply for } \\
\text { benthos } \\
\text { - Seaduck nesting and } \\
\quad \text { foraging }\end{array}$ & $\begin{array}{c}\text { - Northern Hudson Bay-Davis } \\
\text { Strait Atlantic Walrus } \\
\text { - Eastern Hudson Bay Beluga }\end{array}$ \\
\hline $\begin{array}{l}\text { 1.10. Eastern } \\
\text { Hudson Bay } \\
\text { coastline }\end{array}$ & & & $\begin{array}{c}\text { Migration pathway for Eastern Hudson Bay } \\
\text { Beluga }\end{array}$ & & Eastern Hudson Bay Beluga \\
\hline $\begin{array}{c}1.11 . \\
\text { Western Hudson } \\
\text { Strait* }\end{array}$ & \begin{tabular}{|l} 
- Conduit for arctic waters \\
and periodic intrusions of \\
Atlantic waters \\
- Strong currents \\
Sponge beds
\end{tabular} & -Migration corridor & $\begin{array}{c}\text { - Migration corridor for marine mammals } \\
\text { - Seabird colonies and seaduck nesting and } \\
\text { foraging sites } \\
\text { - Walrus haul-out sites } \\
\bullet \text { Killer-whale } \\
\text { - Overwintering Bowhead and Beluga } \\
\text { Sponge Beds }\end{array}$ & $\begin{array}{l}\text { - Migration corridor to } \\
\text { summer feeding and } \\
\text { nursery grounds for } \\
\text { marine mammals } \\
\text { - Seabird and seaduck } \\
\text { nesting and foraging } \\
\text { - Walrus feeding } \\
\text { Epibenthic habitat }\end{array}$ & $\begin{array}{c}\text { - Western and Eastern Hudson } \\
\text { Bay Beluga } \\
\bullet \text { ECWG Bowhead } \\
\bullet \text { Ivory Gull } \\
\text { Northern Hudson Bay-Davis } \\
\text { Strait Atlantic Walrus }\end{array}$ \\
\hline $\begin{array}{c}1.12 . \\
\text { Eastern Hudson } \\
\text { Strait* }\end{array}$ & $\begin{array}{c}\text { - Conduit for arctic waters } \\
\text { and periodic intrusions of } \\
\text { Atlantic waters }\end{array}$ & - Migration corridor & $\begin{array}{l}\cdot \text { Migration corridor for marine mammals } \\
\cdot \text { Sponges and corals } \\
\cdot \text { Shrimp } \\
\cdot \text { Overwintering Bowhead and Beluga } \\
\cdot \text { Walrus haul-out sites }\end{array}$ & $\begin{array}{l}\text { - Migration corridor to } \\
\text { summer feeding and } \\
\text { nursery grounds for } \\
\text { marine mammals } \\
\text { - Seabird nesting and } \\
\text { foraging } \\
\text { - Epibenthic habitat } \\
\text { - Beluga overwintering } \\
\text { and feeding }\end{array}$ & $\begin{array}{c}\text { - Western and Eastern Hudson } \\
\text { Bay Beluga } \\
\bullet \text { ECWG Bowhead } \\
\bullet \text { Ivory Gull } \\
\text { - Northern Hudson Bay-Davis } \\
\text { Strait Atlantic Walrus }\end{array}$ \\
\hline 1.13.Ungava Bay* & & $\begin{array}{l}\text { Largest number of breeding Thick- } \\
\text { bulled Murres in Canada }\end{array}$ & $\begin{array}{l}\text { • Corals } \\
\text { - Depleted stock of Beluga } \\
\text { - Polar Bear seasonal refugia } \\
\text { - Seabird colonies } \\
\text { - Seaduck nesting }\end{array}$ & $\begin{array}{l}\text { - Seabird and seaduck } \\
\text { nesting and foraging } \\
\text { - Polar Bear breeding, } \\
\text { rearing, and feeding } \\
\text { Epibenthic habitat }\end{array}$ & - Ungava Bay Beluga \\
\hline
\end{tabular}




\subsection{Marine Mammals of the Hudson Bay Complex}

The Hudson Bay Complex is home to a variety of marine mammals at various times of the year, including Bowhead Whale (Balaena mysticetus), Killer Whale (Orcinus orca), Beluga Whale (Delphinapterus leucas), Narwhal (Monodon monoceros), Walrus (Odobenus rosmarus), Ringed Seal (Pusa hispada), Harbour Seal (Phoca vitulina), Bearded Seal (Erignathus barbatus), Harp Seal (Pagophilus groenlandica), and Hooded Seal (Crystophora cristata). The population of each species in the Hudson Bay Complex is thoroughly discussed in a document produced by the DFO in 2010 (Stephenson and Hartwig, 2010). The populations of Beluga, Narwhal, and Bowhead whales in the Hudson Bay Complex are of particular concern and are described in more detail below:

\section{- Beluga}

Several Beluga Whale populations or "stocks" can be found in the Hudson Bay Complex. Beluga Whales in Hudson Bay belong to two stocks (de March and Postma, 2003, Richard, 2010, Lewis et al,. 2009, Turgeon et al., 2009): Western Hudson Bay (WHB) and Eastern Hudson Bay (EHB). The Belugas found in James Bay are believed to belong to a separate stock. The Committee on the Status of Endangered Wildlife in Canada (COSEWIC) has designated the WHB stock as "Special Concern" (COSEWIC, 2004) and the stock is currently being considered for listing under the federal Species at Risk Act (SARA). The Eastern Hudson Bay population is currently listed as "Endangered" (COSEWIC, 2004). These COSEWIC designations imply that the EHB stock is "facing imminent extirpation" while the WHB stock "...may become threatened or endangered because of a combination of biological characteristics and identified threats".

Despite the COSEWIC designation, the WHB stock is currently considered stable. The most recent abundance estimate, performed in 2004, indicated that there were roughly 57,300 belugas at that time (Richard, 2005). The EHB stock, however, declined from roughly 4,200 to roughly 3,030 between 1985 and 2011, when the last assessment was completed (Doniol-Valcroze et al., 2011). The James Bay Beluga population was estimated at 9,292 in 2008 and the stock was determined to be stable at that time (Gosselin et al., 2009).

Beluga whales in the Hudson Bay populations are found in Hudson Bay during the spring and summer and in Hudson Strait during the fall and winter. Whales in the James Bay population remain in the area throughout the year (Stephenson and Hartwig, 2010). The timing of arrival for Beluga whales in Hudson Bay depends on ice conditions. The whales follow ice edges and leads into the bay, arriving in the late spring or early summer (Hobbs et al., 2005). Whales from the Western Hudson Bay population form large aggregations numbering in the tens of thousands in the Churchill, Nelson and Seal River estuaries on the southwest coast of Hudson Bay (Stephenson and Hartwig, 2010). These whales will remain in the estuaries during the summer while birthing takes place (Hobbs et al., 2005). In late summer or early fall, the Hudson Bay Belugas move into deep offshore waters and begin the migration to Hudson Strait, where they spend the colder months (Stephenson and Hartwig, 2010). 


\section{- Narwhal}

The Northern Hudson Bay Narwhal population represents the southernmost distribution of this species in Canada (Richard, 2010). Narwhal in this population can be found throughout Hudson Strait, northern Hudson Bay, and Foxe Basin, though the Hudson Bay Complex's primary Narwhal habitat includes summer habitat just west of Southampton Island and winter habitat at the eastern end of Hudson Strait (Stephenson and Hartwig, 2010). The Northern Hudson Bay stock was surveyed in 1987, 2000, and 2008 (Richard, 2010); the 2008 survey estimated a population size of 610 , less than half of the previous estimates. However, these surveys are subject to significant uncertainty and it has been suggested that the low abundance estimate for 2008 may have been influenced by higher than normal sea-ice cover hindering the ability to detect whales (Westdal, Richard, and Orr, 2013).

\section{- Bowhead}

The Bowhead whales found in Hudson Bay and Foxe Basin belong to the Eastern Canada-West Greenland population (Figure 5.2), which has been listed as of "Special Concern" by COSEWIC (Stephenson and Hartwig, 2010). Important areas for Bowhead whales in the Hudson Bay Complex include the spring nursery in northern Foxe Basin, summer locations in northwestern Hudson Bay, and wintering habitat in Hudson Strait (Stephenson and Hartwig, 2010).

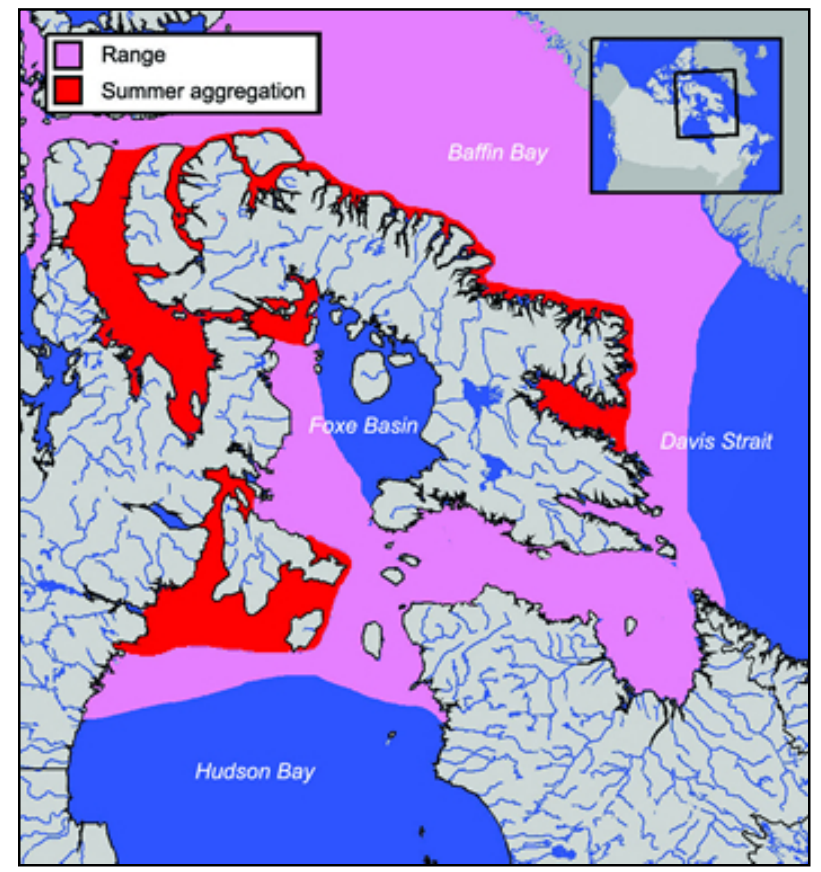

Figure 5.2: Distribution of the Eastern Canada-Western Greenland Bowhead Whale Population. 


\section{References}

Canadian Science Advisory Secretariat (CSAS). (2011, November). Identification of Ecologically and Biologically Significant Areas (EBSA) in the Canadian Arctic. Science Advisory Report 2011/055. Retrieved from Government of Canada, Department of Fisheries and Oceans website: http://www.dfo-mpo.gc.ca/csas-sccs/Publications/SARAS/2011/2011_055-eng.html

Canadian Science Advisory Secretariat (CSAS). (2014a). Identification of Ecologically and Biologically Significant Areas (EBSA) in Northern Foxe Basin, Nunavut. Science Advisory Report 2014/024. Retrieved from Government of Canada, Department of Fisheries and Oceans website: http://www.dfo-mpo.gc.ca/csas-sccs/publications/saras/2014/2014_024-eng.html

Canadian Science Advisory Secretariat (CSAS). (2014b). Shipping Pathway of Effects: An Overview. Science Advisory Report 2014/059. Retrieved from Government of Canada, Department of Fisheries and Oceans website: http://publications.gc.ca/collections/collection_2015/mpo-dfo/Fs70-6-2014-059-eng.pdf

Cobb, D.G. (2011). Identification of Ecologically and Biologically Significant Areas (EBSAs) in the Canadian Arctic. DFO Can. Sci. Advis. Sec. Res. Doc. 2011/070. vi+38p. Retrieved from Government of Canada, Department of Fisheries and Oceans website: http://www.dfo-mpo.gc.ca/Library/344613.pdf

COSEWIC (Committee on the Status of Endangered Wildlife in Canada). 2004. Assessment and update status report on the Beluga Whale Delphinapterus leucas in Canada. Retrieved from the Government of Canada Species at Risk Public Registry website: http://www.sararegistry.gc.ca/document/default_e.cfm?documentID $=410$

de March, B .G.E., and Postma, L.D. 2003. Molecular genetic stock discrimination of belugas (Delphinapterus leucas) hunted in eastern Hudson Bay, northern Quebec, Hudson Strait, and Sanikiluaq (Belcher Islands), Canada, and comparisons to adjacent populations. Arctic 56(2): $111-124$.

Doniol-Valcroze, T, Hammill, M. O. and Lesage, V. 2011. Information on abundance and harvest of eastern Hudson Bay beluga (Delphinapterus leucas). DFO Can. Sci. Advis.Sec. Res. Doc. 2010/121. iv + 13p.

Environment Canada. (2014). Network of Protected Areas [webpage]. Retrieved from Government of Canada, Environment Canada website: https://www.ec.gc.ca/appa/default.asp?lang=En\&n=989C474A-1

Fisheries and Oceans Canada. (2014a). Governance for Sustainable Marine Ecosystems [webpage]. Retrieved from Government of Canada, Department of Fisheries and Oceans website: http://www.dfo-mpo.gc.ca/oceans/management-gestion/integratedmanagementgestionintegree/Governance-eng.htm

Fisheries and Oceans Canada. (2014b). Oceans Planning [webpage]. Retrieved from Government of Canada, Department of Fisheries and Oceans website: http://www.dfompo.gc.ca/oceans/planning/index-eng.htm 
Fisheries and Oceans Canada. (2014c). National Framework for Canada's Network of Marine Protected Areas [webpage]. Retrieved from Government of Canada, Department of Fisheries and Oceans website: http://www.dfo-mpo.gc.ca/oceans/publications/dmpafeczpm/framework-cadre2011-eng.asp\#t1

Fisheries and Oceans Canada. (2014d). Marine Protected Areas [webpage]. Retrieved from Government of Canada, Department of Fisheries and Oceans website: http://www.dfompo.gc.ca/oceans/marineareas-zonesmarines/mpa-zpm/index-eng.htm

Gosselin, J-F., Lesage, V. et Hammill, M.O. 2009. Abundance indices of beluga in James Bay, eastern Hudson Bay and Ungava Bay in 2008. DFO Can. Sci. Advis. Sec. Res. Doc. 2009/006. iv +25 p.

Hobbs, R.C., Laidre, K.L, Vos, D.J., Mahoney, B.A., and Eagleton, M. 2005. Movements and area use of belugas, Delphinapterus leacus, in a subactic Alaskan Estuary. Arctic, 58 (4), 331-340.

Lewis, A, Hammill, M.O., Power M., Doidge, D.W., Lesage, V. 2009. A comparison of eastern Hudson Bay (Delphinapterus leucas) movement and aggregation patterns using satellite telemetry and Nunavik traditional ecological knowledge. Arctic 62(1):13-24

Parks Canada (2008, November 10). National Parks of Canada: National Parks List [webpage]. Retrieved from Government of Canada, Parks Canada website: http://www.pc.gc.ca/progs/np-pn/recherche-search_e.asp?p=1

Richard, P. 2005. An estimate of the Western Hudson Bay beluga population size in 2004. DFO CSAS Res. Doc. 2005/17. ii +29 p.

Richard, P.R. 2010. Stock definition of belugas and narwhals in Nunavut. DFO Can. Sci. Advis. Sec. Res. Doc. 2010/022. iv +14 p.

Stephenson, S.A., and Hartwig, L. (2010). The Arctic Marine Workshop. Freshwater Institute, Winnipeg, Manitoba, February 16-17, 2010. Can. Manuscript Rep. Fish. Aquat. Sci. 2934: vi+67p. Retrieved from Government of Canada, Department of Fisheries and Oceans website: http://publications.gc.ca/site/eng/380744/publication.html

Stewart, D.B., and Lockhart, W.L. (2005). An Overview of the Hudson Bay Marine Ecosystem. Canadian technical report of fisheries and aquatic sciences no. 2586. Retrieved from Government of Canada, Department of Fisheries and Oceans website: http://www.dfompo.gc.ca/libraries-bibliotheques/toc-tdm/314704-eng.htm

Turgeon, J., Duchesne, P., Postma, L. D. and Hammill, M. O. 2009. Spatiotemporal distribution of beluga stocks (Delphinapterus leucas) in and around Hudson Bay: Genetic mixture analysis based on mtDNA haplotypes. DFO Can. Sci. Advis. Sec. Res. Doc. 2009/011. iv $+14 \mathrm{p}$.

Westdal, K. H., Richard, P. R., \& Orr, J. R. (2013). Availability bias in population survey of Northern Hudson Bay narwhal (Monodon monoceros). Polar biology, 36(9), 1235-1241. 


\section{Environment of the Hudson Bay Complex: Climate-related Trends, Variability, and Projections}

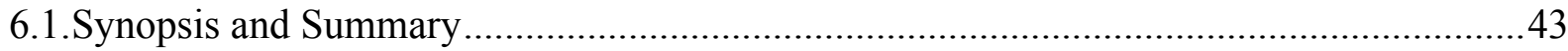

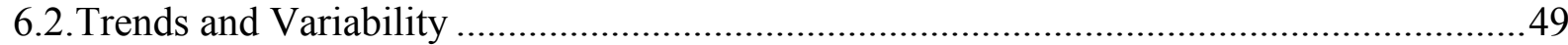

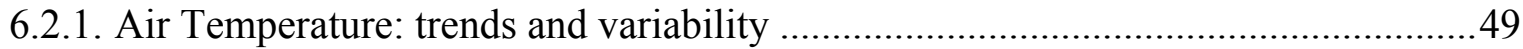

A. Current climatology of the Hudson Bay Complex...................................................49

B. Surface air temperature trends for the land area surrounding the Hudson Bay Complex ...................................................................................................50

C. Trends in surface air temperatures for the ocean area above the Hudson Bay

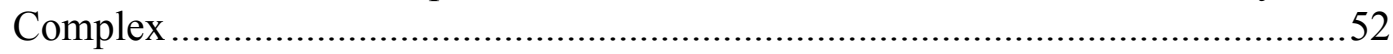

D. Churchill temperature trends...........................................................................54

6.2.2. Sea Ice: trends and variability, and the influence of fresh water on sea ice in the Hudson Bay Complex ......................................................................................56

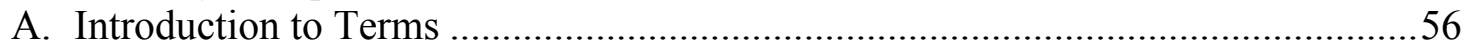

B. An introduction to sea ice in the Hudson Bay Complex........................................57

C. Historical timing of sea ice freeze-up and melt ...................................................59

D. Trends in freeze-up and breakup dates ................................................................61

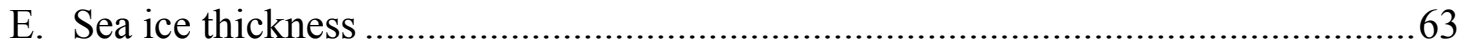

F. The influence of fresh water on sea ice in the Hudson Bay Complex ......................64

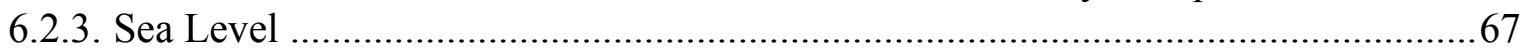

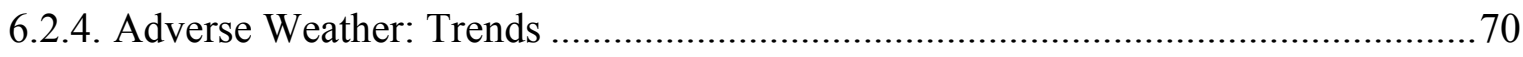

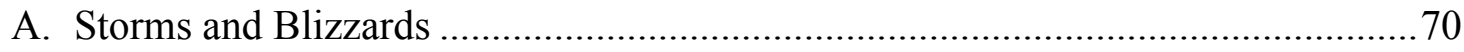

B. Fog, freezing precipitation, and blowing snow................................................... 72

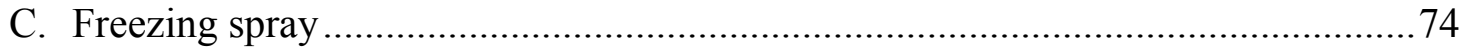

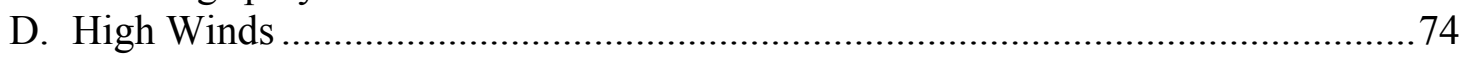

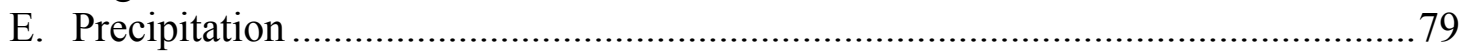

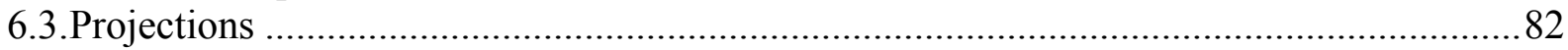

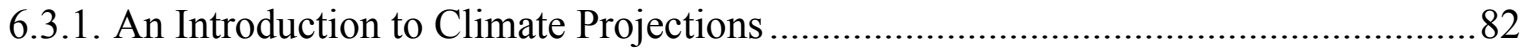

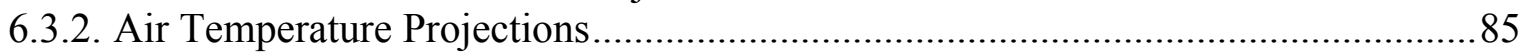

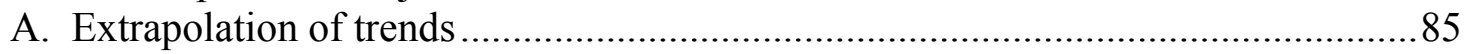

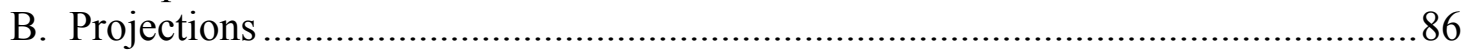

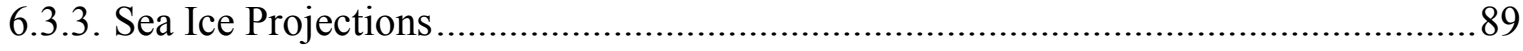

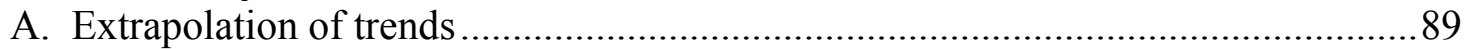

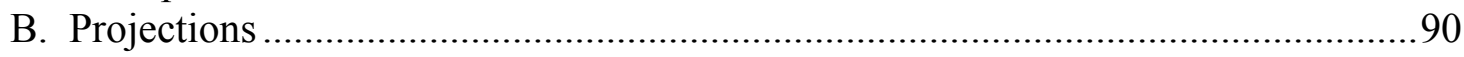

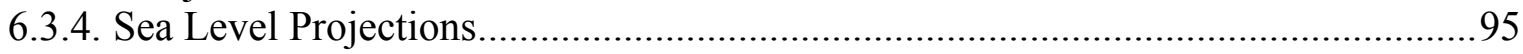

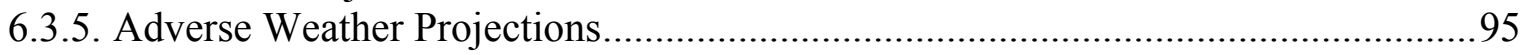

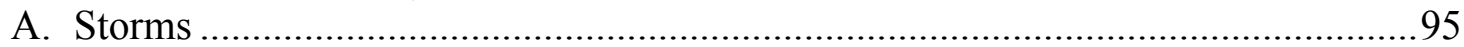

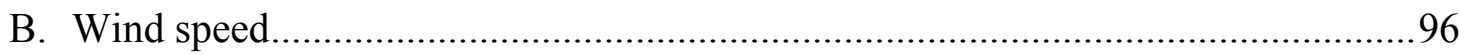

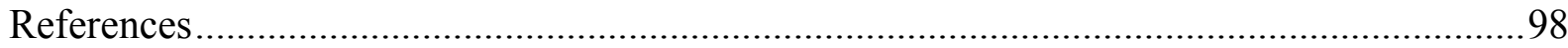




\subsection{Synopsis and Summary}

\section{Synopsis}

The Hudson Bay Complex is a highly dynamic environment undergoing rapid change. The Complex currently experiences surface air temperatures that range from seasonal averages of -30 to $-10^{\circ} \mathrm{C}$ in the winter and 0 to $10^{\circ} \mathrm{C}$ in the summer (NCEP Reanalysis 1 data). These temperatures are warming rapidly in all areas of the Complex, particularly in the fall, where temperatures are rising at rates of up to $1.8^{\circ} \mathrm{C}$ per decade (NCEP Reanalysis 1 data). This warming is expected to continue into the future. For example, some projections are calling for an increase of nearly $1^{\circ} \mathrm{C}$ per decade in the annual average temperature of Hudson Bay between 2012 and 2061 (Steiner et al.., 2013).

At present the entire Hudson Bay Complex is largely ice free during the months of August, September, and October, with the longest open water season occurring in Hudson Strait, followed by Hudson Bay, and Foxe Basin. Sea ice in the Complex is responding to warming temperatures and other forcings; for example, the open water seasons of 1996-2010 versus those of 1980-1995 were on average 3.1 weeks longer in Hudson Bay, 3.5 weeks longer in Foxe Basin, and 4.9 weeks longer in Hudson Strait between 1980 and 2010 (Hochheim and Barber, 2014). Looking towards the future, climate projections comparing 2041-2070 with 1961-1990 predict that freeze-up could be delayed by 25 days in Hudson Bay and 31 days in Foxe Basin, that breakup could occur 24 days earlier in Hudson Bay and 22 days earlier in Foxe Basin, and that Hudson Strait will become essentially ice free during December and June (Joly et al., 2011).

Sea level in the Hudson Bay Complex declined significantly due to isostatic rebound until as recently as 1985, but the influence of increasing sea levels as a result of climate change appears to have balanced out this decline in some areas and slowed it in others (Gough and Robinson, 2000). For example, no major change of average sea level is expected by 2030 or 2050 for the Churchill area. The shorter time-scale, seasonal variation in sea level in the Churchill area is not particularly well understood. This short-term sea level fluctuation is known to vary in response to river discharge and hydroelectric regulation (Gough, Robinson, and Hosseinian, 2005). Both these factors will likely change in the future but the direction and magnitude of their effect on seasonal sea level variation is as yet unclear.

The trends and projections for adverse weather are not as clear as those for temperature and sea ice. Storms are most frequent, intense, and lengthy in the Hudson Bay Complex during the "storm season" of August to December (Savard et al., 2014). Although climate models comparing the 2041-2070 period with the 1961-2000 period are not predicting an increase in annual average storminess, more storm activity is projected for the months of December and January (Savard et al., 2014), as the "storm season" appears to be extending into the winter in response to longer open water conditions. Freezing precipitation, meanwhile, is responding in highly variable fashion to changes in climate while the frequencies of fog and blowing snow are largely declining in the Complex (Hanesiak and Wang, 2005). Finally, average winds are 
strongest in the fall in the Complex and several locations have experienced significant increases in average annual, seasonal, or monthly wind speeds between 1970 and 2011 (Environment Canada, 2013b).

The environment around the Port of Churchill has experienced similar changes to those observed in the Hudson Bay Complex. The average temperature increased by $0.61{ }^{\circ} \mathrm{C}$ per decade in the summer, $0.56^{\circ} \mathrm{C}$ per decade in the fall, and $0.64^{\circ} \mathrm{C}$ per decade in the winter between 1970 and 2014 (Environment Canada data). Although little significant change occurred in monthly average snow and rain fall between 1970 and 2012, there was an observable tendency for more days with precipitation and increasing daily precipitation earlier in the shipping season, and the opposite for the later months of the shipping season, between 1970 and 2014 (Environment Canada data). Finally, with regard to winds, Churchill had an annual average wind speed of $21.2 \mathrm{~km} \mathrm{~h}^{-1}$ which rose at a rate of $0.290 \mathrm{~km} \mathrm{~h}^{-1}$ per decade between 1970 and 2011. Average spring wind speed also rose during that time frame at a rate of $0.506 \mathrm{~km} \mathrm{~h}^{-1}$ per decade (Environment Canada, 2013b). Moreover, the number of days per month or shipping season with wind speeds reaching or exceeding critical thresholds of 30 and $50 \mathrm{~km} \mathrm{~h}^{-1}$ tended to increase between 1970 and 2011 in Churchill (Environment Canada data).

\section{Summary of trends and projections}

A summary of the climate trends and projections described in sections 6.2 and 6.3 is provided below.

\section{A. Temperature}

Trends and variability:

- Current surface air temperatures in the Hudson Bay Complex:

- Temperatures typically decline from south to north in the Hudson Bay Complex and average seasonal temperatures vary between 0 and $10^{\circ} \mathrm{C}$ in the summer and 10 and $-30^{\circ} \mathrm{C}$ in the winter (results computed using NCEP "Reanalysis 1 " data).

- Surface air temperatures over the land surrounding the Hudson Bay Complex between 1980 and 2010:

- Temperatures increased by 0.8 to $1.5^{\circ} \mathrm{C}$ per decade in the fall and by 0.5 to $0.8^{\circ} \mathrm{C}$ in the spring (Hochheim and Barber, 2014).

- Surface air temperatures over the ocean between 1979 and 2013:

- The entire Hudson Bay Complex displayed significant warming trends during summer and fall, and Foxe Basin displayed positive trends for each season. Warming was most rapid in each area during fall. Significant positive trends varied from 0.5 to $1.8^{\circ} \mathrm{C}$ per decade, corresponding to a total warming of 1.7 to $6.12^{\circ} \mathrm{C}$ between 1979 and 2013 (results computed using NCEP "Reanalysis 1" data).

- Churchill temperature trends between 1970 and 2014: 
- Annual average temperature increased at a rate of $0.5^{\circ} \mathrm{C}$ per decade. Every season except for spring exhibited a significant warming trend; the trends for summer, fall, and winter ranged from 0.56 to $0.64^{\circ} \mathrm{C}$ per decade, corresponding to a total warming in average seasonal temperature of 2.46 to $2.82^{\circ} \mathrm{C}$ between 1970 and 2014.

- The average temperature for all months except April and May was warmer in 1990-2014 than in 1970-1990.

- Results computed using weather station data from Environment Canada.

Projections:

- Extrapolation:

- Increases of 1.2 to $2.3^{\circ} \mathrm{C}(2015-2030)$ and 2.8 to $5.3^{\circ} \mathrm{C}(2015-2050)$ for the fall and spring in the land area surrounding Hudson Bay and Hudson Strait (results used for extrapolation obtained from Hochheim and Barber (2014)).

○ Increases of 1.5 to $2.4^{\circ} \mathrm{C}(2015-2030)$ and 3.5 to $5.6^{\circ} \mathrm{C}(2015-2050)$ for the fall and winter in the surface air temperatures above the waters of Hudson Bay and Foxe Basin (results used for extrapolation produced by analysis of NCEP Reanalysis 1 data).

- Increases of $0.8^{\circ} \mathrm{C}(2015-2030)$ and $1.8^{\circ} \mathrm{C}$ (2015-2030) in Churchill's annual average temperature, and increases of $1.0^{\circ} \mathrm{C}(2015-2030)$ and $2.2^{\circ} \mathrm{C}(2015-2030)$ in Churchill's average winter temperature (results used for extrapolation produced by analysis of Environment Canada weather station data).

- Climate model projections:

- Increases in surface air temperature of nearly $1^{\circ} \mathrm{C}$ per decade are projected for Hudson Bay between 2012 and 2061 (Steiner et al., 2013), corresponding to a temperature rise of roughly $4.7^{\circ} \mathrm{C}$ by 2061 .

- A mean change in annual average temperature of $+3.9^{\circ} \mathrm{C}$ for $2041-2070$ versus 1961-1990 is projected for the Hudson Bay Complex. Projected monthly changes range from $+0.8^{\circ} \mathrm{C}$ for July to $+10^{\circ} \mathrm{C}$ for December (Joly et al., 2011).

\section{B. Sea Ice}

* Trends and variability:

- Sources: Hochheim and Barber (2014); Hochheim, Barber, and Lukovich (2010); Canadian Coast Guard (2012).

- Hudson Bay:

- Current freeze-up: late October to early December.

- Current breakup: late May to early August.

- Underwent an average extension of 3.1 weeks in the open water season for 19962010 vs. $1980-1995$.

- Foxe Basin:

○ Freeze-up: mid-October to mid-November. 
- Breakup: mid-June to mid-September

- Underwent an average extension of 3.5 weeks in the open water season for 19962010 vs. 1980-1995.

- Hudson Strait:

- Freeze-up: mid-November to early December.

- Breakup: May to early July.

- Underwent an average extension of 4.9 weeks in the open water season for 19962010 vs. $1980-1995$.

- There is significant correlation between fall surface air temperatures and both freeze-up dates and late-fall sea ice extent. Variation in spring sea ice extent and breakup dates are linked with fall and spring surface air temperatures and spring wind strengths (Hochheim and Barber, 2014).

- Fresh water may have a sizeable influence on sea ice formation and persistence in Hudson Bay, in estuaries, near shore, and in the open water area (Gough, Robinson, and Hosseinian, 2005). River input is a major determinant of the variation in freshwater concentration in the Bay (St-Laurent et al., 2011) and input volumes and timing are a product of both climate and hydroelectric regulation (Déry et al., 2011).

- A better understanding of the factors controlling freeze-up in the Churchill River estuary could be especially valuable for the Port of Churchill. Churchill River discharge is influenced by climate and hydrological regulation. More investigation is required to understand the interplay between these two factors, river discharge, and ice in the estuary.

Projections:

- Extrapolation:

$\circ$ Increases in the open water season length of 2.1,2.3, and 3.3 weeks by 2030 and 4.1, 4.7, and 6.5 weeks by 2050 in Hudson Bay, Foxe Basin, and Hudson Strait, respectively (results used for extrapolation obtained from Hochheim and Barber, 2014).

- Climate model projections:

○ 2041-2070 vs. 1961-1990 (Joly et al., 2011):

- Freeze-up is projected to be delayed by 25 days in Hudson Bay and 31 days in Foxe Basin. Breakup is projected to occur 24 days earlier in Hudson Bay and 22 days earlier in Foxe Basin. Hudson Strait is projected to be essentially ice free during December and June.

- Sea ice volume is projected to be significantly lower throughout the shorter ice season.

- Sea ice thickness is predicted to decline by $20-60 \%$, with the greatest declines in south-western Hudson Bay, James Bay, and Hudson Strait. 


\section{Sea Level}

* Trends and variability:

- Tidal sea level change in Churchill averaged roughly $3000 \mathrm{~mm}(3 \mathrm{~m})$ between high and low tide for the time period 2005 to 2015 (result computed by analysis of data from Fisheries and Oceans Canada).

- Long term sea level declined at Churchill by roughly $550 \mathrm{~mm}(55 \mathrm{~cm})$ between 1940 and 1985 in response to isostatic rebound, but has been more-or-less level since 1986. It has been suggested that the influence of climate change is now offsetting isostatic rebound in the area (Gough and Robinson, 2000).

- Sea level varies $300-350 \mathrm{~mm}$ on a seasonal time scale in response to river discharge into Hudson Bay (Gough, Robinson, and Hosseinian, 2005). It has been suggested that sea level in Churchill may have been influenced by the diversion of the Churchill River in 1976 (Gough and Robinson, 2000).

\section{Projections:}

- Projections for long-term sea level variation:

- The Port of Churchill is unlikely to experience significant changes in long-term sea level by 2030 or 2050 .

- Projections for short-term sea level variation:

- Changes may occur in the timing and magnitude of short-term sea level variations at the Port of Churchill and in Hudson Bay in response to climate change and hydroelectric activity (Gough, Robinson, and Hosseinian, 2005). However, there is significant uncertainty surrounding these changes and no predictions for short-term sea level variation in Hudson Bay could be found in the scientific literature.

\section{Adverse Weather}

Trends and variability:

- Storms and blizzards:

- Storms occur most frequently and are at their longest and most intense in the late summer and fall (August to December) (Savard et al., 2014).

- Fall months (September to November) typically average 2.5 storms per month while summer months average closer to 2 storms per month (Gachon et al., 2011).

- Fog, freezing precipitation, and blowing snow (Hanesiak \& Wang, 2005):

- Fog events appear to be largely declining in most seasons and areas.

- Trends in the frequency of freezing precipitation are quite variable.

- The incidence of blowing snow is largely declining.

- Winds:

- Winds tend to be weakest in the summer and strongest in the fall and early winter. Monthly average wind speeds typically range between 15 and $25 \mathrm{~km} \mathrm{~h}^{-1}$ in the Hudson Bay Complex. Several weather stations in the Complex have recorded increasing trends in annual, seasonal, or monthly average wind speed, and no 
negative trend was found (results produced by analysis of data from Environment Canada (2013b)).

- With regards to Churchill specifically, wind speeds are highest in September, October, and November and appear to be increasing over time. Data analysis suggests an increase between 1970 and 2011 in the frequency of days per month and shipping season with wind speeds greater than or equal to thresholds of 30 , 40,50 , and $60 \mathrm{~km} \mathrm{~h}^{-1}$ (results produced by analysis of weather station data ordered from Environment Canada).

- Precipitation:

- Precipitation occurs on roughly half (49\%) of the days of the shipping season.

- Few significant trends were found in monthly average rainfall, snowfall, and total precipitation for Churchill. However, an examination of total precipitation data for 1970-2014 indicates that there has been a tendency towards more days with precipitation and more total precipitation in the earlier months of the shipping season, while the opposite appears true for the later months of the season (results produced by analysis of data ordered from Environment Canada).

* Projections:

- Storms in 2041-2070 vs. 1961-2000 (Savard et al., 2014):

- No significant change is predicted for the average annual number of cyclone centres in the Hudson Bay Complex.

- Models predict a $25 \%$ increase in the number of cyclone centres, an increase in the number of cyclone trajectories, and an increase in the residence time of cyclones during the months of December and January. This may be in response to the extension of the open water season into December.

- Winds

- Average wind speed is projected to increase throughout the Hudson Bay Complex from 1961 to 2100 (Steiner et al., 2013). 


\subsection{Trends and Variability}

This section contains a number of terms that may not be familiar to members of the audience. Words and terms that are indicated in bold are defined in the glossary at the end of this document (section D).

\subsubsection{Air Temperature Trends and Variability}

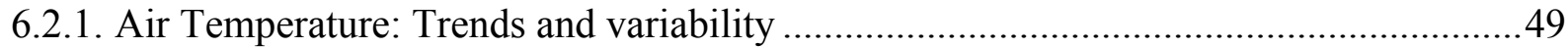

A. Current climatology of the Hudson Bay Complex...............................................49

B. Surface air temperature trends for the land area surrounding the Hudson Bay Complex 50

C. Trends in surface air temperatures for the ocean area above the Hudson Bay Complex .52

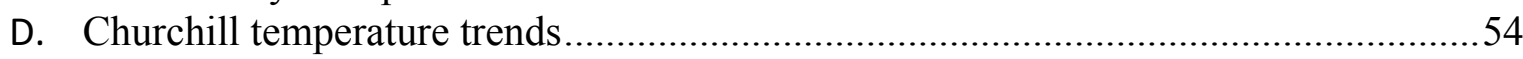

\section{A. Current climate of the Hudson Bay Complex}

There are no thorough and consistent historical datasets for air temperatures over the ocean area of the Hudson Bay Complex. However, it is possible to get a sense for these temperatures using reanalysis datasets. In this section we present the results produced by analyzing surface air temperature data from the National Centers for Environmental Prediction (NCEP) "Reanalysis 1 " dataset. Because there have been so few temperature measurements over the waters of the Hudson Bay Complex, it is difficult to gauge the accuracy of this analysis. Nonetheless, the NCEP data allows us to get a rough idea of the historical surface air temperatures over the Hudson Bay Complex.

The seasonal climatology (1979-2013) of surface air temperatures over the Hudson Bay Complex from NCEP reanalysis data is presented below in Figure 6.1. Here, and throughout this document unless otherwise noted, seasons are defined as follows:

- Winter - January, February, and March (JFM)

- Spring - April, May, and June (AMJ)

- Summer - July, August, and September (JAS)

- Fall - October, November, and December (OND) 


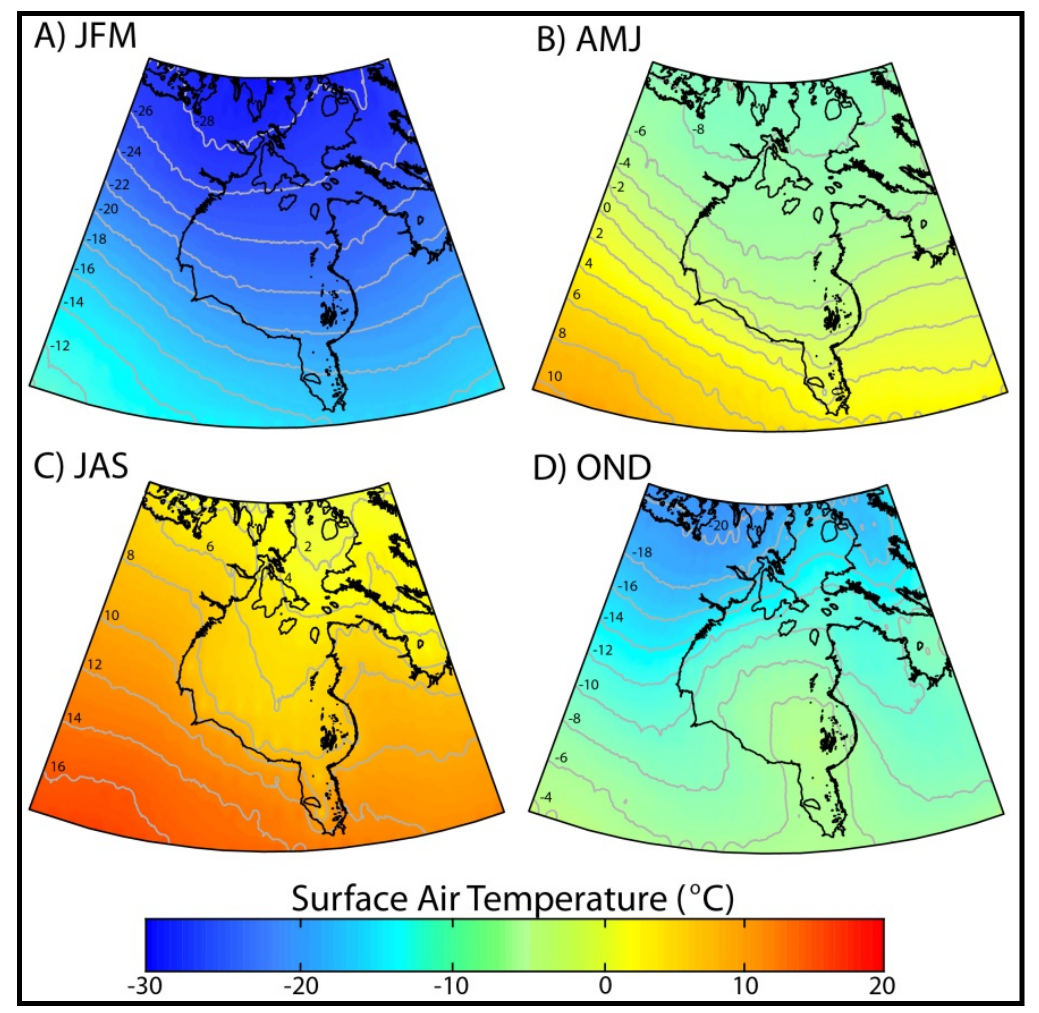

Figure 6.1: Average seasonal surface air temperatures for the Hudson Bay Complex between 1979 and 2013 according to NCEP reanalysis data

The average seasonal temperatures displayed in Figure 6.1 indicate a tendency towards warmer temperatures in the southwest of the Hudson Bay Complex and colder temperatures in the northeast. Figure 6.1 also demonstrates the large intra-annual variation in temperature in the Hudson Bay Complex, as temperatures over the ocean vary between 0 and $10^{\circ} \mathrm{C}$ in the summer but fall more than 20 degrees to between -30 and $-10^{\circ} \mathrm{C}$ in the winter.

\section{B. Surface air temperature trends for the land area surrounding the Hudson Bay Complex}

Hochheim and Barber (2014) recently completed an in depth re-examination of temperature and sea ice trends in Hudson Bay. The authors used terrestrial surface air temperatures for their examination of temperature trends for the Hudson Bay area due to the lack of thorough and consistent historical datasets for air temperature over the ocean. Temperature trends and anomalies were computed using monthly temperature measurements running from 1950 to 2010, obtained from environment Canada's CANGRD data set (Hochheim and Barber, 2014). The analysis was completed using sophisticated statistical methods that will not be described here, but descriptions can be found in the original article. The results are outlined below: 


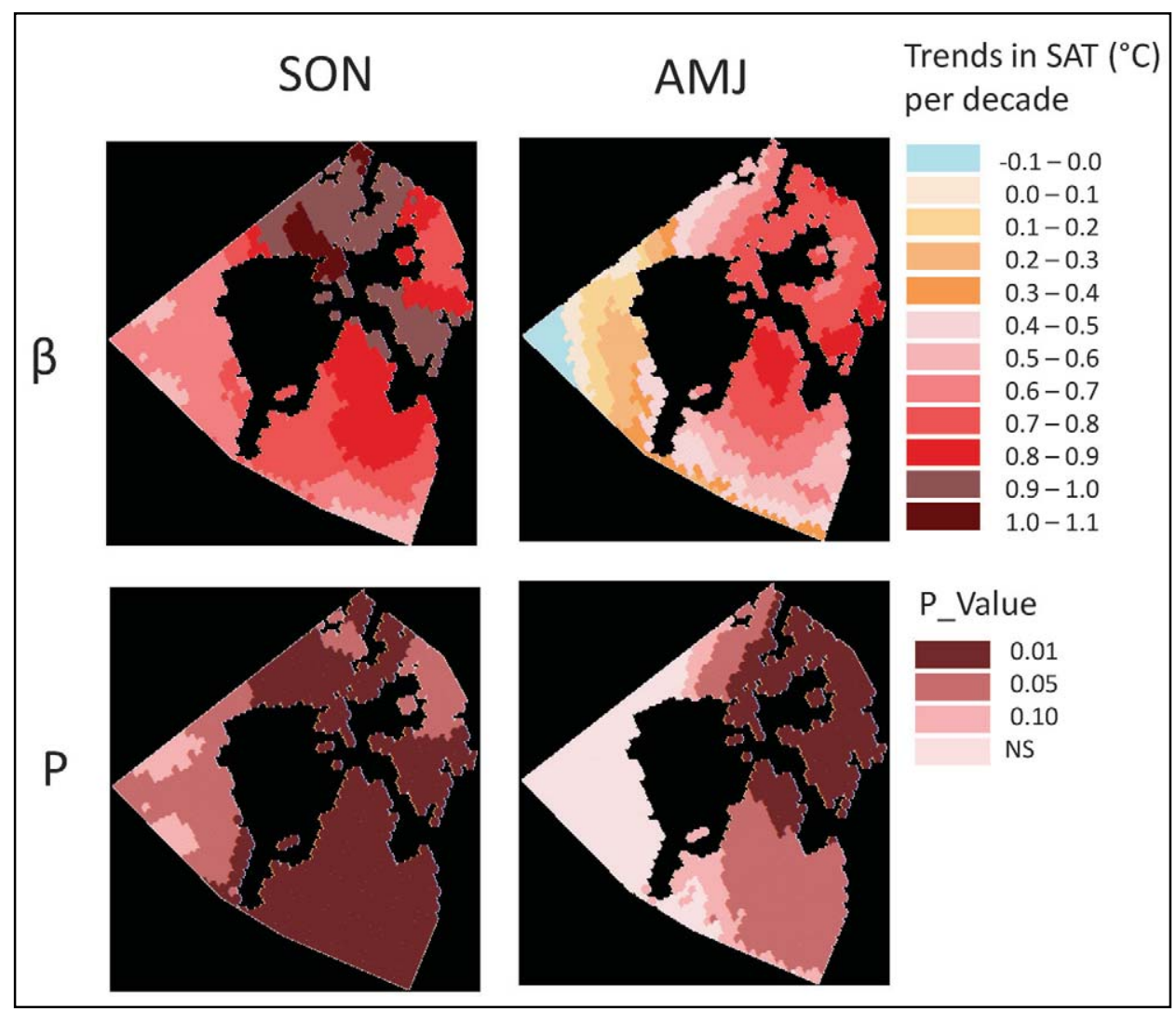

Figure 6.2: The top two maps show the mean change per decade in seasonal surface air temperature $(\beta)$ between 1980 and 2010, for the fall (Sep-Oct-Nov or SON) and spring (Apr-May-Jun or AMJ) seasons. The bottom two maps illustrate statistical significance (p) at 99, 95 and 90\% confidence levels. From Hochheim and Barber (2014).

Figure 6.2 illustrates the significant changes in surface air temperature occurring on the land surrounding the Hudson Bay Complex between 1980 and 2010. This significance is in fact illustrated by the $p$-values in Figure 6.2, where all but the lightest colour in the bottom two maps illustrate statistically significant trends. As can be seen in the figure, the warming trends shown in the top two maps were all found to be significant with the exception of the southern areas in the spring.

As can be seen in Figure 6.2, warming trends in the fall (Sept-Oct-Nov) are strongest in the northern areas of the Hudson Bay Complex, reaching 0.8 to $1^{\circ} \mathrm{C}$ per decade, while trends in the southern Bay are between 0.6 and $0.8^{\circ} \mathrm{C}$ per decade. In the spring (April-May-June), warming trends are again stronger to the north but these trends are smaller than those observed during the fall.

According to Hochheim and Barber (2014), terrestrial surface air temperatures have increased throughout the entire Hudson Bay Complex when temperatures from 1996-2010 are compared with those from 1980-1995. More detailed results from this research are outlined below:

Fall: 
- Between 1980 and 2010 the mean regional warming trend is roughly $0.8^{\circ} \mathrm{C}$ per decade for Hudson Bay, $1.5^{\circ} \mathrm{C}$ per decade for Hudson Strait, and $0.9^{\circ} \mathrm{C}$ per decade for Foxe Basin.

- In a comparison of surface air temperatures from 1996-2010 with those from 1980-1985, the mean surface air temperature increase was $1.5^{\circ} \mathrm{C}$ for Hudson Bay, $2.9^{\circ} \mathrm{C}$ for Hudson Strait, and $1.9^{\circ} \mathrm{C}$ for Foxe Basin.

Spring:

- Between 1980 and 2010 the mean regional warming trend is roughly $0.82^{\circ} \mathrm{C}$ per decade for Hudson Strait, and $0.5^{\circ} \mathrm{C}$ for Foxe Basin. Hudson Bay shows high inter-annual variability and no clear trend between 1980 and 2010.

- In a comparison of surface air temperatures from 1996-2010 with those from 1980-1985, the mean surface air temperature increase was $0.8^{\circ} \mathrm{C}$ for Hudson Bay, $1.6^{\circ} \mathrm{C}$ for Hudson Strait, and $0.9^{\circ} \mathrm{C}$ for Foxe Basin.

In the fall data for each region, there is a notable inflection point in the surface air temperatures for the early 1990s as temperatures begin to rise at a more rapid pace. A somewhat lesspronounced inflection point can be seen in the spring for each region, as temperatures begin to rise more rapidly in the late 1980s (Hochheim \& Barber, 2014).

\section{Trends in surface air temperatures for the ocean area above the Hudson Bay Complex}

Trends in seasonal temperatures in the Hudson Bay Complex produced by analysis of NCEP Reanalysis 1 data:

Underlying the seasonal climatology shown at the beginning of this section in Figure 6.1 are positive trends in average seasonal surface air temperatures. These seasonal trends are presented below in Figure 6.3 and Table 6.1. 

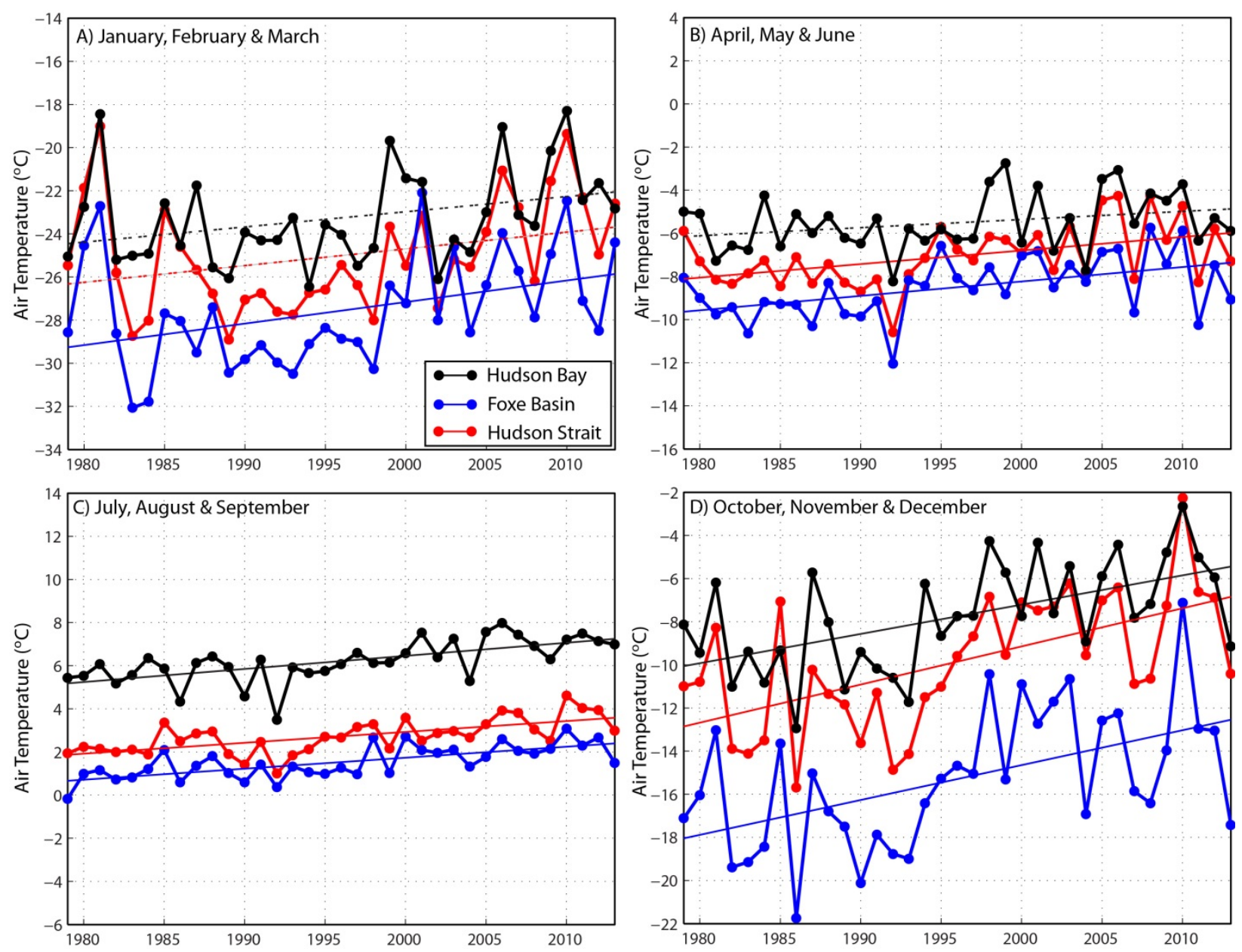

Figure 6.3: The seasonal surface air temperatures for Hudson Bay (black), Foxe Basin (blue), and Hudson Strait (red), for 1979 to 2013. Trends are indicated with a solid or dotted line, where solid lines indicate significant trends $(\mathrm{p}<0.05)$.

Table 6.1: Seasonal surface air temperature trends $\left({ }^{\circ} \mathrm{C} \mathrm{yr}^{-1}\right)$ for the period of 1979 to 2013 over the Hudson Bay Complex from NCEP reanalysis data. Significant trends, computed with $95 \%$ confidence levels, are indicated with an asterisk $(*)$.

\begin{tabular}{|l|l|l|l|l|}
\hline & JFM & AMJ & JAS & OND \\
\hline Hudson Bay & 0.07 & 0.04 & $0.06^{*}$ & $0.14^{*}$ \\
\hline Hudson Strait & 0.08 & $0.06^{*}$ & $0.05^{*}$ & $0.18^{*}$ \\
\hline Foxe Basin & $0.10^{*}$ & $0.07^{*}$ & $0.05^{*}$ & $0.16^{*}$ \\
\hline
\end{tabular}

As can be seen in Figure 6.3 and Table 6.1, NCEP reanalysis data suggest that each area of the Hudson Bay Complex exhibits seasonal warming trends between 1979 and 2013. All regions of the Complex displayed significant warming trends during summer and fall, and Foxe Basin underwent significant warming in all seasons. Warming is most rapid in each region during fall. Significant positive trends vary from 0.05 to $0.18^{\circ} \mathrm{C} /$ year, which over the 34 year study period (1979 to 2013) corresponds to a total warming of 1.7 to $6.12^{\circ} \mathrm{C}$. For example, analysis of NCEP Reanalysis data suggests that a total warming of $6.12^{\circ} \mathrm{C}$ took place in average fall temperatures for Hudson Strait between 1979 and 2013. 


\section{Churchill Temperature Trends}

Environment Canada weather stations have been taking regular surface air temperature recordings in Churchill since at least 1953 (Environment Canada, 2014). Figure 6.4 shows the annual average of temperatures measured at weather station Churchill A between 1970 and 2014. These temperatures display a statistically significant warming trend of roughly $0.5^{\circ} \mathrm{C}$ per decade over the 44 year timeframe. This trend corresponds to a warming of $2.17^{\circ} \mathrm{C}$ in Churchill's annual average temperature from 1970 to 2014.

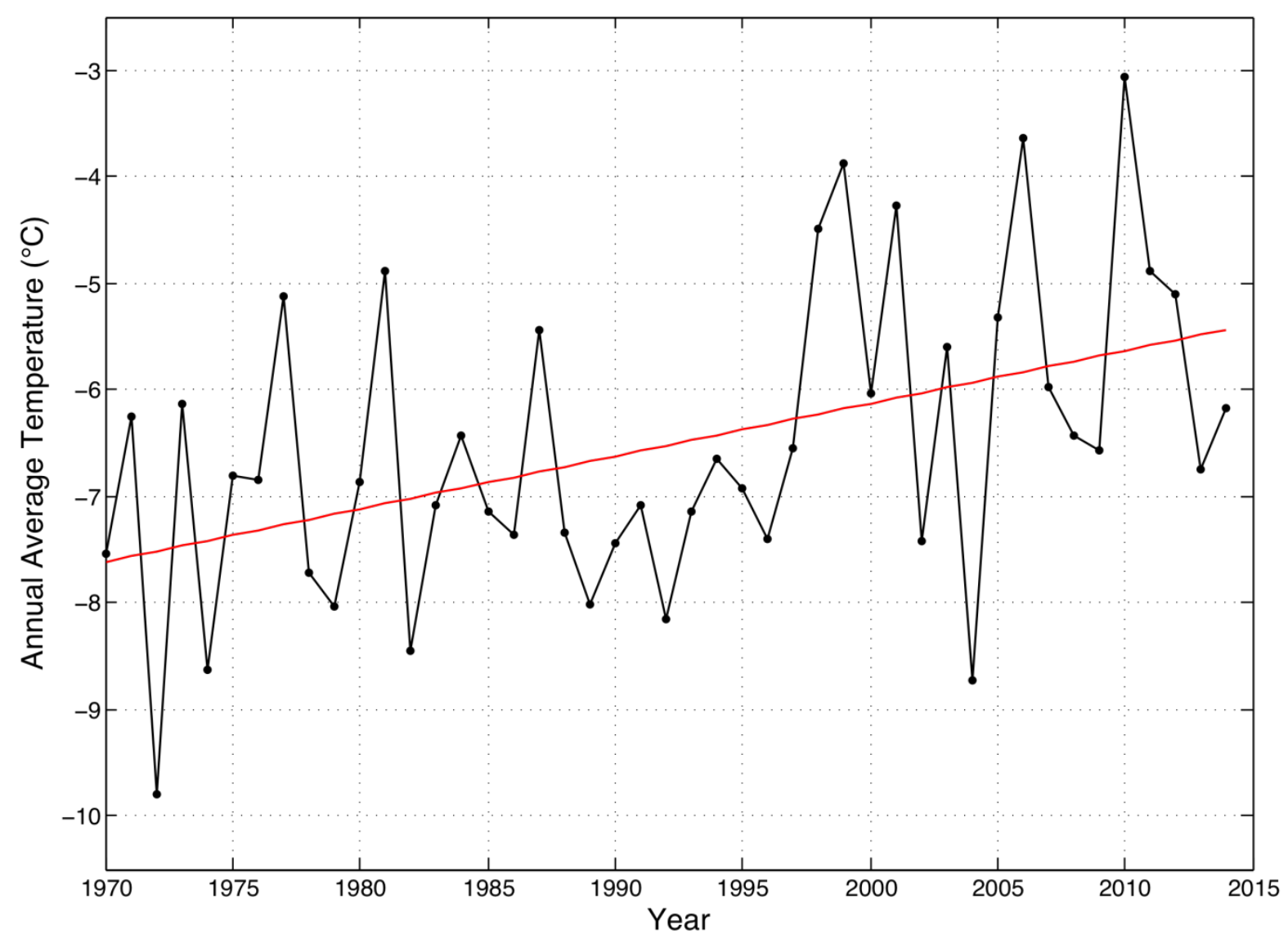

Figure 6.4: The annual average air temperature at weather station Churchill A between 1970 and 2014. The significant $(\mathrm{p}<0.05)$ linear trend is displayed and corresponds to a warming of $0.05^{\circ} \mathrm{C}$ per year. Significance was computed at the $95 \%$ confidence level. Data for weather station "Churchill A" was obtained from Environment Canada (Environment Canada, 2014).

While the annual average air temperature is clearly trending upwards in Churchill, there is some variation in the temperature changes exhibited by the different seasons and months. Figure 6.5 shows the average seasonal temperatures in Churchill from 1970 to 2014. As can be seen in the figure, every season except for spring exhibited a statistically significant warming trend. The trends for summer, fall, and winter are all fairly uniform, ranging from 0.56 to $0.64^{\circ} \mathrm{C}$ per decade, which corresponds to a total warming in average seasonal temperature of 2.46 to $2.82^{\circ} \mathrm{C}$ over the 44 year period. 


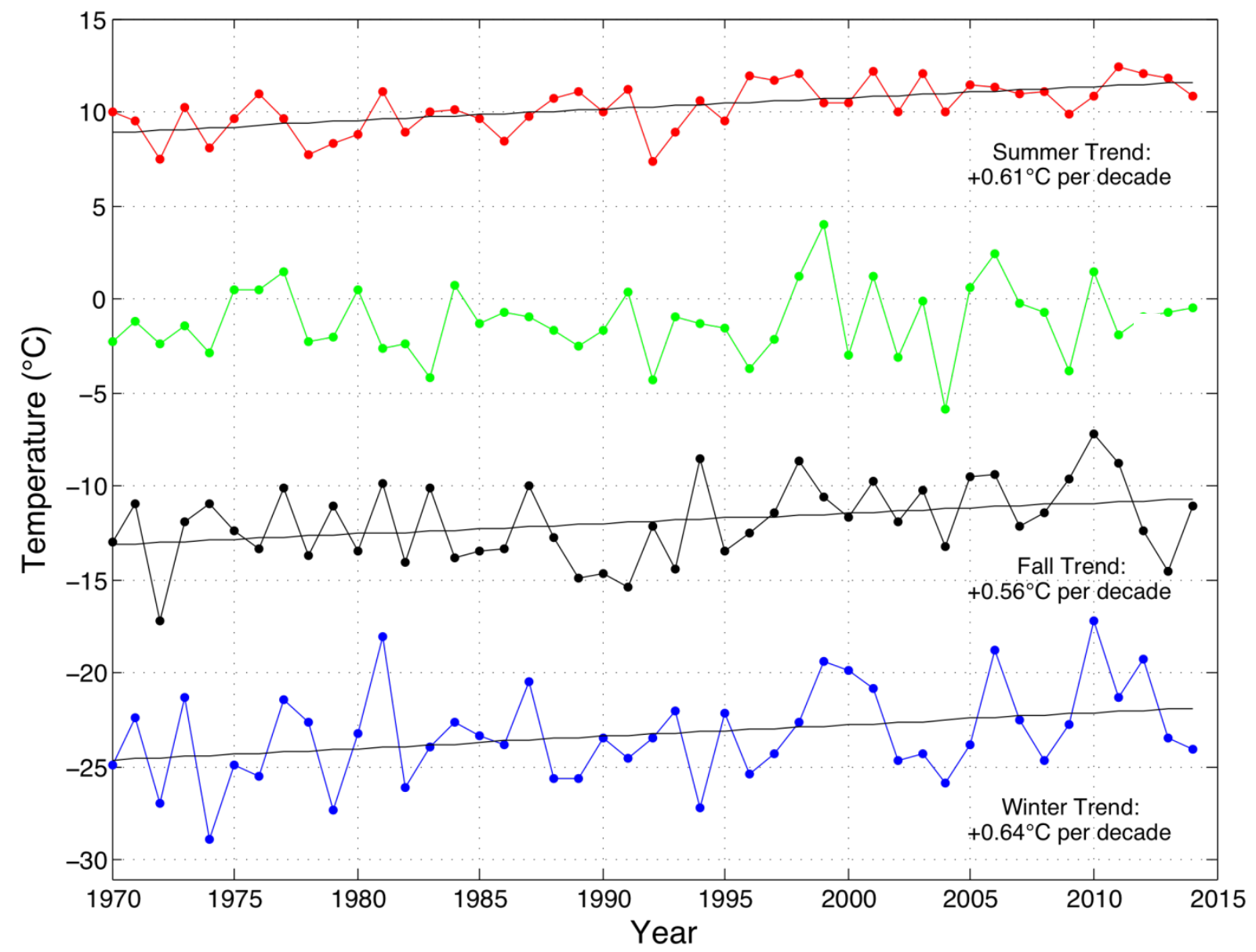

Figure 6.5: Average seasonal surface air temperatures in Churchill between 1970 and 2014 for Summer (JAS - red), Spring (AMJ - green), Fall (OND- black) and Winter (JFM - Blue). Seasonal averages were computed from monthly averages available from Environment Canada (Environment Canada 2014).

Significant trends ( $p<0.05$ at the $95 \%$ confidence level) are indicated with black lines where applicable.

The average temperature for each month for the periods 1970-1990 and 1990-2014 are displayed and compared in Figure 6.6. The figure indicates that the average temperature for all months except April and May was warmer for 1990-2014. December exhibited the greatest temperature difference between the two time periods, with an increase of over $2^{\circ} \mathrm{C}$, and the average temperature for all but 3 months (April, May, and November) increased by $1{ }^{\circ} \mathrm{C}$ or more (Figure 6.6). 

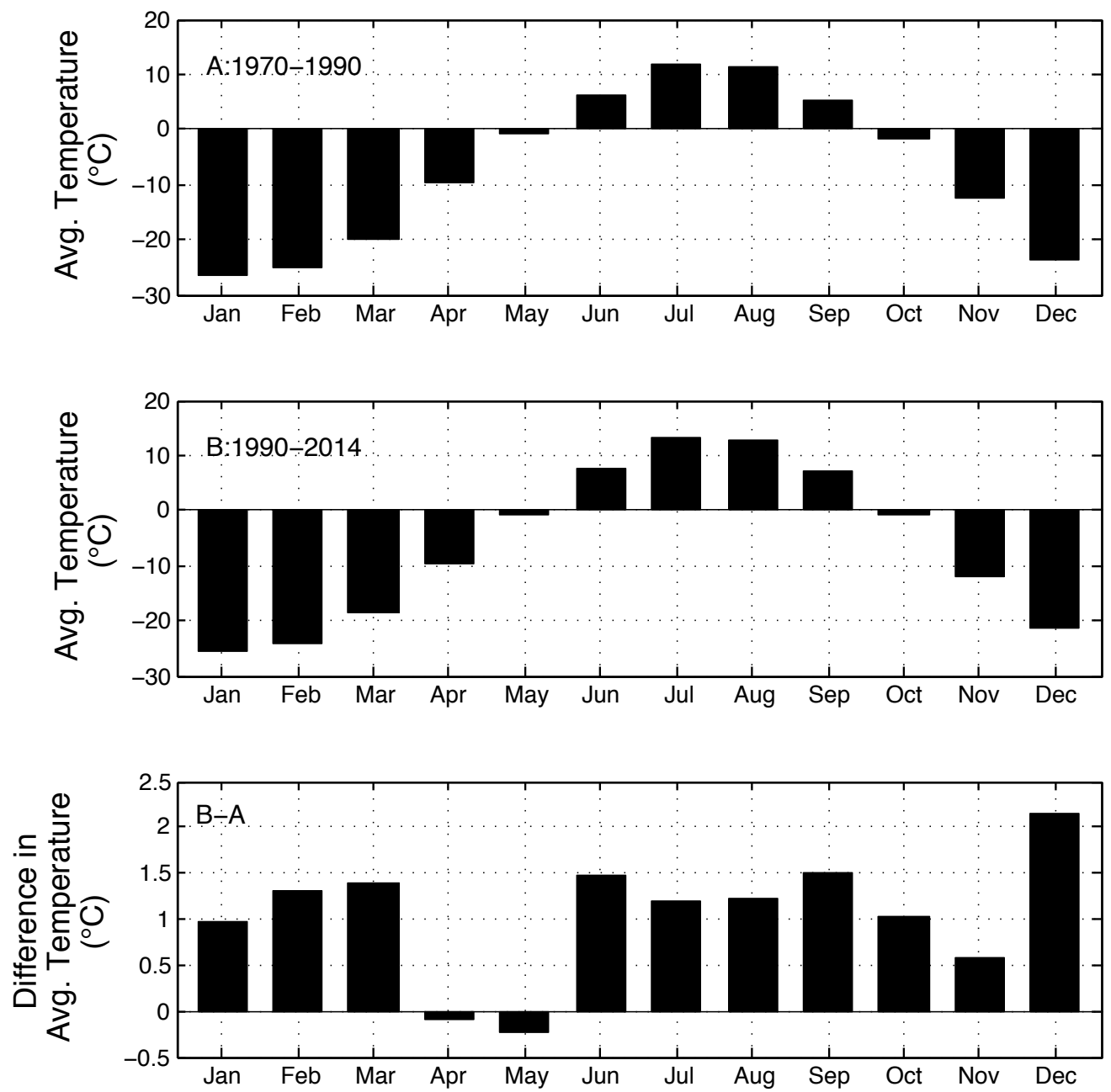

Figure 6.6: The average temperature for each month during 1970-1990 (top panel) and 1990-2014 (middle panel) and the difference between these averages (bottom panel). Data for weather station "Churchill A" obtained from Environment Canada (Environment Canada, 2014).

\subsubsection{Sea Ice: trends and variability, and the influence of fresh water on sea ice in Hudson Bay}

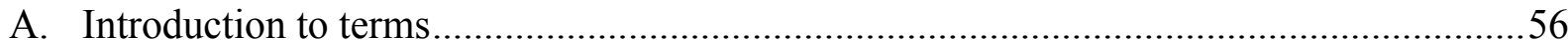

B. An introduction to sea ice in the Hudson Bay Complex.................................................57

C. Historical timing of sea ice freeze-up and melt .......................................................59

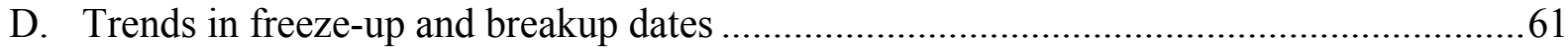

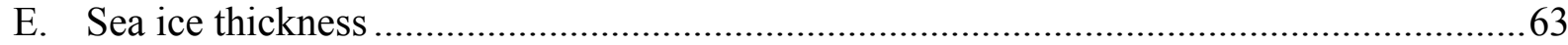

F. The influence of fresh water on sea ice in the Hudson Bay Complex .............................64

\section{A. Introduction of terms}

Sea ice is measured using many different parameters each with variable definitions. The parameters relevant to this assessment, and their meanings, are outlined below: 
First, it should be explained that ocean areas are typically divided into gridded squares for sea ice analysis (for example, squares of $5 \mathrm{~km}$ by $5 \mathrm{~km}$ ). The various sea ice measurements are then determined for each square. The measurements for each square can then be combined at various scales to produce a value for an ocean area as a whole.

- Sea ice concentration: refers to the proportion or percentage of a given ocean area that is covered by sea ice.

- Median value of sea ice concentration: A method used to describe sea ice concentration in an area. The median value of sea ice concentration for the gridded squares in each area is used to represent the sea ice concentration of the area as a whole.

- Sea Ice Extent: refers to the area of ocean covered with a given concentration of sea ice.

- Freeze-up Date: Refers to the date when a given area of ocean is covered to a specified degree by a specified sea ice concentration. For example, Hochheim and Barber (2014) define 'freeze-up' to have occurred when $50 \%$ of an area has a sea ice concentration greater than $60 \%$.

- Breakup Date: The reverse of freeze-up date. For example, Hochheim and Barber (2014) use the first date where less than $50 \%$ of the area has a sea ice concentration greater than $60 \%$.

- Open water season: the period between breakup and freeze-up dates.

\section{B. An introduction to sea ice in the Hudson Bay Complex}

Sea ice is a defining element of the Arctic environment. The timing, thickness, and extent of sea ice are extremely important to both the wild and human populations of the Hudson Bay Complex (Stewart and Lockhart, 2005). The entire Complex typically undergoes a complete freeze and thaw cycle every year and second year ice is found only on rare occasions (Gagnon and Gough, 2005).

Sea ice begins to form in the Hudson Bay Complex in October in response to dropping air and sea surface temperatures. Increases in fresh water concentration, changes in salinity, and wind forcing also influence the timing of ice formation. As soon as ice forms and persists, snow begins to accumulate on the sea ice (Stewart \& Lockhart, 2005). The entire Hudson Bay Complex is typically covered with first-year ice by mid-December.

Although the Hudson Bay Complex is typically completely frozen throughout the winter season, there are several areas with recurring polynyas and leads where open water may exist (Figure 6.7). These areas of open water often lead the spring ice break up, as the open sea water has a lower albedo than the surrounding sea ice and therefore absorbs more solar energy, resulting in warming of the surface water and melt of the nearby ice (Canadian Coast Guard, 2012). 


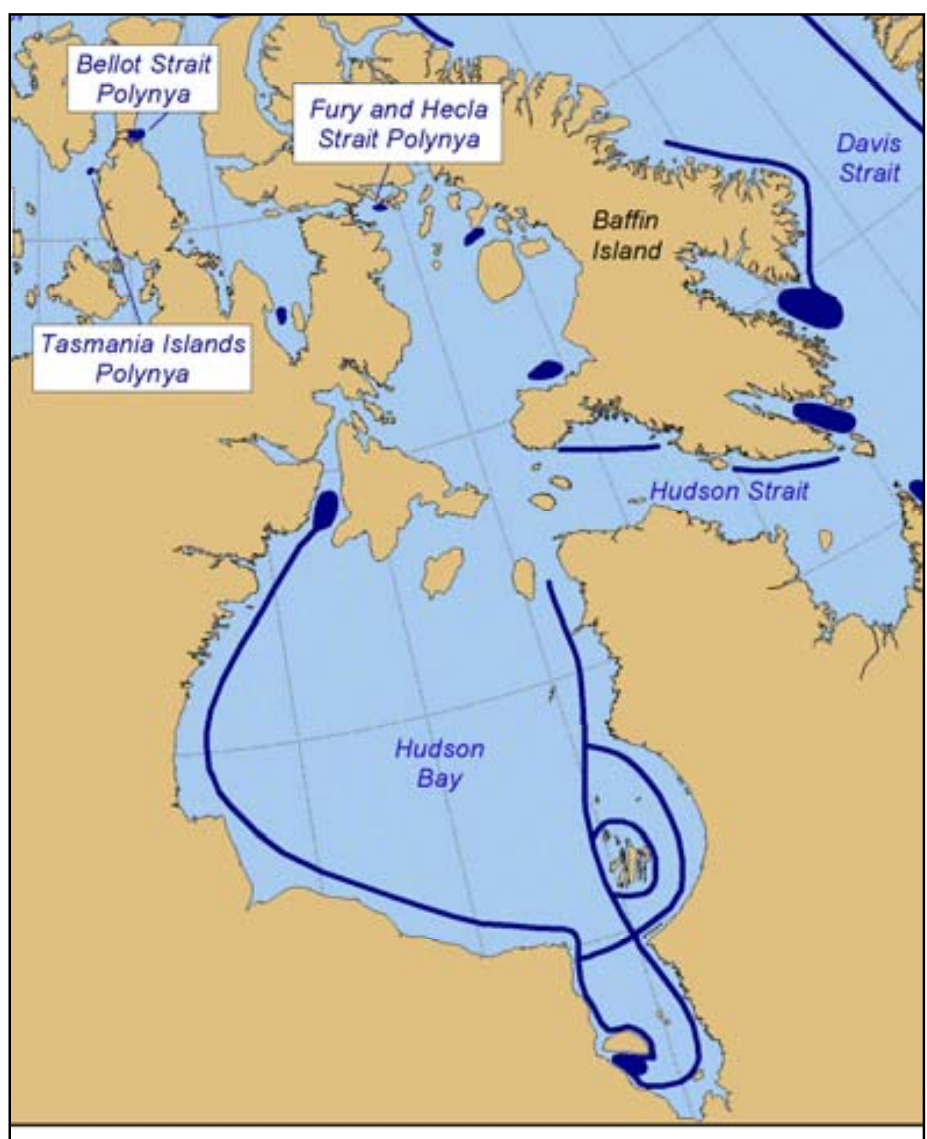

Figure 6.7: The locations of recurring polynyas and leads in the Hudson Bay Complex (indicated in dark blue on the map) (Canadian Coast Guard, 2012).

Hudson Bay and Hudson Strait are usually ice free by late-July or early August and Foxe Basin follows suite by mid-September (Hochheim and Barber, 2014). It should be mentioned that the freeze-up and breakup dates of all three areas of the Hudson Bay Complex exhibit high interannual variability, and sea ice timing in some regions can vary by as much as a month from year to year depending on local factors (Gagnon and Gough, 2005). 

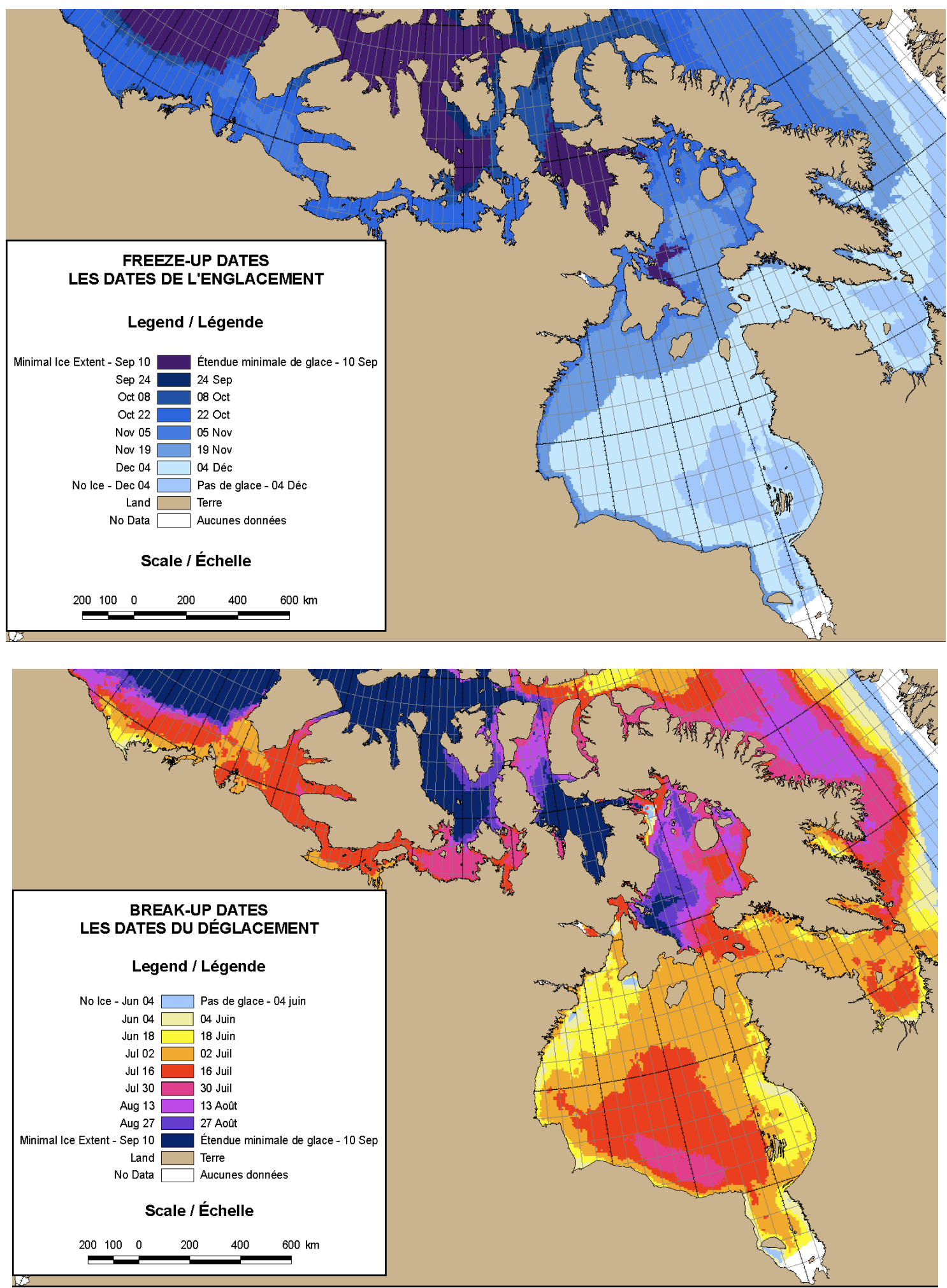

Figure 6.8: Average freeze-up and breakup dates between 1981 and 2010 in the Hudson Bay Complex. The different colours indicate where sea ice exists at the corresponding date. The edge of each colour indicates the location where the median value of ice concentration falls below 1/10 (Environment Canada, 2013d). 


\section{Historical timing of sea ice freeze and melt}

\section{Hudson Bay:}

Freeze-up: late October to early December.

Breakup: late May to early August.

Typically, sea ice forms in the north-western part of Hudson Bay in late October or early November and extends to the southeast of the Bay throughout late fall, leaving the Bay entirely ice-covered by December (Canadian Coast Guard, 2012). James Bay and eastern Hudson Bay are usually last to freeze up (Hochheim \& Barber, 2014). As freeze-up is taking place, "a 10 to 15 kilometre wide fringe of shore-fast ice develops along most of the coastline" of Hudson Bay (Canadian Coast Guard, 2012).

During the winter months, the sea ice is consolidated and consists of large floes (Hochheim, Barber, and Luckovich, 2010). Since 1990 the dynamic (wind) forcing of ice in Hudson Bay has been counter-clockwise, causing ice to circulate eastwards (Hochheim, Barber, and Luckovich, 2010).

Breakup typically begins in late May along the north-eastern and north-western coasts of the Bay, as well as in James Bay (Hochheim and Barber, 2014). The south-western regions of Hudson Bay are typically the last regions to be ice free due to wind and circulation patterns which drive drifting ice into the area (Gagnon and Gough, 2005). These final areas are usually ice free by early August (Hochheim and Barber, 2014).

\section{- Foxe Basin:}

Freeze-up: mid-October to mid-November.

Breakup: mid-June to mid-September.

Freeze-up typically begins in mid-October and is complete by mid-November. The melt season usually begins by mid-June with the area being ice free by mid-September. In the latter part of this melt season, ice from Hudson Strait can be transported westward into Foxe Basin. Nearly all ice in Foxe Basin is first year ice, however there is sometimes a very small remnant of secondyear ice at the beginning of freeze-up (Hochheim \& Barber, 2014).

\section{* Hudson Strait:}

Freeze-up: mid-November to early December.

Breakup: May to early July.

Freeze-up typically progresses from northwest to southeast and extends from mid-November to early December. However, ice within the channel remains unconsolidated throughout the winter due to winds and currents. The melt season usually extends from late May to early July (Hochheim \& Barber, 2014).

On average, Hudson Bay and Hudson Strait, which contain the Port of Churchill's international shipping route, are ice covered by December and ice free by August (Figure 6.9) (Tivy et al., 2011). However, this timing exhibits a high degree of inter-annual variability. For example, in 
some years delayed freeze-up can cause relatively ice-free conditions to persist into November, several weeks after the Port of Churchill shipping season has typically ended (Tivy et al., 2011).

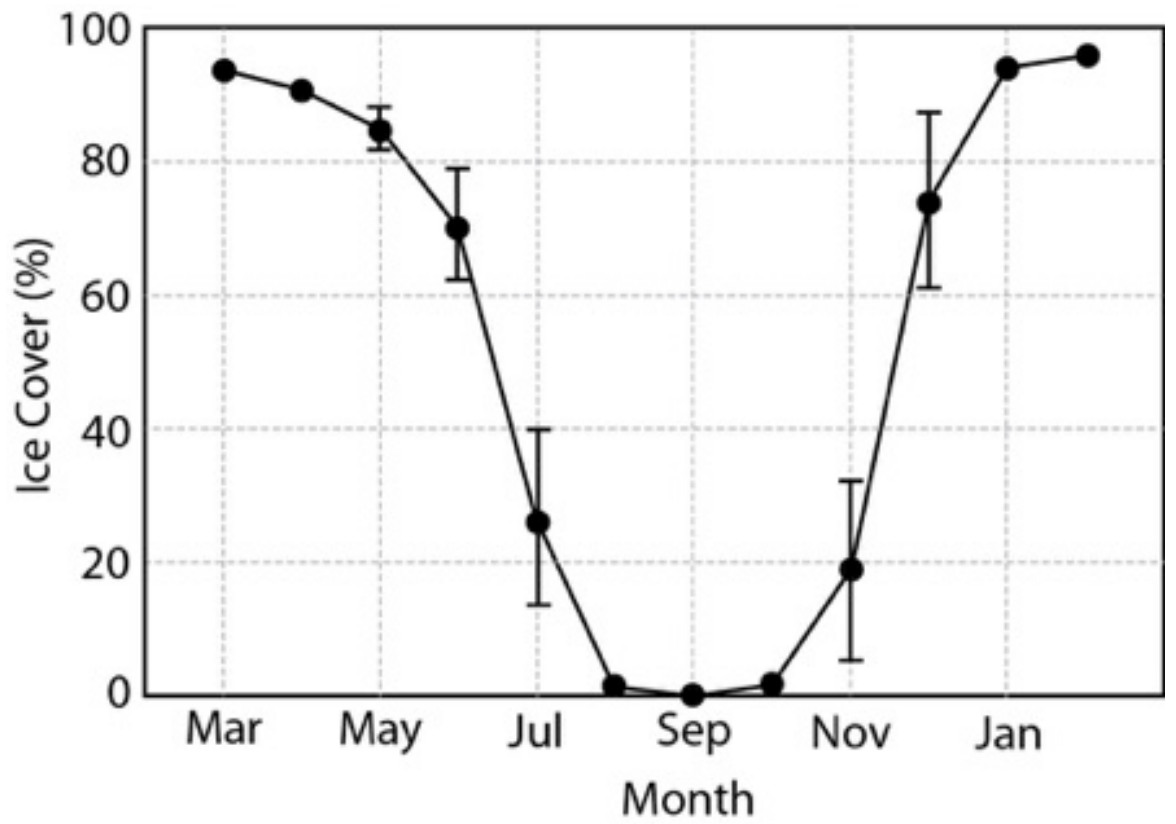

Figure 6.9: The monthly average ice cover in Hudson Bay and Hudson Strait from 1971-2007. The error bars indicate the variability in the ice cover of each month. Adapted from Tivy at al. (2011).

\section{Trends in freeze-up and breakup dates}

Figure 6.8 demonstrates the average freeze-up and breakup dates in the Hudson Bay Complex between 1981 and 2010. However, simply examining the average dates between 1981 and 2010 does not reveal any directional trend in sea ice timing over that time frame. In fact, the timing of freeze-up and breakup in the area changed significantly between 1981 and 2010:

Hochheim and Barber (2014) found statistically significant changes throughout the Hudson Bay Complex for sea ice extent, freeze-up dates, and breakup dates between 1980 and 2010 (Figure 6.10). These changes are not evenly distributed across the Hudson Bay Complex; instead, the changes reflect the Complex's variation in thermodynamic (temperature) and dynamic (wind) forcing, as well as freshwater cycling towards the SE corner of Hudson Bay (Hochheim \& Barber, 2014). Overall, ice trends are greatest in eastern Hudson Bay and Hudson Strait, with smaller trends in the centre and southwest of Hudson Bay and in James Bay; this is particularly true in spring.

The entire Hudson Bay Complex has experienced an increase in the length of the open water season (Figure 6.10). In a comparison of sea ice timing from 1996-2010 versus 1980-1995, the open water season increased by an average of roughly 3.1 weeks in Hudson Bay, 3.5 weeks in Foxe Basin, and 4.9 weeks in Hudson Strait (Hochheim \& Barber, 2014). Hochheim and Barber (2014) considered freeze-up to have occurred in an area when $50 \%$ of the area has a sea ice concentration of more than $60 \%$ and breakup to have occurred when less than $50 \%$ of an area has 
a sea ice concentration of more than $60 \%$ (note that this is not the same definition applied by Environment Canada in Figure 6.8).
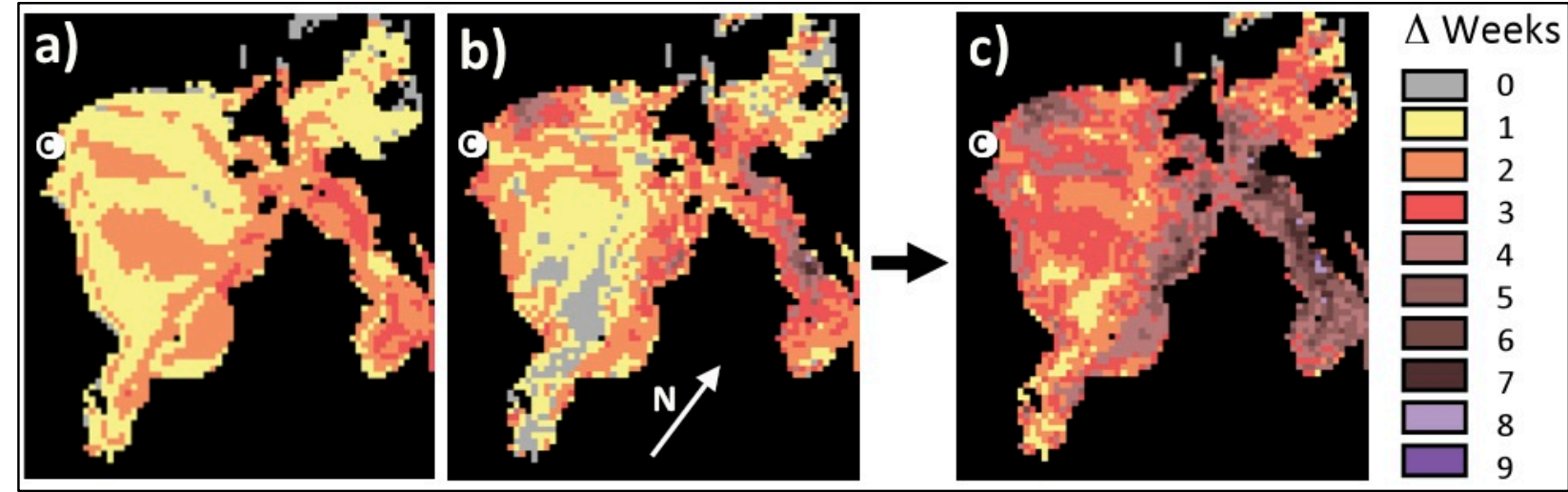

Figure 6.10: The spatial distribution of changes $(\Delta)$ in sea ice timing during (a) freeze-up and (b) breakup, and c) the total change in open water season length ( $\Delta$ freeze-up $+\Delta$ breakup) for 1996-2010 vs. 19801995. Changes, measured in weeks, were calculated as the difference in median freeze-up or breakup date between the two time periods. Churchill is indicated with the letter "c". Adapted from Hochheim and Barber (2014).

Hochheim and Barber (2014) also conducted some examination of the correlation between surface air temperatures surrounding the Hudson Bay Complex and sea ice extent and timing (recall that air temperatures are discussed in section 6.2.1). Some results are outlined in Table 6.2 below (Hochheim and Barber, 2014):

Table 6.2: Some results from an examination of sea ice extent (SIE) and surface air temperature (SAT) trends for the Hudson Bay Complex (Hochheim and Barber, 2014).

\begin{tabular}{|c|c|c|c|}
\hline & Hudson Bay & Foxe Basin & Hudson Strait \\
\hline $\begin{array}{l}\text { A. Mean change in open water } \\
\text { season length for } 1996-2010 \text { vs. } \\
1980-1995 \text { (weeks) }\end{array}$ & +3.1 & +3.5 & +4.9 \\
\hline $\begin{array}{l}\text { B. Mean change in freeze-up date } \\
\text { for 1996-2010 vs. 1980-1995 } \\
\text { (weeks later) }\end{array}$ & 1.6 & 2 & 2.4 \\
\hline $\begin{array}{l}\text { C. Mean change in late fall SIE for } \\
1980-1995 \text { vs. } 1996-2010^{*}\end{array}$ & $-30.5 \%$ & $-29.2 \%$ & $-46 \%$ \\
\hline $\begin{array}{l}\text { D. Change in fall SAT } \\
\text { corresponding to B. and C.** }\end{array}$ & $+1.5^{\circ} \mathrm{C}$ & $+1.9^{\circ} \mathrm{C}$ & $+2.9^{\circ} \mathrm{C}$ \\
\hline $\begin{array}{c}\text { E. Relationship between fall SAT } \\
\text { and freeze-up date }\end{array}$ & $\begin{array}{l}\text { Increase of } 1^{\circ} \mathrm{C} \text { delays } \\
\text { freeze-up by } 0.71 \text { weeks }\end{array}$ & $\begin{array}{l}\text { Increase of } 1^{\circ} \mathrm{C} \text { delays } \\
\text { freeze-up by } 0.88 \text { weeks }\end{array}$ & $\begin{array}{l}\text { Increase of } 1^{\circ} \mathrm{C} \text { delays } \\
\text { freeze-up by } 0.67 \text { weeks }\end{array}$ \\
\hline $\begin{array}{c}\text { F. Relationship between fall SAT } \\
\text { and late-fall SIE }\end{array}$ & $\begin{array}{l}\text { Increase of } 1^{\circ} \mathrm{C} \text { relates to } \\
14.4 \% \text { reduction in SIE }\end{array}$ & $\begin{array}{l}\text { Increase of } 1^{\circ} \mathrm{C} \text { relates to } \\
14.4 \% \text { reduction in SIE }\end{array}$ & $\begin{array}{c}\text { Increase of } 1^{\circ} \mathrm{C} \text { relates to } \\
15 \% \text { reduction in SIE }\end{array}$ \\
\hline $\begin{array}{l}\text { G. Mean change in breakup date } \\
\text { for 1996-2010 vs. 1980-1995 } \\
\text { (weeks earlier) }{ }^{* * *}\end{array}$ & 1.5 & 1.5 & 2.5 \\
\hline
\end{tabular}

*sea ice extent data from different weeks were used for the three locations: Hudson Bay - November $19^{\text {th }}$ to December $5^{\text {th }}$, Foxe Basin - October $29^{\text {th }}$ to November $18^{\text {th }}$, Hudson Strait - November $26^{\text {th }}$ to December $16^{\text {th }}$.

**Freeze-up dates and late-fall sea ice extent were correlated to seasonal temperatures from September to November (Sep-Oct-Nov) for Hudson Bay and Foxe Basin, and October to December (Oct-Nov-Dec) for Hudson Strait.

***Breakup dates were correlated with spring and fall surface air temperatures and wind strengths, thus a simple ice/temperature relationship could not be presented here. 
Hochheim and Barber (2014) found close relationships between fall surface air temperatures and both freeze-up dates and late fall sea ice extent. Moreover, the authors found correlations between spring ice conditions, fall and spring air temperatures, and spring winds; more explicitly, analysis indicated that variation in spring sea ice extent and breakup dates are linked with fall and spring surface air temperatures (70-80\%) and spring wind strengths (20-30\%) (Hochheim and Barber, 2014). These correlations suggest that more reliable forecasting for spring sea ice cover may be possible using statistical methods.

It should be mentioned that sea ice in Hudson Bay can be influenced by natural cyclical events. The North Atlantic Oscillation NAO and the El Niño Southern Oscillation (ENSO) are both known to influence sea ice dynamics. These natural cycles could be contributing to the observed changes in sea ice timing along with anthropogenic greenhouse gas emissions.

\section{E. Sea ice thickness}

Sea ice thickness in the Hudson Bay Complex has also been changing in recent decades, although the trends are not as clear as those related to freeze-up and breakup dates. Sea ice thickness is largely determined by atmospheric air temperatures and the depth of snow that accumulates on top of the ice. The insulating properties of the snow pack and the sea ice both act to reduce the influence of atmospheric temperatures once the ice has become established. In fact, snow depth is hypothesized to have a greater influence on sea ice thickness than atmospheric temperatures in the Hudson Bay Complex (Gough, Gagnon, and Lau, 2004). Deeper snow depths result in more insulation from the sub-zero atmospheric temperatures and produce thinner ice. The reverse is true for shallower snow depths (Gough, Gagnon, and Lau, 2004).

Sea ice thickness is also linked to the trends in freeze-up and breakup dates, because these dates determine the length of time that sea ice can grow as well as the length of time that snow can accumulate on the ice (Gagnon and Gough, 2006). The trends in freeze-up and breakup dates are mostly driven by changes in atmospheric temperatures and wind strength (Hochheim \& Barber, 2014). Altogether, this results in a complex and sometimes conflicting mix of influences on sea ice thickness and helps explain why recent thickness trends are not as clear as might be expected. Before trends in ice thickness are discussed it should be mentioned that there are few historical data available for sea ice thickness in the Complex. Measurements are only available for a small number of areas within the landfast ice along the coast.

The Canadian Ice Service recorded weekly ice thickness measurements at seven landfast ice locations along the coast of the Hudson Bay Complex, with the collection timeframes at the seven stations running for all or part of the 45 years between 1958 and 2003. Gagnon and Gough (2006) analyzed this dataset and found that maximum ice thickness averaged $175 \mathrm{~cm}$ in Hudson Bay and increased from south to north, due to the temperature gradient across Hudson Bay, and

west to east, due to the transport of ice to the eastern side of Hudson Bay under the prevailing westerly winds (Gagnon and Gough, 2006). Maximum ice thickness was typically reached in 
March in the southern part of the Hudson Bay Complex and later at higher latitudes, occurring in May in the northernmost areas (Gagnon and Gough, 2006).

Between 1958 and 2003, most stations showed a trend towards an earlier occurrence of maximum ice thickness and this trend was significant at three stations (Gagnon and Gough, 2006). Data from the seven locations indicate a significant trend towards thicker ice in western Hudson Bay and a non-significant trend towards thinner ice in the eastern Bay. The thickness trend in western Hudson Bay was accompanied by a trend towards lower snow depth but trends in snow depth did not correlate with all results. Autumn air temperatures were also linked to the sea ice thickness trends (Gagnon and Gough, 2006). It must be noted that the analysis of Gagnon and Gough (2006) was limited to landfast ice along the coast and there are very few observations of ice thickness in the mobile pack ice of Hudson Bay.

\section{F. The influence of fresh water on sea ice in Hudson Bay}

The concentration of fresh water is an important variable in Hudson Bay. Fresh water influences a range of oceanographic variables, including temperature, salinity, and density. While fresh water can have many impacts on the ocean environment, this discussion will focus on the influence of fresh water in Hudson Bay as it relates to sea ice formation and growth. Although the previous sections presented a relatively comprehensive discussion of sea ice climatology in the Complex, we believe that a conceptual discussion of the role of freshwater will be of use to Port of Churchill stakeholders. This is because the influence of fresh water on sea ice in Hudson Bay is currently an area of active research and a foundation in the current science may be of use as more information comes to light and the discussion of this topic heats up.

\section{* Hudson Bay's freshwater inputs and outputs}

The concentration of fresh water in Hudson Bay is more or less constant from year to year. In other words, the Bay's freshwater concentration is roughly at a steady state, meaning that the Bay's freshwater inputs and outputs are roughly in balance over a longer time scale (St-Laurent et al., 2011). On a shorter time scale, however, the volume of fresh water in the Bay exhibits significant seasonal variation (St-Laurent et al., 2011):

There are four fluxes with significant influence on the Bay's fresh water concentration. Of the

four, the loss of fresh water to sea ice formation (output) and the release of this water with melting (input) cause the greatest fluctuations in the Bay's freshwater concentration; however, these fluxes are relatively stable and are well balanced. In addition to these two fluxes, freshwater also enters the Bay from coastal rivers (input) and is exported through Hudson Strait into the Labrador Sea (output). These fluxes can be more variable and may lead to variations in the Bay's freshwater balance. Finally, the influences of precipitation and evaporation are relatively minor compared to the four fluxes described above (St-Laurent et al., 2011).

\section{River Input and Freshwater Circulation in Hudson Bay}

Because the uptake and release of freshwater by sea ice essentially cancel one another over the course of the year, Hudson Bay's long-term freshwater budget is largely governed by river input 
and export to the Labrador Sea. The Hudson Bay drainage basin covers more than one third of Canada and produces a very large influx of river water into the Bay every year. Estimates of the mean annual river discharge in recent years vary between roughly $635 \mathrm{~km}^{3}$ and $775 \mathrm{~km}^{3}(\mathrm{St}$ Laurent et al., 2011; Déry et al., 2011); about 46\% of this input enters in James Bay (Gough, Robinson, and Hosseinian, 2005). This addition of fresh water affects the formation and persistence of sea ice throughout the Bay (Déry et al., 2011).

River input into Hudson Bay is a product of climate and hydroelectric activity (Déry et al., 2011). The volume of freshwater capable of flowing into the Bay is ultimately determined by precipitation volumes in the catchment area, but flow volumes and timing of input into the Bay can be influenced by hydroelectric regulation (Déry et al., 2011). Many of the rivers running into Hudson Bay are used to generate electricity, including large rivers such as the Nelson and La Grande, for example, which make up a significant portion of the Bay's river input. The regulation of these large rivers is likely capable of significantly changing the dynamics (timing, volume, etc.) of freshwater input into Hudson Bay (Déry et al., 2011). As a result, the impact of fresh water on ice dynamics in river estuaries and the Bay as a whole is not only dependent on climate, but may also be influenced by hydroelectric regulation (Déry et al., 2011).

The Bay's total annual river input declined from 1964 to the mid 1980s and then displayed a rising trend until 2008 (Déry et al., 2011). During this period (1964-2008), there was a notable shift towards higher stream flow in winter relative to summer. This has resulted in a "flattening of the hydrograph", meaning that there is less variation in river flows throughout the year (Déry et al., 2011). It has been hypothesized that this shift is a product of hydroelectric regulation, as river water is now stored in reservoirs and then used to generate electricity during winter (Déry et al., 2011). The ice-related consequences of this altered stream flow for the waters of the Bay and its estuaries remain an area of active investigation.

At present volumes, the enormous input of fresh water into the Bay "represents the addition of a $80 \mathrm{~cm}$ layer of freshwater if distributed over the whole area of the basin" (St-Laurent et al., 2011). However, river water does not simply flow out and cover the entire Bay. Recent research by St-Laurent et al. (2011) sheds some light on the movement of river water through the Bay:

- River water enters the Bay as a freshwater plume and is then deflected to the right along the coast, following the counter-clockwise pattern of the currents within the Bay.

- Most of this river water continues along the coast but roughly $25 \%$ of the annual river water input is transported into the central Bay by seasonal cross-shore currents.

- The fresh water continues to cycle along the coast and exchange with the central Bay until some of the near coast fresh water is lost through Hudson Strait.

○ For example, roughly $35-50 \%$ of the river discharge from James Bay is recirculated into western Hudson Bay while the remainder is transported into the central Bay or Hudson Strait (Gough, Robinson, and Hosseinian, 2005). 
- The average residence time for river water in the Bay is 3 years, before exiting via the Strait.

During its time in the Bay, river water may have a significant effect on sea ice. For example, the relatively early breakup of sea ice in eastern Hudson Bay has been attributed to the large volume of fresh water flowing northward along the coast after the spring runoff in James Bay (Gagnon and Gough, 2005). The input of fresh river water may be locally important in initiating break-up in other areas of the Bay as well, as spring freshets tend to arrive when the Bay is still ice covered; this arrival of liquid water accelerates the melt and break-up processes (Ingram et al., 1996). It has also been suggested that fall sea ice extent in western Hudson Bay may be a function of river discharge volumes from James Bay, as fresh water from river outlets in James Bay reaches western Hudson Bay just before freeze-up and may provide a significant "preconditioning for ice formation" (Gough, Robinson, and Hosseinian, 2005). Significant correlations between sea ice extent and river input have been observed in other arctic seas, such as the Beaufort (Saucier \& Dionne, 1998).

A relatively simple model simulation by Gough (1998) highlights some potential ice-related effects of varying river runoffs into Hudson Bay: First, years with high runoff entering James Bay could increase ice thickness by up to $10 \mathrm{~cm}$ in the southeastern Bay and by $1 \mathrm{~cm}$ elsewhere. Second, one-year modifications in regulated runoff brought about by changes in dam control could result in significant changes in winter sea ice cover for multiple years. However, Gough (1998) indicated that these hypothetical river-born modifications to the sea ice in the Bay would be small relative to the inter-annual variability that naturally occurs in the ice cover.

\section{- Estuaries: in general}

River input has a significant influence on near-shore ice dynamics, particularly in estuaries (Kuzyk et al., 2008). There are several well observed effects of river input during the ice season which may be relevant to estuarine and coastal infrastructure or operations: First, the arrival of heavy spring flows when the Bay is ice covered can lead to violent under- and over-flooding of coastal ice (Kuzyk et al., 2008). Second, the increased winter flows occurring in some of the rivers used for electricity generation may have resulted in enhanced sea ice formation in some estuaries in Hudson Bay (Déry et al., 2011). Third, the formation of estuarine ice cover can influence hydrological processes, resulting in altered biological and sediment transport processes, and salt intrusion (Wang et al., 2012).

\section{* Estuaries: the Churchill River Estuary}

The Churchill River is a highly modified waterway. The river is not only dammed, but currently as much as $90 \%$ of the flow is diverted into the Nelson River for use in electricity generation (Kuzyk et al., 2008); this diversion began at the Missi Falls dam in 1977 and was increased in 1986 (Manitoba Water Stewardship Division, n.d.). The diversion substantially reduces river discharge at the Churchill River estuary. In 1998 Manitoba Hydro constructed a weir just south of the Churchill Estuary in an effort to replace habitat and recreational opportunities lost with the 1976 diversion (Manitoba Hydro, n.d.). As a result of the Churchill River's significant 
modification, flow volumes into Hudson Bay and past the Port of Churchill do not necessarily follow the same trends as unmodified rivers or other rivers altered for hydroelectric purposes. Therefore conclusions about the relationships between river input and sea ice or other estuarine processes generated from studies at other sites must be applied with caution to the Churchill estuary.

In a study of the Churchill River in 2005, Kuzyk et al. (2008) measured relatively low discharge in winter, rising rapidly in early spring and peaking in mid-May. Several further observations were made that could be relevant to the Port of Churchill: First, the estuary currently supports roughly one metre of ice growth. Second, sections of accumulated ice and landfast ice can be abruptly lost from the estuary during the winter-spring period. Third, during peak flows the river water flushes the estuary. Fourth, the estuary was largely clear of ice by the end of May (Kuzyk et al., 2008).

Kuzyk et al., (2008) examined the sea ice break-up processes in the Churchill River estuary. However, the timing of freeze-up in the estuary may be more relevant to the Port of Churchill's operations: With regards to breakup, the estuary is largely clear of ice by the end of May (Kuzyk et al., 2008), which is well before ice conditions in the Bay permit shipping (see Figure 6.9). But with freeze-up, ice formation in the estuary has sometimes delayed or halted the port's activities while conditions in the Bay remained suitable for shipping (J. McEachern, personal communication, February 18, 2015).

Unfortunately, recent trends in sea ice thickness, freeze-up, and breakup in the Churchill River estuary have not yet been examined, though this information would be valuable for the Port of Churchill. It is known that the river's diversion in 1977 significantly altered its discharge and it is possible that this in turn affected the ice regime in the estuary. Since the river's diversion in 1977, discharge volumes have continued to exhibit intra- and inter-annual variation in response to both climatological factors (e.g. precipitation) and upstream regulation of the Churchill River's flow. More investigation is required to understand how these variations in discharge influence ice in the estuary. A better understanding of the factors controlling freeze-up in the estuary could be especially valuable for the Port of Churchill.

\subsubsection{Sea Level}

Relative sea level, which is the height of the sea relative to a fixed point on land, is the relevant metric for discussing sea level in Hudson Bay and at the Port of Churchill (in this assessment the term "sea level" will always refer to relative sea level unless otherwise specified). Sea level is not constant but rather varies in response to a mixture of long- and short-term influences. At the Port of Churchill, sea level is influenced by long-term geological processes, shorter term variations in river discharge and wind patterns, and the tidal cycle (Gough \& Robinson, 2000). Important trends in sea level are discussed below. For reference, tidal sea level change in Churchill averaged roughly 3 metres (or $3000 \mathrm{~mm}$ ) between high and low tide for the time period 2005 to 2015 (data from Fisheries and Oceans Canada, 2015). 


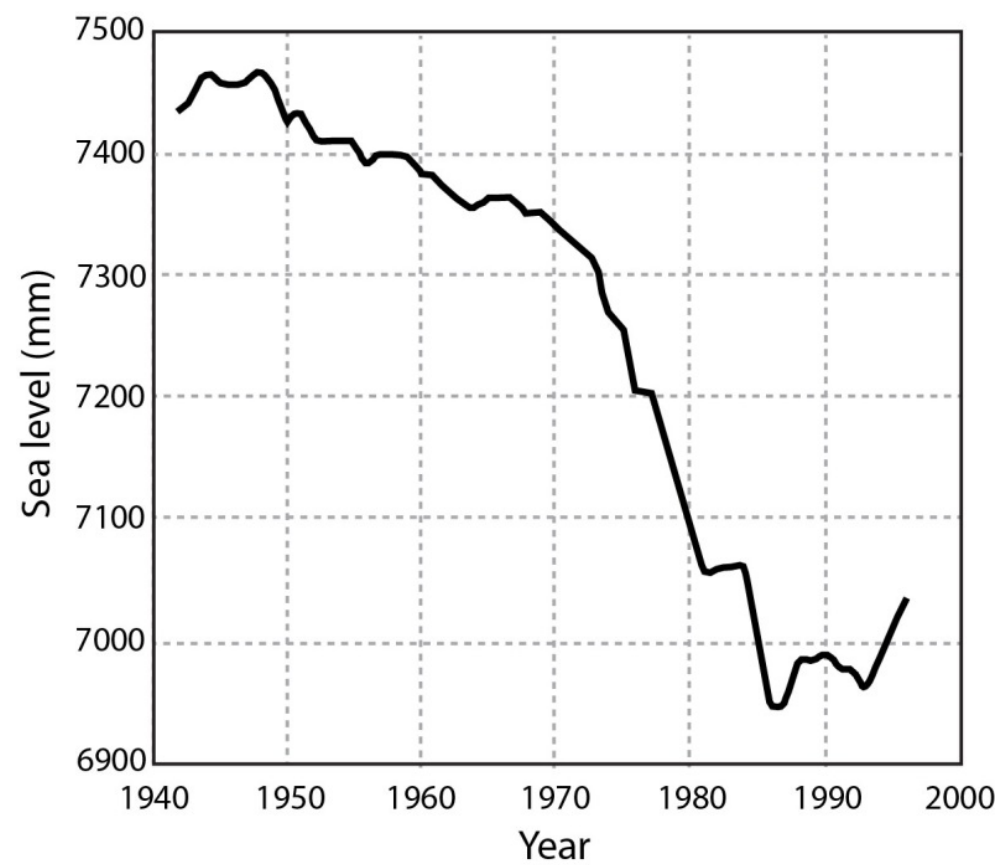

Figure 6.11: The five year running mean of sea level at Churchill Manitoba for 1940 to 1998. Adapted from Gough \& Robinson, 2000.

First, on a large time and geographic scale, sea level in Hudson Bay has been falling for the thousands of years since the last ice age (which peaked roughly 18000 years ago) as isostatic rebound causes the land to rise (Wolf et al., 2006). As a result of isostatic rebound, sea level in Churchill declined by roughly $550 \mathrm{~mm}$ between 1940 and 1985 (Gough and Robinson, 2000). However, since 1986 the sea level in Churchill has more-or-less levelled off (Figure 6.11), and it has been suggested that the sea level rise caused by climate change is largely offsetting the sea level decline caused by isostatic rebound (Gough and Robinson, 2000). These observations agree with the suggestion from Gough (1998) that sea level may cease to fall in Hudson Bay in the near future. Gough (1998) further hypothesized that sea level in Hudson Bay could begin to rise within the next 100 years as a result of continued climate change-induced sea level rise. However, this is difficult to predict as it is dependent on a combination of complex environmental factors and variable human factors.

\section{* Seasonal sea level variation}

Sea level also varies roughly $300-350 \mathrm{~mm}$ (or $30-35 \mathrm{~cm}$ ) on a seasonal time scale near the Port of Churchill. This variation is thought be a product of river discharge from the Churchill, the Nelson, and the rivers flowing in to James Bay (Gough and Robinson, 2000). The sea level in Churchill typically reaches its lowest point in April and then increases during May and June with the arrival of the spring freshets from the Churchill River and the nearby Nelson River (Gough, Robinson, and Hosseinian, 2005). After the spring freshets, sea level remains relatively stable during the summer until September, when sea level rises again (Figure 6.12). Gough, Robinson, and Hosseinian (2005) attribute this second rise to the delayed arrival of water from the spring 
river discharge into James Bay. Sea level peaks in Churchill during October and declines through winter until the April minimum (Gough, Robinson, and Hosseinian, 2005). Lower sea levels have been observed near the Port in late winter and the magnitude of seasonal variation in sea level has increased by roughly 50mm since the diversion of the Churchill River began in 1976 (Gough \& Robinson, 2000).

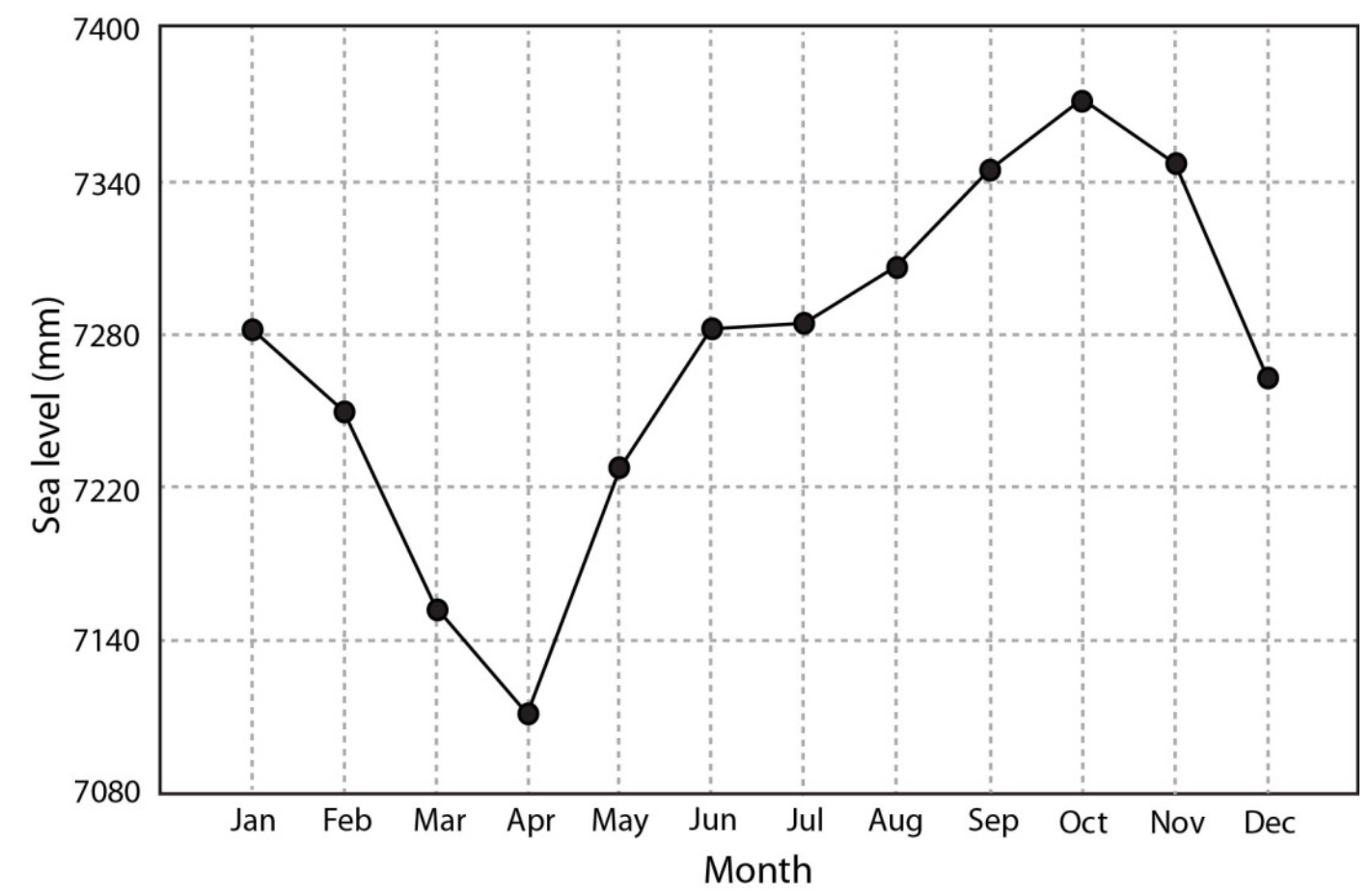

Figure 6.12: Mean intra-annual variation of sea level at Churchill, MB, from 1963 to 1983. Adapted from Gough, Robinson and Hosseinian, 2005.

In summary, it is hypothesized that the seasonal variation in sea level at the Port of Churchill is significantly influenced by discharge from the nearby Churchill and Nelson Rivers as well as the more distant rivers flowing in to James Bay (Gough, Robinson, and Hosseinian, 2005). These rivers display natural variability in the timing and volume of their discharge, but are also displaying earlier spring runoff and changes in annual runoff volumes in response to climate change. Furthermore, many of these rivers are used for hydroelectric generation and their flow volumes may be subject to seasonal variation according to hydroelectric requirements (Déry et al., 2011). Changes in discharge volumes from the Churchill, the Nelson, and from rivers in James Bay caused by climate factors and hydroelectric activity may have the ability to influence the local sea level at the Port of Churchill (Gough, Robinson, \& Hosseinian, 2005). The suggested scale of this influence is unclear. 


\subsubsection{Adverse Weather: Trends}

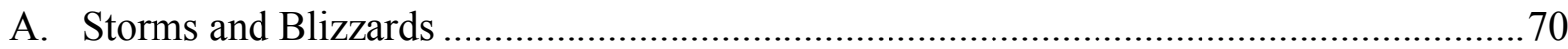

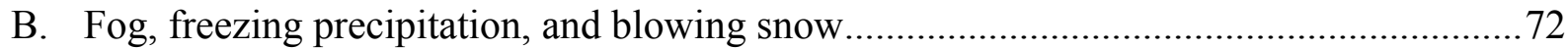

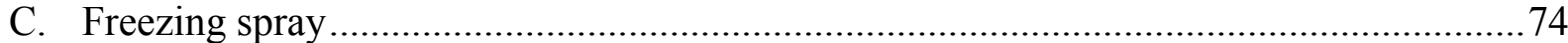

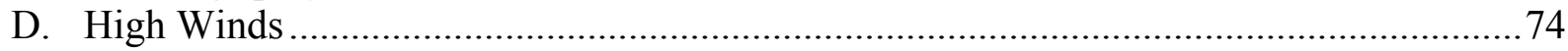

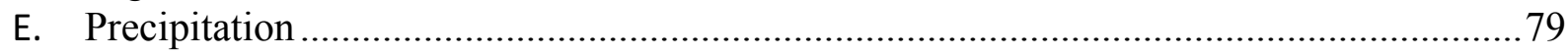

Following Hanesiak and Wang (2005) who analyzed trends in "adverse weather", we define "adverse weather" as storms and blizzards, fog, freezing precipitation, blowing snow, freezing spray, high winds, and precipitation. At present, there is very little published research discussing the frequency of adverse weather in the Hudson Bay Complex. In fact, there appears to be little research of this nature available for any part of the Canadian Arctic. However, some studies were found and are referenced in this section. Moreover, Arctic meteorology is currently an area of active research and much more information will likely be available in the coming years.

\section{A. Storms and blizzards}

Many studies of arctic weather comment on the likelihood of increasing storminess in the future and scientists appear quite confident in predicting a rise in arctic storm frequency in recent history and into the future (e.g. Hanesiak et al., 2010). However, few studies provide quantitative descriptions of this increasing trend in the Hudson Bay Complex.

In an examination of cyclone frequency throughout the Arctic basin north of $68^{\circ} \mathrm{N}$ (which is 10 degrees north of Churchill), Sepp and Jaagus (2011) found that cyclonic activity increased significantly between 1948 and 2002. This increase reflected changes in the number of cyclones entering the arctic basin and the number of cyclones beginning within this region (Sepp \& Jaagus, 2011). (Note that for the purposes of this assessment, the terms "cyclone" and "storm" can be used more or less interchangeably). In addition to a projected rise in storminess in the Arctic, Vermaire et al., (2013) also expect increased susceptibility to storm surges in low lying areas of the arctic, particularly when climate-induced changes in sea ice are considered.

\section{* Storms in the Hudson Bay Complex}

The storm regime in the Hudson Bay Complex is influenced by both large- and regional-scale atmospheric processes. Large-scale processes include the behaviour and location of the polar front, while important regional-scale processes include sea ice extent and the temperature gradients between ocean, land, and atmosphere (Savard et al., 2014). With respect to these regional-scale influences on the storm regime, Savard et al. (2014) identify three distinct periods, or "seasons", in the Hudson Bay Complex:

- Period 1, January to mid-May: Ice cover is complete, there is no thermal contrast between the sea surface and the neighbouring continental surface.

- Period 2, May to early September: These months include the melting (May-July) and early open water time periods (July-early September). During this time the temperature of the ocean in the Hudson Bay Complex is colder than the temperature of the nearby landmasses, 
resulting in a thermal gradient between land and sea. The ocean acts as a heat sink for the atmosphere.

- Period 3, September to December: The thermal gradient between the ocean and the landmasses reverses and strengthens, and the ocean waters of the Hudson Bay Complex become a heat source for the atmosphere. The flux of heat and humidity from the ocean waters to the atmosphere strengthens such that it favours the formation, intensification, and regeneration of atmospheric depressions in the region.

With respect to-larger scale processes, the summer and fall are most prone to storms. This is because the frontal zone between the cold Arctic air and the warmer temperate air moves north towards northern Hudson Bay in the summer; this frontal zone supports the formation of atmospheric depressions and storms (Savard et al., 2014).

Storm activity in the Hudson Bay Complex is thus greatest during the months of August to December, because both the regional- and larger-scale atmospheric conditions are at their most favourable for supporting atmospheric depressions (Savard et al., 2014). On the regional scale, the flux of heat and humidity from ocean to atmosphere creates and strengthens atmospheric depressions and causes a slowing of the movement of these depressions, resulting in longer residence times in the Bay for these weather systems (Savard et al., 2014). On a larger scale, the frontal zone is in its northern position over Hudson Bay. As a result, the August to December time period is sometimes referred to as the "storm season", and this so-called storm season peaks in October and November (Savard et al., 2014).

A more quantitative description of the Hudson Bay Complex's storm regime was provided in a 2011 non-peer-reviewed workshop presentation lead by Environment Canada meteorologist Phillipe Gachon (Gachon et al., 2011). Using three different reanalysis data sets running from 1979 to either 2004 or 2009, Gachon et al., (2011) were able to present the monthly frequencies for several characteristics of storm tracks in the Hudson Bay area:

- Storm frequency: There is little intra-annual variability in storm frequency within the Hudson Bay Complex. Generally, storms occur most often during spring and fall, when the thermal contrast is greatest between the land and sea, and occur less often during winter and summer, when the thermal gradient is weaker. Storm frequency is greatest from August to December and peaks in October (this agrees with the results of Savard et al., 2014).

- Fall months (Sept-Oct-Nov) average 2.5 storms per month or slightly more, while winter or early summer months (e.g. February or July) average closer to 2 storms per month.

- Storm Intensity: Intense storms are most frequent in fall and spring and are relatively infrequent in summer.

○ There is roughly 1 intense storm per month in October, November, and March; other fall and spring months are just below 1. The frequency of intense storms is also relatively high in winter (just under one per month) but is very low in summer (roughly 0.2 per month). 
- Average storm intensity is highest in fall, although all months are quite similar.

- Average storm length is between 3 and 4 days for all months, though storms average slightly longer from late spring through to early fall. These results agree with the observation by Savard et al., (2014) that storm tracks are slowed during the "storm season".

Gachon et al., (2011) did not comment on any historical trends in the storm tracks over the Hudson Bay Complex.

\section{Blizzards in the Hudson Bay Complex}

In an examination of hazardous weather in the Canadian Arctic, Ricketts and Hudson (2001) of the Meteorological Service of Canada reported the average number of blizzard events per year for several locations within the Hudson Bay Complex (shown below). The authors defined blizzards as "visibility of $1 \mathrm{~km}$ or less in blowing snow and/or snow, winds of $40 \mathrm{~km} \mathrm{~h}^{-1}$ or more and temperature below freezing; conditions lasting for at least 6 hours" (Ricketts \& Hudson, 2001). The annual frequency data for blizzards reported by Ricketts and Hudson (2001) are shown below:

- Churchill: 5.5

- Rankin Inlet (western Hudson Bay): 16.9

- Coral Harbour (northern Hudson Bay): 11.7

- Cape Dorset (western Hudson Strait): 3.5

- Hall Beach (northern Foxe Basin): 10.4

The values shown above are the average values per year between 1980-1999, with the exception of Rankin Inlet (1982-1999) and Cape Dorset (1985-1999). The authors did not comment on trends in blizzard frequency within the time frame examined (Ricketts \& Hudson, 2001).

\section{B. Fog, freezing precipitation, and blowing snow}

Hanesiak and Wang (2005) examined trends in the frequency of "adverse weather" (including fog, freezing precipitation, blowing snow, and low cloud ceiling) using data collected at 15 weather stations across the Canadian Arctic between 1953 and 2004. This analysis included three weather stations in the Hudson Bay Complex: Hall Beach in northern Foxe Basin, Coral Harbour in northern Hudson Bay, and Churchill. The average monthly frequencies of fog, low ceiling, and freezing precipitation between the mid-1950s and 2004 for these three locations are presented in Figure 6.13 (Hanesiak \& Wang, 2005).

Hanesiak and Wang (2005) also examined the longer-term trends in these adverse weather conditions between the mid 1950s and 2004. The results are outlined below:

\section{* Freezing Precipitation:}

- When considering all 15 climate stations, the Canadian Arctic experienced a significant increase in the incidence of freezing precipitation between the 1950s and 2004. However, this broad approach belies the regional variation:

○ Churchill did not experience any significant change in freezing precipitation. 
- Coral Harbour and Hall Beach did not experience a significant change in freezing precipitation when all months are considered together, but freezing precipitation in both locations increased significantly in spring and fall, and declined significantly in winter.

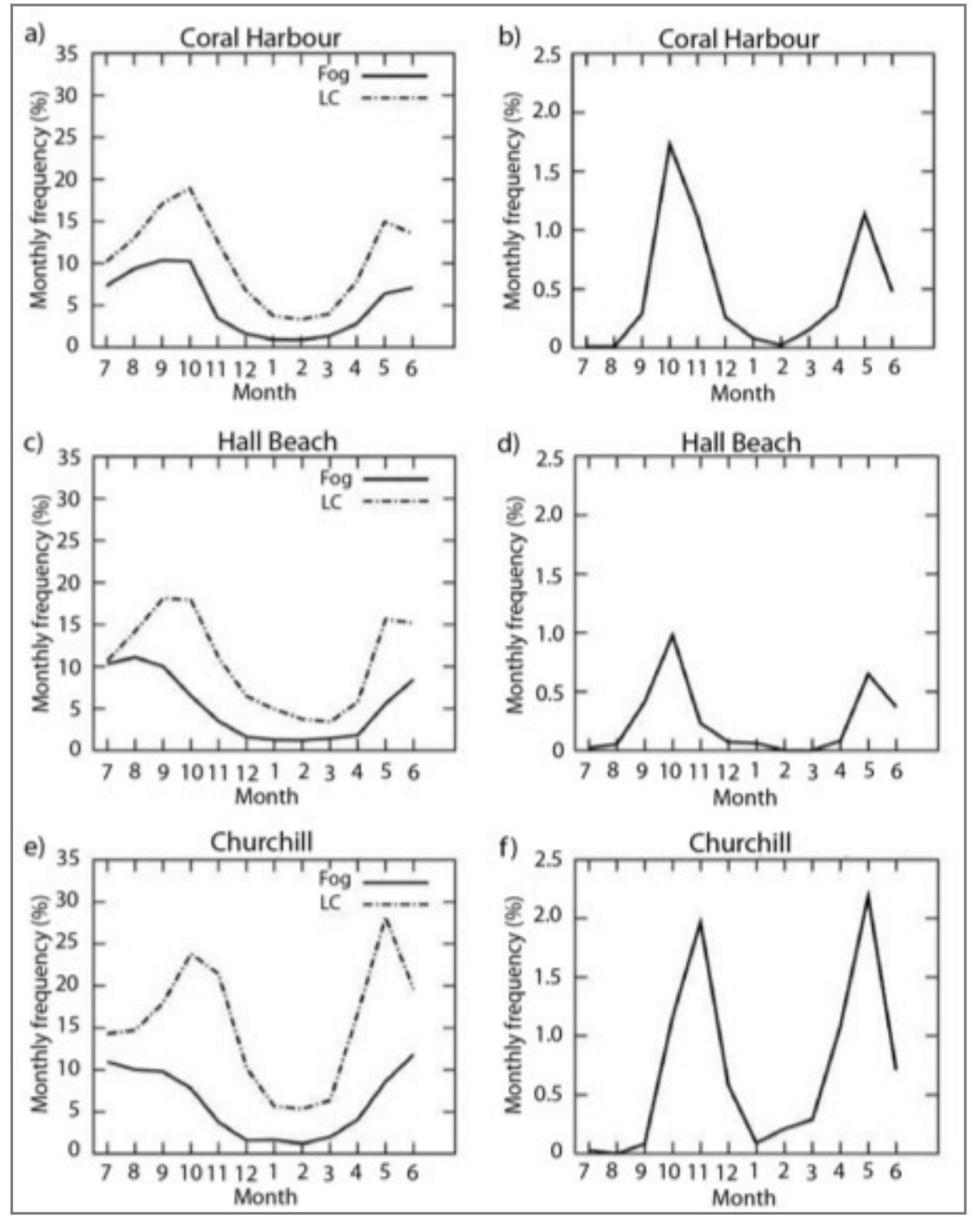

Figure 6.13: The average monthly frequency (\% of days) with fog and low ceiling (left column), or freezing precipitation (right column) in Coral Harbour, Hall Beach, and Churchill. Analysis extends from 1955 to 2004 for Coral Harbour and from 1953 to 2004 for Hall Beach and Churchill. Adapted from Hanesiak \& Wang, 2005.

\section{Fog:}

Fog events were counted when fog cover "extends to at least $2 \mathrm{~m}$ above ground level and reduces visibility to less than 5/8 mile (ie. $1 \mathrm{~km}$...)" (Hanesiak \& Wang, 2005).

- The frequency of fog events appears to have increased at the western Arctic stations and decreased at the eastern stations during the time frame examined. 
- There was no significant change in the frequency of fog events at any of the three Hudson Bay Complex stations with the exception of a significant decline in fog frequency at Churchill in the fall.

\section{- Blowing Snow:}

Defined as "snow particles raised by the wind to sufficient heights above the ground to reduce the horizontal visibility at eye level $(1.8 \mathrm{~m})$ to 6 miles or less." (Hanesiak \& Wang, 2005).

- The trend in blowing snow is primarily negative when all 15 stations are considered.

- Churchill, Coral Harbour, and Hall Beach all experienced a significant decline in blowing snow events when all 12 months are considered, but no significant change in any one season.

\section{Freezing spray}

Fog, freezing precipitation, rain, and wet snow can all cause ice to form on vessels operating in Arctic waters. This superstructure icing can be quite hazardous to shipping. The most common cause of superstructure icing in the Hudson Bay Complex is freezing spray, which occurs when air temperatures fall below the freezing temperatures of sea water and sea surface temperatures are below $6^{\circ} \mathrm{C}$ (Canadian Coast Guard, 2012). Ice accretion rates from freezing spray can exceed 2 centimetres per hour and can lead to ice buildup of $25 \mathrm{~cm}$ or more. Spray icing is most frequently encountered in October and November in the Hudson Bay Complex, due to the combination of cold air temperatures and remnant warm surface waters from the summer (Canadian Coast Guard, 2012). No research discussing trends in the frequency of freezing spray in the Hudson Bay Complex could be found to inform this analysis.

\section{High winds}

Very little information exists in the scientific literature about wind speed within the Hudson Bay Complex, especially on the frequency of high wind speeds that can hamper shipping operations. Using the results from the analysis of both Reanalysis data and in situ observations from Environment Canada weather stations located throughout the Complex, we examined the historical wind conditions within the Complex. This examination was focused on the months of the shipping season (July to November).

* Wind speeds in the Hudson Bay Complex

Generally, monthly mean wind speeds over Hudson Bay vary from 15 to $23 \mathrm{~km} \mathrm{~h}^{-1}$, peaking during late fall and early winter after a summer minimum (Figure 6.14; Gachon et al., 2011). 


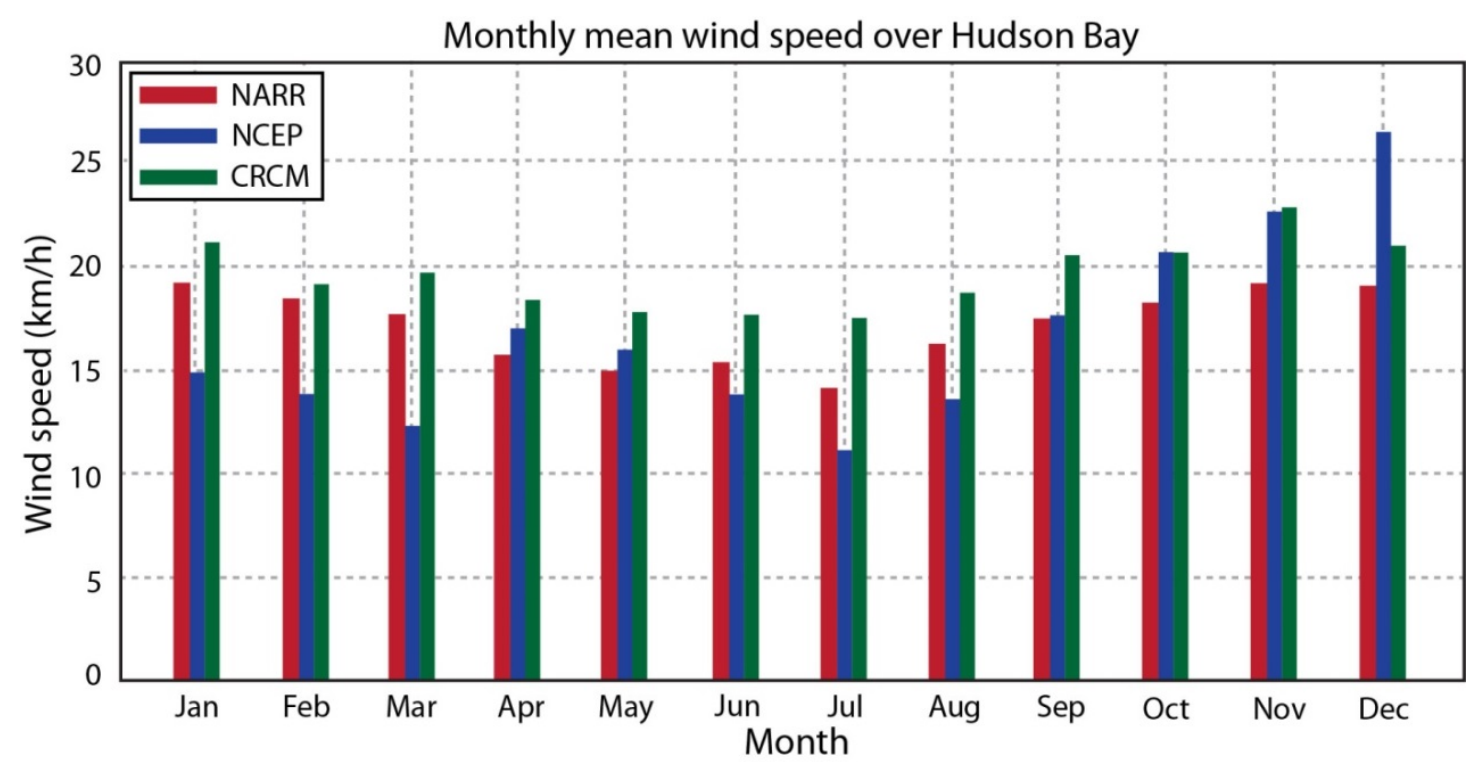

Figure 6.14: Montly average windspeeds $\left(\mathrm{km} \mathrm{h}^{-1}\right)$ for the Hudson Bay area provided by three reanalysis datasets running from 1979 to 2004 or 2009. Adapted from Gachon et al., 2011.

Focusing on the shipping season through the Hudson Bay Complex (July to November) we analyzed wind speed observations from seven Environment Canada weather stations located throughout the Complex (Figure 6.15).

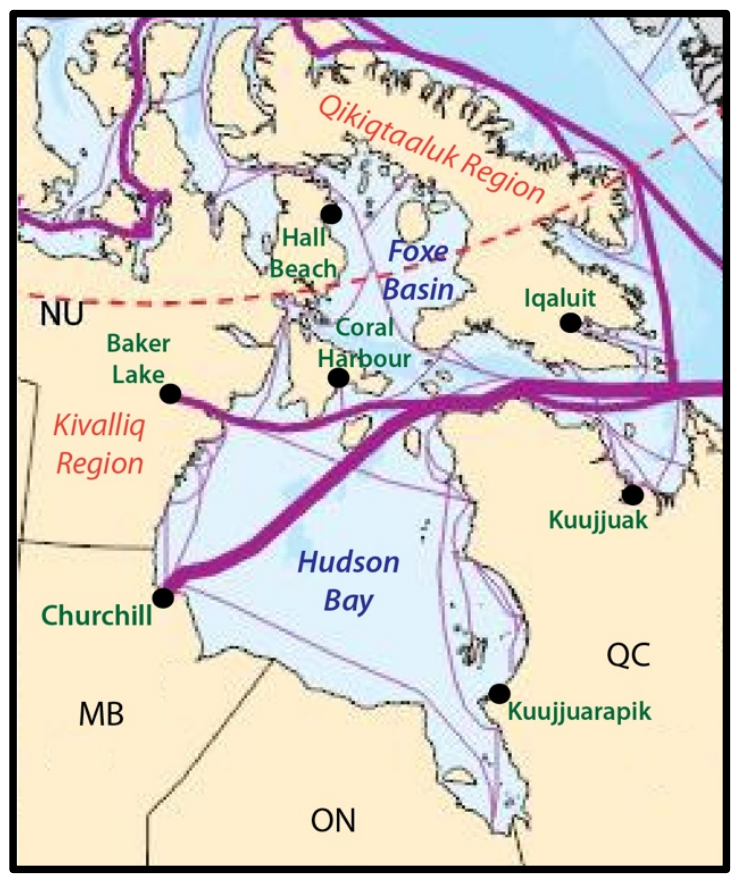

Figure 6.15: The location of the Environment Canada weather stations (show in green) that recorded data used in the analysis of wind trends shown below (adapted from DFOs Arctic voyage planning guide).

Monthly means (or averages), calculated from 2001 to 2011, show that wind speeds peak towards the end of the shipping season, during September, October, and November (Table 6.3). Monthly mean wind speeds during the shipping season are greatest in Iqaluit and Churchill, and 
lowest in Kuujjuarapik and Coral Harbour (Table 6.3). Analyzing the 41 year (1970-2011) wind speed record at each station reveals only three instances of significant positive trends in monthly mean wind speed during the shipping season: Hall Beach during July $\left(0.860 \mathrm{~km} \mathrm{~h}^{-1} \mathrm{decade}^{-1}\right)$ and November $\left(1.175 \mathrm{~km} \mathrm{~h}^{-1}\right.$ decade $\left.^{-1}\right)$ and Baker Lake during August $\left(0.690 \mathrm{~km} \mathrm{~h}^{-1}\right.$ decade $\left.^{-1}\right)$. Annual mean wind speeds (2001-2011) are greatest in Churchill and Hall Beach, both of which have also experienced significant positive trends in annual mean wind speeds since 1970 of 0.290 and $0.592 \mathrm{~km} \mathrm{~h}^{-1}$ decade $^{-1}$, respectively. No significant trends indicating decreasing wind speeds were observed.

Table 6.3: Average monthly and annual wind speeds $\left(\mathrm{km} \mathrm{h}^{-1}\right)$ between 2001 and 2011. (+) indicate locations and time frames with significant positive trends between 1970 and 2011. Significance was determined using $p<0.05$ at the $95 \%$ confidence level. Data from Environment Canada (2013b).

\begin{tabular}{|l|c|c|c|c|c|c|}
\hline & July & August & September & October & November & Annual \\
\hline Baker Lake & 13.6 & $15.9(+)$ & 17.5 & 19.3 & 20.5 & 18.1 \\
\hline Churchill & 17.8 & 19.3 & 21.3 & 24.0 & 22.7 & $21.2(+)$ \\
\hline Coral Harbour & 14.6 & 16.2 & 15.4 & 16.7 & 18.5 & 17.2 \\
\hline Hall Beach & $14.7(+)$ & 15.5 & 16.6 & 18.6 & $20.1(+)$ & $21.0(+)$ \\
\hline Iqaluit & 17.3 & 19.1 & 22.1 & 23.6 & 26.1 & 17.0 \\
\hline Kuujjuaq & 13.8 & 13.5 & 16.6 & 18.4 & 20.5 & 13.4 \\
\hline Kuujjuarapik & 11.9 & 11.1 & 14.0 & 13.6 & 14.8 & 17.5 \\
\hline
\end{tabular}

\section{- Wind speeds in Churchill}

Winds speeds are relatively high in Churchill compared to other locations in the Hudson Bay Complex (Table 6.3). Monthly mean wind speeds in Churchill peak during October (Table 6.3). There was a significant positive trend of $0.290 \mathrm{~km} \mathrm{~h}^{-1}$ per decade in the average wind speed during the shipping season (July-November) between 1970 and 2011 (Figure 6.16; data from Environment Canada (2013b). Seasonally, wind speeds are lowest during summer and greatest during fall and winter. Spring wind speed increased significantly at a rate of $0.506 \mathrm{~km} \mathrm{~h}^{-1}$ decade $^{-}$ ${ }^{1}$ between 1970 and 2011 (Figure 6.16).

While monthly, seasonal, and annual mean wind speeds and their associated trends provide useful context for understanding wind at the Port of Churchill, their application to transportation is limited. The Port's operations and marine transportation are not vulnerable to monthly average winds but rather to strong winds occurring on an hourly or daily timeframe. Thus, we determined the frequency with which hourly winds exceeded different speed thresholds during the shipping season (July to November) between 1991 and 2011 (Table 6.4). Within this analysis we estimate based on the Beaufort Wind Force Scale that, in general, wind speeds greater than $30 \mathrm{~km} \mathrm{~h}^{-1}$ could disrupt or slow the loading of grain, while wind speeds greater than $50 \mathrm{~km} \mathrm{~h}^{-1}$ could make docking and tugboat related operations dangerous and thereby delay or halt Port operations. The following analysis was completed using weather station data ordered from Environment Canada. 


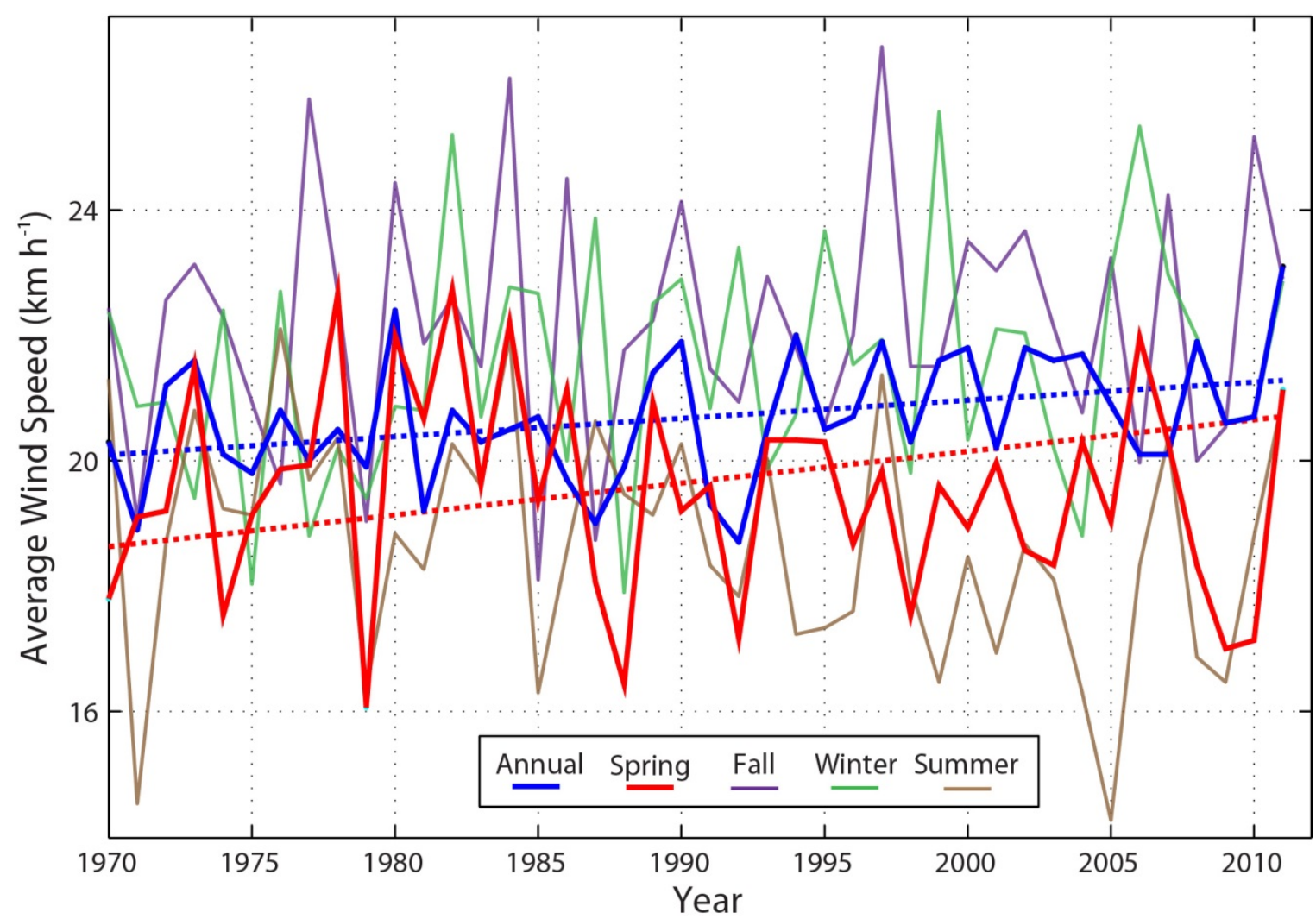

Figure 6.16: Trends in seasonal and annual wind speeds $\left(\mathrm{km} \mathrm{h}^{-1}\right)$ in Churchill from 1970 to 2011. Dashed trend lines are statistically significant and indicate an annual trend of $0.290 \mathrm{~km} \mathrm{~h}^{-1}$ decade $^{-1}$ (blue) and a spring trend of $0.506 \mathrm{~km} \mathrm{~h}^{-1}$ decade $^{-1}$ (red). Significance was determined using $p<0.05$ at the $95 \%$ confidence level. Data from Environment Canada (2013b).

Table 6.4: The average number of days per month or shipping season with an hourly wind speed measurement greater than or equal to each wind threshold, between 1991 and 2011. Results produced by analysis of weather station data from Environment Canada.

\begin{tabular}{|c|c|c|c|c|c|c|c|}
\hline $\begin{array}{c}\text { Threshold } \\
\left(\mathbf{k m ~ h}^{-1} \mathbf{)}\right.\end{array}$ & July & August & September & October & November & December & $\begin{array}{c}\text { Shipping Season } \\
\text { (July -November })\end{array}$ \\
\hline$\geq 10$ & 30.9 & 31.0 & 30.0 & 31.0 & 29.9 & 30.4 & 152.7 \\
\hline$\geq 20$ & 26.8 & 26.8 & 27.9 & 27.6 & 27.1 & 25.9 & 136.0 \\
\hline$\geq 30$ & 13.0 & 15.2 & 19.8 & 20.2 & 19.4 & 17.0 & 87.7 \\
\hline$\geq 40$ & 3.0 & 4.9 & 9.4 & 10.2 & 9.2 & 8.0 & 36.6 \\
\hline$\geq 50$ & 0.9 & 1.8 & 4.0 & 4.5 & 3.8 & 3.4 & 14.9 \\
\hline$\geq 60$ & 0.1 & 0.4 & 1.1 & 1.7 & 0.9 & 0.8 & 4.2 \\
\hline
\end{tabular}

On average, hourly wind speeds exceeded $30 \mathrm{~km} \mathrm{~h}^{-1}$ on 88 days of the 153-day long shipping season $(\sim 57 \%)$ and exceeded $50 \mathrm{~km} \mathrm{~h}^{-1}$ on 14.9 days $(\sim 10 \%)$ (Table 6.4$)$. Wind speeds exceeded each threshold above $30 \mathrm{~km} \mathrm{~h}^{-1}$ more often during October than during any other month of the shipping season, making October the most likely to experience delays as a result of high winds. Conversely, wind speeds exceed each threshold above $30 \mathrm{~km} \mathrm{~h}^{-1}$ the least often during July and 
August (Table 6.4), making them, in terms of wind speed, optimal months for Port operations. Generally, wind-delay of port operations is more likely to occur in the later months of the shipping season due to the higher winds of September, October, and November.

Between 1970 and 2011 there was a significant positive trend of 3.6 days per decade in the number of days during the shipping season with wind speeds that exceeded $30 \mathrm{~km} \mathrm{~h}^{-1}$ in Churchill (Figure 6.17). Over the 41 year time period, this is equal to an increase of 14.8 in the number of days where Port operations may be temporarily delayed by high wind speeds. There was no observed trend in the number of days during which winds exceeded $50 \mathrm{~km} \mathrm{~h}^{-1}$.

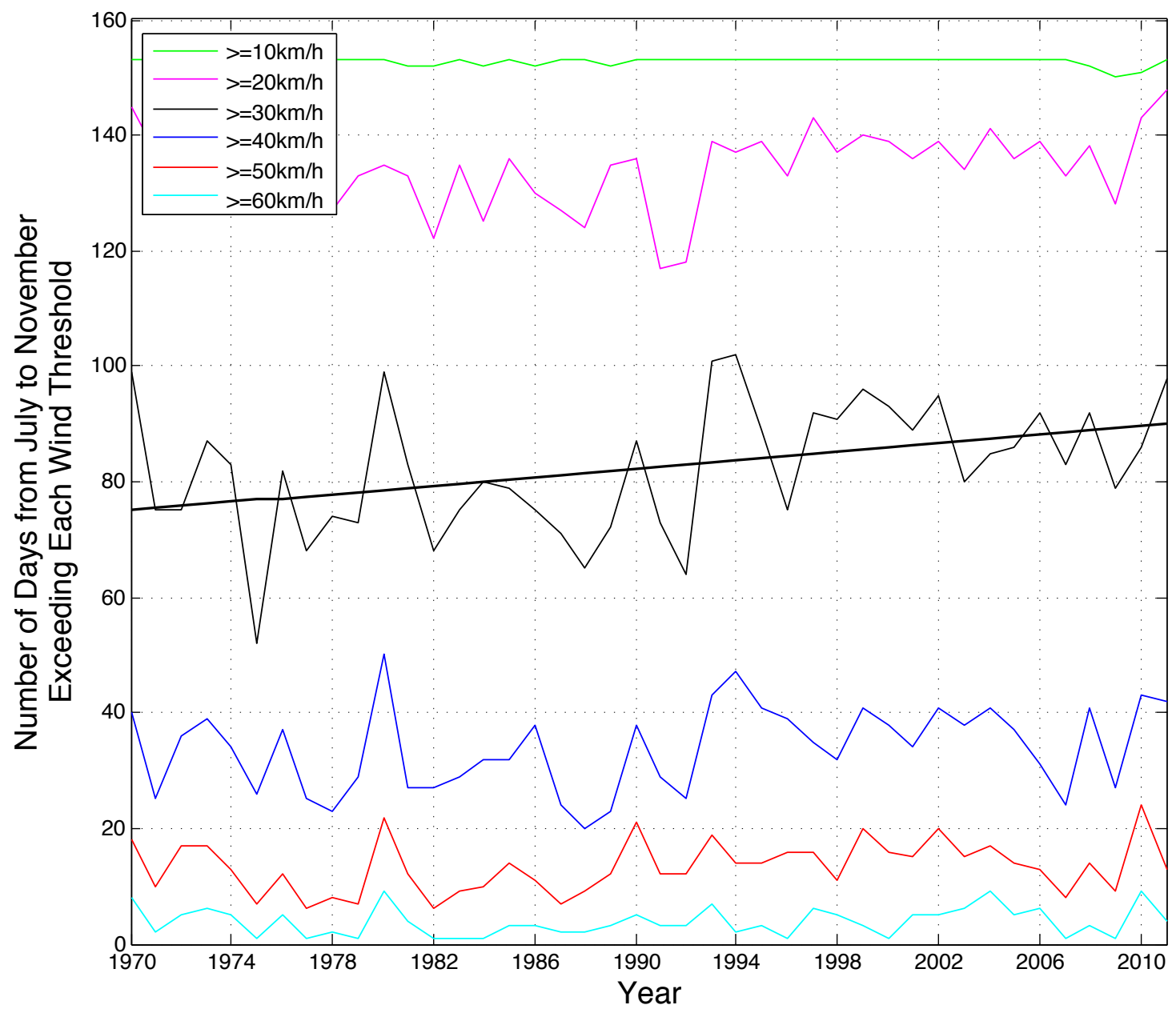

Figure 6.17: The number of days per shipping season (July to November (153 days total)) with a wind speed measurement greater than or equal to a given threshold between 1970 and 2011. The solid trend line indicates a significant trend. Significance was determined using $p<0.05$ at the $95 \%$ confidence level.

Results produced by analysis of weather station data from Environment Canada.

Comparing the frequency of days during which winds exceeded each threshold during the shipping season between the periods from 1970-1990 and 1991-2011 reveals a strong tendency towards greater wind speeds and increased potential for wind related delays in port operations (Table 6.5). The greatest increase for each threshold occurred during September, while the greatest increase for each month occurred at the $30 \mathrm{~km} \mathrm{~h}^{-1}$ threshold. The increase at the $30 \mathrm{~km}$ 
$\mathrm{h}^{-1}$ threshold corresponds to an added 10.4 days with potential wind-delays in port operations during the shipping season for 1991-2011 vs. 1970-1990 (again, this assumes that wind speeds greater than $30 \mathrm{~km} \mathrm{~h}^{-1}$ could disrupt or slow the loading of grain). The number of days during which winds exceeded $50 \mathrm{~km} \mathrm{~h}^{-1}$ increased by 3 days between the two periods, with over half of this change coming during September.

Table 6.5: The difference between the 1991-2011 and the 1970-1990 averages for the number of days per month or shipping season with an hourly wind speed greater than each wind speed threshold (i.e. 1991 to

2011 minus 1970 to 1990). Results produced by analysis of weather station data from Environment Canada.

\begin{tabular}{|r|c|c|c|c|c|c|c|}
\hline $\begin{array}{r}\text { Threshold } \\
\left(\mathbf{k m ~ h}^{-1}\right)\end{array}$ & July & August & September & October & November & December & $\begin{array}{c}\text { Shipping Season } \\
\text { (July - November })\end{array}$ \\
\hline$\geq 10$ & -0.1 & 0.0 & 0.1 & 0.0 & 0.1 & 0.0 & 0.0 \\
\hline$\geq 20$ & 0.5 & -0.1 & 1.7 & 0.2 & 1.1 & 1.1 & 3.3 \\
\hline$\geq 30$ & 2.5 & 2.2 & 3.5 & 1.0 & 1.1 & 2.2 & 10.4 \\
\hline$\geq 40$ & 0.6 & 1.0 & 3.1 & 0.3 & 0.5 & 1.0 & 5.5 \\
\hline$\geq 50$ & 0.4 & 0.6 & 1.6 & 0.3 & 0.1 & 1.2 & 3.0 \\
\hline$\geq 60$ & 0.0 & 0.3 & 0.5 & 0.3 & -0.3 & 0.2 & 0.9 \\
\hline
\end{tabular}

\section{E. Precipitation}

Precipitation most commonly represents "adverse" weather to the Port of Churchill's shipping operations when it occurs as grain is being loaded at the dock. This is because grain shippers prefer to keep grain dry at all times in order to maintain product quality. Our analysis of precipitation included only Churchill and not the entire Hudson Bay Complex, and only the months of the shipping season.

Historically between 50 and $80 \mathrm{~mm}$ of precipitation falls in Churchill during each month of the shipping season (Figure 6.18; data from Environment Canada (2013c)). Between 1970 and 2011 there were no significant trends in average monthly rain, snow, or total precipitation, except for a significant trend towards less snow in September $\left(-0.36 \mathrm{~mm} \mathrm{yr}^{-1}\right)$. However when comparing the periods from 1970-1990 and 1991-2011, we find a tendency towards increased total precipitation during the early shipping season and little change in the total precipitation during the later shipping season (Figure 6.18).

On average between 1991 and 2014, 51\% of the days in the shipping season had $0 \mathrm{~mm}$ of precipitation and were therefore ideal for grain loading (Table 6.6; results produced by analysis of weather station data ordered from Environment Canada). Comparatively, roughly one third of the days during the shipping season had more than $1 \mathrm{~mm}$ of precipitation and only $11 \%$ had more than $5 \mathrm{~mm}$ (Table 6.6). Due to missing data these values represent the 'percentage of days with measurements per month' rather than simply 'days per month'. 

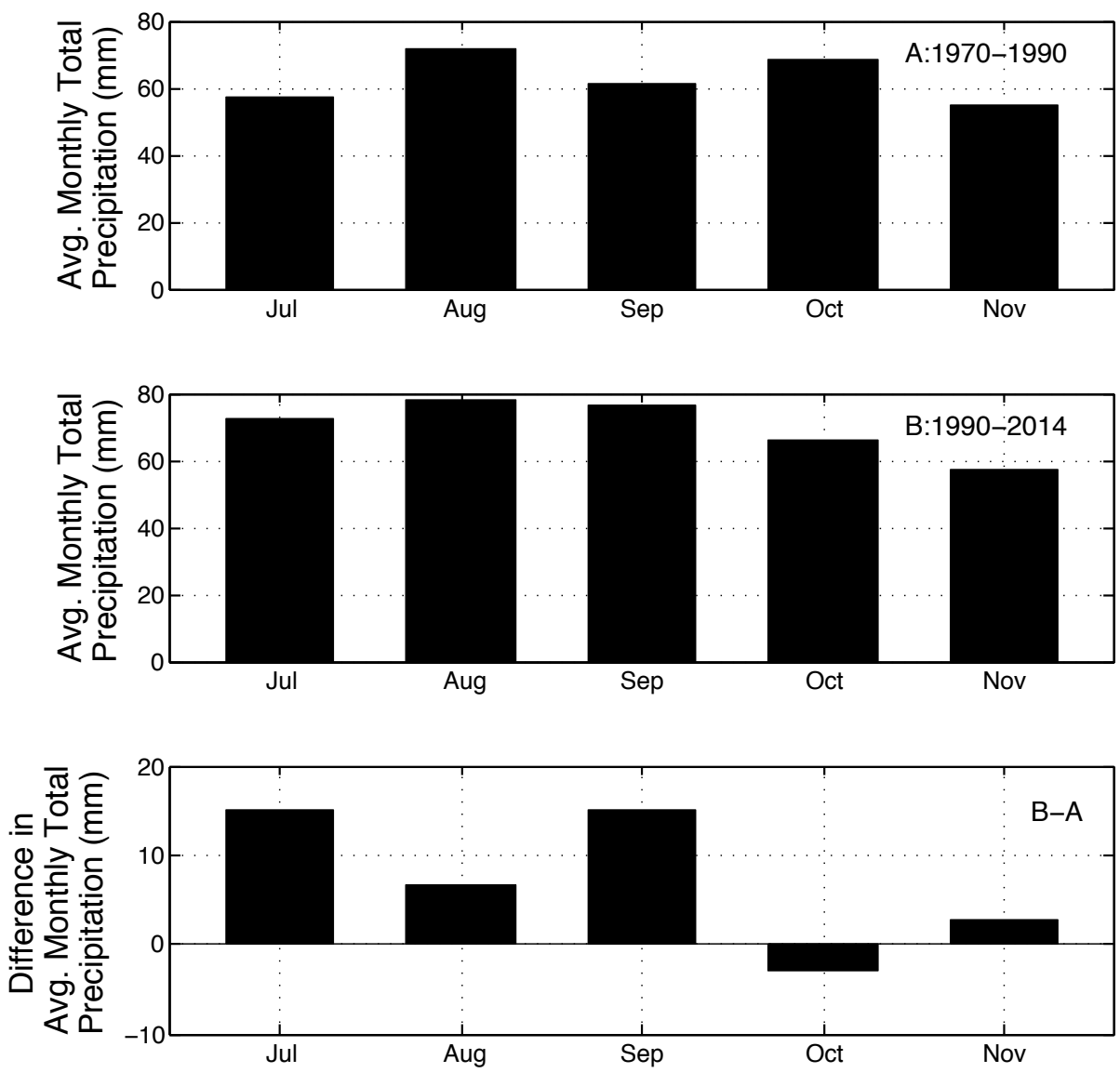

Figure 6.18: The average total precipitation for each month during 1970-1990 (top panel) and 1990-2014 (middle panel) and the difference between these averages (bottom panel). Only the months of the shipping season are presented. Data from Environment Canada (2013c).

Table 6.6: The monthly and seasonal average percentage of days with total precipitation greater than or equal to each threshold, between 1991 and 2014. Results produced by analysis of weather station data from Environment Canada.

\begin{tabular}{|c|c|c|c|c|c|c|}
\hline $\begin{array}{c}\text { Threshold } \\
(\mathbf{m m})\end{array}$ & July & August & September & October & November & $\begin{array}{c}\text { Shipping Season } \\
\text { (July - November) }\end{array}$ \\
\hline$=0$ & $53 \%$ & $49 \%$ & $47 \%$ & $51 \%$ & $56 \%$ & $51 \%$ \\
\hline$\geq 0.5$ & $39 \%$ & $44 \%$ & $46 \%$ & $40 \%$ & $35 \%$ & $41 \%$ \\
\hline$\geq 1$ & $29 \%$ & $34 \%$ & $35 \%$ & $31 \%$ & $24 \%$ & $31 \%$ \\
\hline$\geq 5$ & $14 \%$ & $15 \%$ & $15 \%$ & $9 \%$ & $5 \%$ & $11 \%$ \\
\hline$\geq 10$ & $8 \%$ & $8 \%$ & $7 \%$ & $4 \%$ & $1 \%$ & $6 \%$ \\
\hline$\geq 20$ & $2 \%$ & $2 \%$ & $3 \%$ & $1 \%$ & $0 \%$ & $2 \%$ \\
\hline
\end{tabular}

Total precipitation measurements should be used with caution for comparing precipitation quantities above $0 \mathrm{~mm}$ across inter- and intra-annual scales (ie. between and within years). This is because the measurements include both rain (more dense) and snow (less dense) and thus variation in total precipitation measurements could reflect a change in the amount of both snow 
and rain or a change in the precipitation ratio of rain to snow. This issue is not relevant when comparing or examining trends in the percentage of days with no precipitation.

Between 1970 and 2014 there are several significant trends in the percentage of days during which total precipitation reached a given threshold. Days with 0 precipitation decreased at a rate of $-2.8 \%$ ( 0.87 days) decade ${ }^{-1}$ during July while days in July with $>10 \mathrm{~mm}$ precipitation increased at $1.3 \%$ (0.40 days) decade ${ }^{-1}$. Days during August with greater than $10 \mathrm{~mm}$ of precipitation increased at $1.0 \%(0.31)$ decade $^{-1}$, while November days with 0 precipitation increased at $4.5 \%$ (1.35 days) decade ${ }^{-1}$.

In addition to the significant trends described above, we find a general tendency between 19701990 and 1991-2014 towards fewer days without precipitation in the early shipping season (July to September) and more days without precipitation during the latter part of the shipping season (October and November) (Figure 6.19). We also find an increase in the percentage of days during the early shipping season where total precipitation exceeded 1 and $5 \mathrm{~mm}$, and the opposite in the late shipping season. Overall between 1970-1990 and 1991-2014 total precipitation rose for the early months of the shipping season and declined for the later months of the shipping season.

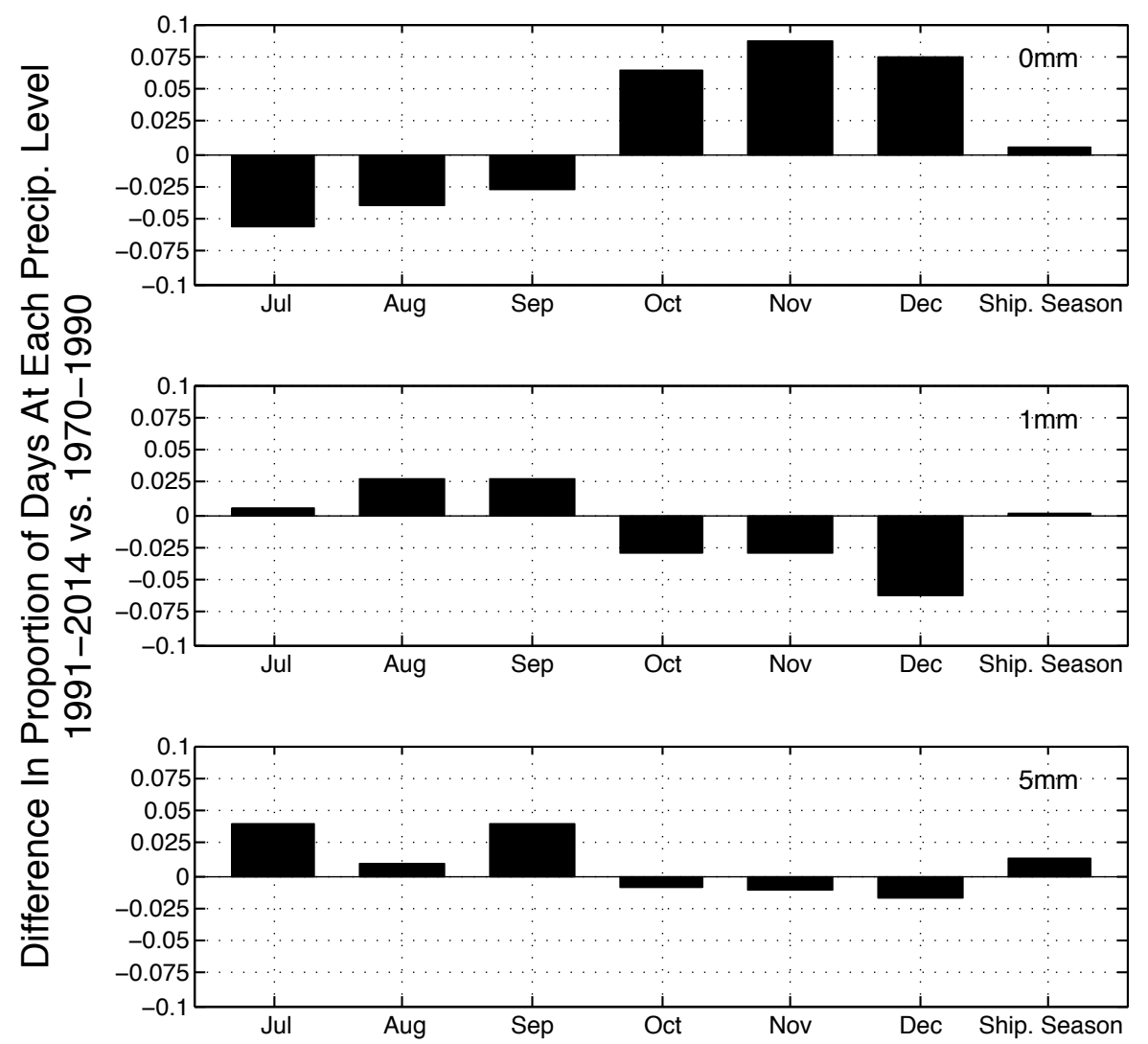

Figure 6.19: The difference in the 1991-2014 and 1970-1990 average proportions of days per month or per shipping season with total precipitation greater than or equal to $0 \mathrm{~mm}$ (top), $1 \mathrm{~mm}$ (middle), or $5 \mathrm{~mm}$ (bottom) (i.e. 1991-2014 minus 1970-1990). Positive values indicate the 1991-2014 value was greater, and vice versa. Results produced by analysis of weather station data from Environment Canada. 


\subsection{Projections}

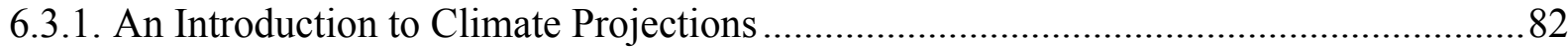

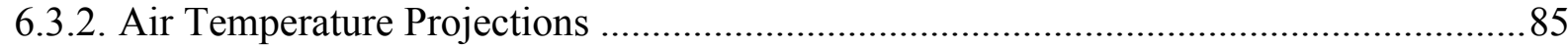

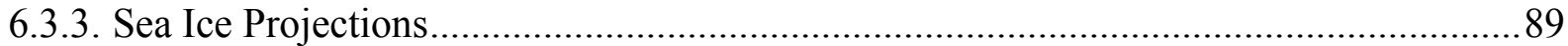

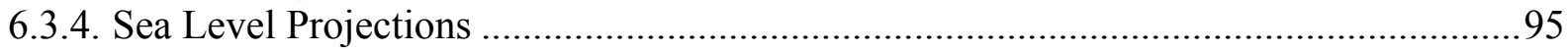

6.3.5. Adverse Weather Projections ……………………....................................................95

\subsubsection{An Introduction to Climate Projections}

Wherever possible, the climate projections discussed in this assessment extend to two points in the future: 2030 and 2050. In other words, this discussion is focusing on attempts to forecast environmental conditions 15 and 35 years from the present. It is important to remember that climate projections are estimates and are all subject to uncertainty and error. Moreover, all projections are liable to be changed and updated as time and science progress. While projections are useful for gaining some idea of future conditions, they must not be thought of as accurate predictions or guarantees.

The projections presented in this assessment were created using two methods: extrapolation and modeling. Many of the climate trends presented in section 6.2 were extrapolated to provide some estimate of future conditions if current trends were to persist. Some results of climate models, produced by CEOS researchers or obtained from the scientific literature, are also presented.

\section{* A brief introduction to climate projections using models}

Climate projections often rely on highly complex mathematical models. These models use equations that are designed to emulate as well as possible the many natural forces at play in the earth-atmosphere system. In order to function, a model requires guidance from input data and parameters that steer the model in a particular direction. For example, the concentration of carbon dioxide in the atmosphere is an important climate variable that is often inputted into a model to generate climate projections.

Before the results of climate models can be read and understood, it is necessary to understand the role of carbon dioxide and other greenhouses gases in climate "forcing". The concept of climate forcing is briefly explained in the following paragraph:

The earth's air temperatures are very closely linked to the atmospheric concentration of greenhouse gases, particularly carbon dioxide $\left(\mathrm{CO}_{2}\right)$. This is because greenhouse gases such as $\mathrm{CO}_{2}$ are known to "force" the atmosphere towards warming by increasing the quantity of energy that the atmosphere can trap or store. Forcing is measured in units of Watts per square metre $\left(\mathrm{W} \mathrm{m}^{-2}\right)$, and the forcing value reflects the difference between the amount of energy the earth's atmosphere receives from the sun and the amount of energy the atmosphere returns to space, per square metre of the earth's surface. The value for atmospheric forcing is dependent on the concentration of greenhouse gases in the atmosphere.

In order to make projections for future air temperatures, climate models require information on the future forcing of the atmosphere (via concentrations of $\mathrm{CO}_{2}$ and other greenhouse gases). 
However, future atmospheric forcing is closely linked to societal behaviour and complex environmental feedback processes, which are difficult to predict. As a result, scientists often create a variety of future forcing "scenarios" which reflect different paths that atmospheric greenhouse gas concentrations may follow or intersect with in the future. These different scenarios can then be used to run climate models, thus producing a variety of temperature projections, each associated with a different forcing scenario. Moreover, because air temperatures have a strong influence on other climate-related variables, such as sea ice, sea level, and weather, air temperature projections and climate forcing are used in further models to generate projections for these other climate-related variables. Thus the projections for climaterelated variables other than temperature (e.g. sea ice) will typically be associated with a set of temperature projections and the forcing scenario that created these temperature projections.

\section{* IPCC forcing scenarios}

Forcing scenarios created by the Intergovernmental Panel on Climate Change (IPCC) are frequently used in climate modeling efforts throughout the scientific community. By creating multiple scenarios, the IPCC attempts to encapsulate the range of possibilities for society's future climate forcing and for the resultant increases in atmospheric temperatures (Cubasch et al., 2013). While any one of the scenarios is unlikely to be precisely correct, a relatively accurate sense of the future possibilities for atmospheric temperature can be gained by evaluating and comparing the range of projections.

Several IPCC forcing scenarios were used to create some of the projections presented in this assessment. They are briefly introduced below:

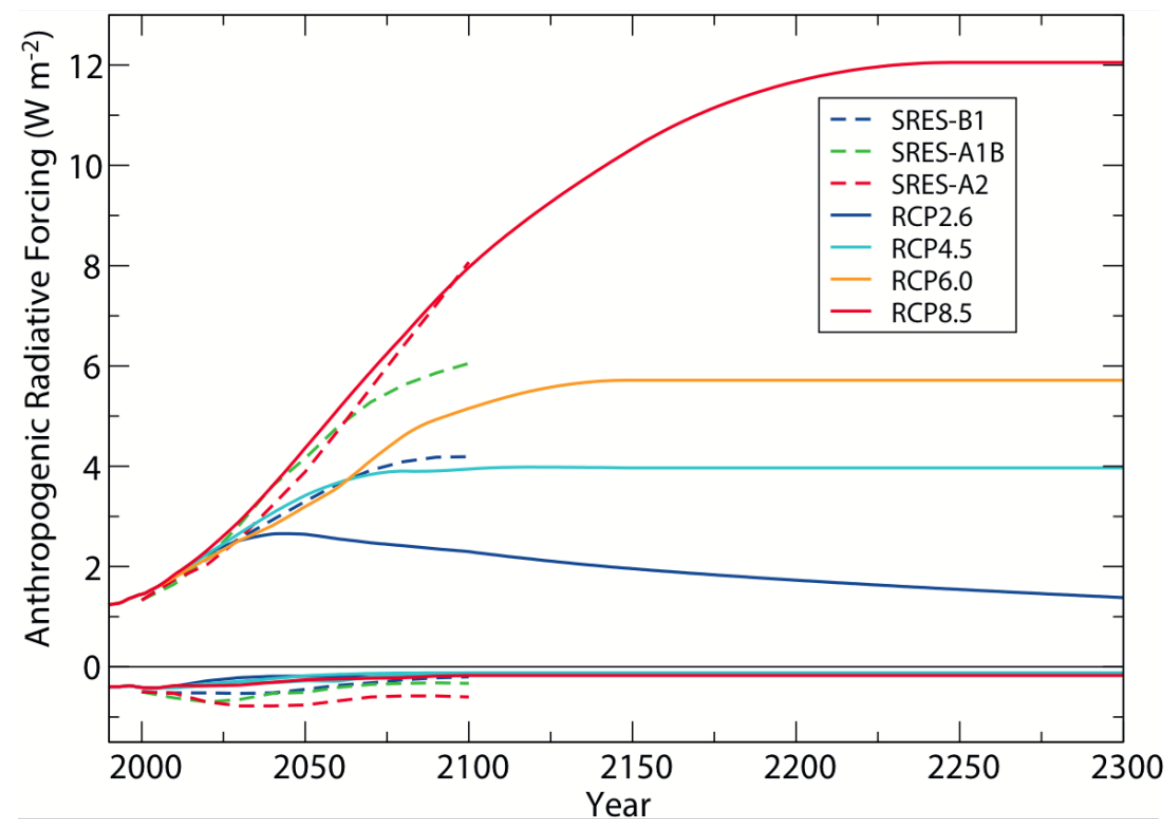

Figure 6.20: The change in atmospheric forcing (W m-2) between 2000 and 2300 under various IPCC forcing scenarios. "SRES" scenarios were in use from 2000-2012, RCP scenarios were finalized for the 2013 IPCC Report (Cubasch et al., 2013). From Collins et al., (2013). 


\section{IPCC 2013: Representative Concentration Pathway (RCP) Scenario 4.5}

The RCP 4.5 scenario is considered a "medium-low" forcing pathway, which involves stabilization of atmospheric forcing at $4.5 \mathrm{~W} \mathrm{~m}^{-2}$ near the year 2100 (Cubasch et al., 2013). In this scenario, the atmospheric concentration of $\mathrm{CO}_{2}$ rises from 389.1 parts per million (ppm) in 2010 to $538.4 \mathrm{ppm}$ in 2100; this rise in concentration is rapid at first but declines to near zero by the end of the $21^{\text {st }}$ century $(I P C C, 2013)$. The " $\mathrm{CO}_{2}$ equivalent" concentration $\left(\mathrm{CO}_{2 \mathrm{e}} \mathrm{ppm}\right)$, which incorporates the concentrations of all greenhouse gases (Methane, Nitrous Oxide, etc...) by converting them into the $\mathrm{CO}_{2}$ concentration that would have an "equivalent" forcing effect, rises from roughly $400 \mathrm{CO}_{2 \mathrm{e}} \mathrm{ppm}$ in 2000 to just under $600 \mathrm{CO}_{2 \mathrm{e}}$ ppm by 2100 (Cubasch et al., 2013).

Table 6.7: The change in $\mathrm{CO} 2$ and $\mathrm{CO} 2$ equivalent concentrations between 2000 and 2100 under the RCP 4.5 Scenario (IPCC, 2013; Cubasch et al., 2013).

\begin{tabular}{|c|c|c|}
\hline RCP 4.5 Scenario & $\mathrm{CO}_{2}(\mathrm{ppm})$ & $\mathrm{CO}_{2}$ equivalent $\left(\mathrm{CO}_{2 \mathrm{e}} \mathrm{ppm}\right)$ \\
\hline Year 2000 & 368.9 & $\sim 400$ \\
\hline Year 2050 & 486.5 & $\sim 510$ \\
\hline Year 2100 & 538.4 & $\sim 595$ \\
\hline
\end{tabular}

2. IPCC 2013: Representative Concentration Pathway (RCP) Scenario 8.5

The RCP 8.5 scenario is the highest of the IPCC's 2013 scenarios. In the RCP 8.5 scenario, forcing reaches $8.3 \mathrm{~W} \mathrm{~m}^{-2}$ by the year 2100 and is still rising rapidly at this point (Collins et al., 2013). The scenario's projections for future atmospheric concentrations of $\mathrm{CO}_{2}$ and $\mathrm{CO}_{2}$ equivalent are listed in the table below:

Table 6.8: The change in $\mathrm{CO} 2$ and $\mathrm{CO} 2$ equivalent concentrations between 2000 and 2100 under the RCP 8.5 Scenario (IPCC, 2013; Cubasch et al., 2013).

\begin{tabular}{|c|c|c|}
\hline RCP 8.5 Scenario & $\mathrm{CO}_{2}(\mathrm{ppm})$ & $\mathrm{CO}_{2}$ equivalent $\left(\mathrm{CO}_{2 \mathrm{e}} \mathrm{ppm}\right)$ \\
\hline Year 2000 & 368.9 & $\sim 400$ \\
\hline Year 2050 & 540.5 & $\sim 700$ \\
\hline Year 2100 & 935.9 & $\sim 1100$ \\
\hline
\end{tabular}

3. IPCC 2000: Special Report on Emissions Scenarios (SRES) A2 ("high") and B1 ("low") The IPCC SRES were used in IPCC reports until the most recent IPCC series of reports began to be published in 2013. Until quite recently the SRES were used to force climate models and as a result these scenarios are an integral part of many recent scientific publications.

Table 6.9: The change in $\mathrm{CO} 2$ and $\mathrm{CO} 2$ equivalent concentrations between 2000 and 2100 under two IPCC SRES scenarios (IPCC, 2013; Cubasch et al., 2013).

\begin{tabular}{|c|c|c|}
\hline SRES A2 “high" & $\mathrm{CO}_{2}$ (ppm) & $\mathbf{C O}_{2}$ equivalent $\left(\mathrm{CO}_{2 \mathrm{e}} \mathbf{p p m}\right)$ \\
\hline Year 2000 & 368 & $\sim 400$ \\
\hline Year 2050 & 527 & $\sim 500$ \\
\hline Year 2100 & 846 & $\sim 950$ \\
\hline SRES B1 “low" & $\mathrm{CO}_{2}(\mathrm{ppm})$ & $\mathrm{CO}_{2}$ equivalent $\left(\mathrm{CO}_{2 \mathrm{e}} \mathrm{ppm}\right)$ \\
\hline Year 2000 & 368 & $\sim 400$ \\
\hline Year 2050 & 485 & $\sim 480$ \\
\hline Year 2100 & 544 & $\sim 590$ \\
\hline
\end{tabular}




\subsubsection{Air Temperature Projections}

\section{A. Extrapolation of trends from section 6.2. "Trends and Variability"}

The temperature trends presented in section 6.2 were divided into three groups: Surface air temperature trends for the land area surrounding the Hudson Bay Complex (Hochheim and Barber, 2014), surface air temperature trends above the ocean (computed using NCEP reanalysis data), and Churchill temperature trends (computed by analysis of Environment Canada weather station data). Not all of these trends will be extrapolated and presented here, but a representative group of trends from each section will be examined. The trends, and their extrapolation to 2030 and 2050 are presented below:

Table 6.10: Projected increase in average temperature by 2030 and 2050 predicted by extrapolation of some of the trends presented in section 6.2 "Trends and Variability". Note: although the end dates for data used to calculate the trends vary from 2010 to 2013, for the sake of extrapolation it was assumed that these trends persisted to 2015 . This allowed the calculations for the hypothetical temperature increase to begin at 2015 for all trends.

\begin{tabular}{|c|c|c|c|c|}
\hline & Description & $\begin{array}{l}\text { Historical Trend } \\
\text { ( }{ }^{\circ} \mathrm{C} \text { per decade) }\end{array}$ & $\begin{array}{l}\text { Temperature } \\
\text { change }\left({ }^{\circ} \mathrm{C}\right) \\
2015-2030\end{array}$ & $\begin{array}{c}\text { Temperature } \\
\text { change }\left({ }^{\circ} \mathrm{C}\right) \\
2015-2050\end{array}$ \\
\hline \multirow{4}{*}{$\begin{array}{l}\text { Surface air temperature } \\
\text { trends for the land area } \\
\text { surrounding Hudson Bay }\end{array}$} & $\begin{array}{c}\text { Hudson Bay Fall } \\
(1980-2010)\end{array}$ & +0.8 & +1.2 & +2.8 \\
\hline & $\begin{array}{l}\text { Hudson Bay Spring } \\
\quad(1980-2010)\end{array}$ & \multicolumn{3}{|c|}{ No clear trend } \\
\hline & $\begin{array}{l}\text { Hudson Strait Fall } \\
\qquad(1980-2010)\end{array}$ & +1.5 & +2.3 & +5.3 \\
\hline & $\begin{array}{l}\text { Hudson Strait Spring } \\
\qquad(1980-2010)\end{array}$ & +0.8 & +1.2 & +2.9 \\
\hline \multirow{4}{*}{$\begin{array}{l}\text { Surface air temperature } \\
\text { trends above the ocean }\end{array}$} & $\begin{array}{l}\text { Hudson Bay Summer } \\
\text { (1979-2013) }\end{array}$ & +0.6 & +0.9 & +2.1 \\
\hline & $\begin{array}{l}\text { Hudson Bay Fall } \\
(1979-2013)\end{array}$ & +1.4 & +2.1 & +4.9 \\
\hline & $\begin{array}{c}\text { Foxe Basin Winter } \\
(1979-2013)\end{array}$ & +1.0 & +1.5 & +3.5 \\
\hline & $\begin{array}{l}\text { Foxe Basin Fall } \\
(1979-2013)\end{array}$ & +1.6 & +2.4 & +5.6 \\
\hline \multirow{2}{*}{$\begin{array}{l}\text { Churchill temperature } \\
\text { trends }\end{array}$} & $\begin{array}{c}\text { Annual Average } \\
(1970-2014)\end{array}$ & +0.5 & +0.8 & +1.8 \\
\hline & $\begin{array}{c}\text { Winter Average } \\
(1970-2014)\end{array}$ & +0.6 & +1.0 & +2.2 \\
\hline
\end{tabular}

Temperature projections made using extrapolation make no account for potential future changes in the many factors currently affecting atmospheric temperature, such as atmospheric forcing and societal emissions. We have presented these extrapolations only to indicate what would happen 
with temperatures in the Hudson Bay Complex if current trends were to persist, and to provide some context for the climate model projections which are presented below.

\section{B. Surface air temperature projections from climate models}

1. IPCC 2013 Temperature Projections for 2016-2035

Using forcing scenario RCP4.5 (described in section 6.3.1), the IPCC produced a set of very broad resolution projections for the increase in temperature for 2016-2035 relative to 1986-2005 (Kirtman et al., 2013). These projections are provided on a global scale and no projections specific to the Hudson Bay Complex area available. However, the large-scale projections for the area containing the Hudson Bay Complex indicate surface air temperature increases of roughly $4^{\circ} \mathrm{C}$ for winter and $2^{\circ} \mathrm{C}$ for summer for 2016-2035 relative to 1986-2005 (Kirtman et al., 2013). It would not be accurate to differentiate between the three areas of the Hudson Bay Complex using these projections because the model's uncertainty is too high to provide reliable regional forecasts. However, these projections can be used to provide a rough idea of the short-term warming that may be expected in the area as a whole.

2. The Canadian Regional Climate Model 4 (CRCM4) projections for 2005 to 2100 based on RCP4.5 and RCP8.5 as presented by the Department of Fisheries and Oceans (DFO)

The Canadian Centre for Climate Modelling and Analysis (CCCma), a division of the Climate Research Branch of Environment Canada, maintains a number of climate models. One of these models is the Canadian Regional Climate Model (CRCM), which can be used to make temperature projections for regions within Canada. CRCM4 was recently run and produced hindcasts back to 1961 and future projections to 2065 for air temperatures in Hudson Bay. The future projections were made using the IPCC RCP 4.5 and 8.5 scenarios (Steiner et al., 2013).

Hindcasts from 1961 to 2005 produced using CRCM4 show a range in annual average temperature in Hudson Bay, with values near $3^{\circ} \mathrm{C}$ in the south and $-9^{\circ} \mathrm{C}$ in the north. $\mathrm{CRCM} 4$ predicts temperatures to rise more rapidly in the north. This is representative of a general trend towards greater warming at higher latitudes. For example, CRCM4 predicts an increase of $5-6^{\circ} \mathrm{C}$ in the annual average temperature between 2005 and 2065 in Hudson Bay, while the rest of North America averages a predicted increase of $3-6^{\circ} \mathrm{C}$ (Steiner et al., 2013).

Simulations using CRCM4 estimate a historical warming trend of $0.48^{\circ} \mathrm{C}$ per decade in the annual average temperature of Hudson Bay between 1961 and 2005. The model projected that this trend would increase under both the RCP4.5 and RCP8.5 scenarios, rising to $0.94^{\circ} \mathrm{C}$ per decade (RCP 4.5) and $0.9^{\circ} \mathrm{C}$ per decade (RCP8.5) for the time period between 2012-2061. It is somewhat surprising that RCP4.5 produces a stronger warming trend for Hudson Bay during this time period, however RCP8.5 does show a stronger warming trend when the time frame is extended to 2100 (Steiner et al., 2013). 
Table 6.11: The historical trends and projections for annual average surface air temperature in Hudson Bay produced using CRCM4 (from Steiner et al., 2013). Temperature projections used the IPCC's 2013 scenarios RCP4.5 and RCP8.5. Trends were multiplied with the length of the two time periods to obtain the corresponding temperature changes.

\begin{tabular}{|c|c|c|c|}
\hline \multicolumn{4}{|c|}{ Historical Trend $(1961-2005)=+0.48^{\circ} \mathrm{C}$ per decade } \\
\hline \multicolumn{2}{|c|}{$\begin{array}{l}\text { Projected trends and corresponding } \\
\text { temperature change }\end{array}$} & $\begin{array}{r}\text { 2012-2061 } \\
\text { (50 years) }\end{array}$ & $\begin{array}{l}1961-2100 \\
\text { (140 years) }\end{array}$ \\
\hline \multirow{2}{*}{ RCP 4.5} & $\begin{array}{c}\text { Trend } \\
\left(\left({ }^{\circ} \mathrm{C} \text { per decade }\right)\right.\end{array}$ & +0.94 & +0.64 \\
\hline & $\begin{array}{l}\text { Temperature } \\
\text { Change }\left({ }^{\circ} \mathrm{C}\right)\end{array}$ & +4.7 & +8.96 \\
\hline \multirow{2}{*}{ RCP 8.5} & $\begin{array}{c}\text { Trend } \\
\left({ }^{\circ} \mathrm{C} \text { per decade }\right)\end{array}$ & +0.90 & +0.93 \\
\hline & $\begin{array}{l}\text { Temperature } \\
\text { Change }\left({ }^{\circ} \mathrm{C}\right)\end{array}$ & +4.5 & +13.02 \\
\hline
\end{tabular}

It is worth noting that even a "medium-low" scenario such as RCP4.5 is predicting a rise of $4.7^{\circ} \mathrm{C}$ in annual average temperature in Hudson Bay by 2061. Further temperature predictions by CRCM4 using the RCP8.5 scenario are represented in some detail in Figure 6.21 (Steiner et al., 2013) and briefly summarized below:

- Map A presents the average annual temperature for the years 1986-2005.

- Map B presents the average increase between the annual average from 1966-1985 and 19862005. The areas of the Hudson Bay Complex show estimated increases of $0-2^{\circ} \mathrm{C}$.

- Map $\mathrm{C}$ shows a projected increase of $0-2^{\circ} \mathrm{C}$ for the Hudson Bay Complex in the annual average temperatures of $2006-2025$ vs. 1986-2005.

- Map D shows a projected increase of $3-8^{\circ} \mathrm{C}$ for the Hudson Bay Complex in the annual average temperatures of 2046-2065 vs. 1986-2005.

- Maps $\mathrm{E}$ and $\mathrm{F}$ shows the increases in the average monthly temperatures of May and November for the time periods $2046-2065$ vs. 1986-2005. Map E indicates increases of 0-4 ${ }^{\circ} \mathrm{C}$ during May while map F indicates increases of $2-8^{\circ} \mathrm{C}$ in November.

As a final note, it should be mentioned that for both scenarios CRCM4 simulations predict the most rapid warming to take place in the winter months of January, February, and March in the Hudson Bay system (Steiner et al., 2013). 
A) $1986-2005$ Annual

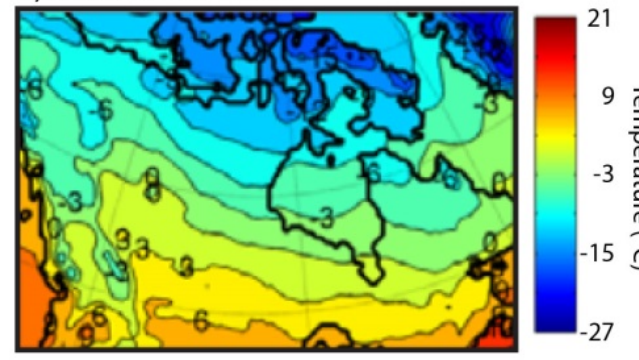

C) 2006-2025 minus 1986-2005 Annual

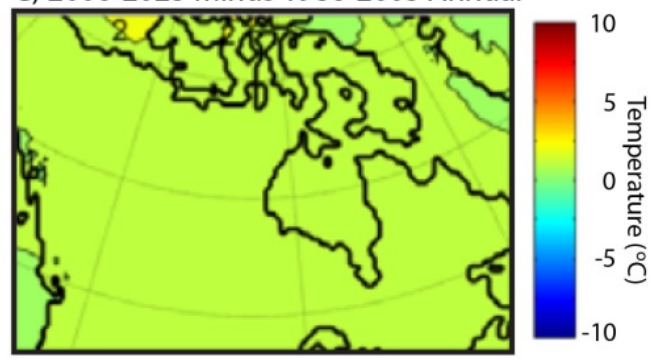

E) 2046-2065 minus 1986-2005 May

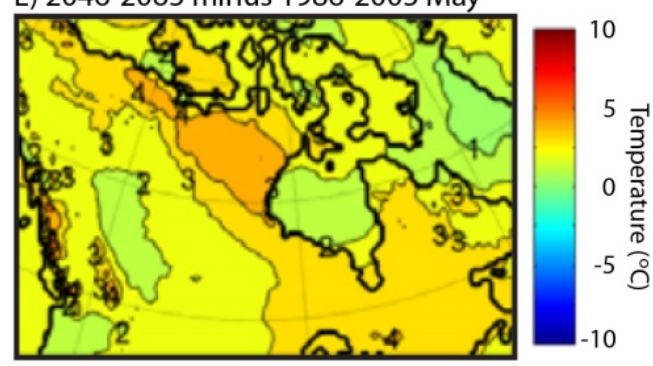

B) 1986-2005 minus 1966-1985 Annual

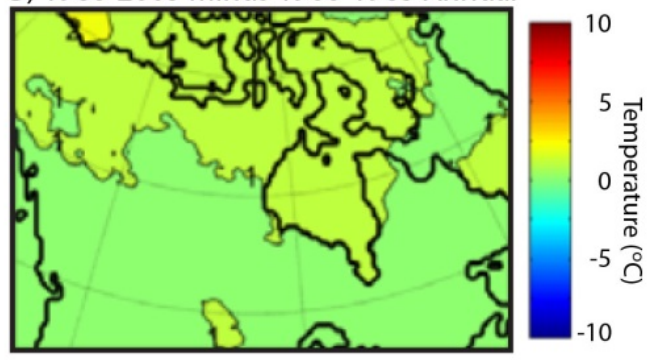

D) 2046-2065 minus 1986-2005 Annual

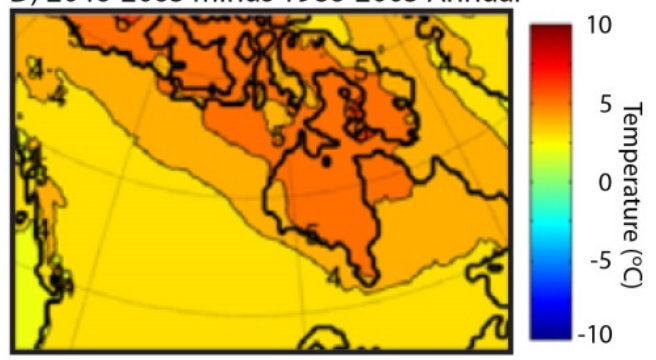

F) 2046-2065 minus 1986-2005 November

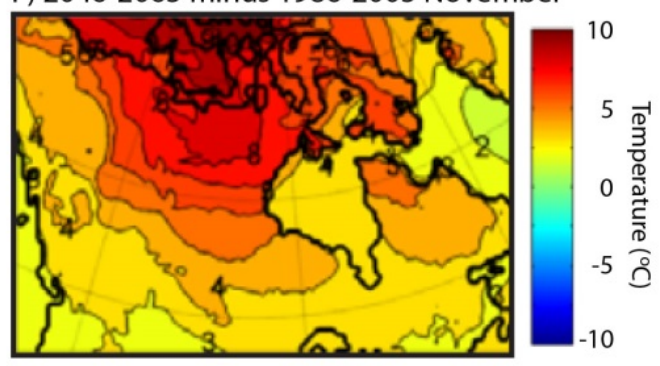

Figure 6.21: CRCM4 projections for surface air temperature in the Hudson Bay Complex, created using the IPCC's RCP 8.5 scenario. Adapted from Steiner et al., 2013.

3. Canadian Regional Climate Model (CRCM) projections for 2041-2070 based on the IPCC's SRES A2 scenario as presented by Joly et al., (2011)

Joly et al., (2011) also made use of the Canadian Regional Climate Model 4 (CRCM4), although these authors forced the model using the IPCC SRES A2 scenario (a "high" forcing scenario). The authors were particularly interested in the temperature projections for the Hudson Bay Complex for the years 2041-2070, during which time the SRES A2 scenario called for a $\mathrm{CO}_{2}$ concentration of 707-950 ppm (Joly et al., 2011).

Joly et al., (2011) compared the CRCM4 hindcast results for the period 1961-1990 with the projections for 2041-2070 for temperatures at $2 \mathrm{~m}$ elevation in the Hudson Bay Complex. The data for both 30-year timeframes consisted of temperature estimates at 12 hour intervals. The projected changes in temperature between the two time periods varied significantly amongst seasons, ranging from a rise of $0.8^{\circ} \mathrm{C}$ for July to an increase of $10^{\circ} \mathrm{C}$ for December, with a mean annual warming of $3.9^{\circ} \mathrm{C}$. In general, the colder months display a much larger and more rapid increase in temperature than the warm months (Joly et al., 2011). This is in agreement with the CRCM4 projections produced by Steiner et al. (2013) when the model was forced with the RCP 
scenarios. Figure 6.22 displays a comparison of the temperatures for the two 30 -year time frames as estimated by CRCM4.

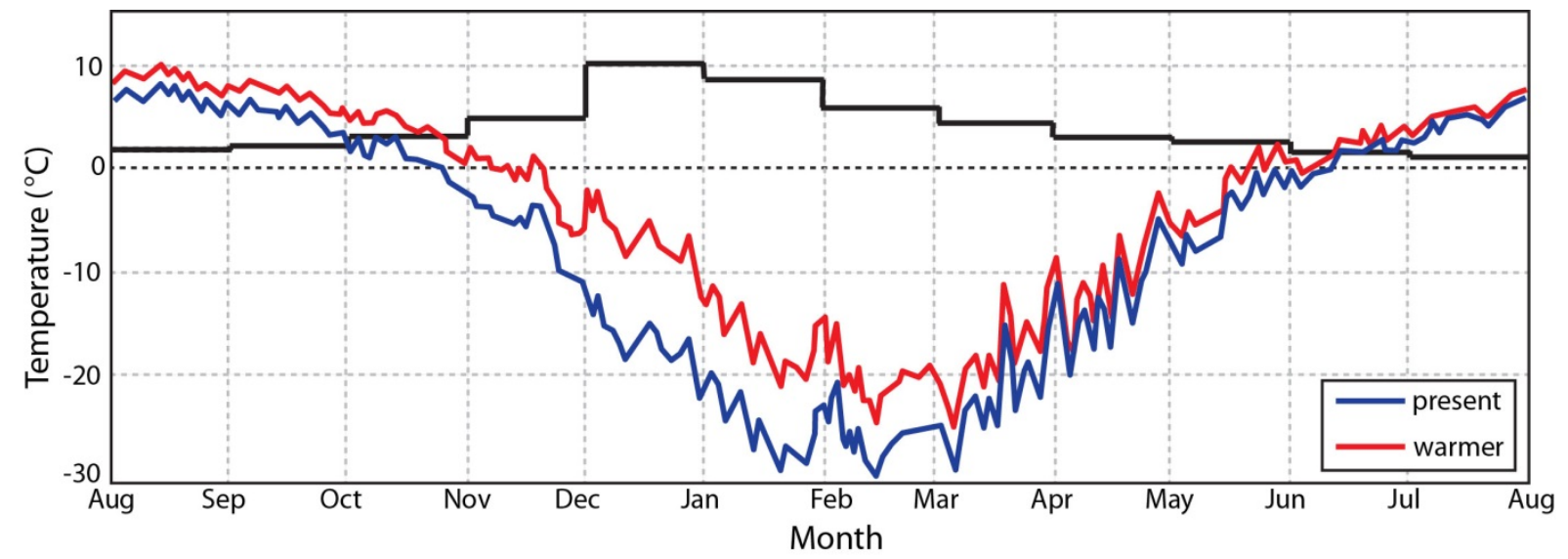

Figure 6.22: A comparison of the CRCM4 temperature estimates for the periods 1961-1990 and 20412070 in the Hudson Bay Complex. Data consists of temperature values at 12 hour time intervals. The blue line ("present") represents the estimates for 1961-1990 while the red line ("warmer") represents 20412070. The black line displays the average difference between the two for each month (Joly et al., 2011).

\subsubsection{Sea Ice Projections}

\section{A. Extrapolation of trends from section 6.2. "Trends and Variability"}

Hochheim and Barber (2014) present several historical trends for sea ice in the Hudson Bay Complex. Three of these trends were chosen for extrapolation to 2030 and 2050:

Table 6.12: Projected changes in the length of the open water season in the Hudson Bay Complex based on extrapolation of results presented in Hochheim and Barber (2014).*Note: representative trends are linear fits based on average changes for 1996-2010 vs. 1980-1995 from Hochheim and Barber (2014).

These trends are estimates and were not reported by Hochheim and Barber (2014).

\begin{tabular}{|c|c|c|c|}
\hline $\begin{array}{c}\text { Mean change in open water season length } \\
\text { for 1996-2010 vs. 1980-1995 (weeks) }\end{array}$ & Hudson Bay & Foxe Basin & Hudson Strait \\
\hline $\begin{array}{c}\text { Representative trend in open water } \\
\text { season length (weeks per year)* }\end{array}$ & +0.10 & +3.5 & +4.9 \\
\hline $\begin{array}{c}\text { Extrapolation to 2030: } \\
\text { Increase in open water season length } \\
\text { between 2010 and 2030 (weeks) }\end{array}$ & +2.1 & +0.12 & +3.3 \\
\hline $\begin{array}{c}\text { Extrapolation to 2050: } \\
\text { Increase in open water season length } \\
\text { between 2010 and 2050 (weeks) }\end{array}$ & +4.1 & +4.7 & +6.5 \\
\hline
\end{tabular}

The projections made using extrapolation presented in Table 6.12 make no account for potential future changes in the many factors currently causing the trends in the open water season length, such as atmospheric temperature and wind forcing. These extrapolations are presented only to indicate what would happen if current trends persist and to provide some context for the model projections presented below. 


\section{B. Sea Ice projections from climate models}

1. Model projections for the ocean's response to a warmer climate in the 2041-2070 time period (Joly et al., 2011).

Joly et al. (2011) made use of the Canadian Regional Climate Model 4 (CRCM4) temperature estimates for 1961-1990 ("present" period) and 2041-2070 ("warmer" period) to model the effect of a warmer climate on the waters of the Hudson Bay Complex (note: temperature projections were created using the IPCC's SRES A2 ("high") scenario and the data is described in section 6.3.2 on page 88). The difference between the 2041-2070 and 1961-1990 temperature estimates from CRCM4 were used to run the ocean model (Joly et al., 2011).

Analysis by Joly et al. (2011) predicts a significant reduction in the length of the sea ice season (and conversely a significant increase in the length of the open water season) in Foxe Basin and Hudson Bay:

Table 6.13: Change in the average timing of freeze-up and breakup date between the 1961-1990

("present") and 2041-2070 ("warmer") climate scenarios as published by Joly et al. (2011).

\begin{tabular}{|c|c|c|c|c|c|}
\hline & \multicolumn{2}{|c|}{ Freeze-up } & \multicolumn{2}{c|}{ Breakup } & New Ice Season \\
& "Present" & "Warmer" & "Present" & "Warmer" & Length \\
\hline Hudson Bay & Dec. $4^{\text {th }}$ & +25 days & July $8^{\text {th }}$ & -24 days & $\sim 5.5$ months \\
\hline Foxe Basin & Nov. $^{\text {th }}$ & +31 days & July 13 & -22 days & $\sim 6.5$ months \\
\hline
\end{tabular}

Note that the results for sea ice concentration and sea ice cover (i.e. extent and presence/absence) presented by Joly et al. (2011) are based on the "median value of sea ice concentration" method described in section 6.2.2.A. This the same method used by Environment Canada in Figure 6.8 (page 59) and different from the method used by Hochheim and Barber (2014).

A change in the open water season length such as that predicted by Joly et al. (2011) would have major implications for the Port of Churchill. Recall that the IPCC's SRES A2 scenario was used to run the ice model and that A2 has the highest atmospheric forcing of the SRES scenarios. Further predictions for sea ice made by Joly et al. (2011) are presented below: 

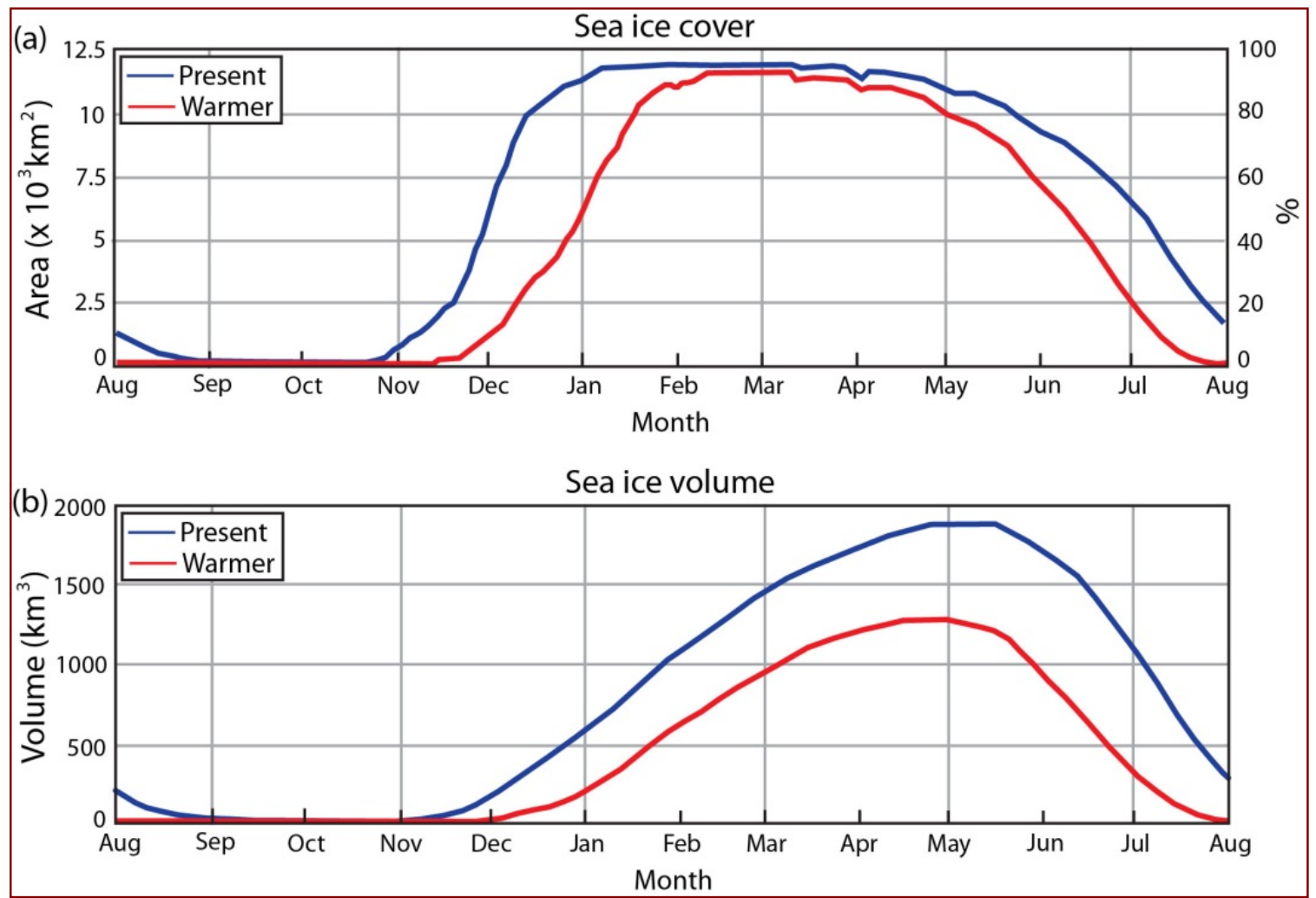

Figure 6.23: Projections for sea ice cover and sea ice volume for the 1961-1990 "present" and 2041-2070 "warmer" periods for the Hudson Bay Complex. Adapted from Joly et al. 2011.

Figures 6.23 and 6.24 both indicate the significant reductions in both late spring/early summer and winter sea ice concentrations predicted by the model used by Joly et al. (2011). Sea ice concentrations in December are predicted to decline to near zero in large areas of the Hudson Bay Complex, including Hudson Strait and southern Hudson Bay (Figure 6.24b). The same is true for areas of northern Hudson Bay, James Bay, and Hudson Strait in June (Figure 6.24d). These figures show once again the projected increase in the duration of the open water season by 2041-2070 under the IPCC's SRES A2 scenario.

Finally, the projected change for sea ice thickness published by Joly et al. (2011) merit some examination. Joly et al. (2011) predict a decline in sea ice thickness throughout the Hudson Bay Complex for 2041-2070 vs. 1961-1990, with the greatest reductions occurring in Hudson Strait and south-eastern Hudson Bay (Figure 6.25). This is in contrast to the trends observed by Gagnon and Gough (2006), who describe a significant increase in landfast sea ice thickness in western Hudson Bay between roughly 1958 and 2003. The two findings are not necessarily incompatible, however. Landfast sea ice and non-landfast sea ice are quite different and the two may be shaped by different environmental influences and may also respond differently to the same influences. It is possible that landfast sea ice and non-landfast sea ice thicknesses could exhibit different trends during the same time frame. 

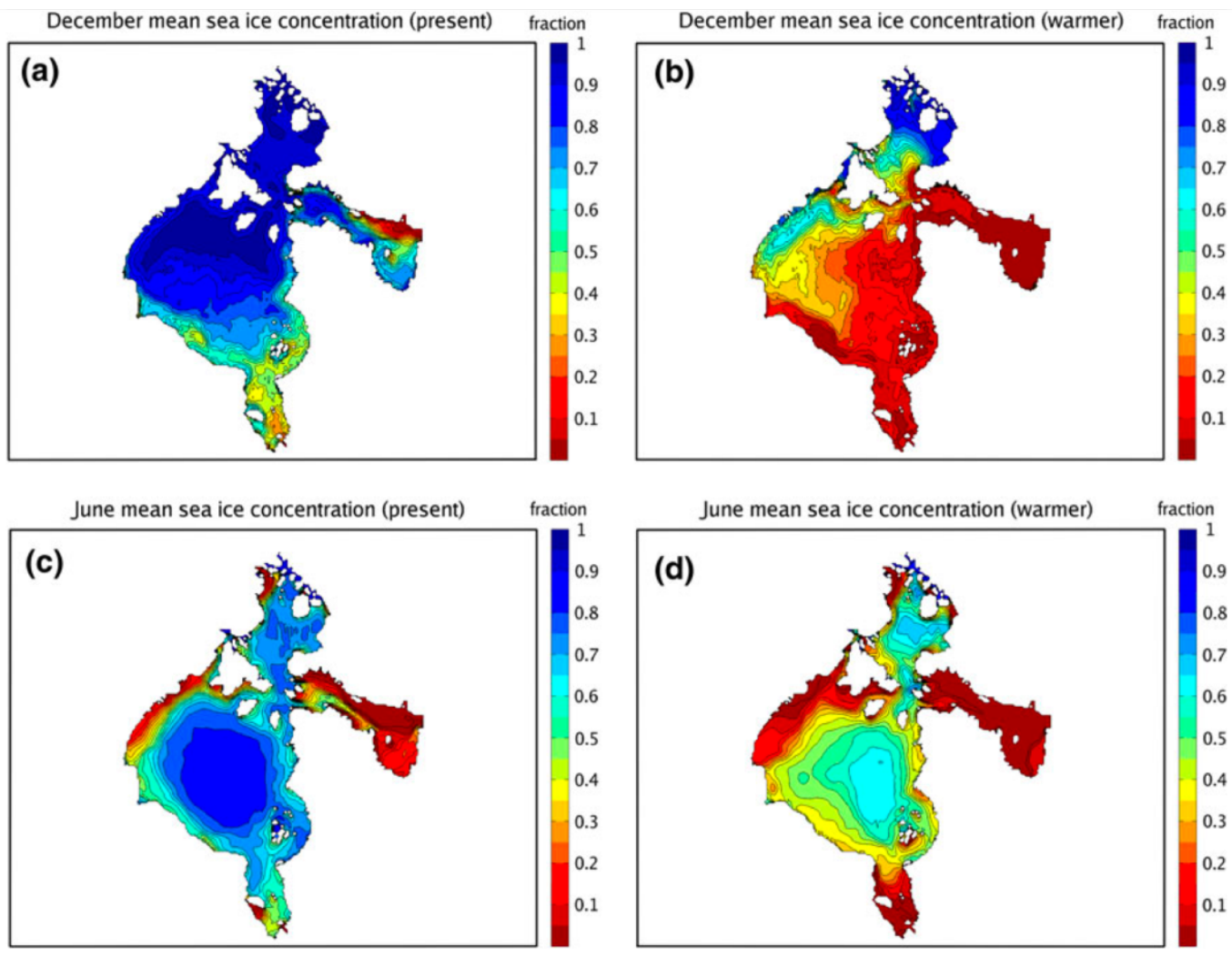

Figure 6.24: Projections for sea ice concentration in the 1961-1990 "present" and 2041-2070 "warmer" time periods for June and December in the Hudson Bay Complex (Joly et al. 2012).

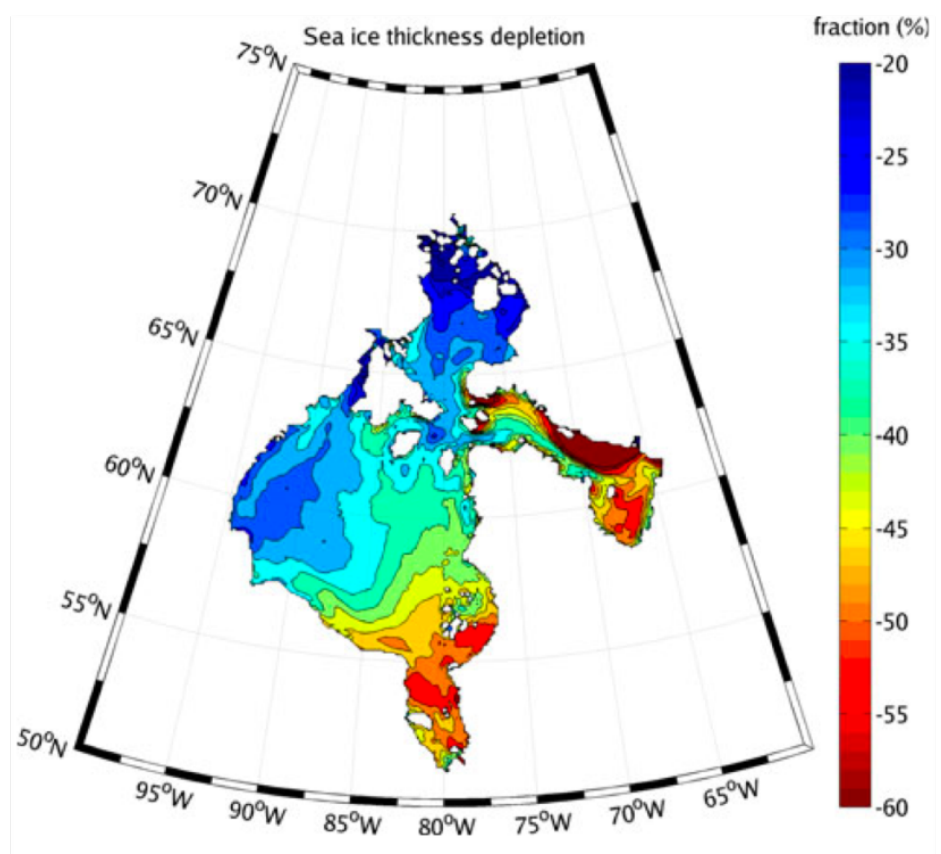

Figure 6.25: The average change in sea ice thickness between 2041-2070 and 1961-1990 for the icecovered months of January, February, March, and April in the Hudson Bay Complex. From Joly et al., 2011. 
2. Sea ice projections for 2006-2050 relative to 1981-2000 produced by the Nucleus for European Modeling of the Ocean (NEMO) model at the University of Manitoba's Centre for Earth Observation Science (CEOS).

The NEMO model was run at CEOS in 2015 to create projections for sea ice concentration and sea ice thickness for the years 2006 to 2050 in the Hudson Bay Complex. The model was run using the IPCC's RCP4.5 scenario. Before discussing the NEMO model's results, it should be mentioned that the model is currently a work in progress at CEOS. The model's projections are in the process of being validated and several changes and updates are planned for the near future. The projections outlined below are the product of an early simulation run of the NEMO model and more developed projections will be available soon. Nevertheless, the early NEMO results agree quite well with the results from Joly et al. (2011). This is further discussed below.

Figures 6.26 and 6.27 present the NEMO model's predictions for the changes in sea ice concentration and sea ice thickness for the period 2006-2050 relative to the model's hindcast estimates for 1981-2000. Note that both figures display the change in the variable being measured, not the actual value.

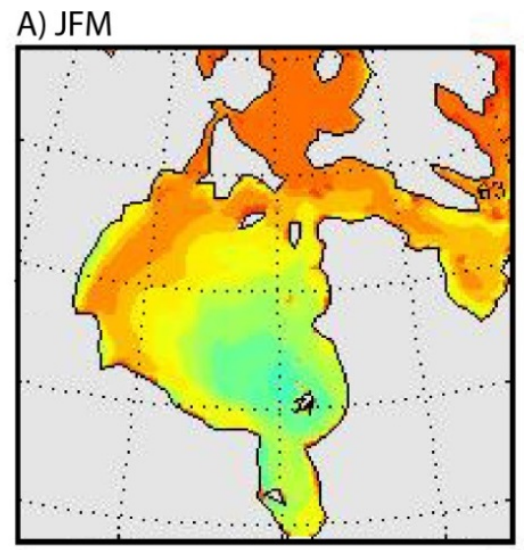

B) AMJ
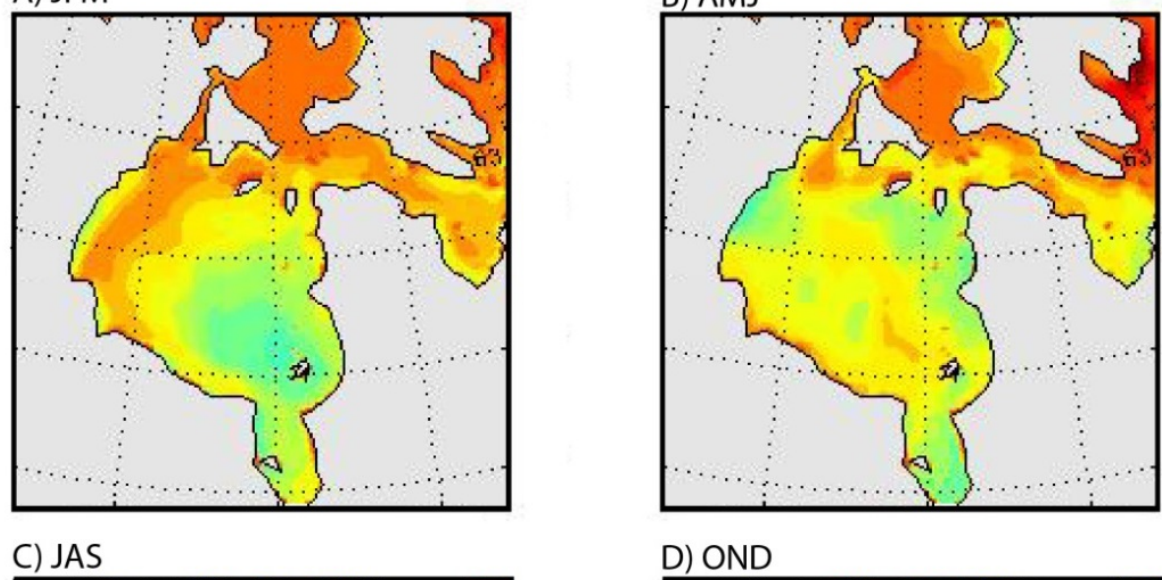

D) OND
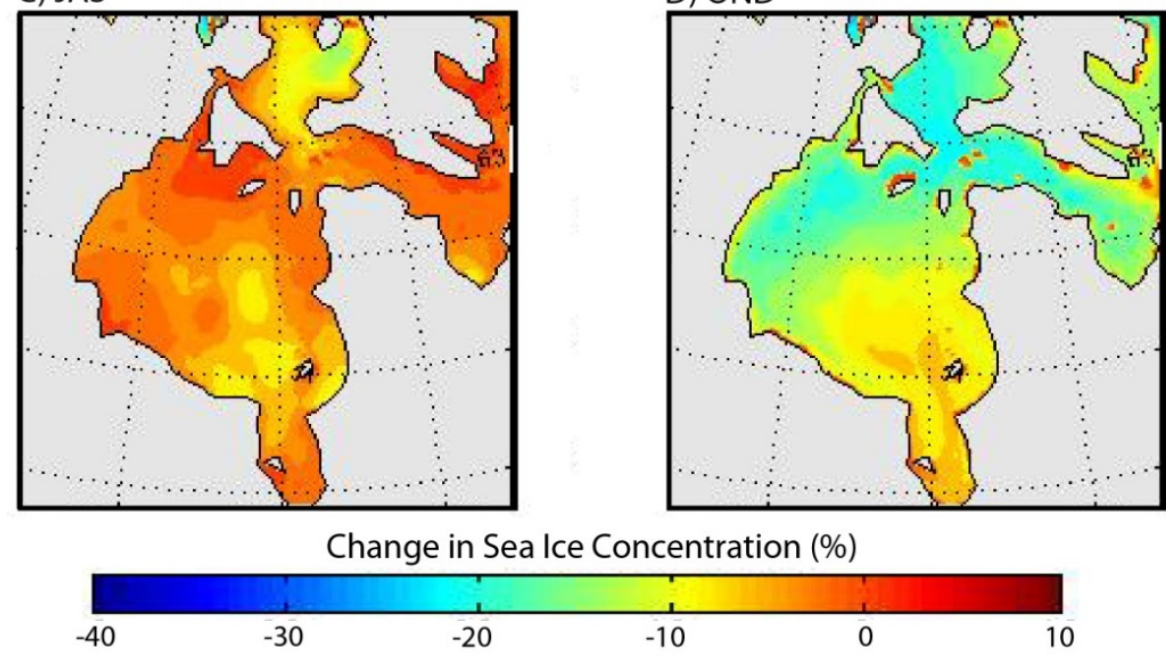

Figure 6.26: The change in seasonal sea ice concentration for the period 2006-2050 relative to 1981-2000 as predicted by the NEMO model at CEOS. 
The NEMO model project a reduction in sea ice concentration for every season in all areas of the Hudson Bay Complex for 2006-2050 relative to 1961-1990. South-eastern Hudson Bay is projected to see the greatest reductions in winter sea ice concentrations $(-25 \%)$. The greatest reductions in spring concentrations are projected for James Bay and north-eastern and northwestern Hudson Bay (-25\%). The greatest reductions in fall concentrations are projected to occur in northern Hudson Bay, Foxe Basin, and Hudson Strait (up to -40\%). Little change (less than $10 \%$ ) is projected for the summer except in Foxe Basin; this is likely because there is little sea ice in the Complex during the summer.

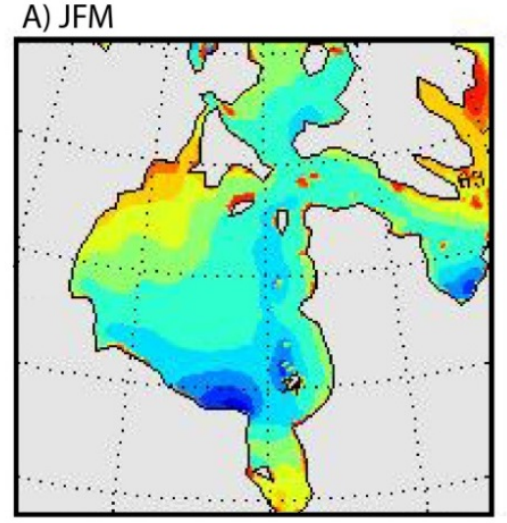

C) JAS

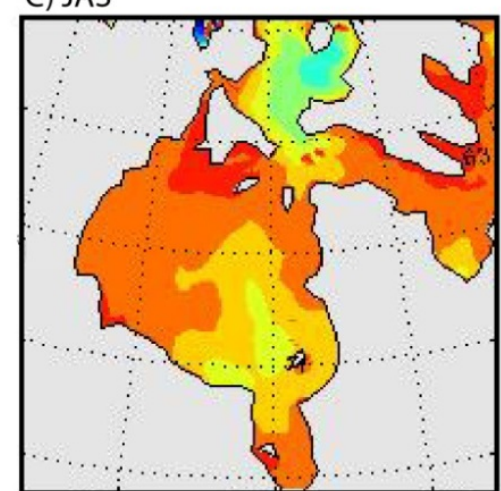

B) AMJ

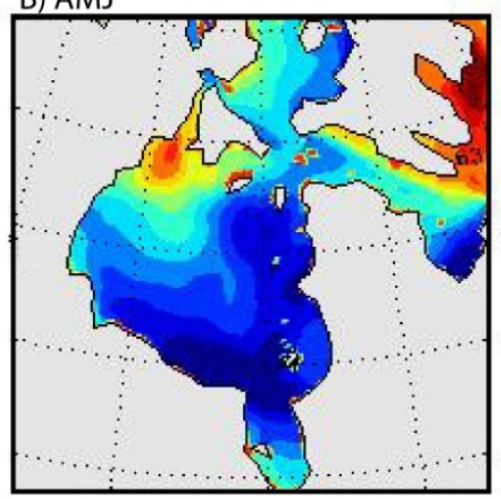

D) OND

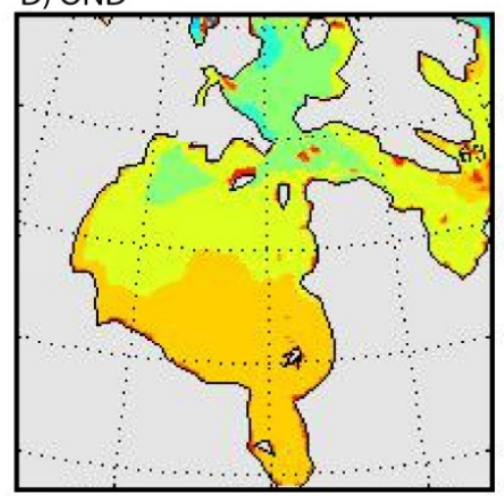

Change in Sea Ice Thickness ( $m$ )

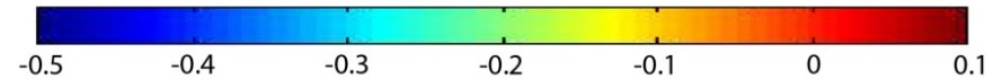

Figure 6.27: The change in seasonal Sea Ice Thickness (metres) for the period 2006-2050 relative to 1981-2000 as predicted by the NEMO model at CEOS.

The NEMO model projects reductions in sea ice thickness in all three areas of the Hudson Bay Complex in each season for 2006-2050 relative to 1981-2000 (Figure 6.27). This is in keeping with the thickness results presented by Joly et al. (2011). The reductions in sea ice thickness projected by the NEMO model are greatest in the winter and spring (up to $-50 \mathrm{~cm}$ ). 


\subsubsection{Sea Level Projections}

As described in section 6.2.3, sea level at the Port of Churchill shows significant variation over two time scales: A long term, multi-year scale and a shorter-term, seasonal scale. We can examine the two time scales separately when considering predictions for the future.

Projections for long-term sea level variation:

- On a multi-year timescale, sea level in Churchill appears to have become more-or-less constant as the sea-level raising influence of climate change has begun to offset the effect of isostatic rebound (Gough and Robinson, 2000). There are few scientific projections for sea level on a multi-year timescale in Hudson Bay, but Gough (1998) suggests that sea level near Churchill is unlikely to fall much further and will more likely remain roughly constant or may even begin to rise within the next 100 years. No specific details are provided with this hypothesis (Gough 1998). At this point we can only conclude that the Port of Churchill is unlikely to experience significant changes in long-term sea level by 2030 or 2050 .

Projections for short-term sea level variation:

- On a seasonal timescale, the sea level at the Port of Churchill undergoes an annual cycle with an amplitude of roughly $300 \mathrm{~mm}$, with lows in early spring and peaks around October (Gough et al., 2005). The timing and amplitude of this cycle are thought to be a product of river discharge and are likely influenced by climate change and hydroelectric regulation (Gough et al., 2005). As a result, both the timing and amplitude of the cycle may be subject to changes in the future. No studies were found that quantitatively project the possible change in the seasonal fluctuations of sea level in Churchill or Hudson Bay. However, studies have been conducted examining the past trends and possible future scenarios for river discharge into Hudson Bay. Déry et al. (2011) found a positive trend in the total river discharge into Hudson Bay from the mid-1980s until the study's end in 2008. The authors suggested that this may be a result of climate warming and thus could continue as warming progresses. Moreover, Déry et al. (2011) noted a shift in the timing of river discharge into Hudson Bay, moving towards higher volumes in the winter and lower spring freshets, and attributed this to hydroelectric activity. Both of these factors could result in shifts in the short-term sea level variations at the Port of Churchill and in Hudson Bay, but there is too much uncertainty for any accurate projections to be made at present.

\subsubsection{Projections for Adverse Weather}

There is little published work presenting projections for adverse weather in the Hudson Bay Complex. The few sources that could be found are discussed below.

\section{A. Storms}

Savard et al. (2014) provide projections for several characteristics of the storm regime in the Hudson Bay Complex for 2041-2070 vs. 1961-2000 using 8 different model simulations based 
on the IPCC's SRES A2 scenario. Some of the authors' key findings are outlined below (Savard et al., 2014):

- The models projected no discernible change in the average annual number of cyclonic centres in the Hudson Bay Complex. However, the models do project a $25 \%$ increase in the number of cyclone centres during December and January. No significant change was projected for any other months.

○ Note: the term "cyclonic centre" refers to the area at the centre of the low pressure system. While this metric does not directly equate to storms, cyclonic centres are the locations of storm occurrence, thus an increase in cyclonic centres would suggest an increase in storms.

- Models also projected an increase in the number of cyclone trajectories moving through the Hudson Bay Complex in December and January. No change was projected for the number of cyclone trajectories in any other months.

- Finally, the models projected an increased residence time for storms above Hudson Bay during December and January

The authors theorize that the projected increases in cyclone centres, trajectories, and residence times for the months of December and January are a product of open water, and thus stormsupporting conditions, persisting later into the year (Savard et al., 2014). In effect, the "storm season" is projected to lengthen in response to an extension of the open water season.

Savard et al. (2014) suggest that the projected changes in the storm regime of 2041-2070 vs. 1961-2000 for December and January could have a significant impact on their study area of Northern Quebec (or Nunavik) and more generally on coastal infrastructure throughout the Hudson Bay Complex. The authors predict that with the extension of the open water season and an apparent extension of the storm season there could be an increase in the energy of waves reaching the coast of Hudson Bay, particularly in the late fall (December) when storms are projected to occur more often and persist for longer. Savard et al. (2014) further suggest that these climate change-caused alterations to the storm regime will increase the frequency of extremely high water levels along the eastern coast of Hudson Bay, in James Bay, and in Hudson Strait. Furthermore, the authors predict a more frequent co-occurrence of high water levels and strong waves in these locations. Finally, Savard et al. (2014) project an increase in the frequency of storm surges for the study villages of Northern Quebec (or Nunavik) in the future, especially in fall and winter.

\section{B. Wind Speed}

1. Wind Speed Projections for Hudson Bay Complex from the Canadian Regional Climate Model 4 (CRCM4)

The CRCM4 simulation produced projections for wind speed squared $\left(\mathrm{m}^{2} \mathrm{~s}^{-2}\right)$, a predictive metric related to wind speed (Steiner et al., 2013). CRCM4 projected an increase of $0.17 \mathrm{~m}^{2} \mathrm{~s}^{-2}$ per decade between 1961 and 2100 under the RCP8.5 scenario and an increase of $0.08 \mathrm{~m}^{2} \mathrm{~s}^{-2}$ under RCP4.5 for the same time frame; both trends are statistically significant (Steiner et al., 
2013). For the RCP8.5 scenario, these increases are fairly uniform throughout the Hudson Bay Complex, although wind speeds in the eastern part of Hudson Strait are predicted to increase more rapidly than other areas. In summary, according to Steiner et al. (2013) wind speeds are projected to increase throughout the Hudson Bay Complex from 1961 to 2100. 


\section{References}

Canadian Coast Guard. (2012). Ice Navigation in Canadian Waters. Retrieved from Government of Canada, Canadian Coast Guard Website: http://www.ccggcc.gc.ca/Ice_home/Ice_Publications/Ice-Navigation-in-Canadian-Waters

Collins, M., R. Knutti, J. Arblaster, J.-L. Dufresne, T. Fichefet, P. Friedlingstein, X. Gao, W.J. Gutowski, T. Johns, G. Krinner, M. Shongwe, C. Tebaldi, A.J. Weaver and M. Wehner, 2013: Long-term Climate Change: Projections, Commitments and Irreversibility. In: Climate Change 2013: The Physical Science Basis. Contribution of Working Group I to the Fifth Assessment Report of the Intergovernmental Panel on Climate Change [Stocker, T.F., D. Qin, G.-K. Plattner, M. Tignor, S.K. Allen, J. Boschung, A. Nauels, Y. Xia, V. Bex and P.M. Midgley (eds.)]. Cambridge University Press, Cambridge, United Kingdom and New York, NY, USA

Cubasch, U., D. Wuebbles, D. Chen, M.C. Facchini, D. Frame, N. Mahowald, and J.-G. Winther, 2013: Introduction. In: Climate Change 2013: The Physical Science Basis. Contribution of Working Group I to the Fifth Assessment Report of the Intergovernmental Panel on Climate Change [Stocker, T.F., D. Qin, G.-K. Plattner, M. Tignor, S.K. Allen, J. Boschung, A. Nauels, Y. Xia, V. Bex and P.M. Midgley (eds.)]. Cambridge University Press, Cambridge, United Kingdom and New York, NY, USA

Déry, S. J., Mlynowski, T. J., Hernández-Henríquez, M. A., \& Straneo, F. (2011). Interannual variability and interdecadal trends in hudson Bay streamflow. Journal of Marine Systems, 88(3), 341-351.

Environment Canada (2013a). Adjusted and Homogenized Climate Data (AHCCD) [webpage]. Retrieved from Government of Canada, Environment Canada website: http://www.ec.gc.ca/dccha-ahccd/

Environment Canada (2013b). Homogenized Surface Wind Speed Data [dataset]. Retrieved from Government of Canada, Environment Canada website: http://www.ec.gc.ca/dcchaahccd/default.asp?lang=en\&n=552AFB3E-1

Environment Canada (2013c). Adjusted Precipitation Data [dataset]. Retrieved from Government of Canada, Environment Canada website: http://www.ec.gc.ca/dcchaahccd/default.asp?lang=en\&n=9AA530BE-1

Environment Canada (2013d). Sea Ice Climatic Atlas for the Northern Canadian Waters 19812010 [webpage]. Retrieved from Government of Canada, Environment Canada website: https://www.ec.gc.ca/glaces-ice/default.asp?lang=En\&n=4B35305B$1 \&$ offset $=1 \&$ toc $=$ show

Environment Canada (2014). Historical Climate Data [data set]. Retrieved from Government of Canada, Environment Canada website: http://climate.weather.gc.ca/data_index_e.html

Fisheries and Oceans Canada (2015). Canadian Tides and Water Levels Data Archive [data set]. Retrieved from http://www.isdm-gdsi.gc.ca/isdm-gdsi/twl-mne/index-eng.htm\#s5 
Gachon, P., Aider, R., Martin, P., Saad, C., Gagnon, S., Cotnoir, A. (2011). Storm tracks activities over the Hudson Bay area and links with surface extremes: past and future changes [Presentation slides]. Retrieved from: www.drinetwork.ca/extremes2011/gachon.pdf

Gagnon, A. S., \& Gough, W. A. (2005). Trends in the dates of ice freeze-up and breakup over hudson Bay, canada. Arctic. 370-382.

Gagnon, A. S., \& Gough, W. A. (2006). East-west asymmetry in long-term trends of land-fast ice thickness in the Hudson Bay region, Canada. Climate Research, 32(3), 177.

Gough, W. A. (1998). Projections of sea-level change in hudson and james Bays, canada, due to global warming. Arctic and Alpine Research, 30(1), 84-88.

Gough, W. A., Gagnon, A. S., \& Lau, H. P. (2004). Interannual variability of Hudson Bay ice thickness. Polar Geography, 28(3), 222-238.

Gough, W. A., \& Robinson, C. A. (2000). Sea-level variation in Hudson Bay, Canada, from tidegauge data. Arctic, Antarctic, and Alpine Research, 331-335.

Gough, W. A., Robinson, C., \& Hosseinian, R. (2005). The influence of James Bay river discharge on Churchill, Manitoba sea level. Polar Geography, 29(3), 213-223.

Ingram, R. G., Wang, J., Lin, C., Legendre, L., \& Fortier, L. (1996). Impact of freshwater on a subarctic coastal ecosystem under seasonal sea ice (southeastern Hudson Bay, Canada). I. Interannual variability and predicted global warming influence on river plume dynamics and sea ice. Journal of Marine Systems, 7(2), 221-231.

Hanesiak, J.M., X.L. Wang (2005). Adverse-weather trends in the Canadian Arctic, J. Climate, 18, 3140-3156.

Hochheim, K. P., \& Barber, D. G. (2014). An update on the ice climatology of the Hudson Bay system. Arctic, Antarctic, and Alpine Research, 46(1), 66-83. doi:10.1657/1938-424646.1.66

Hochheim, K., Barber, D. G., \& Lukovich, J. V. (2010). Changing sea ice conditions in Hudson Bay, 1980-2005. In A little less Arctic (pp. 39-52). Springer Netherlands.

Hanesiak, J.M., X.L. Wang (2005). Adverse-weather trends in the Canadian Arctic, J. Climate, $18,3140-3156$.

Hanesiak, J., Stewart, R., Taylor, P., Moore, K., Barber, D., McBean, G., ... \& Hudak, D. (2010). Storm studies in the Arctic (STAR). Bulletin of the American Meteorological Society, 91(1), 47

IPCC, 2013: Annex II: Climate System Scenario Tables [Prather, M., G. Flato, P. Friedlingstein, C. Jones, J.-F. Lamarque, H. Liao and P. Rasch (eds.)]. In: Climate Change 2013: The Physical Science Basis. Contribution of Working Group I to the Fifth Assessment Report of the Intergovernmental Panel on Climate Change [Stocker, T.F., D. Qin, G.-K. Plattner, M. Tignor, S.K. Allen, J. Boschung, A. Nauels, Y. Xia, V. Bex and P.M. Midgley (eds.)]. Cambridge University Press, Cambridge, United Kingdom and New York, NY, USA 
Joly, S., Senneville, S., Caya, D., \& Saucier, F. (2011). Sensitivity of Hudson Bay sea ice and ocean climate to atmospheric temperature forcing. Climate Dynamics, 36(9-10), 18351849.

Kirtman, B., S.B. Power, J.A. Adedoyin, G.J. Boer, R. Bojariu, I. Camilloni, F.J. Doblas-Reyes, A.M. Fiore, M. Kimoto, G.A. Meehl, M. Prather, A. Sarr, C. Schär, R. Sutton, G.J. van Oldenborgh, G. Vecchi and H.J. Wang, 2013: Near-term Climate Change: Projections and Predictability. In: Climate Change 2013: The Physical Science Basis. Contribution of Working Group I to the Fifth Assessment Report of the Intergovernmental Panel on Climate Change [Stocker, T.F., D. Qin, G.-K. Plattner, M. Tignor, S.K. Allen, J. Boschung, A. Nauels, Y. Xia, V. Bex and P.M. Midgley (eds.)]. Cambridge University Press, Cambridge, United Kingdom and New York, NY, USA.

Kuzyk, Z., Macdonald, R., Granskog, M., Scharien, R., Galley, R., Michel, C., . . Stern, G. (2008). Sea ice, hydrological, and biological processes in the churchill river estuary region, hudson Bay. Estuarine, Coastal and Shelf Science, 77(3), 369-384.

Manitoba Hydro (n.d.). Churchill Weir [webpage]. Retrieved from: https://www.hydro.mb.ca/environment/projects/fish/churchill_weir.shtml

Manitoba Water Stewardship Division (n.d.). Churchill River Diversion [webpage]. Retrieved from: http://www.gov.mb.ca/waterstewardship/licensing/churchill_river_diversion.html

Ricketts, S., \& Hudson, H. (2001). Climatology and Forecasting Hazardous Weather in Canada's Arctic. Government of Canada, Meteorological Service of Canada. Retrieved from: https://ams.confex.com/ams/pdfpapers/21123.pdf

Saucier, F. J., \& Dionne, J. (1998). A 3-D coupled ice-ocean model applied to hudson Bay, canada: The seasonal cycle and time-dependent climate response to atmospheric forcing and runoff. Journal of Geophysical Research: Oceans (1978-2012), 103(C12), 2768927705.

Savard, J-P., Gachon, P., Rosu, C., Aider, R., Martin, P., Saad, C. (2014, October). Impact des changements climatiques sur le régime des tempêtes, les niveaux d'eau et les vagues dans le Nunavik. Retrieved from: http://www.ouranos.ca/media/publication/357_RapportSavard2014.pdf

Sepp, M., \& Jaagus, J. (2011). Changes in the activity and tracks of arctic cyclones. Climatic Change, 105(3-4), 577-595.

St-Laurent, P., Straneo, F., Dumais, J. F., \& Barber, D. G. (2011). What is the fate of the river waters of Hudson Bay?. Journal of Marine Systems, 88(3), 352-361.

Steiner, N., Azetsu-Scott, K., Galbraith, P., Hamilton, J., Hedges, K., Hu, X., . . . , van der Baaren, A. (2013). Climate Change Assessment in the Arctic Basin Part 1: Trends and Projections - A Contribution to the Aquatic Climate Change Adaptation Services Program. Retrieved from Government of Canada, Department of Fisheries and Oceans website: http://www.dfo-mpo.gc.ca/library/350169.pdf 
Stewart, D.B., \& Lockhart, W.L. (2005). An Overview of the Hudson Bay Marine Ecosystem. Retrieved from Government of Canada, Department of Fisheries and Oceans website: http://www.dfo-mpo.gc.ca/libraries-bibliotheques/toc-tdm/314704-eng.htm

Tivy, A., Howell, S. E., Alt, B., Yackel, J. J., \& Carrieres, T. (2011). Origins and levels of seasonal forecast skill for sea ice in Hudson Bay using Canonical Correlation Analysis. Journal of Climate, 24(5), 1378-1395.

Vermaire, J. C., Pisaric, M. F., Thienpont, J. R., Courtney Mustaphi, C. J., Kokelj, S. V., \& Smol, J. P. (2013). Arctic climate warming and sea ice declines lead to increased storm surge activity. Geophysical Research Letters, 40(7), 1386-1390.

Wang, R., McCullough, G. K., Gunn, G. G., Hochheim, K. P., Dorostkar, A., Sydor, K., \& Barber, D. G. (2012). An observational study of ice effects on Nelson River estuarine variability, Hudson Bay, Canada. Continental Shelf Research, 47, 68-77.

Wolf, D., Klemann, V., Wünsch, J., \& Zhang, F. P. (2006). A reanalysis and reinterpretation of geodetic and geological evidence of glacial-isostatic adjustment in the Churchill region, Hudson Bay. Surveys in Geophysics,27(1), 19-61. 


\section{$\underline{\text { Section C. Climate-related Vulnerabilities and Opportunities }}$}

\section{The Port of Churchill's Vulnerabilities and Opportunities}

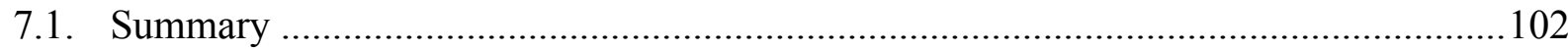

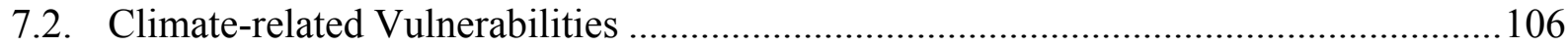

7.2.1. Context: The Challenges of Arctic Shipping ....................................................106

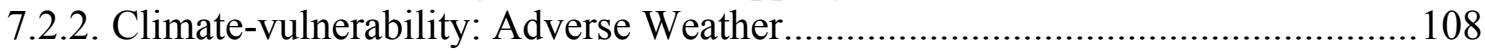

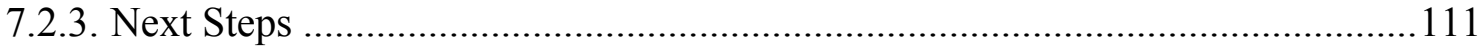

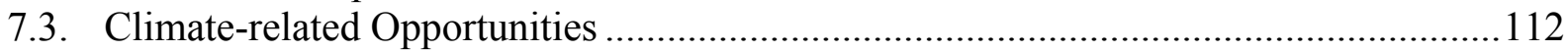

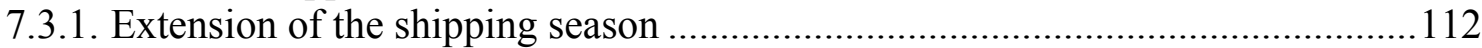

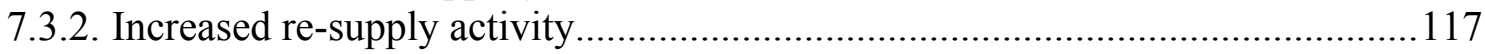

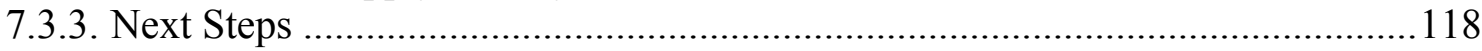

7.4. The Hudson Bay Complex's Ecological Vulnerabilities to Shipping Activity .............119

7.4.1. The pathways of effects for shipping and port operations .................................119

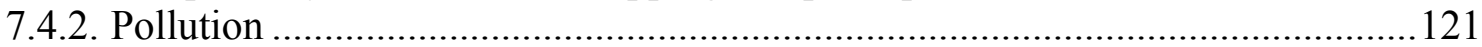

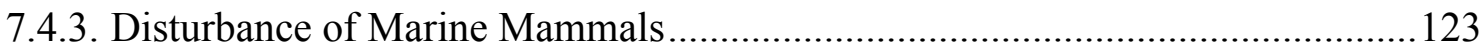

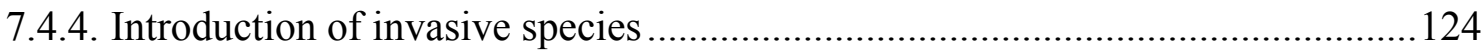

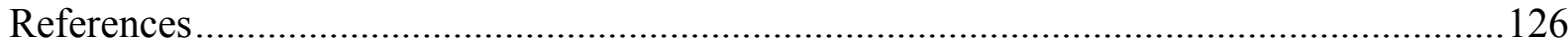

The following discussion of vulnerabilities and opportunities focuses on the Port of Churchill's marine shipping operations. This includes all vessel activity, from loading and docking at the Port to sailing through the Hudson Bay Complex, but does not include the infrastructure and operations of the Port itself. The Port's site-specific climate-related vulnerabilities were the focus of a recent climate-vulnerability assessment completed by the International Institute for Sustainable Development (IISD) and the University of Winnipeg, supported by Stantec Consulting Ltd. (Stantec). Roger Rempel, the Senior Environmental Engineer who spearheaded the project, can be contacted for more information (RogerRempel@mac.com).

\subsection{Summary}

\section{Vulnerabilities}

\section{A. Context: The challenges of Arctic shipping}

- Many of the challenges of shipping in the Canadian Arctic were outlined in the introduction section. This section briefly examines two challenges in further detail.

- Limited Hydrographic Data

- Only a few small areas of the Hudson Bay Complex have been surveyed to "modern" or "adequate" standards (Office of the Auditor General of Canada, 2014).

- Limited Search and Rescue capacity

- It has been reported that the Canadian Search and Rescue system is currently struggling to provide adequate service to the Arctic region, and that without 
adjustments the system will lack the capacity to meet the growing demand for services expected in the future (Goegebeur, 2014).

\section{B. Adverse weather}

- Wind

○ According to 1991-2011 average values, the loading of grain could be hampered by wind on roughly $57 \%$ of the days in the shipping season while docking operations could be made dangerous by wind on roughly $10 \%$ of the days of the shipping season. These results are based on authors' assumed wind thresholds of 30 and $50 \mathrm{~km} \mathrm{~h}^{-1}$, respectively (results determined by analysis of weather station measurements ordered from Environment Canada).

- With regard to winds, the months of September, October, and November are the most challenging for docking and loading operations, while winds are most conducive to port operations during July and August (results determined by analysis of weather station measurements ordered from Environment Canada).

- Projections and extrapolations (Steiner et al., 2013; Environment Canada weather station data) suggest that wind disruption of shipping operations could become more common at the Port of Churchill.

- Precipitation

○ Precipitation falls on roughly half (49\%) of the days of the shipping season.

- There is a general tendency towards an increasing risk of precipitation disruption at the Port of Churchill in the early months of the season and a declining risk of precipitation disruption in the later part of the season (results determined by analysis of weather station measurements ordered from Environment Canada).

- Precipitation related delays would be relatively rare in November, should grain shipping become more common in that month (results determined by analysis of weather station measurements ordered from Environment Canada).

- Low Visibility

- Fog occurred in Churchill with an average monthly frequency of roughly $11 \%$ in July, 10\% in August and September, 7\% in October, and 5\% in November between 1953 and 2004 (Hanesiak and Wang, 2005). The future frequency of fog events is difficult to predict.

- Storms

- The current storm regime may disrupt shipping related operations at the Port and within the Complex during an estimated 10 to 18 days of the shipping season.

- Projections for increased storminess in the months of December and January (Savard et al., 2014) suggest that the Port of Churchill may sustain more storm-related damage during those months.

\section{Next Steps}


- Further research in several areas could help elaborate the assessment of the Port of Churchill's future climate-related vulnerabilities. These research areas include:

- Adverse weather

- The prevalence of "Ice Hazards" in the Hudson Bay Complex.

- The timing of, and factors controlling ice in the Churchill River Estuary.

\section{Opportunities}

\section{A. Extension of the shipping season}

- Between 1980 and 2010 the open water season along the shipping route to the Port of Churchill averaged a length of 114 days, running from July $16^{\text {th }}$ to November $5^{\text {th }}$ (16.3 weeks) (Environment Canada, 2013a).

- With trends toward longer open water seasons, it is likely that in the past 15 years the grain-shipping route was often ice-free outside of the 1980-2010 average dates of July $16^{\text {th }}$ and November $5^{\text {th }}$.

- Over the past 15 years, sea ice timing in the Complex has often permitted a longer shipping season than the one actually used by the Port.

- There is clearly an opportunity to extend the Port of Churchill's grain shipping season where sea ice is concerned. The open water season in the Port's grain-shipping route averaged 16.3 weeks from 1980-2010 and will likely grow beyond a minimum of 18.4 weeks by 2030 and 20.4 weeks by 2050 .

- Research does not indicate that adverse weather may hinder an extension in the shipping season.

\section{B. Increased re-supply activity}

- Current and projected environmental and economic conditions in the Hudson Bay Complex are highly favourable for an expansion and diversification of the Port of Churchill's resupply activity.

\section{Next Steps}

- Further development in two areas of Arctic science in particular could help achieve the realization of a longer shipping season for the Port of Churchill by 2030 or 2050:

- Scientific evidence for a longer and lengthening open water season along the Port's shipping route.

$\circ$ Sea ice forecasting

\section{Ecological Vulnerabilities to Shipping Activity}
A. The Pathways of Effects (POEs) for Shipping and Port Operations
- POEs for shipping (CSAS 2014b)
- POEs for port operation and construction (CSAS 2014c) 


\section{B. Pollution}

- Operation-associated discharge of contaminants

- Shipping vessels and port operations can pollute marine waters through the discharge of anti-foulants and hydrocarbons (CSAS 2014c).

- Large-scale discharge of contaminants caused by shipping accident or wreckage

○ The ecological risk of shipping potash in the Arctic appears to be a significant unknown.

○ The Hudson Bay Complex is likely highly vulnerable to oil spills. Emergency response capability in the area is quite limited (Goegebeur, 2014), oil's behaviour in ice-covered waters is poorly understood (Barber et al., 2014), and the sensitive ecosystems of the Complex are culturally and biologically significant (CSAS, 2011).

\section{Disturbance of marine mammals}

- Belugas in the Churchill River Estuary

- The large summer aggregation of Belugas in the estuary may be vulnerable to ship strikes, noise stress, and environmental changes related to Port operations.

- Noise disturbance

$\bigcirc$ Noise can influence the communication, migration patterns, foraging efficiency, stress levels, and energy requirements of marine mammals (CSAS, 2014c). Operation associated noise in the Port and along shipping routes may disturb a range of marine mammal species.

\section{Introduction of invasive species}

- The Port of Churchill has the highest risk of environmental consequences from species introduction of all locations in the Canadian Arctic (CSAS, 2012) 


\subsection{Climate-related Vulnerabilities}

7.2.1. Context: the challenges of Arctic shipping ...........................................................106

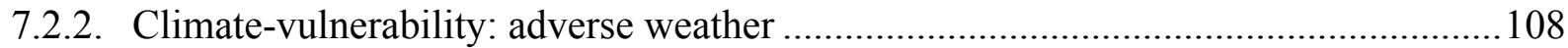

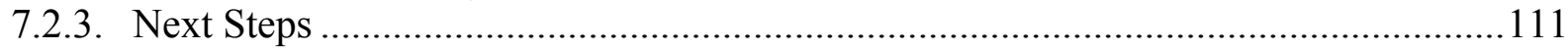

\subsubsection{Context: the Challenges of Arctic Shipping}

Any discussion of climate-related vulnerabilities for the Port of Churchill's shipping operations should be framed in an appropriate context. When considering the Port's operations, it is important to recall the challenges of shipping in the Canadian Arctic. Some of these challenges were outlined in the Introduction Section. For example: the combination of environmental, policy, and insurance factors that limit season length (page 20), and the lack of shipping infrastructure in the Complex (page 19). In this section we will briefly revisit two noteworthy challenges in more detail. These challenges are the lack of hydrographic data in the Canadian Arctic and the Canadian Coast Guard's relatively limited search and rescue capacity in the area.

\section{A. Hydrographic data in the Hudson Bay Complex}

Despite the history of shipping traffic travelling to and from the Port of Churchill and the more general increase in vessel traffic in the Canadian Arctic (detailed in Section 3.2.5), the Auditor General of Canada recently determined that there is insufficient hydrographic data available for the Hudson Bay Complex (Office of the Auditor General of Canada, 2014). In fact, only a few small areas of the Complex have been surveyed to "modern" or "adequate" standards (Figure 7.1). This increases the risk of shipping in the Canadian Arctic, particularly in higher volume areas such as Hudson Strait (Office of the Auditor General of Canada, 2014).

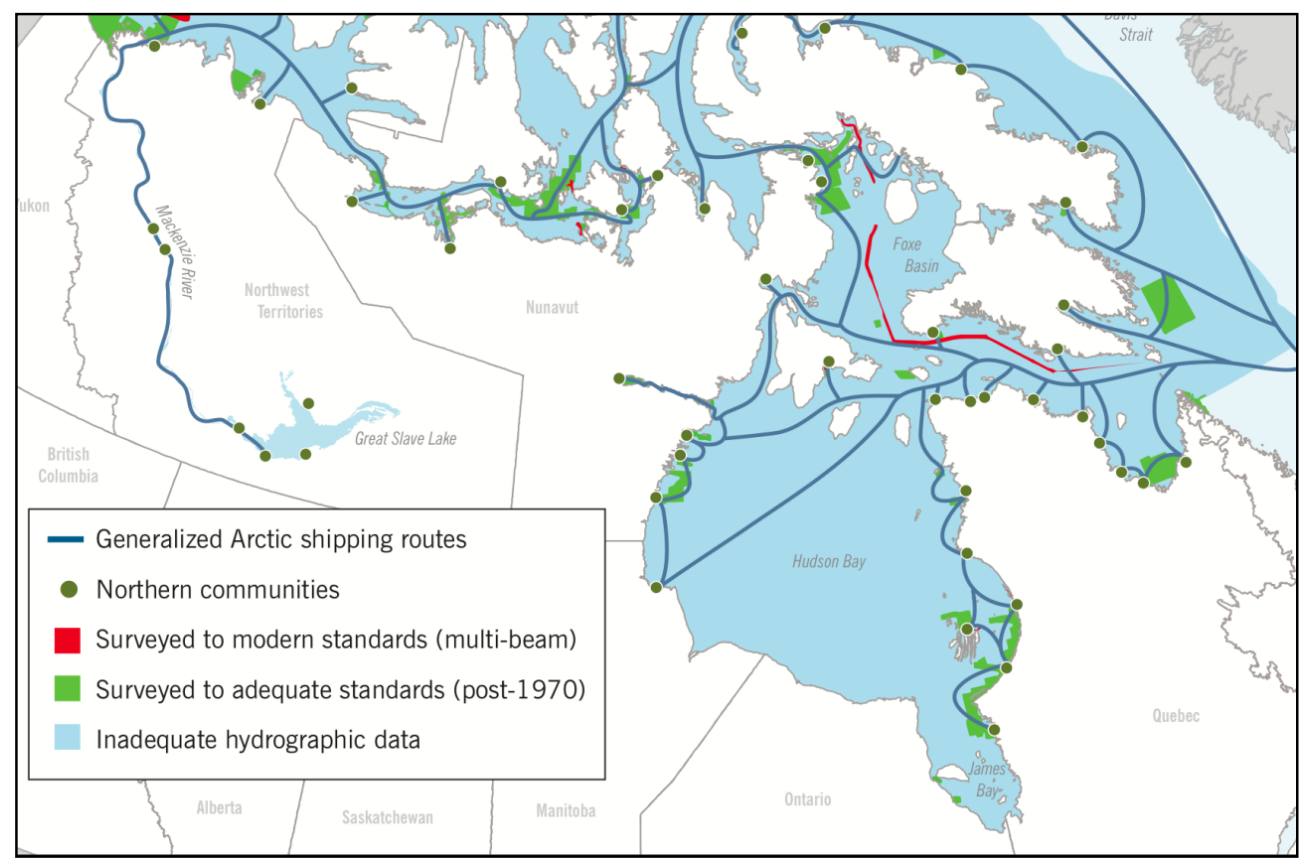

Figure 7.1: The extent of hydrographic surveying in the Eastern Canadian Arctic (Office of the Auditor General of Canada, 2014). 
The Canadian Hydrographic Service (CHS), in collaboration with the Canadian Coast Guard (CCG), has proposed developing designated "Northern Marine Transportation Corridors" throughout the Canadian Arctic. The CHS and CCG plan to consolidate their resources along these corridors to enable safe shipping through the Arctic. The current shipping route through Hudson Strait and across Hudson Bay to the Port of Churchill is slated to be one of the designated transportation corridors. Precise details about this corridor and its expected development timeline are unclear.

\section{Search and Rescue Capacity in the Hudson Bay Complex}

The Canadian Coast Guard and the Canadian Forces are responsible for aeronautical and maritime Search and Rescue services. The Hudson Bay Complex straddles two formally prescribed Search and Rescue regions: Hudson Strait and most of Foxe Basin fall within the eastern region overseen by a rescue centre located in Halifax, while Hudson Bay is within the central region overseen by a centre in Trenton, Ontario (Canadian Coast Guard, 2015). Search and rescue operations in the Hudson Bay Complex can be undertaken by aircraft or icebreaking vessel (Goegebeur, 2014). Canadian Coast Guard icebreakers are present in Hudson Bay and Hudson Strait between July and October, and in Foxe Basin between August and September. During the remaining months of the year the nearest icebreakers are on the Labrador coast or farther south (Canadian Coast Guard, 2015). Rescue aircraft serving the Hudson Bay Complex are based in Trenton or Halifax. The Trenton centre recently converted from Cormorant to Griffon helicopters, and it is suggested that this change significantly reduced the centre's capacity to provide search and rescue to the northern communities within its region (Goegebeur, 2014). The Halifax centre is still equipped with several Cormorant aircraft and is considered more capable of northern rescue (Goegebeur, 2014).

A 2014 assessment conducted by University of Ottawa researcher Brynn Goegebeur examined the capacity of Canada's National Search and Rescue program in the arctic (Goegebeur, 2014). Goegebeur reported that "any attempt to mount even a small scale operation would be difficult, since the region is lacking in even the most basic infrastructure". Moreover, Goegebeur (2014) further stated that the environmental changes caused by climate change will make Arctic search and rescue operations significantly more challenging. This is in the context of increasing resource exploration and shipping activity in the Hudson Bay Complex, which is raising the likelihood of an event requiring search and rescue response (Goegebeur, 2014). Goegebeur (2014) concluded that current Search and Rescue capabilities in the Canadian Arctic are scarcely able to meet service needs and will likely not be sufficient to support the expected increases in demand. 


\subsubsection{Climate-vulnerability: Adverse Weather}

With regards to the infrastructure and operations considered in this assessment, adverse weather will likely have its greatest impact on the docking and loading operations at the Port of Churchill. As discussed in section 3.1, there are many steps involved in the arrival, docking, loading, and departure of vessels at the Port. Vessels must be guided in to the estuary, oriented for docking, loaded with minimal damage or loss of cargo, undocked, oriented for departure, and guided out of the estuary. These operations take place with the assistance of tugboats and a port pilot and can be vulnerable to disruption from adverse weather such as high winds, precipitation, low visibility, and storms (J. Andersen, personal communication, March 13, 2015). High winds and storms could also impact re-supply vessels attempting to unload goods at northern communities (F. Gaudreau, personal communication, March 20, 2015) and shipping vessels at large in the Hudson Bay Complex.

\section{A. High winds}

High winds can make tugboat operations at the Port dangerous or impossible and can disrupt and/or delay the transfer of grain into vessels at the dock. It is the Port Captain's prerogative to halt operations if he or she deems that the winds are too high for safe and successful operations on the water (J. Andersen, personal communication, March 13, 2015).

\section{* High winds at the Port of Churchill}

The following results were presented in the "Trends and Projections" Section and were calculated using either data available online from Environment Canada (2013b) or weather station data ordered directly from Environment Canada.

From 2001 to 2011 the monthly mean (or average) wind speed in Churchill for the shipping season (July to November) was $21 \mathrm{~km} \mathrm{~h}^{-1}$, with a peak value for October $\left(24.0 \mathrm{~km} \mathrm{~h}^{-1}\right)$ and a minimum value for July $\left(17.8 \mathrm{~km} \mathrm{~h}^{-1}\right.$ ) (Table 6.3, page 76). The annual mean wind speed in Churchill increased significantly between 1970 and 2011 at a rate of $0.290 \mathrm{~km} \mathrm{~h}^{-1}$ decade $^{-1}$. No months of the shipping season showed statistically significant trends in monthly mean wind speed between 1970 and 2011.

Although there were no significant trends in monthly mean wind speeds for the months of the shipping season, we found that for 1991-2014 versus 1970-1990 there was an overall tendency towards higher wind speeds and more days with winds reaching selected wind speed thresholds above $30 \mathrm{~km} \mathrm{~h}^{-1}$ (Table 6.5, page 79). Based on the Beaufort Wind Force Scale, we assumed critical thresholds of $30 \mathrm{~km} \mathrm{~h}^{-1}$ (for delay in grain loading and port operations) and $50 \mathrm{~km} \mathrm{~h}^{-1}$ (for dangerous docking-related operations and increased potential to halt port operations). Results are outlined below:

- We find that between 1991 and 2011 grain loading, or the loading of other freight that may blow around, could be hampered by wind on an average of roughly $57 \%$ of shipping-season days (if November is included in the shipping season). 
- Assuming wind speeds greater than $50 \mathrm{~km} \mathrm{~h}^{-1}$ could make docking and tugboat related operations dangerous, Port operations could be made dangerous by wind on an average of roughly $10 \%$ of shipping-season days.

- Between 1970 and 2011 there was a significant increase of 3.6 days decade $^{-1}$ in the number of shipping-season days during which winds reached the $30 \mathrm{~km} \mathrm{~h}^{-1}$ threshold.

- Wind speeds reached the $30 \mathrm{~km} \mathrm{~h}^{-1}$ and $50 \mathrm{~km} \mathrm{~h}^{-1}$ thresholds most often during October and the least often during July.

- The months of September, October, and November were the most challenging for docking and loading operations, while winds were most conducive to port operations during July and August.

\section{* High winds in the Hudson Bay Complex}

In addition to the challenges that high wind speeds pose to docking and loading operations at the Port of Churchill, high wind speeds can also pose difficulties for shipping vessels travelling through the Hudson Bay Complex and conducting re-supply operations in northern communities. When high wind speeds are coupled with low visibility or icy conditions they can be particularly dangerous. Unfortunately, there is little information available on the frequency of high winds over the marine area within the Complex and it is difficult to comment on the potential impact of high winds on marine vessels either heading to or departing from the Port of Churchill.

\section{* Winds in the future}

Wind is a difficult variable to project due to its inherent complexity and variability. Partly as a result of this, there are very few projections for winds in the Hudson Bay Complex. Steiner et al. (2013) projected an increase of between 0.08 and $0.17 \mathrm{~m}^{2} \mathrm{~s}^{-2}$ decade ${ }^{-1}$ for wind speeds in Hudson Bay between 1961 and 2100.

With regard to the loading operations at the Port of Churchill, loading may be disrupted on an increasing number of days if the current trends for strengthening winds continue. For example, if the trend in the number of days per shipping season with winds reaching $30 \mathrm{~km} \mathrm{~h}^{-1}(+3.6$ days decade $^{-1}$ ) is extrapolated from 2011 to 2030 and 2050, hourly wind speed measurements of 30 $\mathrm{km} \mathrm{h}^{-1}$ or more could be recorded on roughly 6.8 more days of the shipping season by 2030 , and roughly 14 more days by 2050 . This eventuality would raise the number of days where loading may be disrupted by wind significantly above the 1991-2011 average of 87 days of the shipping season (this assumes that wind speeds greater than $30 \mathrm{~km} \mathrm{~h}^{-1}$ could disrupt or slow the loading of grain). Note: these extrapolations assume that the frequency trend at the $30 \mathrm{~km} \mathrm{~h}^{-1}$ threshold remains constant while no trends appear in frequency at other thresholds, which is unlikely.

In addition to the significant trend at the $30 \mathrm{~km} \mathrm{~h}^{-1}$ threshold, analysis suggests that there is a broader increasing trend in the number of days with high winds at the Port of Churchill. As Table 6.5 shows (page 79) the average number of days with an hourly wind speed measurement greater than or equal to 30, 40, 50, or $60 \mathrm{~km} \mathrm{~h}^{-1}$ was higher for 1991-2011 than for 1970-1990 at every threshold for almost every month and for the shipping season as a whole. This suggests that wind 
disruption of shipping operations could become increasingly prevalent at the Port of Churchill. While these projections are not refined, they do provide some indication of the Port's future wind vulnerability.

\section{B. Precipitation}

Precipitation can impact the loading of grain into shipping vessels because grain must be kept as dry as possible at all times in order to maintain the quality of the product. Other products, either currently shipped from the Port or potentially shipped in the future, may also need to remain dry (e.g. potash). Precipitation can fall as rain or snow in Churchill during the shipping season. Environment Canada's measurement data for Total Precipitation from the Churchill weather station between 1970 and 2014 were analyzed to examine the Port's vulnerability to precipitation (Table 6.6, page 81).

As mentioned in the "Trends and Projections" Section, total precipitation measurements must be used with caution for comparing precipitation quantities above $0 \mathrm{~mm}$ across inter- and intraannual scales. This is because the measurements include both rain (more dense) and snow (less dense) and thus variation in total precipitation measurements could reflect a change in the amount of both snow and rain or a change in the precipitation ratio of rain to snow. Variation and trends in total precipitation are discussed here but it is important to remember the limitations of the data.

On average precipitation fell on roughly half of the days during the shipping season between 1991 and 2014 (49\%), meaning grain loading was potentially affected by precipitation on roughly half of the days of the season. Between 1970 and 2014 the only statistically significant trends in the monthly percentage of days without precipitation were a decline of $-2.8 \%$ decade $^{-1}$ during July and an increase of $+4.5 \%$ decade $^{-1}$ during November. Over the 44 year time frame these trends suggest an addition of 3.8 days in July with precipitation and potential for delayed or halted grain transfer, and up to 6 more days without precipitation in November. Overall, there is a general tendency towards an increasing risk of precipitation disruption at the Port of Churchill in the early months of the season, and a declining risk of precipitation disruption in the later part of the season (Figure 6.19, page 82). Historically grain has rarely been shipped in November, however these trends show that relatively fewer precipitation related delays can be expected should November grain shipments become more common.

\section{Low Visibility}

\section{* Fog}

Low visibility can be caused by fog or blowing snow. Fog is most common in Churchill during the months of the shipping season and tends to be most common in July, declining in frequency towards October and November (Hanesiak and Wang, 2005). Between 1953 and 2004, fog occurred with an average monthly frequency of roughly $11 \%$ in July, $10 \%$ in August and September, 7\% in October, and 5\% in November (Figure 6.13) (Hanesiak and Wang, 2005). There was a significant decline in the frequency of fog events in the fall from 1953 to 2004 
(Hanesiak and Wang, 2005), suggesting that fog may hinder port operations less frequently in that season in the future. However, fog is caused by cold air passing over open water; because trends towards a delayed freeze-up are projected to continue in the Hudson Bay Complex it is possible that there will be more open water available to interact with cold air during the end of the shipping season, thus potentially increasing the occurrence of fog. Altogether, the development of fog is dependent on a complicated mix of factors and the frequency of fog events is therefore difficult to project.

\section{* Blowing snow}

Blowing snow events did not occur in the months of July, August, and September between 1953 and 2004, and occurred at an average monthly frequency of roughly 3\% in October and $13 \%$ in November during the same time frame (Hanesiak and Wang, 2005). These data suggest that blowing snow is a minor issue for the Port of Churchill's operations, as these events are rare during the shipping season. This may become even more true in the future: the average annual frequency of blowing snow events declined in Churchill from 1953 to 2004, though there were no significant trends on a seasonal timeframe (Hanesiak and Wang, 2005).

\section{Storms}

The combination of high winds, low visibility, large waves, and sea-level surges associated with storms could be problematic for the Port of Churchill's operations both near the Port and across the Complex. As discussed in the "Trends and Projections" Section, storm activity is greatest in the Hudson Bay Complex during the months of August to December (Savard et al., 2014). The Complex's "storm season" overlaps quite closely with the shipping season, in part because both are dependent on open water. September, October, and November typically average roughly 2.5 storms per month while July and August are closer to 2. These storms vary in duration and intensity, but average 3 to 4 days in duration and storm intensity is typically greatest in the fall (Gachon et al., 2011). Taken together, these data indicate that the current storm regime may disrupt shipping related operations at the Port and within the Complex during an estimated 10 to 18 days of the shipping season.

A literature search did not turn up any research predicting a significant change in storm activity in the Hudson Bay Complex during the months of the shipping season for 2030 or 2050. However, storm frequency and length has been projected to increase for December and January, and it has been suggested that this increase could lead to an increase in storm surges and stormdamage to coastal infrastructure throughout Hudson Bay and Hudson Strait during those months (Savard et al., 2014). If these projections are correct, it is possible that storm damage to the Port of Churchill during the months of December and January could increase in the future.

\subsubsection{Next Steps}

Further research in several areas could enable a more detailed characterization of the Port of Churchill's future climate-related vulnerabilities: 
- More data and projections are needed for the current and future frequency of adverse weather in the Hudson Bay Complex. At present there is not enough known about storms in the Hudson Bay Complex to satisfactorily gauge their effect on the Port's operations both now and into the future. A closer study of high winds in the Complex and near the "ports" (or unloading sites) of towns receiving marine re-supply would also be beneficial.

- An examination of "ice hazards" in the Hudson Bay Complex would be worthwhile. Although there is little-to-no multiyear sea ice in the Hudson Bay Complex, the first year ice pack is very dynamic and can become much thicker and stronger through ridging and rafting processes. It is possible that these deformed floes could pose a danger to vessels travelling to and from the Port, especially early in the shipping season when remnant floes become increasingly mobile before they melt out. There is also anecdotal evidence that the rate of iceberg calving from Greenland glaciers has increased, leading to a greater number of icebergs along the approach to Hudson Strait and the Hudson Bay complex.

- Port of Churchill stakeholders might benefit from a study of the factors that influence freezeup and breakup in the Churchill River estuary and an accurate characterization of the variability in the timing of ice in the estuary. Shipping cannot take place at the Port of Churchill if the estuary has a solid ice cover, regardless of whether or not Hudson Bay and Hudson Strait are open. The timing of ice formation within the estuary is subject to a different range of influences than those affecting the sea ice formation within the Bay. In addition to surface air temperature, wind forcing, sea surface temperatures, salinity, etc., ice in the estuary is likely influenced by the flow of the Churchill River and may be subject to variation based on precipitation and possibly hydroelectric regulation. These factors are worth more investigation so that the timing of ice in the estuary can be better understood.

\subsection{Climate-related Opportunities}

Climate change presents several opportunities for the Port of Churchill and marine transportation in the Hudson Bay Complex. Most significantly, the trends toward longer open water seasons and reduced ice cover in the Complex create two clear opportunities for increased activity through the Port of Churchill:

1. An extension of the shipping season

2. Increased re-supply shipping

These two opportunities are thoroughly discussed below.

\subsubsection{Extension of the shipping season}

\section{* Current shipping season (a review)}

As detailed in the introduction (Section 3), the Port of Churchill's current shipping season is roughly 100 days long, extending from late July to early November. Grain-shipping vessels travelling to the Port of Churchill are typically not ice-strengthened. Under the Zone/Date System, non ice-strengthened vessels may operate in Hudson Bay between July $20^{\text {th }}$ and October 
$31^{\text {st }}$ (Minister of Justice, 1985; Figure 3.3, page 21). However, non ice-strengthened vessels can operate outside of these dates under the Arctic Ice Regime Sipping System (AIRSS) when conditions are appropriate (see page 22).

Between 2009 and 2014, grain ships arrived at the Port as early as July $28^{\text {th }}$ (2010) and departed the Port as late as November $2^{\text {nd }}$ (2014) (Table 3.1; J. McEachern, personal communication, November 18, 2014). Re-supply vessels, which are typically ice strengthened, often arrive at the Port one to two weeks before grain shipping vessels (e.g. July $\left.18^{\text {th }}, 2014\right)$ but don't tend to travel to the Port as late into the fall season (F. Gaudreau, personal communication, March 20, 2015). Ice-strengthened grain vessels are available and could be used to extend the shipping season, but the cost is greater and therefore reduces the already relatively narrow profits of grain shipping through the Port (J. McEachern, personal communication, November 18, 2014).

In addition to environmental constraints and legal regulations, the Port of Churchill's shipping season is also constrained by the cost and regulations of shipping insurance and the logistical challenges of getting grain to Churchill. There are initiatives from other groups (e.g. the Province of Manitoba) pursuing progress in these two constraints but they are not included in the following discussion of the potential for an extension in the Port of Churchill's shipping season by 2030 or 2050 . Instead we consider only the direct, physical constraints of sea ice and adverse weather.

\section{* Sea ice timing in the Hudson Bay Complex}

The grain-shipping route to and from the Port of Churchill was reportedly ice-free by an average date of July $16^{\text {th }}$ between 1980 and 2010 (Figure 6.8; Environment Canada, 2013a). The last ice floes in the Complex are typically found in the southeast corner of Hudson Bay and may persist until the end of July or even into August. During fall freeze-up, ice formation typically progresses from the northwest to the southeast, beginning in Foxe Basin during mid-September and in Hudson Bay and Hudson Strait around November $5^{\text {th }}$ (Figure 6.8). Historically, Foxe Basin was entirely ice covered by November $5^{\text {th }}$ while areas of open water persisted in Hudson Bay and Hudson Strait well into December (Environment Canada, 2013a).

In summary, between 1980 and 2010 the open water season potentially accessible to non icestrengthened vessels travelling to or from the Port of Churchill averaged a length of roughly 114 days running from July $16^{\text {th }}$ to November $5^{\text {th }}$ (16.3 weeks) (Environment Canada, 2013a). This open water period would also be accessible to re-supply vessels operating in western Hudson Bay (between Churchill and Kivalliq), while re-supply vessels in Eastern Hudson Bay could, on average, extend beyond November $5^{\text {th }}$ due to the later freeze-up dates. In Foxe Basin, re-supply vessels appear to be limited to a shorter open water season that typically only exists from late August to mid-October (Environment Canada, 2013a).

It is important to note that the dates discussed above represent the 1980 to 2010 averages and that sea ice timing can vary substantially between years, even by as much as several weeks or a month. 


\section{* Trends in sea ice timing in the Hudson Bay Complex}

The 1980-2010 average dates suggest that recent shipping seasons at the Port of Churchill have run quite close to freeze-up and breakup in the Hudson Bay Complex. However, the average values for 1980-2010 mask a shift towards longer open ice periods occurring throughout the Complex during that time frame. According to Hoccheim and Barber (2014), the open water season was an average of 3.1 weeks longer in Hudson Bay, 3.5 weeks longer in Foxe Basin, and 4.9 weeks longer in Hudson Strait for 1996-2010 vs. 1980-1995 (Table 6.2). Within those increases, breakup occurred significantly earlier and freeze-up occurred significantly later in 1996-2010 versus 1980-1995 in all three regions of the Complex (Hoccheim and Barber, 2014). It is therefore likely that the shipping route to the Port was often ice-free outside of Environment Canada's reported 1980-2010 average dates of July $16^{\text {th }}$ and November $5^{\text {th }}$.

Before continuing it should be mentioned that the definitions of freeze-up and breakup used by Hochheim and Barber (2014) are not the same as those used by Environment Canada (2013a) in the calculation of the 1980-2010 average dates discussed above. Nevertheless, because the trends presented by Hochheim and Barber (2014) are relative times instead of firm dates, we will still compare them to Environment Canada's 1980-2010 averages to provide some insight into the possible changes in open water dates; one should simply treat our conclusions with caution.

Because the shipping route was likely ice-free earlier than July $16^{\text {th }}$ and later than November $5^{\text {th }}$ at times during the past decade or more, it follows that sea ice timing in the Complex has sometimes permitted a longer shipping season than the one actually used by the Port. Recall that between 2009 and 2014 the shipping season never began earlier than July $28^{\text {th }}$ or extended later than November $2^{\text {nd }}$. However, the availability of open water earlier or later than historically typical is difficult to predict and could vary from year to year. This might make it difficult for the Port of Churchill to capitalize on periods of open water outside of the historical norm, as could the current shipping regulations, marine insurance, and the challenges of grain delivery to Churchill. Nevertheless, some of these factors may change as the open water season continues to grow and the Port may become better able to profit from longer open water seasons.

\section{* Estimates for the extension of the open water season by 2030 and 2050}

Looking to the future, there is clearly an opportunity to extend the Port of Churchill's shipping season where sea ice is concerned. The results from an extrapolation of the sea ice trends presented by Hochheim and Barber (2014) are presented in Table 6.12 (page 89). Here, we combine the extrapolation results and the Environment Canada (2013a) 1980-2010 average dates for freeze-up and breakup (Table 7.1). Once more, it should be mentioned that Hochheim and Barber (2014) and Environment Canada (2013a) apply different definitions for freeze-up and breakup and thus results produced by combining these two data sources must be treated with caution. 
Table 7.1: Rough estimates for future changes to the length of the open water season along the main route through the Hudson Bay Complex to the Port of Churchill. More details on calculation methods are provided below.

\begin{tabular}{|c|c|}
\hline $\begin{array}{c}\text { Average length of open water season along shipping route from } \\
1980-2010 \text { (Environment Canada, 2013a) }\end{array}$ & $\begin{array}{c}16.3 \text { weeks } \\
\text { (July } 16^{\text {th }} \text { to November } 5^{\text {th }} \text { ) }\end{array}$ \\
\hline $\begin{array}{c}\text { Estimated minimum length of the open water season along } \\
\text { shipping route in } 2030 \text { and } 2050\end{array}$ & $\sim 18.4$ weeks by 2030 \\
$\sim 20.4$ weeks by 2050
\end{tabular}

As discussed, the average length of the open water season along the Port's shipping route between 1980 and 2010 was roughly 16.3 weeks, between July $16^{\text {th }}$ and November $5^{\text {th }}$ (Environment Canada, 2013a). If we assume that the open water season was 16.3 weeks long in 2010, an extrapolation of the trends from Hochheim and Barber (Table 6.12, page 89) would suggest that the open water season for the grain shipping route could grow to roughly 18.4 weeks by 2030 and roughly 20.4 weeks by 2050 . This extension would also be available to re-supply vessels servicing the Kivalliq area from Churchill. Note that this is a relatively crude estimate of the possible extension of the shipping season that makes several significant assumptions. For example, the shipping season was likely more than 16.3 weeks by 2010 . Moreover, it is unlikely the 1996-2010 trends will continue unchanged into the future and quite likely that the trends will accelerate as the climate forcing increases and feedback cycles accelerate warming and ice reduction. In fact, the estimates for open water seasons of 18.4 weeks by 2030 and 20.4 weeks by 2050 could reasonably be viewed as minimum extensions for the future.

The Port will more likely be able to capitalize on an extension of the open water season into the fall (J. McEachern, personal communication, February 18, 2015). Hoccheim and Barber (2014) found an average difference of +1.6 weeks in freeze-up date for Hudson Bay between 1996-2010 and 1980-1995. If this change were to repeat itself for 2010-2025 versus 1996-2010, the average end of the open water season available for grains shipments could extend from November $5^{\text {th }}$ to mid-November by 2025. Applying the same method to break-up dates yields a date of July $1^{\text {st }}$ for 2010-2025.

Climate model projections for the open water season in the Hudson Bay Complex suggest that sea ice reduction will likely be more rapid than the rate indicated by the extrapolation results shown above. For example, using a climate forcing scenario with one of the strongest $\mathrm{CO}_{2}$ forcings of all the scenarios created by the Inter-governmental Panel on Climate Change (IPCC), Joly et al. (2011) found that freeze-up in Hudson Bay would be delayed from December $4^{\text {th }}$ (the average from 1961-1990) to December $29^{\text {th }}$ (the average from 2041-2070), breakup would progress forward from July $8^{\text {th }}$ to June $14^{\text {th }}$, and open water season length would grow to roughly 
30 weeks on average for 2041 to 2070 . Note that Joly et al. (2011) are using yet another set of sea ice data and different definitions for freeze-up and breakup.

\section{Adverse weather in an extended season}

Research does not indicate that adverse weather may hinder an extension in the Port of Churchill's shipping season:

\section{- Fall extension into November and December}

November does typically have a relatively high number of days with winds above 30 or $50 \mathrm{~km} \mathrm{~h}^{-}$

1 , but these numbers are roughly equal to those typical for September and are lower than those typical for October (Table 6.4, page 77). December appears to have fewer days with strong winds than November. While the number of days with strong winds appears to be increasing in November and December, the rates of increase for each month appear to be similar to those for most of the other months of the shipping season and lower than the rate of increase for September (Table 6.5, page 79).

November (with 56\%) and December (with 66\%) have higher 1991-2014 average percentages of days without precipitation than all months from July to October. Moreover, the proportion of days per month without precipitation decreased at a significant rate of 0.045 (or $4.5 \%$ ) per decade for November between 1970 and 2011 (results determined by analysis of weather station data from Environment Canada). This corresponds to an addition of nearly 6 more days without precipitation from 1970 to 2011. December showed no significant trend in days without precipitation, but already averaged the most of all months between 1991-2014 (Table 6.6, page 82). The months of November and December appear to have a low risk of operations disruption from precipitation, both for now and into the future.

November and December typically have fewer days with fog than the earlier months of the season (Hanesiak and Wang, 2005). However, this is related to the presence and temperature of open water. If the open water season extends into November and December, these months may become foggier. November and December typically have many more days of blowing snow than July to September (which have none) and October (which averaged only 3\% between 1953 and 2004). This suggests a higher risk of operation disruption from blowing snow in November and December, though the magnitude of this risk is hard to quantify.

According to Gachon et al. (2011) November and December averaged slightly fewer storms with slightly lower average lengths and intensities between 1980 and 2009 than the month of October. While climate models do not project any change in November storminess, they do project moderate increases in the number and residence time of storms in December by the year 2070 (Savard et al., 2014). Thus at present storms would likely not disrupt shipping in November or December any more than they do now in October, and according to current projections this is unlikely to change for some period of time. 


\section{- Shipping earlier in July}

Wind conditions in Churchill in July are likely less challenging than conditions in the other months of the shipping season. Between 1991 to 2014, July averaged the lowest number of days with winds reaching speeds greater than every threshold above $30 \mathrm{~km} \mathrm{~h}^{-1}$ (Table 6.4, page 77). Furthermore, a comparison of the 1991-2011 and the 1970-1991 averages for July suggests only a relatively moderate increase in the number of days with strong winds per month (Table 6.5, page 79). Taken together, wind conditions in July both at present and in the future are likely to be favourable for shipping operations at the Port of Churchill.

The month of July also averaged a relatively high percentage of days without precipitation between 1991 and 2011 (53\%). Only November averaged more days without precipitation amongst months of the shipping season (Table 6.6; page 80). However, the proportion of days in July without precipitation declined significantly from 1970 to 2011 at a rate of -0.028 (or-2.8\%) per decade. This trend corresponds to a loss of roughly 3.8 days without precipitation from 1970 to 2011. The proportion of days with relatively high precipitation (1 $\mathrm{mm}$ and upwards) also appeared to rise in July during that timeframe. In summary, July's 1991-2011 precipitation conditions are amongst the most favourable for shipping operations but current trends suggest that precipitation disruption of operations may become more common in July in the future. It is not clear when, or if, rain conditions in July might become as challenging as those in months such as August or September.

\subsubsection{Increased re-supply activity}

As described in Section 3.2 of the introduction, the Port of Churchill's current re-supply operations typically consist of about 3 to 4 shipments per year, totalling roughly 10,000 tonnes destined for the Kivalliq region. Re-supply shipping through the Port is currently conducted by Nunavut Sealink \& Supply Inc. and extends from mid-July to late-October (F. Gaudreau, personal communication, March 20,2015). Current and projected environmental and economic conditions in the Hudson Bay Complex are highly favourable for an expansion of the Port of Churchill's re-supply activity.

From an economic perspective, Nunavut and the area of Kivalliq are experiencing rapid development and growth in the housing and industry sectors. Millions of dollars have been invested in the area and many new mineral extraction projects are at various stages of development (Meredith and Norquay, 2013). Nunavut Sealink \& Supply Inc.'s current contract with the Government of Nunavut only calls for the shipment of cargo from Churchill to the Kivalliq area, and at present shipment requirements are met with the 3 to 4 sailings each year $(F$. Gaudreau, personal communication, March 20, 2015). However, marine re-supply demand in Kivalliq could grow or re-supply shipping from the Port of Churchill could expand to service communities and industry beyond the Kivalliq area. With regard to Port stakeholders, both $\mathrm{J}$. McEachern and E. Vido believe that re-supply activity through the Port of Churchill will grow by 2030 and 2050 (J. McEachern, personal communication, November 18, 2014; E. Vido, 
personal communication, February 24, 2015). Expansion of marine re-supply in the Complex seems quite probable when one also considers the trends towards longer open water seasons throughout the Complex.

There is enormous potential for the communities and projects in the Hudson Bay Complex to source a higher proportion of their required materials from marine rather than air re-supply, a much cheaper alternative. With its strategic location, the Port of Churchill may be well placed to play a key role in this growth in re-supply shipping.

\subsubsection{Next Steps}

Further development in two areas of Arctic science in particular could help achieve the realization of a longer shipping season for the Port of Churchill by 2030 or 2050 . This would occur in partnership with the Port of Churchill stakeholders' efforts to reduce the constraints on shipping season imposed by shipping policy and insurance regulations.

1. Further scientific evidence of a longer and lengthening open water season along the Port's shipping route.

This document has brought together the most recent data surrounding sea ice timing in the Hudson Bay Complex. While this document does provide compelling evidence that the open water season along the Port of Churchill's shipping route has lengthened and will further lengthen in the future, these things could be yet more firmly established with more scientific analysis. Useful research might include sea ice projections with a higher resolution and a higher degree of confidence.

2. Improved sea ice forecasting.

Marine shippers rely on ice reports and forecasts in order to navigate safely in Arctic waters. The Canadian Ice Service (CIS) provides these services for the waters of the Hudson Bay Complex and the rest of the Canadian Arctic. The CIS provides daily forecasts that map the ice edge and provide warnings in circumstances where ice is particularly hazardous to shipping (Canadian Ice Service, 2015). The CIS also provides 30-day forecasts "which describe the general advance or retreat of ice in a region over a 30-day period" (Canadian Ice Service, 2015). Finally, the CIS additionally provides a seasonal outlook, typically in June, which presents the Ice Service's estimate for the timing of that summer's sea ice breakup in the Canadian Arctic (Canadian Ice Service, 2015).

While there is no doubt that the freeze-up and breakup of sea ice are based on an extremely complex mix of factors, further scientific advancement in the field of sea ice forecasting may nonetheless allow for a usefully accurate prediction of the open-water season available to the Port of Churchill before the shipping season actually begins. Longer timeframe ice forecasting skill has been improving in recent years (Tivy et al., 2011). Hochheim and Barber (2014) examined the relationships between seasonal surface air temperatures, winds, and sea ice extent. Their results suggest correlations that could at some point be used to forecast ice conditions perhaps as much as 6-8 months into the future. Tivy et al (2011) examined the accuracy of ice 
predictions for Hudson Bay over various time frames made using various "predictands" (iceinfluencing factors). The authors report noteworthy progress in the ability to predict ice conditions in July based on fall measurements (Tivy et al., 2011).

\subsection{The Hudson Bay Complex's Ecological Vulnerabilities to Shipping Activity: a Brief Overview}

7.4.1. The pathways of effects for shipping and port operations

7.4.2. Pollution.

7.4.3. Disturbance of Marine Mammals

7.4.4. Introduction of invasive species

A literature review guided by the Department of Fisheries and Ocean's shipping Pathways of Effects (POE) method of ecological assessment (described below) was used to examine the Hudson Bay Complex's ecological vulnerabilities to shipping activity. The results of this literature review, presented below, provide a rough idea of the Port of Churchill's potential impacts on the environment of the Hudson Bay Complex. The discussion below is relatively brief and largely theoretical. It is our hope that a suitable party will complete a comprehensive, hands-on risk assessment of shipping in the Hudson Bay Complex in the near future.

\subsubsection{The Pathways of Effects for Shipping and Port Operations}

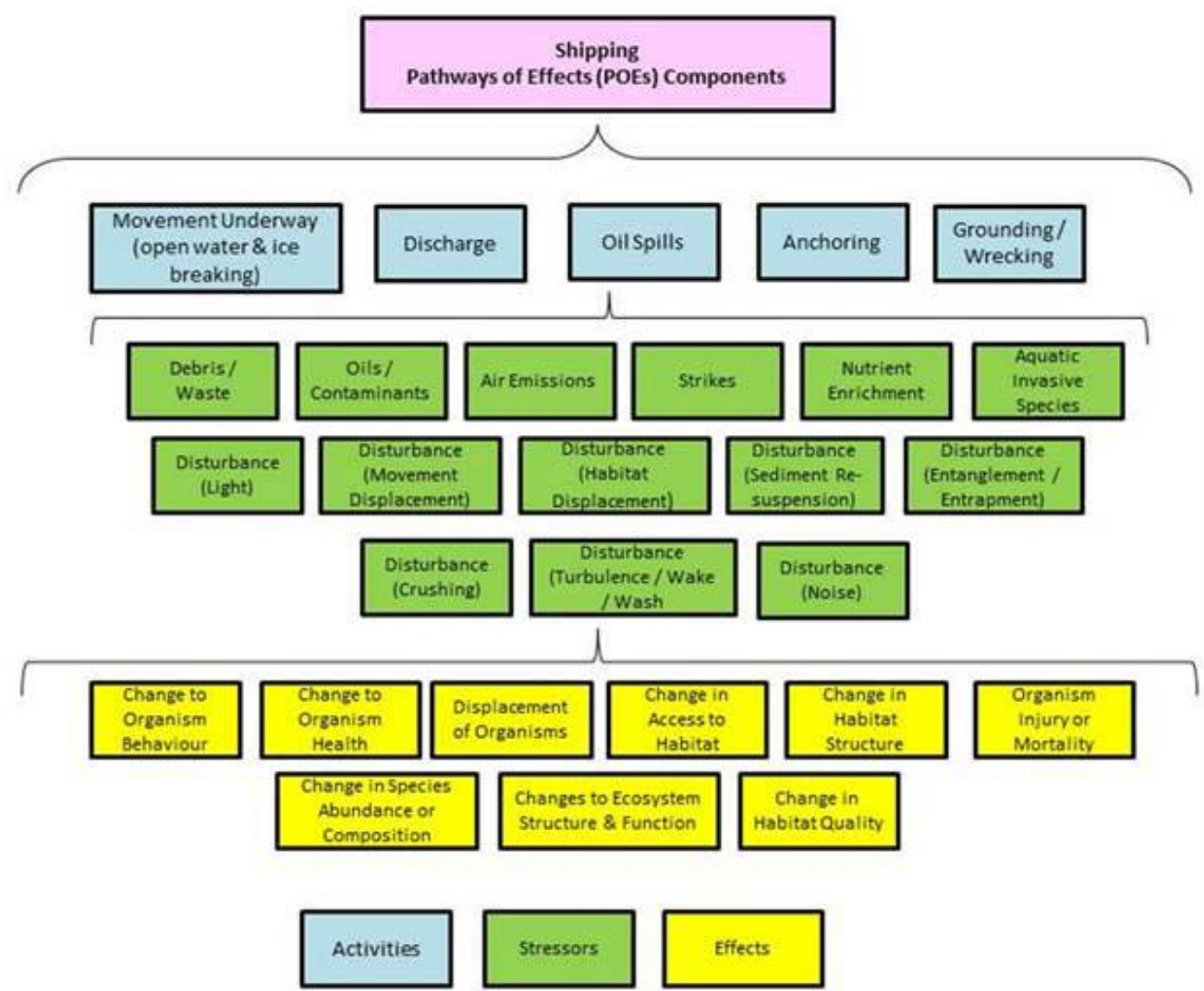

Figure 7.2: The Pathways of Effects (POE) for shipping according to the Department of Fisheries and Oceans' POE assessment model (CSAS, 2014b). 
Shipping and port operations can interact with the natural environment in many different ways (CSAS 2014b; CSAS 2014c). The Department of Fisheries and Ocean's Pathways of Effects (POE) method of ecological assessment provides a useful framework for considering the ecological consequences of the Port of Churchill's shipping and port operations. In the POE method, an undertaking such as shipping is broken down into its various components, or "activities", and the ecological "stressors" and consequent "effects" of each activity are then examined (CSAS, 2014b). The DFO's Pathways of Effects (POEs) for shipping are shown in Figure 7.2 while the POEs for Port Construction and Operation are shown in Figure 7.3:

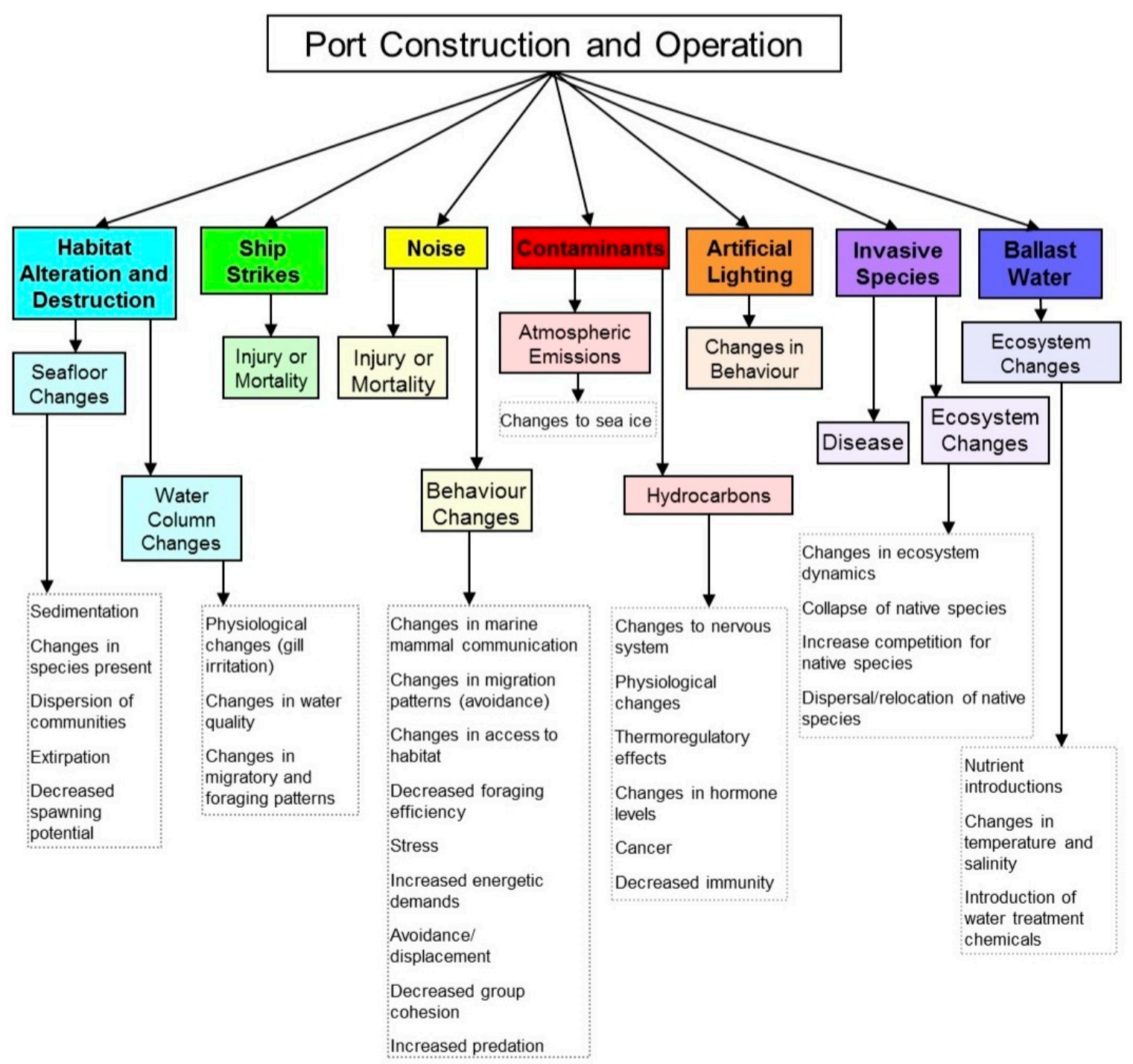

Figure 7.3: The Pathways of Effects (POE) for Port Construction and Operation according to the Department of Fisheries and Oceans' POE assessment model (CSAS, 2014c).

We chose to divide some of the ecological stressors of the Port of Churchill's shipping and port operations into three groups for the sake of further discussion. These three groups are: pollution, disturbance of marine mammals, and species introductions (aquatic invasive species). Note that 
not all of the stressors and effects of shipping and port operation are included in the discussion below.

\subsubsection{Pollution}

Shipping can generate pollution through operation-associated discharge of contaminants or through accident-associated spills or wrecking.

\section{- Operation-associated discharge of contaminants}

A DFO risk assessment for Darnley Bay in the Beaufort determined that shipping vessels and port operations could pollute marine waters through the discharge of anti-foulants and hydrocarbons $(C S A S, 2014 \mathrm{c})$. In a worst-case scenario, anti-foulant toxicity can result in poisoning, immunosuppression, cancer, and other health effects in marine organisms (CSAS, 2014c). Hydrocarbon toxicity can cause nervous system and physiological changes, immunosuppresion, cancer, and other health effects (CSAS, 2014c). The likelihood of discharge and the scale of the consequent effects were not discussed in the DFO risk assessment.

\section{* Large-scale discharge of contaminants caused by shipping accident or wreckage.}

As outlined in the introductory sections of this document, the Port of Churchill currently ships grain and re-supply freight (which includes essentially everything except for perishable food). Re-supply freight does include fuel oil required by Kivalliq communities for industrial and residential use. Of all the freight leaving the Port of Churchill, an examination of the Hudson Bay Complex's vulnerability to an oil spill seems most pressing. This is partly because fuel oil is currently carried through re-supply operations, and partly because it is possible that oil will be shipped from the Port of Churchill on a much larger scale by 2030 or 2050.

In addition to oil, it is also possible that potash will be shipped out of the Port of Churchill by 2030 or 2050. No research could be found discussing the likelihood or ecological consequences of a potash spill in Arctic waters.

\section{- Oil spill vulnerability in the Hudson Bay Complex}

A significant oil spill in the Hudson Bay Complex would be a new experience for all parties involved in spill identification, clean up, and remediation. While extensive technologies, infrastructure, and response protocols have been developed to mitigate the risks and consequences of marine oil spills in temperate climes, an oil spill in Arctic waters represents a significantly different and poorly understood prospect (Barber et al., 2014).

Little is known about the behaviour of oil in ice-covered seawater. Industry and scientific knowledge to date is based on relatively limited laboratory research and a very small number of minor oil spills in Arctic conditions (Barber et al., 2014). Studies from this limited work have revealed that oil's behaviour changes significantly depending on the presence, concentration, and physical structure of sea ice (LOOKNorth, 2014).

The behaviour of oil in ice-free water is relatively well understood. Upon entering open water, oil undergoes changes in both chemical and physical properties through the many processes 
associated with weathering. Oil will evaporate, spread, emulsify, disperse, dissolve, degrade, and oxidize at variable rates depending on environmental conditions and the type of oil. Algorithms, technologies, and methods exist to help parties responding to an open-water spill target their response to match the current state and location of the oil (LOOKNorth, 2014).

The weathering and movement of oil in ice-covered waters is dependent on ice and snow conditions (Barber et al., 2014). In general, snow and ice tend to reduce weathering rates while the movement of oil is dependent on the concentration and physical structure of the ice, which can be highly variable (Barber et al., 2014). Figure 7.4 indicates some of the many ways that oil can behave in ice-covered water. These processes are not well understood and have not been thoroughly studied. Currently, there is no reliable way to predict just how oil will behave in a given snow and ice scenario (Barber et al., 2014).

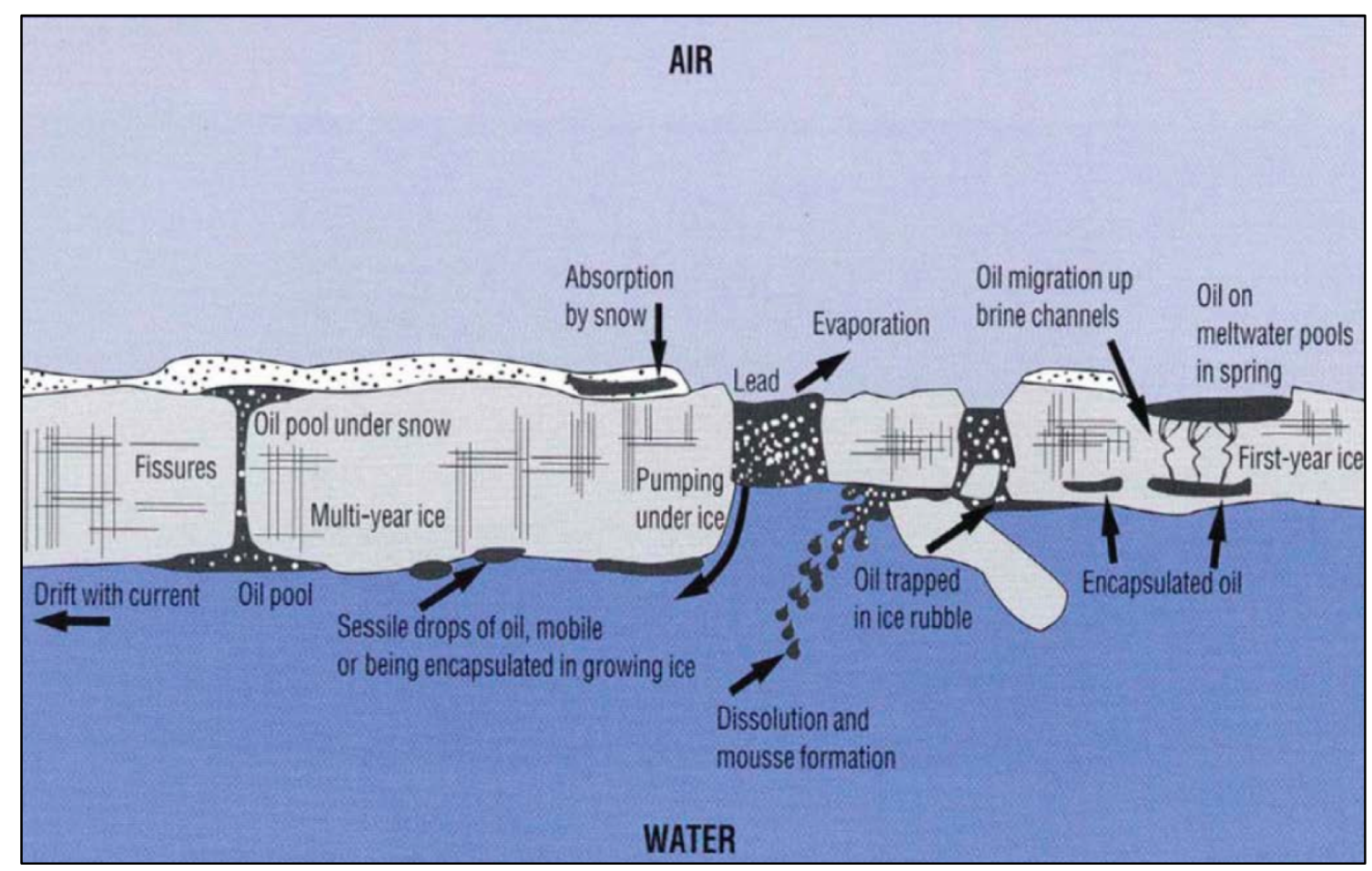

Figure 7.4: Different ways oil can behave in ice-covered waters (Allen 2008; Adapted from Bobra and Fingas, 1986)

Not only is oil's behaviour in ice-covered waters unpredictable, there is also no clear strategy for detecting oil trapped under or within the ice cover. Most detection techniques used in open water are inapplicable, ineffective, or untested in Arctic environments (Barber et al., 2014). This is also true for the remediation and recapture methods used in open water (LOOKNorth, 2014). Finally, the response of Arctic organisms and ecosystems exposed to oil toxicity are largely unknown (Barber et al., 2014).

Our poor understanding of oil's behaviour in ice-covered waters is not the only cause for special concern about oil spills in Arctic waters. There is also appears to be limited oil response capacity in the area. The Canadian Coast Guard (CCG) is in charge of oil spill monitoring and response 
within the Hudson Bay Complex; however it has been suggested that the CCG is poorly equipped to mount even a small-scale operation in the Complex (Goegebeur 2014). The CCG does maintain pollution response kits in 17 communities throughout Nunavut but these kits are designed only for response to small coastal or land-based spills, such as those that could arise through re-supply operations (LOOKNorth, 2014).

Re-supply ships carrying fuel oil from the Port of Churchill travel through the ecologically and biologically significant areas of the Southwestern Hudson Bay Estuaries and the Western Hudson Bay Coastline. If oil is shipped through the Port of Churchill on a large scale, tankers could travel through the two Hudson Strait EBSAs and the Southwestern Hudson Bay Estuaries EBSA (Figure 5.1, page 34). These are ecologically sensitive areas with an abundance of culturally and biologically important species and habitats (described in the "Ecology of the Hudson Bay Complex" section). These areas could be highly vulnerable to oil spills, especially when the lack of response capability in the area and our poor understanding of oil's behaviour in ice-covered waters are taken into consideration. This sentiment was echoed by Chatham House researchers in a 2012 assessment of opportunities and risk in the Arctic: "the potential environmental consequences, difficulty and cost of clean-up may be significantly greater in the Arctic than in other extreme environments" (Emmerson and Lahn, 2012).

\subsubsection{Disturbance of Marine Mammals}

According to a literature review, the Port of Churchill's shipping operations could directly impact marine mammals in several ways: a significant spill of contaminant could result in death or other negative health effects, ship strikes could cause injury or mortality, and the noise and disturbance of the Port and moving vessels could cause negative behavioural changes.

Recall that the marine mammals of the Hudson Bay Complex include Bowhead Whale, Killer Whale, Beluga Whale, Narwhal, Walrus, Ringed Seal, Harbour Seal, Bearded Seal, Harp Seal, and Hooded Seal (Stephenson and Hartwig, 2010).

\section{Ship strikes: Belugas in the Churchill River Estuary}

We hypothesize that the most likely location for ship strikes to occur is within and nearby the Churchill River estuary during the summer months. This is because Belugas aggregate in the estuary from mid-June until the end of August and there can be extremely high densities of whales (Stewart and Lockhart, 2005). This aggregation coincides with the early part of the Port's shipping season. Fortunately, Belugas are quite mobile animals and the risk of ship strike is lower than with larger whale species (Norman, 2011). Nonetheless, ship strikes are a possibility and could become more frequent if shipping traffic in the estuary during the summer months increases over time.

Ship strikes are not the only potential disturbance for Belugas in the Churchill River estuary. Belugas are sensitive to hydrology (e.g. depth and current speed) and chemistry, and changes in these variables may influence the suitability of a habitat (Lawson \& Lesage, 2013). A negative

change in the habitat quality could have major consequences for the Beluga population using the 
area, as the estuary is a particularly important habitat for these whales; the Churchill estuary is used as a relatively safe area for moulting and birthing (Stewart and Lockhart, 2005).

\section{* The effects of noise disturbance}

Shipping noise can cause many behavioural changes in marine mammals. Noise can influence communication, migration patterns, foraging efficiency, stress levels, and energy requirements, to name a few effects $(C S A S, 2014 \mathrm{c})$. Whales often choose to move away from vessels and the noise they produce (Norman, 2011). This would suggest that the movement patterns of migrating or resident whales in Hudson Bay or Hudson Straight could be affected by vessels travelling to and from the Port. There is also evidence that exposure to low-frequency ship noise may be associated with chronic stress in whales in heavy ship traffic areas (Rolland et al. 2012, Lawson \& Lesage, 2013). This may be relevant to whales in Hudson Strait, one of the areas with the highest traffic density in the Canadian Arctic, or to whales near the Port of Churchill. It is also possible that Belugas using the Churchill River estuary are affected by noise from the Port of Churchill's operations.

Belugas are likely the best studied whale species in the Hudson Bay Complex. It has been suggested that Beluga exhibit a strong reaction to approaching vessels. In one case, Belugas were observed travelling a distance of 35 to $50 \mathrm{~km}$ to move away from an icebreaker, and the animals did not return to the area for several days (Finley et al., 1990, Lawson and Lesage, 2013). Conversely in Manitoba's 2016 Beluga Habitat Sustainability Plan it is suggested that Belugas may habituate to regularly occurring noise. Ultimately, the authors of the Beluga Habitat Sustainability Plan found noise to be a 'Medium' level of concern for the Western Hudson Bay Beluga population (Manitoba Western Hudson Bay Ad Hoc Beluga Habitat Sustainability Plan Committee, 2016).

\subsubsection{Introduction of invasive species}

Shipping vessels often transport aquatic species either in ballast water or simply attached to the vessel's hull. This can sometimes result in the introduction of non-indigenous species when a vessel travels into a new area, despite the presence of regulations designed to minimize the occurrence of such events (CSAS, 2012). We should note that a species introduction is not assured simply because an organism of a foreign species is released into a new environment. Upon arrival, the organism must both survive and propagate in order to truly be "introduced". Once introduced, new species can have a variety of effects on their environment. While many introduced species may have relatively little effect, others may have severe negative consequences for an ecosystem. Under the latter scenario the introduced species is termed an "invasive species" (CSAS, 2012). Invasive species can cause a plethora of changes of varying magnitude in an ecosystem, ranging from directly-caused disease and mortality of native species

to more subtle ecosystem changes initiated by competition, predation, or habitat alteration (CSAS, 2012). 
Shipping traffic travelling to and from the Port of Churchill passes through four Ecologically and Biologically Significant Areas (EBSAs) (Figure 5.1, page 34). The Port of Churchill itself is within the Southwest Hudson Bay Estuaries EBSA. Sensitive Arctic ecosystems such as these could be significantly impacted by invasive species (CSAS, 2012). In a risk assessment of shipmediated introduction of non-indigenous species to the Canadian Arctic, it was determined that the Port of Churchill is the Arctic port with the highest risk of environmental consequences from species introduction (CSAS, 2012). This is primarily to do with the relatively high volume of international shipping traffic travelling to the Port, but the Port's surrounding environment was also taken into consideration (CSAS, 2012). The risk of species introduction at the Port is projected to increase as traffic rises in the future and in 2012 it was recommended that a system be put in place to monitor and mitigate introduction risks (CSAS, 2012).

\section{Summary}

The Hudson Bay Complex is a diverse and sensitive environment with many areas and species of ecological, biological, and cultural importance. The ecology of the Complex is likely highly sensitive to the many stressors of shipping and shipping impacts will likely grow as climate change progresses, sea ice recedes, and shipping activity in the Complex increases. This is particularly true if the Port sees growth in international shipping and diversifies commodities to include the shipment of oil or other ecologically hazardous goods. At present, there appears to be an important and perhaps time-limited opportunity to take proactive action to try and protect the ecosystems of the Complex from the many potential ecological stressors of the area's present and future economic activity.

The issue of oil in ice infested waters is not limited to the Hudson Bay Complex. As the likelihood of offshore drilling activity increases and transportation corridors through the Arctic become increasingly passable for tanker vessels, the prospect of an oil spill in the Arctic is a concern for all northern nations and territories. In response to this issue, CEOS and several partners from academia, government, and industry will be developing a unique, highly innovative research facility in Churchill to study the many research questions surrounding oil in Arctic waters. This facility will be called the Churchill Marine Observatory (CMO) and more information on $\mathrm{CMO}$ can be found online (http://umanitoba.ca/ceos/research/CMO.html). 


\section{References}

Allen, A.A. (2008). Oil Spill Response Planning for Shell Shell's Offshore Exploration Program in s the Alaskan Beaufort Sea. Alaska Forum on the Environment, Anchorage, Alaska, February, 2008.

Barber, D. G., Rysgaard, S., Stern, G., Wang, F., Dmitrenko, I., Ehn, J., ... \& Pucko, M. (2014). Research Gaps in Scientific Understanding of Oil in Sea Ice. Submission to the Tanker Safety Expert Panel.

Bobra, A.M. and Fingas, M.F. (1986) “The Behaviour and Fate of Arctic Oil Spills”, Water Science and Technology, 18, pp. 13-23.

Canadian Coast Guard. (2015, April 16). Icebreaking Operations Directive 1: Provision of Icebreaking Services [website]. Retrieved from Government of Canada, Canadian Coast Guard website: http://www.ccggcc.gc.ca/eng/CCG/Ice_Home/Ice_Publications/Directive1-Icebreaking-Services

Canadian Environmental Assessment Agency (CEAA). (2011, December). Summary of the Environmental Impact Statement for the Canpotex Potash Export Terminal. Retrieved from the Government of Canada, Canadian Environmental Agency website: https://www.ceaa-acee.gc.ca/050/documents/53476/53476E.pdf

Canadian Ice Service (2015). Ice Bulletins (and Warnings) and Iceberg Bulletins. Retrieved from Government of Canada, Environment Canada website: https://www.ec.gc.ca/glacesice/default.asp?lang=En\&n=E568E9D7-1

Canadian Science Advisory Secretariat (CSAS). (2011, November). Identification of Ecologically and Biologically Significant Areas (EBSA) in the Canadian Arctic. Science Advisory Report 2011/055. Retrieved from the Government of Canada, Department of Fisheries and Oceans website: http://www.dfo-mpo.gc.ca/csas-sccs/Publications/SARAS/2011/2011_055-eng.html

Canadian Science Advisory Secretariat (CSAS). (2012,March). Science Advice from the Risk Assessment for Ship-mediated Introduction of Aquatic Nonindigenous Species to the Canadian Arctic. 2011/067. Retrieved from Government of Canada, Department of Fisheries and Oceans website: http://www.dfo-mpo.gc.ca/csassccs/Publications/ResDocs-DocRech/2011/2011_105-eng.html

Canadian Science Advisory Secretariat (CSAS). (2014a). Pilot Application of An Ecological Risk Assessment Framework to Inform Ecosystem-Based Management in the Pacific North Coast Integrated Management Area. Retrieved from the Government of Canada, Department of Fisheries and Oceans website: http://www.dfo-mpo.gc.ca/csassccs/publications/sar-as/2014/2014_026-eng.pdf

Canadian Science Advisory Secretariat (CSAS). (2014b). Shipping Pathways of Effects: An overview. Retrieved from the Government of Canada, Department of Fisheries and 
Oceans website: http://publications.gc.ca/collections/collection_2015/mpo-dfo/Fs70-62014-059-eng.pdf

Canadian Science Advisory Secretariat (CSAS). (2014c). Assessment of Stressors, Impacts and Pathways of Effects for the Darnley Bay Anuniaqvia Niqiqyuam Area of Interest for Marine Protected Area Designation. Retrieved from the Government of Canada, Department of Fisheries and Oceans website: http://www.dfo-mpo.gc.ca/csassccs/Publications/SAR-AS/2014/2014_002-eng.pdf

Emmerson and Lahn (2012). Arctic Opening: Opportunity and Risk in the High North. Chatham House for Lloyd's.

Environment Canada (2013a). Sea Ice Climatic Atlas for the Northern Canadian Waters 19812010 [webpage]. Retrieved from Government of Canada, Environment Canada website: https://www.ec.gc.ca/glaces-ice/default.asp?lang=En\&n=4B35305B$1 \&$ offset $=1 \&$ toc $=$ show

Environment Canada (2013b). Homogenized Surface Wind Speed Data [dataset]. Retrieved from Government of Canada, Environment Canada website: http://www.ec.gc.ca/dcchaahccd/default.asp?lang=en\&n=552AFB3E-1

Environment Canada (2013c). Adjusted Precipitation Data [dataset]. Retrieved from Government of Canada, Environment Canada website: http://www.ec.gc.ca/dcchaahccd/default.asp?lang=en\&n=9AA530BE-1

Finley, K.J., Miller, G.W., Davis, R.A., and Greene Jr., C.R. 1990. Reactions of belugas, (Delphinapterus leucas) and narwhals (Monodon monoceros) to ice-breaking ships in the Canadian high arctic. Can. Bull. Fish. Aquat. Sci. 224: 97-117.

Gachon, P., Aider, R., Martin, P., Saad, C., Gagnon, S., Cotnoir, A. (2011). Storm tracks activities over the Hudson Bay area and links with surface extremes: past and future changes [Presentation slides]. Retrieved from: www.drinetwork.ca/extremes2011/gachon.pdf

Goegebeur, B. (2014, November). Canadian Arctic Search and Rescue: An Assessment. University of Ottawa: Research papers from the Faculty of Social Sciences. Retrieved from: https://www.ruor.uottawa.ca/handle/10393/31976

Hanesiak, J.M., X.L. Wang (2005). Adverse-weather trends in the Canadian Arctic, J. Climate, $18,3140-3156$.

Hochheim, K. P., \& Barber, D. G. (2014). An update on the ice climatology of the Hudson Bay system. Arctic, Antarctic, and Alpine Research, 46(1), 66-83. doi:10.1657/1938-424646.1 .66

Joly, S., Senneville, S., Caya, D., \& Saucier, F. (2011). Sensitivity of Hudson Bay sea ice and ocean climate to atmospheric temperature forcing. Climate Dynamics, 36(9-10), 18351849. 
Lawson, J.W. and Lesage, V. (2012). A draft framework to quantify and cumulate risks of impacts from large development projects for marine mammal populations: A case study using shipping associated with the Mary River Iron Mine project. Canadian Science Advisory Secretaraiat (CSAS). Retrieved from the Government of Canada, Department of Fisheries and Oceans website: http://www.dfo-mpo.gc.ca/Library/348009.pdf

LOOKNorth. (2014, May). Oil Spill Detection and Modeling in the Hudson and Davis Straits. Final Report. LOOKNorth report R-13-087-1096 v2.0.

Manitoba Western Hudson Bay Ad Hoc Beluga Habitat Sustainability Plan Committee. 2016. Manitoba's Beluga Habitat Sustainability Plan. Manitoba Conservation and Water Stewardship. Winnipeg, Manitoba. 30pp. Retrieved from https://gov.mb.ca/conservation/wildlife/belugahabitat.html

Meredith, D., \& Norquay, D. (2013, January). Federal-Provincial Task Force on the Future of Churchill, Retrieved from the Government of Manitoba, Manitoba Infrastructure and Transportation website: https://www.gov.mb.ca/mit/pdf/churchill.pdf

Minister of Justice. (1985). Arctic Waters Pollution Prevention Act - Shipping Safety Control Zones Order. Retrieved from Department of Justice, Justice Laws website: http://lawslois.justice.gc.ca/eng/acts/A-12/

Norman, S. A. (2011). Nonlethal anthropogenic and environmental stressors in Cook Inlet beluga whales (Delphinapterus leucas). Report prepared for NOAA Fisheries, National Marine Fisheries Service, Anchorage, Alaska. NMFS contract no. HA133F-10-SE-3639. 113 p.

Office of the Auditor General of Canada. (2014, Fall). Report of the Commissioner of the Environment and Sustainable Development - Chapter 3: Marine Navigation in the Canadian Arctic. Retrieved from http://www.oagbvg.gc.ca/internet/English/parl_cesd_201410_03_e_39850.html

Rolland, R. M., Parks, S. E., Hunt, K. E., Castellote, M., Corkeron, P. J., Nowacek, D. P., ... \& Kraus, S. D. (2012). Evidence that ship noise increases stress in right whales. Proceedings of the Royal Society of London B: Biological Sciences, rspb20112429.

Savard, J-P., Gachon, P., Rosu, C., Aider, R., Martin, P., Saad, C. (2014, October). Impact des changements climatiques sur le régime des tempêtes, les niveaux d'eau et les vagues dans le Nunavik. Retrieved from: www.ouranos.ca/media/publication/357_RapportSavard2014.pdf

Steiner, N., Azetsu-Scott, K., Galbraith, P., Hamilton, J., Hedges, K., Hu, X., . . ., van der Baaren, A. (2013). Climate Change Assessment in the Arctic Basin Part 1: Trends and Projections - A Contribution to the Aquatic Climate Change Adaptation Services Program. Retrieved from Government of Canada, Department of Fisheries and Oceans website: http://www.dfo-mpo.gc.ca/library/350169.pdf

Stephenson, S.A., and Hartwig, L. (2010). The Arctic Marine Workshop. Freshwater Institute, Winnipeg, Manitoba, February 16-17, 2010. Can. Manuscript Rep. Fish. Aquat. Sci. 
2934: vi+67p. Retrieved from Government of Canada, Department of Fisheries and Oceans website: http://publications.gc.ca/site/eng/380744/publication.html

Stewart, D.B., \& Lockhart, W.L. (2005). An Overview of the Hudson Bay Marine Ecosystem. Retrieved from Government of Canada, Department of Fisheries and Oceans website: http://www.dfo-mpo.gc.ca/libraries-bibliotheques/toc-tdm/314704-eng.htm

Tivy, A., Howell, S. E., Alt, B., Yackel, J. J., \& Carrieres, T. (2011). Origins and levels of seasonal forecast skill for sea ice in Hudson Bay using Canonical Correlation Analysis. Journal of Climate, 24(5), 1378-1395. 


\section{Section D: Appendix}

\section{Appendix A: Glossary of Terms:}

- Albedo: A non-dimensional, unit-less measure of how well a surface reflects solar energy.

- Anomaly: An anomaly is a deviation from the norm. In climate science, anomalies are often computed by calculating long-term averages (the "norm") and then calculating an anomaly value for each year. This is done by taking each year's data value and subtracting the value of the average. As a result, positive anomaly values indicate years above the norm while negative values indicate years below.

- Climatology: In this document, the word climatology is used to describe the historical or "typical" characteristics of an environmental variable (usually referring to temperature). For example, the seasonal climatology of the Hudson Bay Complex (figure 6.1) describes the average seasonal temperatures from recent history.

- Hindcasts: Model-generated estimates for meteorological conditions in the past, rather than the future.

- Isostatic rebound: A geological process wherein land that was depressed by the weight of ice during a period of glaciation (e.g. the most recent ice age) rises very slowly once freed of that weight. Isostatic rebound is currently causing land to rise across a broad expanse of Canada, including the Hudson Bay region.

- Landfast ice: Ice that is fastened or anchored to the sea shore or sea bottom.

- Leads: Linear areas of open water where the ice cover has fractured and separated.

- Polynya: An area of open water surrounded by sea ice that forms in response to local wind or temperature forces.

- Reanalysis Data: Reanalysis datasets combine available, in situ, observations (e.g. weather station measurements) with climate model simulations to provide projections for various meteorological variables. The models effectively use real-world measurements for calibration. Reanalysis data sets allow for projections beyond the time or geographic scale covered by the real-world measurements.

- Sea ice: Frozen ocean water that forms, grows and melts in the ocean. Can be landfast or mobile within the pack ice.

- Sea ice dynamics: The motion of sea ice floes under atmospheric, oceanic, coriolis, sea surface tilt, and internal forces. If the forces acting on an ice floe are greater than the strength of the ice pack, the ice floes will deform through either ridging or rafting processes.

- Significant: When used in the discussion of results from scientific analysis, the word "significant" is only applied in cases of statistical significance. Results are only "statistically significant" when their calculation has occurred with a specified measure of statistical confidence (often $p<0.05$ at the $95 \%$ confidence level).

- Trend: In this document, a trend is a statistically significant change over time 